Florida International University

FIU Digital Commons

$11-4-2020$

\title{
Modernización y espacio urbano: el protagonismo de la ciudad en la literatura latinoamericana de fin de siglo (1880-1920)
}

\author{
Gabriela Carolina Escobar Rodríguez \\ Florida International University, gesco016@fiu.edu
}

Follow this and additional works at: https://digitalcommons.fiu.edu/etd

Part of the Latin American Languages and Societies Commons, Latin American Literature Commons, and the Modern Literature Commons

\section{Recommended Citation}

Escobar Rodríguez, Gabriela Carolina, "Modernización y espacio urbano: el protagonismo de la ciudad en la literatura latinoamericana de fin de siglo (1880-1920)" (2020). FIU Electronic Theses and Dissertations. 4579.

https://digitalcommons.fiu.edu/etd/4579

This work is brought to you for free and open access by the University Graduate School at FIU Digital Commons. It has been accepted for inclusion in FIU Electronic Theses and Dissertations by an authorized administrator of FIU Digital Commons. For more information, please contact dcc@fiu.edu. 


\section{FLORIDA INTERNATIONAL UNIVERSITY \\ Miami, Florida}

A dissertation submitted in partial fulfillment

of the requirements for the degree of

DOCTOR IN PHILOSOPHY

in

SPANISH

by

Gabriela Carolina Escobar Rodríguez 
To: Dean John F. Stack, Jr.

Steven F. Green School of International and Public Affairs

This dissertation, written by Gabriela Carolina Escobar Rodríguez, and entitled Modernización y espacio urbano: el protagonismo de la ciudad en la literatura latinoamericana de fin de siglo (1880-1920), having been approved in respect to style and intellectual content, is referred to you for judgement.

We have read this dissertation and recommend that it be approved.

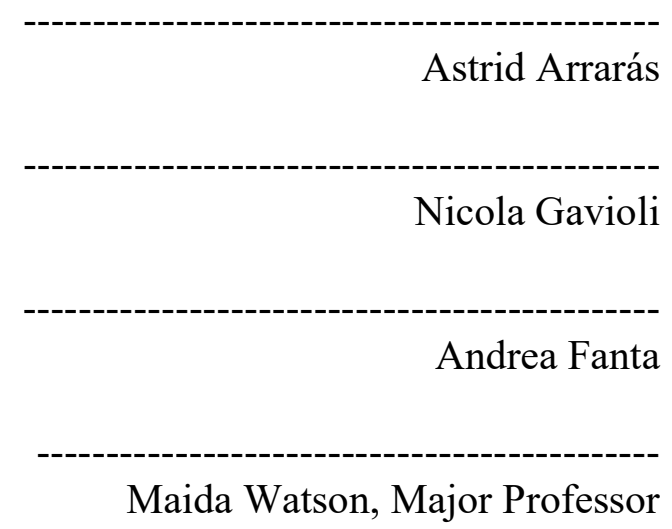

Date of defense: November 4, 2020

The dissertation of Gabriela Carolina Escobar Rodríguez is approved.

Dean John F. Stack, Jr. Steven J. Green School of International and Public Affairs

Andrés G. Gil Vice President for Research and Economic Development and Dean of the University Graduate School

Florida International University, 2020 
(C) Copyright 2020 by Gabriela Carolina Escobar Rodríguez

All rights reserved. 


\section{DEDICATORIA}

A los cinco incondicionales que han estado siempre a mi lado y que han hecho tanto posible: mi mamá, mi papá, mi hermano, mi esposo y mi tío Elle. 


\section{AGRADECIMIENTOS}

En primer lugar, quiero agradecer a los miembros de mi comité de tesis. A la Dra. Astrid Arrarás por sus amables palabras de ánimo; a la Dra. Andrea Fanta por su paciencia, por su tiempo, por compartir sus libros conmigo y por sus consejos siempre acertados y al Dr. Nicola Gavioli por creer en este proyecto y unirse a él cuando ya estaba comenzado. También me gustaría agradecer al Dr. Joan Torres-Pou, quien formó parte de este comité en las etapas iniciales de este estudio, y que siempre fue generoso con su tiempo y con sus conocimientos. Finalmente, quiero mostrar mi infinito agradecimiento a la directora de esta tesis, la Dra. Maida Watson, quien me ha apoyado de forma continua e incondicional desde mi llegada a Estados Unidos.

Asimismo, doy las gracias a Jaqueline Dipp y a la Dra. María Asunción Gómez, quienes me ayudaron incansablemente, y a pesar de los muchos tropiezos, a concretar mi entrada el programa de español. También agradezco al Departamento de Lenguas Modernas y a la Escuela de Postgrado de Florida International University (FIU) por el otorgamiento de las siguientes becas y apoyos que me permitieron completar esta investigación e, incluso, compartir parte de ella en conferencias nacionales e internacionales: Doctor Year Fellowship (DYF), Doctoral Evidence Acquisition Fellowsip (DEA) y Anita Broad Research Fellowship Award.

Por último, mi agradecimiento va a las personas que han estado a mi lado en distintas etapas de mi vida y que me han traído hasta donde estoy ahora. A mis compañeros de diferentes ciclos académicos, los de aquí y los de allá, los de FIU, las del Mater y los de la UCAB, gracias por compartir conmigo el camino, las penas y las alegrías, el tiempo, los apuntes, la información, los libros y tantos momentos. A los pilares de mi vida, mi mamá, 
mi papá, mi hermano, mi esposo y mi tío José Ángel (quien además leyó y corrigió este texto, y tantos otros, desde el comienzo), gracias por la presencia incondicional, la paciencia ilimitada y el cariño desmedido. Sin ustedes no hubiese llegado hasta aquí y este proyecto no se hubiese materializado. Al resto de mi familia y a mi círculo de amistades, gracias por los buenos deseos y por estar presentes.

A todos, de corazón, gracias. 


\begin{abstract}
OF THE DISSERTATION
MODERNIZACIÓN Y ESPACIO URBANO: EL PROTAGONISMO DE LA CIUDAD

EN LA LITERATURA LATINOAMERICANA DE FIN DE SIGLO (1880-1920)
\end{abstract}

by

Gabriela Carolina Escobar Rodríguez

Florida International University, 2020

Miami, Florida

\title{
Professor Maida Watson, Major Professor
}

Urban space has played a prominent role in late nineteenth century and early twentieth century Latin American literature and culture due to the historical and political importance that cities have had and to the relevant role they played in the passage of LatinAmerican to modernity at the end of the nineteenth century. As Christopher Conway points out: "Nineteenth-century Spanish American cultural and political history was defined by the desire to become modern, we could argue that cities embodied modernization better than any other idea or place" (23). In spite of this, the fin de siècle's city novels have not received the attention they deserve. They have often been misclassified (the Latin American urban novel has been studied almost exclusively as a phenomenon of the second half of the 20th century) and/or ignored even though they could provide crucial information about the modernization of Latin American capitals and the development of national identity in the region, as well as on the birth of urban literature in Latin America.

Through the physical image of the city, liberal politicians and intellectuals of the 19th century tried to restructure the national identity using idealized European models that often clashed with the traditional aspects considered by a sector of society as the true Latin 
American traits. This tense situation was further complicated by the complex relationship that the newly founded republics had with the indigenous cultures of each area. The urban novel of the late nineteenth and early twentieth centuries questioned or rejected the proposed idea of modernity and nation and tried, in some cases, to negotiate new possibilities of identity. In this dissertation I analyze the literary representation of the Latin American city in six urban novels from Mexico, Argentina and Venezuela published between 1880 and 1920 with the purpose of identifying the tensions that the modernizing process produced in the urban space, its inhabitants (and their way of life) and the concept of nation of each country. 


\section{ÍNDICE}

CAPÍTULO

PÁGINA

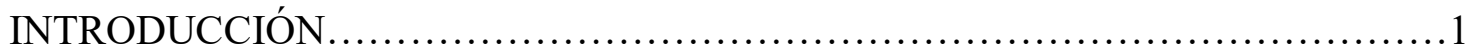

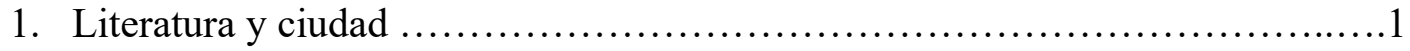

2. Hipótesis y consideraciones a modo de preámbulo..........................6

3. Estado de la cuestión y objetivos de la investigación...........................9

4. Fuentes teóricas y metodología.............................................12

5. División del trabajo y resumen de contenidos.................................14

6. Breves consideraciones acerca del contexto social y literario...................17

CAPÍTULO I: La ciudad como espacio evaluado y evaluador en el cuadro de

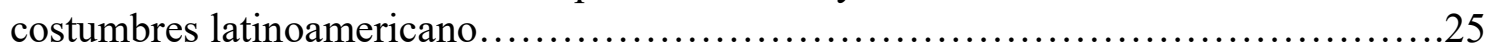

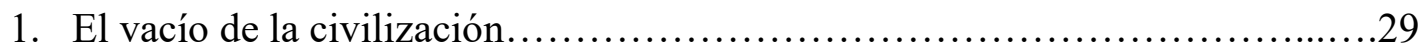

2. "El emporio de las letras": la ciudad como paradigma de la civilización..........37

3. Ciudad, tradición y modernidad.............................................46

4. Conclusión: la dimensión literaria de la experiencia urbana......................59

CAPÍTULO II: Entre la ansiedad y el cuestionamiento: cambios urbanos, nueva fauna citadina y crisis de valores en La gran aldea de Lucio Vicente López y Todo un pueblo de Miguel Eduardo Pardo. ....

1. La gran aldea: la ciudad y la novela de costumbres..........................64

2. Todo un pueblo: la novela de ciudad naturalista...............................80

3. Conclusión: La superficialidad de la modernidad y la ciudad a través de un

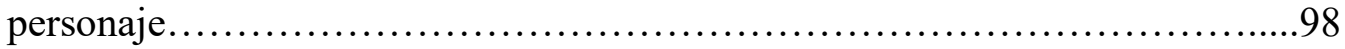

CAPÍTULO III: La urbe, los ciudadanos y las novelas de (de)formación: el caso de Ídolos rotos de Manuel Díaz Rodríguez y Santa de Federico Gamboa..................102

1. Ídolos rotos: el Künstlerroman urbano y el fracaso del artista....................105

2. Santa: ¿Novela de (de)formación o Bildungsroman fracasado?.........................123

3. Conclusión: Las contradicciones de la modernidad a través de la experiencia urbana del individuo y su devenir como ciudadano moderno.

CAPÍTULO IV: Delincuencia y criminales: la ciudad subalterna y la otredad urbana en La rumba de Ángel de Campo y El conventillo de Luis Pascarella.....................149

1. La rumba: la urbe y el discurso criminológico................................153

2. El conventillo: ciudad e inmigración....................................167

3. Conclusión: el orden urbano y el sistema punitivo..........................186

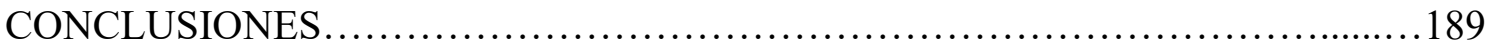

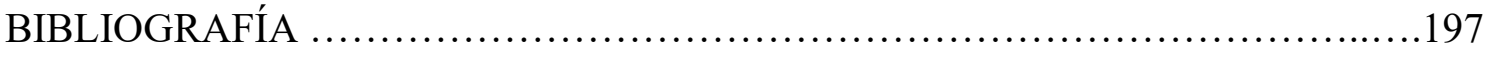

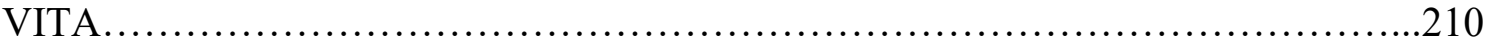




\section{INTRODUCCIÓN}

\section{Literatura y ciudad}

En 1867 el escritor peruano de cuadros de costumbres Manuel Atanasio Fuentes especificó, en el prólogo de su obra Lima, apuntes históricos, descriptivos, estadísticos y de costumbres, que escribía sobre Lima porque: "no merecemos ser juzgados como rudos habitantes de las selvas, semi-cubiertos de plumas que reciben á flechazos á los huespedes que llegan á sus chozas para devorarlos después, crudos, en un banquete de familia" (XIIIIX). ${ }^{1}$ Casi trece décadas más tarde, en 1996, los chilenos Alberto Fuguet y Sergio Gómez señalaron en la Presentación del país McOndo, texto que prologa la compilación de cuentos que lleva el mismo nombre: "vender un continente rural cuando, la verdad de las cosas es urbano (más allá que sus sobrepobladas ciudades son un caos y no funcionen) nos parece aberrante, cómodo e inmoral" (18). Casi un siglo y medio separa la publicación de estos textos; no obstante, el argumento de los tres escritores es el mismo: a su modo de ver, Latinoamérica era y es un continente predominantemente urbano y es importante que el mundo lo sepa y lo identifique como tal. Como se desprende de este par de ejemplos, los siglos XIX y XX cerraron con la misma preocupación.

Para finales de la segunda década del siglo XXI, la estadística de la población urbana en Latinoamérica y en Estados Unidos era la misma: el 80\% vive en zonas urbanas (Castells-Quintana s/p, Ingraham s/p). ${ }^{2}$ Por otro lado, las listas de las 25 ciudades con más

\footnotetext{
${ }^{1}$ Conservo en todas las citas textuales de este estudio la grafía y puntación original de los textos y ediciones citadas.

${ }^{2}$ Existen, por supuesto, ciertas diferencias. Estados Unidos es un país mucho más grande que la mayoría de los países latinoamericanos (exceptuando Brasil). Ese $80 \%$ de población urbana está subdividida en diversas ciudades mientras que en Latinoamérica se concentra en su totalidad en las capitales y, en ocasiones, en alguna otra ciudad.
} 
habitantes del mundo y con mayor crecimiento poblacional entre los años 2000 y 2020 incluyen cuatro ciudades latinoamericanas (Río de Janeiro, Buenos Aires, São Paulo y Ciudad de México), solo dos estadounidenses (Los Ángeles y Nueva York) y ninguna europea (Megalópolis... s/p). Si bien es cierto que la calidad de vida y el acceso general a ciertos servicios básicos puede ser cuestionable en estas megalópolis latinoamericanas, ${ }^{3}$ con estas cifras sería difícil argumentar que la mayoría de la población en Latinoamérica es rural y no urbana. ${ }^{4}$ No obstante, la concepción que Europa y Estados Unidos tienen de Latinoamérica no ha cambiado demasiado desde el siglo XIX: sigue siendo bastante folclórica, relativamente rural, a veces selvática y con frecuencia exótica. ${ }^{5}$ De allí la preocupación común de Manuel Atanasio Fuentes, Alberto Fuguet y Sergio Gómez.

En contraposición, los latinoamericanos, como demuestran las citas de los autores ya mencionados, en líneas generales nos hemos considerado siempre urbanos. Desde la Independencia, esta discrepancia entre cómo nos vemos y cómo nos miran los países a los que aspiramos emular ha sido motivo de angustia y motor de escritura para los escritores del continente. La obsesión de Latinoamérica con la ciudad (y lo que ella representa) es de larga data y responde a la relación que en el imaginario del continente guardan el espacio

\footnotetext{
${ }^{3}$ El geógrafo francés Jean Gottman acuñó el término megalópolis en su obra Megalopolis, The Urbanized Northeastern Seaboard of the United States para referirse a la aglomeración y unión de distintas áreas metropolitanas en una sola debido al crecimiento urbano acelerado. Uno de los principales problemas de las megalópolis es, entre otras cosas, el abastecimiento homogéneo de servicios como el agua o el transporte. Gottman analiza el caso estadounidense, pero estas condiciones y criterios pueden aplicarse a la mayoría de las capitales latinoamericanas en la actualidad.
}

${ }^{4}$ Creo conveniente aclarar que si bien la mayoría de la población latinoamericana se ubica en polos urbanos; la mayor parte del territorio (si lo contamos en kilómetros) sigue siendo bastante rural.

${ }^{5}$ Esta mirada es mucho anterior al siglo XIX y puede remontarse incluso hasta las Crónicas de Indias escritas durante la época del Descubrimiento, la Conquista y/o la Colonia. Creo que la referencia a estos textos es clara en el extracto citado de Manuel Atanasio Fuentes. Pese a esto, utilizo el siglo XIX como referencia primero, porque es el marco temporal de mi investigación y segundo, porque es el siglo en el que se concreta la independencia y a partir del cual se puede empezar a hablar con propiedad de repúblicas latinoamericanas. 
urbano con conceptos como civilización y modernidad. Esto resulta particularmente evidente en el siglo XIX ya que como bien señala Christopher Conway: "Nineteenthcentury Spanish American cultural and political history was defined by the desire to become modern, we could argue that cities embodied modernization better than any other idea or place" (23).

El espacio urbano ha desempeñado un papel destacado en la literatura y la cultura latinoamericana debido a la importancia histórica y política que tuvieron desde su fundación las ciudades, en especial las capitales, y al papel que estas desempeñaron dentro del proceso de modernización de las jóvenes repúblicas una vez conseguida la independencia. El protagonismo de la ciudad en la literatura decimonónica es indiscutible: aparece constante y repetitivamente en los cuadros de costumbres, las tradiciones, las crónicas y las novelas. Álvaro Salvador Jofre asegura que el espacio urbano fue uno de los elementos más novedosos y decisivos que la modernidad aportó a la lógica interna de la literatura y el arte finisecular (25). A pesar de esto, las novelas urbanas de finales del siglo XIX y principios del XX no han recibido la atención que merecen. A menudo se han clasificado de manera errónea (la novela urbana latinoamericana se ha estudiado de forma casi exclusiva como un fenómeno de la segunda mitad del siglo XX) y/o se han ignorado a pesar de que podrían proporcionar información crucial sobre la modernización de las capitales latinoamericanas, el desarrollo de la identidad nacional en el continente y el nacimiento de la literatura urbana en América Latina.

A través de la imagen física de la ciudad, los políticos e intelectuales liberales del siglo XIX trataron de reestructurar la identidad nacional utilizando modelos europeos idealizados que con frecuencia chocaron con los aspectos tradicionales considerados por 
un sector de la sociedad como los verdaderos rasgos latinoamericanos. A esta complicada situación se le sumó, además, la compleja relación que las recién fundadas repúblicas mantuvieron con las culturas autóctonas de cada zona. La novela urbana de finales del siglo XIX y principios del XX cuestionó y/o rechazó la idea de modernidad y nación propuesta y trató, en algunos casos, de negociar nuevas posibilidades de identidad. En esta disertación analizo la representación literaria de la ciudad latinoamericana en seis novelas urbanas mexicanas, argentinas y venezolanas (dos de cada país), publicadas entre 1880 y 1920, con la finalidad de identificar, a través de la imagen de ciudad presentada, las tensiones que el proceso modernizador produjo tanto en el espacio urbano y sus habitantes (y su modo de vida) como en el concepto de nación de cada república.

La selección de los textos estudiados en esta disertación - La gran aldea de Lucio Vicente López (1884), La rumba de Ángel de Campo (1890-1891), Todo un pueblo de Miguel Eduardo Pardo (1899), Ídolos rotos de Manuel Díaz Rodríguez (1901), Santa de Federico Gamboa (1903) y El conventillo de Luis Pascarella (1917) — responde a distintos criterios. Primero, si bien es cierto que en Latinoamérica el protagonismo literario de la ciudad a finales del siglo XIX fue indiscutible, no se escribieron novelas de ciudad con la misma intensidad en todos los países. Por ejemplo, en Colombia y Perú fueron más populares los cuadros de costumbres y/o las tradiciones que las novelas de ciudad. En Argentina, por contraste, sucedió lo contrario. Mi investigación se enfoca en México, Argentina y Venezuela por ser tres países que, entre 1880 y 1920, tuvieron una producción de novelas urbanas significativa. Por otro lado, la modernización fue un proceso generalizado en Latinoamérica a finales del siglo XIX y principios del XX; no obstante, no se vivió de la misma manera en todas las repúblicas. México, Argentina y Venezuela 
comparten el haber tenido durante este período a polémicas figuras autocráticas sentadas en la silla presidencial. Estos hombres estaban obsesionados con París, con la modernización del espacio urbano y con los avances tecnológicos del momento. Me refiero por supuesto a José de la Cruz Porfirio Díaz Mori (1830-1915) en México, Alejo Julio Argentino Roca (1843-1914) en Argentina y Antonio José Ramón de la Trinidad y María Guzmán Blanco (1829-1899) en Venezuela. ${ }^{6}$ La presencia de estos presidentes y la intensidad con que empujaron las reformas urbanas determinaron, en parte, tanto la producción de novelas de ciudad como la posición de los autores con respecto al espacio urbano y los cambios impuestos. Por último, las novelas en sí fueron seleccionadas a manera de díadas que facilitaran la comparación y el diálogo. Elegí, por cada país, una novela de ciudad que con el tiempo haya pasado a formar parte del canon de literatura nacional y/o del pensum escolar de lecturas obligatorias (La gran aldea, Santa e Ídolos rotos) y una novela urbana que haya sido ignorada y olvidada tanto en la construcción de literatura nacional como en los estudios literarios (El conventillo, La rumba y Todo un pueblo).

\footnotetext{
${ }^{6}$ A estos tres hombres no solo se les adjudicó la modernización de sus naciones sino también la pacificación de sus respectivos países luego de numerosas revoluciones y guerras civiles. Porfirio Díaz participó, entre otras batallas, en la guerra de la Segunda Intervención Francesa en México (1862-1867); Roca fue conocido como el artífice de la Conquista del Desierto (1878-1885) (campaña que anexó al territorio argentino extensiones de terreno antes ocupadas por distintas tribus indígenas) y Guzmán Blanco luchó en el bando liberal en la Guerra Federal (1859-1863) (conflicto bélico entre conservadores y liberales). Los tres ocuparon la presidencia en más de una ocasión; pero, además, dominaron la palestra política hasta entrado el siglo XX a pesar de no ser presidentes y/o ausentarse del país. Porfirio Díaz fue presidente durante un total de 31 años (el período más largo e ininterrumpido fue de 1884 a 1911). Roca completó dos períodos presidenciales de seis años cada uno (1880-1886 y 1898-1904); no obstante, dirigió el Partido Autonomista Nacional que se mantuvo en el poder durante 42 años (1874-1916). Guzmán Blanco ocupó la presidencia en tres ocasiones (1870-1877, 1879-1884 y 1886-1888); sin embargo, y al igual que Roca, dirigió la política venezolana hasta las postrimerías del siglo. Este período es conocido como el Liberalismo Amarillo (1870-1899), época en que todos los líderes políticos formaban parte o eran deudores de la hegemonía de Guzmán Blanco en el poder. En el caso de México y Venezuela, incluso se conoce con el nombre de estos presidentes al periodo histórico durante el cual se mantuvieron en el poder: el porfiriato y el guzmanato respectivamente.
} 


\section{Hipótesis y consideraciones a modo de preámbulo}

Esta investigación parte de la existencia de un significativo y poco estudiado corpus de novelas de ciudad publicadas en Latinoamérica a partir de la segunda mitad del siglo XIX. Estos textos dan cuenta de la relevancia que para las jóvenes repúblicas latinoamericanas tenía el entorno urbano (en cuanto espacio físico), el concepto que de este se tenía y la imagen de nación que este proyectaba. La novela urbana ha sido ampliamente estudiada como un fenómeno de los siglos XX y XXI; ${ }^{7}$ no obstante, en Latinoamérica hay novela urbana desde la segunda mitad del siglo XIX. Hay incluso críticos que encuentran el germen de la novela de ciudad en obras como El periquillo sarniento de José Joaquín Fernández de Lizardi publicado en 1816. Ana Arenas Saavedra, por su parte, afirma que para finales del siglo XIX "las ciudades latinoamericanas ya tenían sus novelistas: José Tomás de Cuellas (1180-1894) en México, Cirilo Villaverde (1812-1894) en Cuba, Alberto Blest Gana (1830-1920) en Chile, Machado de Assis (1857-1913) en Brasil y Miguel Eduardo Pardo (1868-1905) en Venezuela" (76-77).

Críticos, como Clara Mejía, han denominado "novela de ciudad" a la narrativa urbana del XIX para diferenciarla de la del siglo XX - catalogada como "novela urbana"alegando que, en la primera, la urbe aparece tan solo como escenario de los acontecimientos mientras que, en la segunda, la ciudad constituye el foco desde el cual se configura la narración (64). Esta división puede ser aplicable a ciertas novelas decimonónicas; pero resulta insuficiente para describir la producción de novelas urbanas finiseculares en general. Esta clasificación resulta además conflictiva ya que otros críticos, como Blanche

\footnotetext{
${ }^{7}$ A continuación, un par de ejemplos: City Fictions. Language, Body, and Spanish American Urban Space de Amanda Holmes y La novela urbana en Latinoamerica durante los años 1945 a 1959 de María Elena D’Alessandro Bello.
} 
Housman Gelfant, utilizan los términos de forma inversa. Housman Gelfant denomina "urban local fiction" a las narraciones en donde la ciudad funciona tan solo como fondo estático de las acciones de los personajes y "city novel" a aquellos textos en donde la ciudad participa de manera activa en la formación del personaje y en sus acciones (5). Si bien es cierto que la novela urbana del XIX no toca los mismos temas ni reproduce las mismas tensiones que la novela de ciudad del XX, esta diferencia se debe a que dichos textos hablan de ciudades distintas.

Si nos atenemos a la clasificación histórico-social que hace José Luis Romero de las ciudades latinoamericanas, las novelas del XIX hablan de la ciudad burguesa o moderna -a partir de 1880 aprox.- y las del XX hablan de la ciudad masificada -a partir de 1930 aprox.- (Latinoamérica: las ciudades y las ideas 293, 383). Salvando las diferencias culturales, económicas y sociales que separan a las ciudades del siglo XIX de las del siglo XX, la novela de ciudad de ambos periodos se hace posible precisamente gracias al entorno urbano. Estas novelas reproducen la ciudad, pero son a la vez producidas por la ciudad y no podrían entenderse fuera de su contexto. En conclusión, las diferencias entre la novela urbana del XIX y la del XX y XXI son temáticas y no de género ya que ambas reproducen el conflicto del individuo y/o sociedad por asimilar e integrarse a los cambios que se operan en su entorno. Por esta razón, en este estudio procederé a utilizar de forma indiferente los términos "novela de ciudad" y "novela urbana" para referirme a los textos que analizo; los cuales hacen uso de la ciudad como espacio activo que moldea la psicología y acciones de los personajes.

Tradicionalmente se ha considerado que las transformaciones de las capitales latinoamericanas ocurrieron en las últimas décadas del siglo XIX como consecuencia de la 
obsesión por el progreso. Si bien es cierto que las ciudades conservaron su aspecto físico colonial hasta casi las postrimerías del siglo; los cambios urbanos comenzaron con las alteraciones profundas sufridas por la estructura social de las sociedades latinoamericanas una vez consolidada la independencia. Las nacientes repúblicas perpetuaron casi en su totalidad, y a pesar del discurso igualitario independentista, la pirámide social colonial; sin embargo, la fisonomía de las clases altas cambió de forma radical. A los descendientes de las antiguas élites españolas se les sumaron militares, hacendados o caudillos que ascendieron social y económicamente a través de las guerras civiles y extranjeros enriquecidos con las nuevas políticas económicas. Las clases dirigentes urbanas finiseculares estuvieron compuestas por este grupo heterogéneo que utilizó las ciudades como simbólico campo de batalla de intereses y valores irreconciliables.

Se entiende entonces que el paso de Latinoamérica a la modernidad no fue ni tan fluido ni tan celebrado como se ha querido ver. La modernización se concretó y concentró en las urbes; no obstante, estas renovaciones arquitectónicas e inclusión de avances tecnológicos, publicitadas por los políticos de turno como manifestación del progreso nacional, escondieron alteraciones profundas al estilo de vida tradicional y modificaciones significativas en las relaciones interpersonales de los ciudadanos. La novela de ciudad ilustró muchos de los cambios urbanos físicos; pero más que esto, se ocupó de las tensiones que tales cambios instauraron en la sociedad. Y es que estas renovaciones destruyeron a nivel simbólico los sistemas tradicionales de representación creando conflictos en los grupos sociales identificados con las instituciones, íconos y/o espacios que la racionalización moderna y urbana deshizo a golpe de decreto (Ramos, 160). 
Por último, la modernización y la modernidad latinoamericana implicaron mucho más que reformas al perfil citadino, no solo debía ser moderna la ciudad, sino que también debían serlo sus habitantes. Por esta razón se institucionalizaron y popularizaron discursos orientados a la educación de los protagonistas de la modernidad. Los manuales de urbanidad y de conducta y los cuadros de costumbres constituyeron los principales discursos moldeadores y ordenadores del cuerpo social. La novela de ciudad finisecular estuvo en constante diálogo con ambos tipos de textos; en especial con el cuadro de costumbres, género que la antecede y del que toma muchos de las posturas con respecto a la ciudad, la modernización y la modernidad.

\section{Estado de la cuestión y objetivos de la investigación}

La ciudad latinoamericana ha sido fuente inagotable de información y ha generado numerosos textos de investigación que han buscado estudiar y explicar su complejidad. Me refiero a libros como Latinoamérica: las ciudades y las ideas (1976) de José Luis Romero, La ciudad letrada (1984) de Ángel Rama, La ciudad: hábitat de diversidad y complejidad (2000) compilado por Carlos Alberto Tovar, Fernando Viviescas y Edmundo Pérez y Ciudad, espacio público y cultura urbana (2010) compilado por Tulio Hernández. Estos textos abordan la ciudad desde puntos de vista históricos, sociales, políticos, culturales, etc; no obstante, la ciudad literaria ha sido dejada de lado o ha sido utilizada tan solo como fuente de apoyo secundaria de las ideas que en ellos se exponen.

Por otro lado, estudios como Lima en la tradición literaria del Perú: de la leyenda urbana a la disolución del mito (2003) de Eva María Valero o La ciudad en el imaginario venezolano: Del tiempo de Maricastaña a la masificación de los techos rojos (2002) de Arturo Almandoz sí rescatan la producción de la narrativa urbana de fin de siglo, 
pero sin dedicarse de manera exclusiva a ella ya que se pretende reconstruir la historia literaria de ciudades en específico (Lima y Caracas en los casos mencionados). Existen también análisis puntuales (como novelas de ciudad) de algunos de los textos a estudiar en esta disertación; ${ }^{8} \sin$ embargo, no se han realizado trabajos comparativos que establezcan conexiones literarias transnacionales entre la representación de la urbe en las diferentes novelas de ciudad de finales del siglo XIX y principios del XX y las tensiones y preocupaciones que estas generan y exponen. Tampoco se ha estudiado la relación entre el cuadro de costumbres, género literario urbano por antonomasia y precursor de la novela en Latinoamérica, y las novelas de ciudad finiseculares. Esta investigación pretende ayudar a llenar estos vacíos ya que, como señala Arturo Almandoz, es necesario analizar cómo se representó la ciudad y qué percepción comunicó esta imagen del proceso modernizador para poder entender los desbarajustes característicos de la modernidad en los países latinoamericanos (5).

Tomando todo lo expuesto en cuenta, los objetivos de esta disertación son: (1) analizar la representación literaria de la cuidad en la novela urbana latinoamericana de finales del siglo XIX y principios del XX. El interés de mi análisis recae no solo en la dimensión física de la ciudad (la cual suele estar incluida de manera detallada en los textos a estudiar ya que la literatura de la época seguía una estética realista) sino también en la dimensión política, social, económica, cultural, etc. de la urbe. ${ }^{9}$ Asimismo, me interesa (2)

\footnotetext{
${ }^{8}$ Algunos ejemplos: "Ciudad e inmigración: El conventillo de Luis Pascarella, novela de la transformación de Buenos Aires" de Joan Torres-Pou y "La gran aldea (1884) de Lucio Vicente López: la ciudad de Buenos Aires como tropo literario" de Frank Otero Luque.

${ }^{9}$ Aunque se mencionen con frecuencia, este estudio no pretende hacer un inventario de los cambios arquitectónicos de la modernidad urbana latinoamericana que se registran en las novelas de ciudad finiseculares. Tal investigación competería más bien al área de la historia del urbanismo o de la urbanización. Richard Dennis señala al respecto: "for a more fruitful dialogue between geography and literature focus less
} 
abordar el estudio de la representación de la ciudad como reflexión acerca de la vida moderna en la urbe que produce extrañamiento tanto en el protagonista como en el autor y en el lector. De igual manera, busco (3) mostrar cómo elementos o aspectos de la modernización, encarnados en la imagen literaria de la ciudad, fueron cuestionados y/o rechazados por la intelectualidad latinoamericana finisecular a través de la literatura. Para lograr esto es importante (4) estudiar la civilización, el orden y el progreso, rasgos primordiales de la modernidad, como conceptos entendidos por las clases dirigentes en términos europeizantes y casi siempre urbanos que validaban su hegemonía. Los elementos considerados conflictivos (desde el punto de vista racial, social, cultural, lingüístico, económico, etc.) fueron señalados, aislados y castigados, cuestión que se refuerza o se critica en la narrativa urbana. Por último, me enfoco en (5) abordar el proceso de modernización en Latinoamérica como un fenómeno urbano que implicó no solo renovaciones arquitectónicas a las ciudades sino también cambios económicos, políticos, sociales y culturales profundos que crearon tensiones y conflictos en las nacientes repúblicas. En este sentido, la narrativa urbana finisecular no solo arroja datos acerca de la modernización de las ciudades, sino que también revela aspectos acerca de la reformulación de los países latinoamericanos como nación ya que esta se conceptualizaba necesariamente desde las ciudades como centro del poder político y cultural de las repúblicas.

on the topographical detail and more on the topography of the text itself -its structure, composition, narrative modes, varieties of languages and style" (88). Con este estudio apunto entonces a analizar bajo qué luz y con qué finalidad se presentan estos cambios. También me interesa abordar la función que cumple la ciudad en los diferentes textos, distinguir o concatenar las percepciones que tienen los escritores a estudiar del espacio urbano y evaluar la asimilación (si se da) de lo moderno y lo urbano dentro del concepto de nación de los países latinoamericanos. 


\section{Fuentes teóricas y metodología}

Desde el punto de vista metodológico, la investigación propuesta no se apoya en un marco teórico individual, sino que apela a un diálogo con varios textos teóricos; en particular con los estudios culturales realizados por Ángel Rama en La ciudad letrada (1984), por Julio Ramos en Desencuentros de la modernidad en América Latina (1989) y por Cristopher Conway en Nineteenth-Century Spanish America: A Cultural History (2015). Rama plantea que en un sistema político/cultural donde la palabra era sinónimo de poder, las ciudades latinoamericanas, desde el periodo colonial hasta inicios del siglo XX, fueron producto de los intelectuales - primero peninsulares y luego criollos-que utilizaron la escritura para moldear e imponer un concepto utópico de ciudad basado en ideales, primero españoles y después franceses, que beneficiaban a la clase hegemónica a la cual ellos mismo pertenecían. Ramos, por su parte, establece que la crisis del sistema cultural tradicional que acarreó el proceso modernizador llevó a los escritores a precisar nuevos límites de autoridad. No es que la ciudad letrada haya dejado de existir a finales del XIX, sino que ya no servía o no se prestaba para legitimar la ideología y posición de la clase dirigente. En este sentido, la novela urbana de entre siglos es producto e imagen de este resquebrajamiento.

Abarcar un tema como el aludido trasciende los marcos de la producción literaria por lo que resulta necesario indagar también en textos de carácter histórico, sociológico y ensayístico. Entre ellos resultan de especial interés Civilización y barbarie o Vida de Juan Facundo Quiroga (1845) de Domingo Faustino Sarmiento y Ariel (1900) de José Enrique Rodó. Ambos ensayos definen, aunque de diferente manera, la dicotomía civilización vs. barbarie. A pesar de que Sarmiento y Rodó tienen una preocupación común los 55 años 
que separan la publicación de sus textos dan cuenta de los cambios de valoración en los conceptos ya nombrados, cambios que necesariamente impactaron y complejizaron la valoración del espacio urbano y la imagen que de este se tenía. Asimismo, hago uso de los discursos científicos decimonónicos europeos que fueron utilizados por las clases dirigentes urbanas latinoamericanas para justificar y legitimar su hegemonía. Me refiero al darwinismo, la eugenesia, la frenología, la criminología positivista, el determinismo social y/o biológico, entre otros. Las novelas a estudiar usan, revierten, cuestionan y/o ponen en evidencia dichos discursos. También resultan relevantes los discursos moldeadores del cuerpo social moderno entre los que se encuentran los manuales de urbanidad, el Manual de urbanidad y buenas maneras: de consulta indispensable para niños, jóvenes y adultos (1853) del venezolano Antonio Carreño es el más conocido, y cuadros de costumbres como Contratiempos de un viajero, Un llanero en la capital y El mercado de los venezolanos Juan Manuel Cagigal, Daniel Mendoza y Nicanor Bolet Peraza; Las tres tazas y El lenguaje de las casas del colombiano José María Vergara y Vergara y los contenidos en las colecciones tituladas Museo de limeñadas (1853), del peruano Ramón Rojas y Cañas, y Lima, apuntes históricos, descriptivos, estadísticos y de costumbres (1867), del también peruano Manuel Atanasio Fuentes.

Ante la escasez de trabajos acerca de la teoría y terminología de las novelas de ciudad en Latinoamérica, hago uso de textos que analizan otras tradiciones, como The American City Novel (1954) de Blanche Housman Gelfant. En este texto, la autora estadounidense establece, dependiendo de su estructura, tres categorías de novela urbana: portrait study, synoptic study y ecological study. Esta nomenclatura me permite justificar la selección de los textos a estudiar como novelas urbanas en donde la ciudad moldea a los 
personajes y a la trama y no como narraciones en donde la urbe aparece tan solo como trasfondo estático, categoría en donde tradicionalmente se ha colocado a las novelas seleccionadas. De igual importancia son textos como Images of the American City (1961) de Anselm Strauss, The Image of the City in Modern Literature (1981) de Burton Pike y The City in Literature (1998) de Richard Lehan ya que abordan la urbe literaria no solo como representación de la ciudad física (cuestión que se aprecia en las novelas realistas) sino también como una reflexión acerca de la vida y la experiencia de la urbe moderna.

\section{División del trabajo y resumen de contenidos}

Este trabajo está dividido en cuatro capítulos. En el capítulo I, "La ciudad como espacio evaluado y evaluador en el cuadro de costumbres latinoamericano", analizo la imagen de ciudad que se presenta en una selección representativa de cuadros de costumbres latinoamericanos. Críticos como Pedro Díaz Seijas (427) y Christopher Conway (61) consideran al cuadro de costumbres como el precursor de la novela en el continente. Fue además en este género donde se le dio protagonismo literario a la ciudad por primera vez. Considero entonces que, para comprender la novela de ciudad en Latinoamérica, así como los temas que aborda y las preocupaciones que expone, es necesario trazar sus inicios en el cuadro de costumbres.

Los cuadros de costumbres están ligados al tránsito de Latinoamérica a la modernidad; en ellos se negocia de manera constante el significado de lo nacional, lo civilizado, lo bárbaro, lo tradicional y lo moderno. Los escritores costumbristas tuvieron diferentes aproximaciones a los conceptos anteriormente nombrados; sin embargo, la mayoría compartió un elemento fundamental al cual los estudios costumbristas no han dado la importancia debida: el protagonismo literario de la ciudad. En este capítulo estudio, a 
través de la imagen de ciudad presentada en una selección de cuadros de costumbres escritos por Juan Manuel Cagigal, Ramón Rojas y Cañas, Daniel Mendoza, Manuel Atanasio Fuentes, José María Vergara y Vergara y Nicanor Bolet Peraza, la ambivalencia en la valoración del espacio urbano como portaestandarte de la modernización, su evolución y los cambios que conceptos como civilización y progreso sufrieron a lo largo del siglo XIX.

En el capítulo II, "Entre la ansiedad y el cuestionamiento: cambios urbanos, nueva fauna citadina y crisis de valores en La gran aldea de Lucio Vicente López y Todo un pueblo de Miguel Eduardo Pardo", examino el extrañamiento del ciudadano y del artista ante la ciudad moderna presente en La gran aldea (1882) del argentino Lucio Vicente López y Todo un pueblo (1899) del venezolano Miguel Eduardo Pardo. La historiografía tradicional latinoamericana ha popularizado la idea del paso ansiado y fluido de las jóvenes repúblicas a la modernidad. Sin embargo, la imagen de ciudad que se presenta en novelas como La gran aldea y Todo un pueblo no solo desmiente esta aproximación, sino que también expone aspectos contradictorios presentes en el proceso de modernización de Buenos Aires y Caracas respectivamente. En este capítulo analizo cómo el extrañamiento ante la urbe moderna, expuesto en los textos mencionados, lleva a un cuestionamiento tanto de la posición de Latinoamérica dentro de la modernidad occidental como de la efectividad y viabilidad del proyecto modernizador y las consecuencias que este trajo consigo.

En el capítulo III, "La urbe, los ciudadanos y las novelas de (de)formación: el caso de Ídolos rotos de Manuel Díaz Rodríguez y Santa de Federico Gamboa” analizo el papel negativo que juega la ciudad en un Bildungsroman, Santa (1903) del mexicano Federico Gamboa, y en un Künstlerroman, Ídolos rotos (1901) del venezolano Manuel Díaz 
Rodríguez. En las novelas de formación tradicionales, la ciudad juega un papel relevante como espacio que permite el aprendizaje del protagonista en su paso de la niñez a la adultez. De cierta manera, estas novelas hablan de la formación de los ciudadanos ya que estos individuos eventualmente pasan a formar parte de la sociedad. Por el contrario, en los textos de Gamboa y de Díaz Rodríguez es la ciudad, con todo su esplendor moderno, el espacio que no solo impide el desarrollo de los personajes, sino que además desencadena su deformación y, por extensión, su incapacidad de convertirse en ciudadanos útiles para las naciones modernas que se estaban tratando de instaurar en Latinoamérica desde mediados del siglo XIX. Los protagonistas de ambos textos, una prostituta y un artista, desempeñan además profesiones populares y cotidianas pero conflictivas dentro de la modernidad latinoamericana. En este capítulo estudio cómo esta particular aproximación a las novelas de formación encierra un cuestionamiento de la ciudad como espacio formador y civilizador y, a la vez, un señalamiento a las capacidades de las élites urbanas para construir y dirigir una nación moderna.

En el capítulo IV, "Delincuencia y criminales: la ciudad subalterna y la otredad urbana en La rumba de Ángel de Campo y El conventillo de Luis Pascarella" me enfoco en la imagen de los espacios urbanos marginales (ignorados por los estudios sobre la modernidad latinoamericana) que aparecen retratados en La rumba (1890-1891) del mexicano Ángel Campo y en El conventillo (1917) del argentino Luis Pascarella. La novela de ciudad finisecular, apegada casi siempre a los patrones del realismo europeo, se solía concentrar en la clase media y/o burguesa, sus costumbres y los espacios urbanos que frecuentaban; de manera que la heterogeneidad del tejido social urbano de la época quedaba suprimida en su totalidad. Estas novelas representan una sociedad moderna caótica, 
viciosa, de moral enferma pero siempre medianamente blanca, adinerada y homogénea. Textos como La rumba y El conventillo rompen con esta línea de representación y no solo visibilizan el supuesto lado bárbaro de la ciudad, sino que además lo abordan desde un punto de vista novedoso que desafía el andamiaje ideológico sobre el que se construyó la modernidad latinoamericana. En este capítulo estudio cómo estos textos apuntalan o cuestionan las dinámicas modernas que recluyen en ciertos espacios citadinos a individuos considerados peligrosos ya que sus comportamientos, costumbres, lengua o rasgos raciales los colocan fuera de la norma hegemónica.

\section{Breves consideraciones acerca del contexto social y literario}

A pesar de que el furor edilicio de la modernidad se intensificó en las últimas dos décadas del siglo XIX, época en la que comienzan a publicar sus textos los novelistas que analizo en este estudio, los cambios urbanos comenzaron a gestarse en el ámbito social y cultural desde décadas antes. Si bien es cierto que las capitales latinoamericanas conservaron su fisonomía colonial hasta casi el ocaso del siglo XIX, la estructura social y las relaciones interpersonales de los ciudadanos sufrieron, en líneas generales, alteraciones profundas una vez consolidada la independencia. En palabras de Germán Mejía Pavony: "genera dudas admitir, con base únicamente en la persistencia de la estructura física y la ausencia de monumentalidad edilicia, que en 1820 la ciudad se detuvo en el tiempo y sólo comenzó un acelerado proceso de transformación urbana nueve o diez décadas más tarde" (102).

Desde el punto de vista cultural, las guerras de independencia desataron los lazos que organizaban bajo rígidas leyes y modelos de conducta a las sociedades latinoamericanas. Junto con la emancipación llegó el afán por definir las identidades 
nacionales de las nacientes repúblicas, esfuerzos que respondieron, en un principio, a la necesidad de determinar las peculiaridades latinoamericanas en oposición a las del colonizador y así concretar el reconocimiento y la autonomía cultural. No obstante, estos esfuerzos no estuvieron exentos de incongruencias ya que lo considerado autóctono residía en el campo, espacio calificado como bárbaro y contrario a los nuevos ideales republicanos de civilización y progreso, encarnados solo en las urbes. Las ciudades, en contraposición, eran lugares cosmopolitas y durante la colonia habían constituido espacios predominantemente españoles y por tanto extranjeros.

Pese al discurso inclusivo de la gesta independentista, que propugnaba los derechos humanos para todos los ciudadanos por igual y proponía la creación de las nuevas repúblicas como espacios donde tendrían cabida todos los grupos sociales y sus costumbres, las jóvenes naciones se esforzaron por conservar la pirámide social colonial alterando solo la punta: los españoles fueron suplantados por los criollos en los cargos políticos y administrativos. Sin embargo, la fisonomía de esta nueva clase dirigente sí sufrió cambios sustanciales durante los primeros años de vida republicana. A los criollos hidalgos hijos de los conquistadores y/o fundadores de las ciudades, se sumaron caudillos que ascendieron social y económicamente a través de las guerras de independencia y luego a través de las civiles. Estos nuevos individuos ejercían el poder a través de un mando militar, con frecuencia autoimpuesto, y provenían casi siempre del campo, del espacio bárbaro nacional, cuestión que no agradaba a los criollos que abogaban por la civilización y que veían la entrada de la barbarie a las ciudades con su llegada. ${ }^{10}$ Por su parte los

\footnotetext{
${ }^{10}$ La valoración de los diferentes individuos considerados como padres de la patria no fue uniforme en las sociedades latinoamericanas ya que no todos los líderes de la independencia fueron de origen aristocrático. Simón Bolívar, por ejemplo, figura máxima de la emancipación latinoamericana, nació en Caracas en el seno
} 
caudillos se consideraban a sí mismos (y eran considerados por parte de la población) como

los nuevos padres de la patria, superiores de cierta manera a los descendientes de las antiguas élites ya que gracias a ellos se había consolidado la independencia. Sin embargo, ambos grupos comprendieron la necesidad de aliarse con el fin de concretar, justificar y legitimar su presencia en el poder. A este grupo se sumó más adelante una incipiente clase burguesa compuesta por nacionales y extranjeros enriquecidos a través del comercio y las nuevas políticas económicas que trajo consigo el proceso modernizador. Como puede observarse, la segunda mitad del siglo XIX estuvo caracterizada por una movilidad social que fue casi imposible de concebir y conseguir durante la Colonia. Pese a esto, no puede hablarse de una verdadera apertura ya que la única cosa en común que tuvo este heterogéneo grupo de intereses y valores irreconciliables fue la voluntad de proteger la posición de su grupo social.

de una familia mantuana (este vocablo fue utilizado en Venezuela desde la colonia hasta el siglo XIX para referirse a los blancos criollos que pertenecían a las aristocracias locales). El padre de Bolívar, Juan Vicente Bolívar y Ponte, era descendiente de colonos peninsulares, originarios de Vizcaya, mientras que su madre, María de la Concepción Palacios, era descendiente de un nieto de Fernando III de Castilla y de uno los acompañantes de Diego de Losada, fundador de Caracas. Tanto el parentesco lejano con miembros de la Corona Española como el nexo con los colonos y fundadores del territorio venezolano colocaban a Bolívar en la cúspide de la escala social (solo podía ser sobrepasado por un noble o funcionario peninsular). Por el contrario, la segunda figura más importante de la gesta independentista venezolana, José Antonio Páez, conocido como el Taita o el Centauro de los Llanos, era de origen canario, pero pobre y nacido en Portuguesa, estado que forma parte de los llanos occidentales del país. Páez entraba dentro de la categoría social y racial conocida en Venezuela como blanco de orilla. Los blancos de orillas eran aquellos individuos de origen canario, llegados a América luego de la conquista; eran blancos (en líneas generales), mas no eran ni peninsulares ni parte de las élites mantuanas. Los blancos de orilla ocupaban un escalafón social superior a los pardos, mestizos, indios y negros, no se dudaba de su condición de blancos; no obstante, no formaban parte de la élite pues no poseían riquezas y debían realizar actividades consideradas serviles como el pequeño comercio, la agricultura y la ganadería. Antes de unirse a la causa independentista, Páez desempeñaba oficios de llanero, comerciaba ganado y era experto con el lazo y la lanza. Se dice que antes de que Bolívar lo uniera a sus filas batallaba descalzo (el pie desnudo era considerado símbolo de la barbarie). Una vez conseguida la independencia, Bolívar perdió popularidad entre las élites mantuanas al abogar por el proyecto de la Gran Colombia. La aristocracia venezolana no vio con buenos ojos, entre otras cosas, que la capital del nuevo territorio fuera Santafé de Bogotá y no Caracas. Páez abrazó la causa de la separación de la Gran Colombia ganando la simpatía de un sector de la población. Pese a esto, durante sus períodos presidenciales siguió siendo rechazado por la aristocracia caraqueña que no podía dejar de ver en él al llanero bárbaro recién llegado a la capital. 
Por otro lado, las guerras civiles que azotaron a casi todos los países latinoamericanos desde mediados del siglo XIX fueron producto, en líneas generales, del enfrentamiento entre las dos posiciones ideológicas más relevantes del siglo XIX: conservadores vs. liberales. El pensamiento liberal abogaba por las costumbres y las corrientes políticas y económicas procedentes de Gran Bretaña y Francia y por una ruptura tajante con España y todo lo que implicara el pasado colonial (tradiciones, instituciones, legado político, etc.). El pensamiento conservador, por el contrario, apostaba por mantener y exaltar las tradiciones coloniales; consideradas como elementos fundacionales de la nación. Las tradiciones coloniales eran, evidentemente, de origen europeo (españolas); pero a fuerza de haberlas practicado por tanto tiempo, ya no se reconocían como extranjeras a pesar de serlo. El conservadurismo también protegió con particular ahínco la religión católica y el uso correcto de la lengua española. Por supuesto que los liberales hicieron uso del mismo idioma que los conservadores $y$, al igual que ellos, tuvieron poca o ninguna contemplación por las lenguas y tradiciones autóctonas de los indígenas como propias del suelo latinoamericano. No obstante, no impulsaron proyectos, que sí apoyaron los conservadores, como la creación de las academias americanas de la lengua ya que estas suponían el reconocimiento de un nexo cultural e institucional con la antigua metrópolis. ${ }^{11}$ En este contexto, creo pertinente señalar que la elección de una posición ideológica u otra respondía en muchos casos no solo a la postura política del individuo sino también a su

\footnotetext{
${ }^{11}$ La instalación de las academias americanas de la lengua respondía también a un ejercicio de poder a través del control del lenguaje. Dicho control garantizaba además un orden idiomático y, como bien se sabe, el orden fue un elemento fundamental del progreso y la modernidad. Fabián Andrés Llano asevera que, en el caso bogotano, el uso del más selecto castellano revela el efecto estructurador de "unas posiciones legitimadas para hablar bien y otras que son excluidas por no hacerlo (...) esto permite la imposición de un orden social armónico, mediante la emisión de gramáticas, urbanidades, y demás libros, que encierran en su conjunto la idea de reorganizar las formas de existencia en la ciudad" (22).
} 
posición social. Y es que, en la mayoría de los casos, la aristocracia criolla urbana se identificó con el pensamiento conservador y la burguesía citadina con el liberal.

Todos los cambios ya nombrados sucedieron casi únicamente en las ciudades. Desde la colonización, las urbes fueron el centro del poder político, económico y cultural. Controlar la ciudad equivalía a controlar al país. En 1845, Domingo Faustino Sarmiento definió por escrito la famosa dicotomía civilización (ciudad) vs barbarie (campo) que ha marcado al continente americano incluso hasta bien entrado el siglo XX; no obstante, esta idea existía ya en el imaginario latinoamericano desde la Conquista. El período de colonización fue de cierta manera una lucha entre las ciudades recién fundadas y el inmenso y desconocido territorio americano. En palabras de Alejandro Portes y John Walton: "the city did not arise to serve, but to subdue" (3). Las ciudades en Latinoamérica se desarrollaron a la inversa de las ciudades europeas. En Europa el desarrollo agrícola llevó de forma gradual a la organización de un polo urbano mientras que en América se asentaron las ciudades con la finalidad de que estas dominaran el campo (Rama 15). A nivel simbólico, las ciudades fueron el espacio de los españoles (civilización) y el campo el de los indígenas (barbarie). El texto de Sarmiento y su preocupación por el desarrollo civilizado de la nueva nación resalta la pugna entre los grupos de poder de Buenos Aires y los de las provincias argentinas.

Si bien el discurso de poder era emitido desde el mismo espacio urbano que en la Colonia, una vez concretada la independencia, la heterogénea clase dirigente republicana tuvo que buscar nuevas ideologías para apuntalar su posición. La modernización y sus distintos discursos (como la ciencia y la historia) cumplieron la función de legitimar, en términos europeizantes, los nuevos modelos de nación propuestos por las clases dirigentes. 
Como señala Herminio Nuñez: "quien establece las reglas del juego también determina la verdad de los conceptos, la dirección y el valor de las conductas, mezclando principios lógicos con contenidos de orden moral que se validan mutuamente" (193). Desde este punto de vista, en el siglo XIX existía en Latinoamérica solo una forma civilizada de habitar el único espacio no bárbaro del país; el resto del territorio y de la población constituían un concepto lejano, no solo geográficamente sino sobre todo social y culturalmente, que apenas se reconocía como propio. Los manuales de urbanidad y de conducta y los cuadros de costumbres constituyeron, desde el punto de vista oficial y literario, los principales discursos moldeadores del cuerpo social moderno; los cuales autentificaron como ciudadanos de la nación solo a los habitantes de la ciudad. Beatriz Gonzalez Stephan señala al respecto: "No existieron manuales de cómo ser buen campesino, buen llanero, buen gaucho o buen indio" ("Modernización y disciplinamiento..." 442).

El progreso en Latinoamérica se hizo visible y palpable, desde el punto de vista físico, en la modernización arquitectónica de las capitales. Se derrumbaron murallas, se construyeron avenidas icónicas -como el Paseo de la Reforma en Ciudad de México (abierto al público en 1867) o la Avenida de Mayo en Buenos Aires (inaugurada en 1894) -, se edificaron nuevos espacios públicos -como el Parque El Calvario en Caracas (abierto en 1883) -, y se instauraron los primeros ferrocarriles (Lima-Callao en 1851, Caracas-La Guaira en 1883, Bogotá-Facatativá en 1889). No obstante, y como ya he ilustrado, los cambios a la fisonomía urbana venían gestándose en el ámbito social desde décadas atrás. Lewis Mumford afirma que "the form of the city was the form of its social order" (172). Visto de este modo, las modificaciones arquitectónicas urbanas no fueron tan solo una copia de las urbes europeas; sino que, sin dejar de serlo, constituyeron una exigencia de las 
sociedades cuyas nuevas costumbres y valores exigían nuevas maneras de interactuar en el espacio público y en el privado.

Tanto las reformas arquitectónicas como estos cambios sociales produjeron un efecto de extrañamiento en el ciudadano que empezó a no reconocer su propio entorno urbano. Anselm Strauss define este fenómeno como disjunction, y lo califica como un estado cualitativo discontinuo entre un periodo de la ciudad y otro (21). Los periódicos del momento publicaron con frecuencia fotos panorámicas de los nuevos espacios junto a descripciones literarias (cuadros de costumbres) o no (crónicas) de los mismos. Estas imágenes pretendían poner la manifestación del progreso en las manos del lector para que este reconociese la nueva y mejorada ciudad moderna; sin embargo, ofrecían una versión reducida y simplificada de la misma. Anselm Strauss señala al respecto:

Such a picture really serves to reduce the image of the city to a suggestive expression (...) Furthermore, it simplifies the city by blurring great masses of detail and fixing the observer's attention on selected landmarks that emerged out of the relatively undifferentiated background (...) They achieve the simplification and impose the limitations which come from looking at a façade. They blot out what lies behind, or invite the viewer to disregard it, in favor of the interpretation presented by the façade itself. (69)

Teóricos como Burton Pike (ix) y el mismo Strauss (8) reconocen la imposibilidad de abarcar la totalidad de la ciudad (tanto física como culturalmente) debido a sus dimensiones y complejidad. No obstante, esas imágenes y escritos presentados en la prensa decimonónica no respondían, en su mayoría, a la irrepresentabilidad del espacio citadino 
sino a una retórica visual y textual que intentaba mostrar solo una cara de la modernidad. Será la novela de ciudad de finales del siglo XIX y principios del XX la que se ocupará de develar las tensiones que acarreó el proceso modernizador y, a su vez, cuestionar los discursos e imágenes que este fomentó. 


\section{CAPÍTULO I}

La ciudad como espacio evaluado y evaluador en el cuadro de costumbres

\section{latinoamericano}

Tanto en Europa como en Latinoamérica, la ciudad jugó un papel fundamental en el desarrollo de la novela. Richard Lehan afirma al respecto: "I also see the rise of the city as inseparable from various kinds of literary movement -in particular the development of the novel and subsequent narrative modes (...)"(6). El auge de la ciudad está además relacionado con la aparición de la burguesía; clase que también influyó en el desarrollo de la novela. Gracias a la clase burguesa, que buscaba leerse a sí misma y a su entorno, comienza la mercantilización de la literatura; primero con las novelas de folletín y, luego, con las novelas publicadas en formato de libro. Podría afirmarse que la ciudad consiguió en la novela el espacio perfecto para ser narrada. Si bien esto no deja de ser cierto, el primer género que le dio dimensión literaria a la ciudad en Latinoamérica no fue la novela sino el cuadro de costumbres, ${ }^{12}$ género narrativo que además ha sido señalado por críticos como Pedro Díaz Seijas (427) y Christopher Conway (61) como el precursor de la novela en el continente. ${ }^{13}$ Por esta razón considero que para comprender los inicios de la novela urbana

\footnotetext{
${ }^{12}$ La ciudad fue protagonista de algunos textos de la era colonial como La grandeza mexicana de Bernardo Balbuena, escrito en 1604 o Lima por dentro y por fuera de Esteban Terralla y Landa publicado en 1797. En la primera, Balbuena describe de forma minuciosa las bondades de la capital mexicana mientras que, en la segunda, Terralla y Landa se dedica a señalar con tono sarcástico y jocoso las costumbres limeñas. Mi estudio no incluye este tipo de obras pues en ellas se describe las ciudades coloniales y no las modernas (Balbuena, por ejemplo, dedica el capítulo VII a alabar el gobierno ilustre del virrey del momento). Por otro lado, ambas obras están escritas por españoles y no por latinoamericanos (es decir la mirada viene de afuera) y fueron publicadas cuando México y Perú eran aun virreinatos de España; por lo tanto, no se puede hablar con propiedad de construcción nacional a través de la imagen de la ciudad.

${ }^{13}$ Esta posición tiene sus detractores, Jorge Cornejo Polar, por ejemplo, asegura que "el costumbrismo derivó las capacidades descriptivas de los escritores que, de otro modo, pudieron haberse plasmado en la novela" (19).
} 
hispanoamericana a cabalidad, así como los temas que aborda y las preocupaciones que expone, es preciso trazar sus inicios en el cuadro de costumbres.

Los cuadros de costumbres alcanzaron máxima difusión en Latinoamérica justo después de la Independencia con el nacimiento de las nuevas repúblicas y su prensa; debido a esto, se convirtieron en uno de los principales vehículos de difusión de las identidades nacionales que, poco a poco, empezaron a delimitarse al fragmentarse el Imperio español. A pesar de la relevancia del género en su época, el costumbrismo ha sido largamente ignorado por la crítica literaria que lo ha considerado un género menor y de escazas cualidades estéticas. Jesús Semprum, por citar un caso, considera a la narrativa costumbrista tan deficiente que, a su modo de ver, apenas chapoteaba en el barro (325). No obstante, a través del estudio de los cuadros de costumbres se pueden dilucidar aspectos importantes no solo de la formulación como nación de las jóvenes repúblicas latinoamericanas, sino también del proceso de modernización por el que atravesaron a partir de la segunda mitad del siglo XIX.

El género costumbrista está ligado al tránsito de Latinoamérica a la modernidad. Así lo consideran Susan Kirkpatrick, quien afirma que los cuadros de costumbres constituyeron la manifestación ideológica del paso a las modernas sociedades burguesas (31), y Javier Lasarte, quien los cataloga como uno de los discursos constitutivos de las sociedades modernas latinoamericanas (175). En la escritura de los cuadros de costumbres se negocia el significado de lo nacional, lo civilizado, lo bárbaro, lo tradicional y lo moderno. Los escritores costumbristas tuvieron diferentes aproximaciones estos conceptos; sin embargo, la mayoría compartió un elemento fundamental al cual los estudios costumbristas no han dado la importancia debida: el protagonismo literario de la ciudad. 
Hablar de modernidad en Latinoamérica implica entonces un diálogo con el espacio predilecto donde se concretó y concretó la modernización de las jóvenes repúblicas.

Desde 1845, y gracias a la publicación de Civilización y barbarie o Vida de Juan Facundo Quiroga de Domingo Faustino Sarmiento, la antinomia civilización/ciudad y barbarie/campo quedó definida para el continente. La nación se pensaba y conceptualizaba desde la urbe, entendida primero como bastión de la civilización y, luego, como centro de la modernización, en medio de territorios mayoritariamente rurales y por extensión bárbaros. Sin embargo, esta dicotomía comenzó a perder su carácter maniqueo en las postrimerías del siglo XIX. Por ejemplo, en 1900, medio siglo después de la publicación de Facundo, el uruguayo José Enrique Rodó redefinió en Ariel los términos de civilización y barbarie y los límites geográficos que tales conceptos suponían al argumentar, entre otras cosas, que la barbarie, encarnada en el utilitarismo, inundaba las urbes. A pesar de que Sarmiento y Rodó tienen una preocupación común los 55 años que separan la publicación de sus respectivos textos dan cuenta de los cambios que sufrieron los conceptos de civilización y barbarie; cambios que a su vez impactaron y complejizaron la valoración del espacio urbano y la imagen que de este se tenía. Además, a la antinomia civilización vs. barbarie se le sumó la obsesión por lo moderno (entendido en términos franceses y/o ingleses) y la compleja relación de las nuevas repúblicas tanto con el pasado colonial como con las culturas autóctonas de cada zona.

Como ya expuse, el protagonismo literario de la ciudad en la segunda mitad del siglo XIX resulta evidente en distintos géneros: cuadro de costumbres, novela, crónica, tradiciones, entre otros. No obstante, fue en el cuadro de costumbres donde por primera vez se les dio dimensión literaria a las ciudades luego de conseguida la independencia de 
España. Y es que la mayoría de los escritores costumbristas escribían sobre la ciudad, desde la ciudad y para la ciudad. Críticos como Maida Watson (54), Javier Lasarte (177) y Pere Sunyer Martín (s/p) han resaltado el carácter urbano del costumbrismo hispano y su predilección por la ciudad, sus habitantes y sus costumbres; sin embargo, hasta el momento, no se han realizado estudios comparativos acerca de la representación y valoración de la ciudad en la tradición costumbrista de distintos países. ${ }^{14}$ Este capítulo pretende empezar a llenar este vacío a través del análisis de la imagen de la ciudad presentada en algunos cuadros de costumbres (publicados entre las décadas de $1830 \mathrm{y}$ 1870) de los siguientes escritores venezolanos, peruanos y colombianos: Juan Manuel Cagigal, Ramón Rojas y Cañas, Daniel Mendoza, Manuel Atanasio Fuentes, José María Vergara y Vergara y Nicanor Bolet Peraza.

La elección tanto de los costumbristas como de los cuadros a analizar responde, en parte, al acceso disponible a las fuentes primarias. Solo una minoría de los cuadros de costumbres publicados a lo largo del siglo XIX se encuentra hoy en día recogida en antologías; la gran mayoría aún no ha sido extraída de periódicos decimonónicos poco o nada estudiados. Por otro lado, los autores seleccionados muestran en sus escritos un interés particular por sus respectivas ciudades; las cuales aparecen de manera repetitiva en sus textos. Asimismo, debo aclarar que abordar todas las caracterizaciones del espacio urbano (y su relación con la civilización, la barbarie, la modernidad y la tradición) presentes en los

\footnotetext{
${ }^{14}$ El estudio más actual y completo del costumbrismo hispano se titula Revisitar el costumbrismo: cosmopolitismo, pedagogías y modernización en Iberoamérica. Este libro fue editado por Kari Soriano Salkjelsvik y Felipe Martínez-Pinzón y publicado por Peter Lang Edition en el 2016. La colección aborda diversos temas; no obstante, la representación de la ciudad en el cuadro de costumbres no es uno de ellos.
} 
cuadros de costumbres latinoamericanos sobrepasa las posibilidades y la longitud de este capítulo. Este análisis constituye tan solo un acercamiento inicial a algunos temas urbanos en el vasto universo de los cuadros de costumbres latinoamericanos. Este es un tópico que, a mi modo de ver, puede, y vale la pena, que se siga ampliando y estudiando. ${ }^{15}$ Las ciudades representadas en la pequeña muestra de textos costumbristas seleccionados serán abordada desde tres perspectivas: la ciudad como vacío de la civilización, la ciudad como parámetro de la civilización y la ciudad como espacio conflictivo entre la tradición y la modernidad. Nuevamente, esta división tripartita no pretende ser exhaustiva y responde tanto a las preocupaciones de los intelectuales del momento como a las inquietudes que los escritores a estudiar plasmaron en sus textos.

\section{El vacío de la civilización}

Los primeros cuadros de costumbres que aparecieron en los distintos periódicos latinoamericanos se publicaron alrededor de la década de 1840 y coincidieron con la consolidación de la vida republicana de los recién liberados países latinoamericanos. Estos escritos iniciales corresponden a una etapa de búsqueda y afianzamiento del estilo costumbrista (Barrios 13) y coinciden con los intentos de organización de los nuevos

\footnotetext{
15 Las capitales que abordan los cuadros de costumbres a estudiar, Lima, Bogotá y Caracas, tienen características históricas y culturales similares y, a la vez, disímiles. Por ejemplo, Lima y Caracas comparten una relativa cercanía geográfica a los puertos - Callao y La Guaira respectivamente-, por donde se recibían tanto las ideas como las mercancías europeas (francesas e inglesas en su mayoría) portaestandartes de la civilización, la modernidad y el progreso. Bogotá, por el contrario, se encuentra bastante retirada de los puertos marítimos. Además, está situada en las montañas, cuestión que, antes de la llegada del ferrocarril, dificultaba el acceso a la misma. Esta situación geográfica aislaba a Bogotá tanto de Europa como del resto de Colombia y Latinoamérica. Ahora bien, Lima y Bogotá comparten haber sido capitales de virreinato mientras que Caracas fue, hasta la independencia del país, una ciudad menor (el Virreinato del Perú fue, por supuesto, mucho más antiguo y grande que el Virreinato de Nueva Granada). Estas similitudes y diferencias influyeron, hasta cierto punto, la posición que asumieron respecto a la tradición y la modernidad los intelectuales decimonónicos y los costumbristas que escribieron sobre estas ciudades.
} 
gobiernos republicanos. Los primeros costumbristas latinoamericanos han sido acusados con frecuencia de imitar en demasía a los maestros españoles, Mariano José de Larra y Ramón de Mesonero Romanos (Picón Salas, "Prólogo" 6).${ }^{16}$ A pesar de que esta afirmación no deja de ser cierta, es precisamente en este primer período que aparecen ciertos temas, espacios y personajes que serán retomados por autores posteriores. La ciudad es uno de ellos.

El venezolano Juan Manuel Cagigal es uno de los primeros escritores que retrata Caracas en el cuadro titulado Contratiempos de un viajero, publicado en el periódico Correo de Caracas en 1839. En el texto, un narrador relata los infortunios sufridos en su viaje a la capital. En este cuadro se contrapone la pasada gloria de la ciudad durante los años independentistas, frente a un presente de abulia y desorden total:

En punto de disturbios y revueltas, ¿qué ciudad hay, antigua ni moderna, que pueda comparársele? Aquí se oyó en 1810 el primer grito de libertad que resonó en todos los ángulos de las nuevas repúblicas; aquí en 1811 la ilustre Municipalidad confirió al General Simón Bolívar el hermoso título de Libertador (...) aquí el pueblo, en 1835, despertando del letargo en que yacía, (...) dijo: yo soy el soberano, mi voluntad es la ley (...) aquí ese mismo pueblo, cual si estuviera fatigado del esfuerzo que acababa de hacer, contempla impávido y sereno la destrucción de su obra...(14-15)

\footnotetext{
${ }^{16}$ Es posible que el protagonismo del ambiente urbano en los cuadros de costumbres latinoamericanos sea, en parte, herencia del costumbrismo español. En 1832 Ramón de Mesonero Romanos, uno de los costumbristas españoles más leídos en Latinoamérica, aseguraba en su obra Escenas matritense: "me propuse (...) presentar al público español cuadros que ofrezcan escenas de costumbres propias de nuestra nación, y más particularmente de Madrid, que como corte y centro de ella, es el foco en que se reflejan las lejanas provincias" (3).
} 
Con esta nota negativa se abre el texto; el cual está narrado en primera persona y estructurado como una especie de carta que el viajero escribe a un "querido amigo" (14) para justificar su falta de correspondencia. El relato del viaje como tal se inicia con la llegada al puerto de La Guaira; el cual carece de la infraestructura y el personal que el viajero espera de una ciudad civilizada. El narrador señala: “Piensas que al puerto maldije? Te engañas; que habría sido maldecir en vano, pues ni La Guaira es puerto, ni en luengos siglos lo será” (15-16). Aquí se introduce el tópico que estructura el texto: Caracas, por más capital que sea, no es una ciudad civilizada ya que ni siquiera el puerto, que funciona no solo como entrada a la capital sino también como entrada al país, puede ser calificado como tal. Cagigal no es el primero en poner por escrito las deficiencias de La Guaira; ya en 1799 Alexander Von Humboldt había señalado que La Guaira más que un puerto era una rada con el agua constantemente agitada (Vila 156). ${ }^{17}$

El atraso de Caracas es denunciado desde todos los ángulos posibles. Comienza con el puerto y sigue con el único camino que comunica a la capital y a La Guaira a través del cerro el Ávila; sendero árido y agrio en donde el viajero concluye que más valdría tener

\footnotetext{
17 Para la época de publicación de Contratiempos de un viajero, el puerto de La Guaira tenía una infraestructura bastante rudimentaria. Por ejemplo, los barcos aún no podían atracar en el muelle (que estaba hecho de madera y no de un material moderno como el hierro) por lo que era necesario trasladar a los pasajeros desde y hasta los barcos en pequeños bateles movidos a fuerza de remo. Esto no solo hacía el proceso de embarco y desembarco mucho más lento y complicado, sino que, y tal como cuenta el narrador del cuadro de Cagigal, muchas veces el temperamental mar de La Guaira volteaba los bateles o los estrellaba contra el muelle o los barcos. Por esta razón, los pasajeros y sus enseres difícilmente llegaban secos a la orilla; cuestión que por supuesto no sucedía en los grandes puertos de Europa. Humboldt, por su parte, califica a La Guaira no como un puerto sino como una rada. Una rada es una especie de ensenada, de entrada, relativamente angosta, donde los barcos pueden fondear al abrigo de los vientos del mar abierto. La diferencia entre una rada y un puerto es que la primera es un fenómeno natural mientras que los puertos son construcciones humanas (producto de la civilización). Muchas radas se convirtieron en puertos por su situación geográfica ventajosa (el puerto de La Guaira es un ejemplo de esto). La descripción de Humboldt de La Guaira señala que la "barbarie" de la naturaleza aún no había sido doblegada por la supuesta mano civilizatoria del hombre.
} 
una cabra que una mula (18). Al divisar la ciudad a lo lejos el narrador se permite una pequeña descripción bucólica del paisaje que la rodea, la cual se ve prontamente interrumpida por la observación de que los estragos del terremoto de 1812 aún se dejan ver en cualquier lugar al que se dirijan los ojos (22). Caracas recibe al viajero con ataques de agua y huevos un martes de carnaval. Los asaltos lo dejan tuerto de un ojo y con la cara magullada. Ante la indignación del hombre los transeúntes le recuerdan: "No se impaciente, amigo, que en carnaval todo es permitido..." (25). Esta representación de las costumbres populares caraqueñas del período de carnaval tiene además un tinte de crítica, pues representa, a ojos de Cagigal, el atraso y, por extensión, la barbarie que aún sobrevive en la ciudad (Bohórquez 49).

La visión de Cagigal de Caracas no es del todo incorrecta. José Luis Romero señala que las ciudades latinoamericanas experimentaron un fuerte retroceso luego de las guerras de independencia y de las guerras civiles que azotaron a la mayoría de los países en las primeras décadas de vida republicana. Acusaron una disminución demográfica significativa y un estancamiento en el crecimiento espacial. ("La ciudad latinoamericana..." 301). No obstante, la perspectiva de Cagigal debe también ser entendida como la frustración de una generación ante la falta de concreción del modelo modernizador al que se apuntaba al finalizar la independencia. En Contratiempos de un viajero Caracas se dibuja "sólo desde la carencia" (Lasarte 177); desde todo lo que le falta para superar la barbarie. Es importante señalar que Cagigal elige como narrador de este cuadro a un extranjero que es capaz de ver la ciudad desde afuera pues no pertenece a ella. Es probable que Cagigal se sintiera como un forastero en su propia tierra luego de haber 
vivido 14 años en Europa. ${ }^{18}$ De ahí que Mariano Picón Salas concluya que lo que este autor, y los primeros costumbristas pretendían representar, es "el choque del hombre culto con un medio que encuentra todavía primitivo y desorganizado" ("Prólogo" 6).

Otro escritor que se dedicó a señalar las deficiencias de la capital de su país fue el peruano Ramón Rojas y Cañas quien en 1853 publicó una compilación de cuadros de costumbres ambientados en Lima titulada Museo de limeñadas. Este libro recoge los cuadros que Rojas y Cañas ya había publicado con anterioridad en el periódico El Comercio entre 1849 y 1853. Al respecto, Emmanuel Velayos señala que el autor peruano "recurre al formato del libro para darle una mayor estabilidad y permanencia a su producción discursiva" (220).

La colección resulta contradictoria desde el título ya que la palabra "limeñada" supone costumbres típicas de Lima; no obstante, encierra un tono censurable. Por otro lado, el mismo vocablo, al aludir a los modos de actuar propios de la capital peruana, define rasgos de personalidad identitarios de la ciudad y sus habitantes. La palabra museo, aunque popular entre los costumbristas del momento que veían en la recopilación de sus escritos una especie de archivo de la identidad nacional, también resulta conflictiva pues implica conservación y no necesariamente eliminación, fin último que, según los prólogos de Rojas y Cañas, tienen los textos presentados. Velayos percibe en Museo de limeñadas una ambivalencia "entre el intento de rescatar e institucionalizar la singularidad de la cultura y una vena satírica que pretende denunciar el ridículo" (222). Rojas y Cañas aclara en Parte

\footnotetext{
${ }^{18}$ Juan Manuel Cagigal, hijo del brigadier español Gaspar de Cagigal y Pontón y Matilde Odoardo Bucet de Gran Pré, venezolana oriunda de Cumaná, nació en Barcelona (Venezuela) en 1803. Tras la muerte de su padre se traslada a España en 1814. Estudia en la Universidad de Alcalá de Henares y en 1823 se dirige a París para estudiar matemáticas y física. Regresó a Venezuela en 1928 donde desempeñó cargos públicos, políticos, científicos y docentes.
} 
seria, texto que más que un cuadro funciona como uno de los tantos prólogos que anteceden a las limeñadas, lo siguiente:

Clamar contra ciertos hábitos ridículos no es odiar a su país. Querer desterrar alguno que otro error, no es apostatar de su patria, ni escarnecer ni mofarla. Al contrario, ridiculizar las mil pequeñeces viciosas que tienen cabida en nuestra sociedad, es darle una muestra de simpatía. Todo esto es amor a Lima, porque indica que el escritor quisiera verla limpia y exenta de lunares (81).

Como se verá a continuación, ese amor a Lima de Rojas y Cañas consiste en un afán de higienizar costumbres persistentes en la capital y no propias de una ciudad civilizada; sin embargo, en algunos textos se asoman visos de conservación de elementos tradicionales considerados como propios de Lima.

La modernidad en Latinoamérica implicó mucho más que reformas al perfil citadino. Tal como señala Cristopher Conway, "the city was more than an architectural challenge, it was also a vessel for shaping the experience of its inhabitants" (19). No solo debía ser moderna la ciudad sino también sus habitantes, razón por la cual se institucionalizaron y popularizaron discursos orientados a la educación de los protagonistas de la modernidad. Los manuales de urbanidad y de conducta, así como los cuadros de costumbres constituyeron los principales discursos moldeadores del cuerpo social. ${ }^{19}$ Los

\footnotetext{
${ }^{19}$ La mayoría de los manuales de conducta llevaban en el título o subtítulo la palabra urbanidad, vocablo que el Diccionario de la Real Academia Española define como: "cortesanía, comedimiento, atención y buen modo"; no obstante, su origen etimológico lo liga de forma irremediable a la urbe. Desde el título, estos manuales autentificaron como ciudadanos de la nación solo a los habitantes de la ciudad. En conclusión: solo existía una manera civilizada de habitar el único espacio no bárbaro del país.
} 
manuales de buena conducta son un subtexto claro en la mayoría de los cuadros que aparecen en Museo de limeñadas; no obstante, en Saludos y despedidas se aprecia la influencia de estos de forma más evidente. El cuadro se inicia de la siguiente manera:

En todas las sociedades cultas del universo, no sólo es una costumbre, mas es un deber de urbanidad en todo hombre medianamente educado, tocar la falda de su sombrero al pasar por delante de una señora, ya sea en la calle o en sus balcones. También es cierto que, en todas aquellas ciudades civilizadas, las señoras devuelven el saludo con amabilidad, y como pareciendo mostrarse lisonjeadas, ya que no agradecidas por este acto de urbanidad. $\mathrm{Y}$ esta reciprocidad de cortesía sucede aun cuando no se hayan visto ni en misa. En Lima, esto es muy malo. No sólo a las señoras extrañas, pero ni aun a las conocidas se debe saludar, por miedo a un desaire. Ejemplos son razones y no simples palabras. $(109)^{20}$

A continuación, Rojas y Cañas procede a ejemplificar las limeñadas que constantemente comenten los habitantes de la capital peruana quienes a claras luces no cumplen con la retórica civilizada expuesta en los manuales acerca de los saludos y las despedidas. Manuel Antonio Carreño, por ejemplo, dedica en su manual dos largos capítulos titulados "Del modo de conducirnos en diferentes lugares fuera de nuestra casa" y "Del modo de conducirnos en sociedad" cuyos apartados cubren la manera correcta de abrir y cerrar cualquier tipo de intercambio social.

\footnotetext{
${ }^{20}$ Las cursivas son mías para resaltar las palabras relacionadas con la ciudad, la civilización y la urbanidad.
} 
Museo de limeñadas censura casi todos los modos de actuar limeños que presenta; pese a esto, el cuadro que cierra el libro, Una verdad como un templo, constituye una excepción dentro de la colección puesto que rescata una limeñada digna de ser conservada y que aparecerá de manera constante en los textos de escritores posteriores - Ricardo Palma, por ejemplo-, como una marca de peruanidad: el uso de la saya y el manto. Al respecto señala Rojas y Cañas: "La saya y manto es, una limeñada perfecta y la cual debería mirarse con cierto respeto como que es un traje completamente característico del país, como que es un hábito peculiar y único en el mundo, de tan airosa silueta" (145). En medio de los esfuerzos oficiales por alejarse del pasado colonial para redefinir lo auténtico latinoamericano, este texto rescata una tradición característica limeña que data del virreinato en un intento incipiente por conservar dentro del proceso modernizador un elemento ya asumido como propio.

De los ejemplos anteriores se desprende que Rojas y Cañas, al igual que Juan Manuel Cagigal, no considera a la capital de su país una ciudad civilizada, y por ende moderna, pues no cumple con las normas de cortesía básicas que están presentes en cualquier "sociedad culta del universo" (Rojas y Cañas 109), entiéndase en cualquier ciudad de Europa. En Los apodos, el costumbrista peruano toca el tema de manera más clara al interpelar de forma directa al lector con la siguiente pregunta: “¿Se me querrá negar que Lima es todavía un gran pueblo con el genio de una provincia...de un pueblecito de por el interior?" (112). Sin embargo, este atraso reprochable es, a ojos de Rojas y Cañas, mejorable. Saludos y despedidas es un cuadro que se enmarca en una obra que, como expuse anteriormente, pretende mejorar las relaciones de los habitantes de la urbe a través del señalamiento y la crítica. De allí que el cuadro de Rojas y Cañas no tenga el tono 
desesperanzador presente en Contratiempos de un viajero de Juan Manuel Cagigal. No obstante, ambos escritores moldean su visión de la ciudad en negativo (Lasarte 177); construyendo así la idea de un vacío de civilización en las urbes que habitan.

\section{2."El emporio de las letras": la ciudad como paradigma de la civilización}

Daniel Mendoza inaugura la segunda época del costumbrismo venezolano con su cuadro Un llanero en el capital publicado en $1849 .{ }^{21}$ En él, un llanero del estado Guárico llamado Palmarote llega a la ciudad para resolver un problema legal y la recorre acompañado por el narrador, al cual conocemos como el Doctor. En este texto encontramos de manera explícita uno de los temas más recurrentes en la literatura latinoamericana: la pugna del campo y la ciudad. En el cuadro, se cotejan rasgos opuestos siguiendo el modelo de Sarmiento; es decir, se favorece siempre el elemento citadino civilizado: el habla coloquial del llanero vs. la rigurosidad gramatical del citadino, la vestimenta rústica de Palmarote vs. el cuidadoso atuendo del Doctor, el saber popular del primero vs la sabiduría académica del segundo. Julio Barroeta Lara acierta al calificar el cuadro de Mendoza como un contrapunteo entre la visión cerrera del llanero y la visión sensatamente razonada del Doctor (34). ${ }^{22}$

\footnotetext{
${ }^{21}$ En Formación y proceso de la literatura venezolana Mariano Picón Salas propone la siguiente división del costumbrismo venezolano: un primer período de 1830 a 1848, correspondiente a la oligarquía conservadora; un segundo período de 1848 a 1864, correspondiente a la oligarquía liberal y a la Guerra Federal; y, un último o tercer período de 1864 a 1885 correspondiente al septenio, quinquenio y bienio guzmancista (13). Si bien es cierto que esta división está delimitada por sucesos históricos más que por cambios fundamentales en la estética del género costumbrista; también es cierto que dichos acontecimientos influyeron en el desarrollo de Caracas como ciudad y en la percepción y valoración que de ella tuvieron los escritores costumbristas. Picón Salas adjudica además a Daniel Mendoza y a Un llanero en la capital la nacionalización del género costumbrista en Venezuela.

${ }^{22}$ El contrapunteo es la expresión musical por excelencia de los llanos venezolanos. En ella dos o más copleros "compiten" lanzando versos improvisados, referentes a algún tema establecido con anterioridad, hasta que uno de los dos se queda callado.
} 
En oposición a la imagen de Caracas dibujada por Juan Manuel Cagigal en Contratiempos de un viajero, Mendoza presenta a la capital como poseedora de la civilización y de los medios para llegar a ella. Durante el paseo citadino ambos personajes pasan por la Asamblea Legislativa, el convento de las Reverendas Madres Concepciones, el Seminario Tridentino y el Palacio de Gobierno; estructuras urbanas que se presentan como portaestandartes de la civilización. El recorrido se convierte entonces en una especie de iniciación del llanero, quien va con el pie desnudo (símbolo de la barbarie), en la civilización. Por su parte, el Doctor funciona como un traductor encargado de interpretar esa realidad que el llanero desconoce:

-Estamos, pues ya en la calle del Sol, Palmarote.

-¿En la caye del Sol, Dotor? ¿Acaso el sol sabanea más por esta caye que por las otras?

-Tienes razón: este es un nombre de capricho; pero eso viene de la necesidad de nombrar las calles, bien que algunas tengan un nombre alusivo o histórico. En los pueblos de las llanuras no se conoce esta necesidad, ni tampoco la de numerar las casas porque allí las poblaciones son reducidas...

Julio Barroeta Lara señala que Mendoza fue quizás el primero en traer a la literatura venezolana la antinomia campo-ciudad. Se le adelanta así a Manuel Vicente RomeroGarcía y su novela Peonía, publicada en 1890, y a Rómulo Gallegos y su famosa Doña Bárbara, publicada en 1929. A diferencia de estos escritores, en Mendoza es el campo el que se traslada primero a la ciudad y no a la inversa (39). La relación entre lo urbano y lo rural no es unidireccional en la obra de Mendoza pues luego de Un llanero en la capital, 
el escritor publica Palmarote en Apure, cuadro que presenta los mismos personajes, pero esta vez en los predios del llanero.

En Un llanero en la capital Caracas es vista como la representación del orden y del progreso. Mendoza le da el título de "El emporio de las letras" (98). A Palmarote no solo le sorprende la apariencia, organización e infraestructura de la ciudad sino también las costumbres de sus habitantes. Antes de salir ve al Doctor haciéndose la toilette, un hábito desconocido para él. Abruma entonces a su anfitrión con preguntas acerca de la escobilla de los dientes, la relojera, el espejo, los guantes, etc. Víctor Goldgel señala que durante el siglo XIX "la moda, sobre todo, prometía orden" como "expresión de una actitud normativa" (140). Seguir la moda equivalía a llevar una vida civilizada; por lo que la ignorancia de Palmarote en los asuntos de la toilette y el vestuario debe ser entendida como un rasgo más de la barbarie del personaje. No obstante, y al contrario de lo que otros escritores de la época plantean, Mendoza no ve la oposición campo y ciudad como una dicotomía irreductible.

Es cierto que a lo largo del texto se puede apreciar una actitud algo paternalista y condescendiente del Doctor para con Palmarote y una cierta burla del llanero hacia las conductas citadinas, ${ }^{23}$ no obstante, también encontramos en el cuadro una revaloración de elementos calificados tradicionalmente como propios de la barbarie. Uno de ellos es el registro del habla coloquial del llanero que según Bladimir Ruiz debe ser visto como "una

\footnotetext{
${ }^{23}$ Douglas Bohórquez encuentra en Palmarote un "discurso despectivo y sarcástico en relación a los distintos objetos modernos, de lujo, que a cada paso observa en la casa del Doctor. Se expresa así, lateralmente, a través de la calificación de cachibaches que otorga a los objetos modernos, de lujo, una crítica satírica a esa sociedad moderna, de consumo, que comienza a despuntar en las ciudades venezolanas y particularmente en Caracas" (51).
} 
estrategia letrada de incorporación (al menos al nivel simbólico) de "lo llanero" al espacio emblemático de identidad nacional" (76). Otro elemento reconocido es la existencia de un saber rural popular del que se carece en la ciudad y que resulta necesario para la construcción del país. A continuación, una cita ilustrativa:

-Hablemos claro. Dotor: ¡aquí (en el Seminario Tridentino) se conseña a papelero...Cuando saben hacer cuatro gasetas, se creen ya unos hombresitos; pero coja usted un Dotor y póngale una soga en la mano, pa que lo bea too regao en siya. Ni sabe apiarsele a un toro, ni arriar una madrina, ni trochar una potranca, ni pasar su siya, ni maldita cosa. ¡Y esto no es sencia!...

-iQue disparates, Palmarote! ¿Qué sería de la sociedad si todos fuéramos arreadores de madrinas, como dice usted? Los cultivadores de las ciencias, como los industriales, como los que ejercen oficios, etc. todos, todos prestan un gran servicio a la sociedad, auxiliándose recíprocamente, y es necesario que todos desempeñen funciones distintas...

-Pare, pare, Dotor, que ya beo que usted también es papelero (104-105).

De este extracto se deduce que la única razón de por qué el saber popular del llanero tiene valor es porque el Doctor, que funge como ojo civilizador, así lo considera. A los ojos de Javier Lasarte esta revaluación de los elementos "bárbaros" representa "la proposición de un pacto mestizador como símbolo de la nueva nacionalidad" (179). La revalorización (al menos retórica) del llanero en Venezuela continuó después de la publicación de los cuadros de Mendoza. 
En enero de 1892 salió a la venta el primer número de El cojo ilustrado, la revista

más relevante y longeva de la modernidad venezolana. Resulta significativo que en una

revista de distribución urbana se haya utilizado en la primera página precisamente una

ilustración del llanero domador. ${ }^{24}$ Con el tiempo, la figura del llanero se asentó en la cultura

nacional como símbolo de lo auténticamente venezolano. ${ }^{25}$ En Un llanero en la capital

Mendoza parece señalar que el llanero y sus costumbres no deben ser obviados ni

${ }^{24} \mathrm{El}$ título de esta revista hace referencia a la novedad de tener ilustraciones en las publicaciones periódicas; no obstante, El cojo ilustrado no fue la primera revista con imágenes que hubo en Venezuela. La pionera en el área se titulaba El Zulia ilustrado y se publicó de octubre de 1888 a diciembre de 1891. Fue creada y dirigida por el periodista zuliano Eduardo López Rivas y producida por la casa editorial Imprenta Americana localizada en la ciudad de Maracaibo, capital del estado Zulia, y propiedad del propio López Rivas. La Imprenta Americana fue además el primer taller tipográfico venezolano en imprimir fotografías, grabados y trabajos en tricromía. Fue una institución de vanguardia que alcanzó fama internacional por la implementación continua de técnicas modernas de impresión; de hecho, participó y obtuvo premios importantes en la Exposición Universal de París de 1889. En la portada del primer número de El Zulia ilustrado apareció un grabado del prócer independentista Rafael Urdaneta, conocido con el epíteto de "el más leal de todos los leales a Simón Bolívar". No sorprende la elección de un prócer como imagen para la portada de una revista cultural. Recordemos que durante la modernidad se intentó crear un pasado común republicano a través de la imagen de los padres de la patria que lucharon en la Independencia. Lo que sí resulta atípico es la elección de Urdaneta, un zuliano, por encima de otros nombres. Caracas ejercía su poder como centro cultural y administrativo de Venezuela a pesar de que Maracaibo, la segunda ciudad más relevante del país, la superaba en avances tecnológicos relacionados con el periodismo. El presidente del momento, Antonio Guzmán Blanco, solo tenía ojos para la capital y se empeñó durante toda su gestión de hacer de ella una París latinoamericana, dejando de lado la modernización (tanto arquitectónico como cultural) de otras ciudades venezolanas. Eduardo López Rivas buscó llenar este vacío con El Zulia ilustrado. En la portada del primer número el periodista zuliano afirma: "Revista mensual fundada con el objeto de dar a conocer en el resto del país y en el extranjero al Zulia, en todas sus producciones y bellezas naturales y en todas sus manifestaciones de progreso" (1). Esta voluntad de divulgar la civilización y los progresos del Zulia es la misma que caracteriza la obra del costumbrista peruano Manuel Atanasio Fuentes, por citar un ejemplo. No obstante, López Rivas debe dar a conocer Maracaibo, y por extensión el Zulia, al resto de Venezuela antes de poder hacerlo internacionalmente. De allí que escoja un prócer zuliano para adornar la portada. López Rivas también fue el responsable de dibujar y reproducir el primer plano topográfico de la ciudad de Maracaibo; el cual apareció en El Zulia ilustrado en 1889. López Rivas acompaña el mapa con la siguiente aclaratoria: "Hacía falta un plano topográfico de Maracaibo que, por la modicidad de su precio, pudiese salir en la maleta del viajero como un recuerdo de la ciudad, figurar en todas las oficinas y contribuir con su profusa circulación fuera del estado, al mejor conocimiento de la capital del Zulia". Los políticos del momento se esforzaron en concentrar la modernización en Caracas; pese a esto, y como se desprende de la explicación anterior, no faltaron detractores que intentaran empujar la civilización en sus respectivas ciudades.

${ }^{25}$ Esto supuso la exclusión tácita del acervo nacional de zonas como la costa, los Andes o la selva que poco o nada tienen que ver con la forma de hablar, la cultura y las tradiciones llaneras (oriundas de la zona central del país). 
eliminados, sino pasados por el tamiz de la civilización y la ciudad para ser asimilados. En este sentido Mendoza antecede a Rómulo Gallegos quien en Doña Bárbara propone una síntesis similar entre campo y ciudad como futuro exitoso para la nación. ${ }^{26}$

El peruano Manuel Atanasio Fuentes propone un "pacto mestizador" similar al de Daniel Mendoza en su obra Lima, apuntes históricos, descriptivos, estadísticos y de costumbres publicada en 1867. El título mismo del texto revela la hibridez temática de los escritos que en él se presentan. De manera estratégica, Fuentes resta importancia al elemento literario de sus textos y le agrega carácter científico al denominarlos apuntes. Fuentes retrata la misma ciudad y la misma realidad que otros costumbristas peruanos de la época; como el ya mencionado Ramón Rojas y Cañas o el popular Manuel Ascencio Segura. No obstante, la anécdota jocosa presente en la mayoría de los cuadros de estos dos escritores se convierte en cuidadosa descripción en los "apuntes" de Fuentes. Si bien es cierto que el costumbrismo se caracterizó más por su naturaleza descriptiva que por su afán narrativo (Watson 33), es importante entender que la descripción en Fuentes va más allá de una licencia literaria. Lima, apuntes históricos, descriptivos, estadísticos y de costumbres clasifica y ordena la ciudad, desde sus espacios hasta sus habitantes, oficios y costumbres, con la finalidad de mostrar que "la sociedad de Lima nada tiene que envidiar

\footnotetext{
${ }^{26}$ Doña Bárbara ha sido estudiada como un texto que presenta la irreductibilidad de la dicotomía civilizaciónbarbarie; sin embargo, a mi modo de ver, la novela plantea todo lo contrario. Es en la síntesis entre el campo y la ciudad donde está la clave del éxito. El personaje principal, Santos Luzardo, es un joven nacido en el llano, pero educado en la capital. Luzardo regresa al interior con todo el saber citadino para mejorarlo; no obstante, solo puede empezar sus proyectos una vez que ha probado que no ha olvidado los conocimientos rurales aprendidos en su infancia. En el capítulo VIII le llega la gran prueba al protagonista: la doma de un caballo salvaje. Luzardo triunfa pues la lleva a cabo personalmente, como cualquier otro llanero, y no a través de un tercero como un citadino recién llegado. Para ampliar la lectura acerca de las relaciones de dominio y resistencia entre los grupos de poder y los subalternos presentes en Doña Bárbara (como modelo de la literatura que integra los grupos populares al imaginario nacional) consultar el artículo de José Castro Urioste titulado "Utopía y transgresión: El imaginario nacional en la obra de Rómulo Gallegos".
} 
á la de la mas adelantada capital" (V). Una ciudad organizada equivalía a una ciudad moderna.

Manuel Atanasio Fuentes pasa revista de los diferentes ministerios y viceministerios del gobierno como elementos demostrativos de la modernidad en la administración pública. También da cuenta de novedades higiénicas, como la canalización subterránea del desagüe; de innovaciones arquitectónicas, como el nuevo edificio de la Penitenciaría (conocido como el Panóptico), y de la entrada al Perú de las grandes invenciones modernas como el ferrocarril, que pasó a comunicar Lima con las dos localidades de veraneo más famosas de la clase alta y media limeña (El Callao en 1853 y Chorrillos en 1858). Recordemos que en el siglo XIX el lujo y el ocio también constituyeron un rasgo de modernidad. Es precisamente en esta época cuando surge tanto el concepto moderno de ocio como la idea de que la ciudad es un espacio para ser disfrutado (Strauss 57). De allí que muchas de las renovaciones arquitectónicas urbanas se hayan enfocado en instaurar parques, bulevares, plazas y paseos.

Un elemento particular de la Lima que dibuja Fuentes es la inclusión de clases sociales y raciales (junto a sus oficios, trajes y habla particular) prácticamente ignoradas en los cuadros de costumbres de Rojas y Cañas o Segura; autores que retrataban una Lima en particular, una especie de subciudad dentro de la urbe: la ciudad de la clase media. Este enfoque en una clase social particular excluye a la gran ciudad (Pike 41); y es que la Lima de la clase media resultaba una realidad intangible no solo para el resto de la nación sino para la mayoría de los habitantes de la propia capital. En este sentido la obra de Fuentes constituye una suerte de vademécum para los limeños puesto que las distintas realidades 
económicas y sociales hacía que la clase media y alta ignoraran la Lima de las clases bajas y viceversa. ${ }^{27}$

Hay que reconocer, sin embargo, que la inclusión de los diversos tipos raciales y sociales limeños en Lima, apuntes históricos, descriptivos, estadísticos y de costumbres constituye, al igual que la presencia del llanero en Un llanero en la capital del venezolano Daniel Mendoza, un intento más retórico que real de inserción de la diversidad en el modelo moderno de nación. Los mulatos, negros, indios y mestizos de Fuentes son, a pesar de su ojo científico, una imagen idealizada de la realidad. La preocupación central de Fuentes no era retratar la diversidad sino presentar una imagen civilizada de Perú a Europa; de allí que Lima, apuntes históricos, descriptivos, estadísticos y de costumbres haya sido publicada en París. El propio Fuentes aclara en el prefacio:

Nuestro propósito ha sido dar, en globo, una idea de nuestra organización política; hacer ver que en establecimientos de instrucción y de beneficencia públicas, ramos que dan exacta idea de la civilización de un país, estamos tan adelantados como podemos estarlo (...) que las costumbres populares se han dulcificado y estinguídose, en su mayor parte, las introducidas por el mal gusto y la barbarie y, en fin, que no merecemos ser juzgados como rudos habitantes de las selvas, semi-cubiertos de plumas que reciben á

\footnotetext{
${ }^{27}$ Es difícil saber que tanto acceso tenían las clases bajas, en su mayoría analfabetas, a los cuadros de costumbres. Diana Galindo Cruz señala al respecto: "Existen algunas referencias a la lectura pública de los periódicos, lo que permite suponer el acceso a la información por parte de un público analfabeto; no obstante, y debido a la falta de cifras al respecto, resulta complejo hacer un aproximado del porcentaje de la población que seguía con regularidad las publicaciones, y mucho menos aún, resulta imposible estimar el valor o la incidencia de los textos en el juicio y las decisiones del público no especializado" (128).
} 
flechazos á los huespedes que llegan á su chozas para devorarlos después, crudos, en un banquete de familia (XIII-IX).

Emmanuel Velayos asevera que "el trabajo con tipos sociales partió de la necesidad de estabilizar la incertidumbre de la realidad social" (217); por tanto, se puede concluir que la obra de Fuentes constituye un intento de impartir orden en medio del caos. Cada clase racial y social aparece en los textos de Lima, apuntes históricos, descriptivos, estadísticos $y$ de costumbres ocupando un espacio específico y desempeñando oficios determinados para poder transmitir una idea de orden, y por extensión de progreso, de la que se carecía en la capital peruana muy a pesar de los avances en infraestructura. ${ }^{28}$

El éxito del costumbrismo en Latinoamérica se debió, en parte a la necesidad de autodefinición de las nacientes repúblicas que buscaban identificar y describir los aspectos que constituían la experiencia nacional (Watson 11). Lima, apuntes históricos, descriptivos, estadísticos y de costumbres, y otras obras de Fuentes como Guía del viagero en Lima publicada en 1860, constituyen una respuesta por parte del escritor peruano a los libros de viajes escritos por europeos sobre Latinoamérica a finales del siglo XVIII y principios del XIX. Estos textos presentaban, en general, una imagen exótica y selvática de las entonces colonias españolas y rara vez se enfocaban en los centros urbanos a menos que fuera para describir sus carencias, como se puede observar en el ya citado ejemplo de Alexander Von Humboldt al llegar al puerto de La Guaira en Venezuela. A diferencia de Juan Manuel Cagigal y Ramón Rojas y Cañas, tanto Daniel Mendoza como Manuel Atanasio Fuentes "ya no se concentran en lo que no se encuentra sino en lo que se tiene y

\footnotetext{
${ }^{28}$ Para leer acerca de la escritura de tipos sociales como método tanto ordenador como revisionista del pasado y el futuro de la nación ver "Las costumbres y los tipos como interpretaciones de la historia: Los mexicanos pintados por sí mismos y el Museo de cuadro de costumbres" de José David Cortés Guerrero.
} 
en las bases que esto puede proporcionar en los procesos de construcción nacional" (Ruiz $81)$.

\section{Ciudad, tradición y modernidad}

En 1866 se publicó en Colombia Museo de cuadros de costumbres y variedades, proyecto enciclopédico, dirigido principalmente por José María Vergara y Vergara, que reunió en seis tomos los cuadros de costumbres de los escritores colombianos del momento: José Manuel Groot, José Manuel Marroquín, Manuel Pombo, Ricardo Silva, entre otros. Esta compilación, al igual que los textos analizados anteriormente, es producto de la necesidad de autodefinición; no obstante, en este caso no solo se buscaba "la colombianidad" para diferenciarse de España sino también para trazar una línea limítrofe entre Colombia y los demás países pertenecientes a la antigua Gran Colombia. Esta preocupación llevó a los costumbristas colombianos a eliminar el título de Los colombianos pintados por sí mismos y rebautizar el proyecto, cuestión que Vergara y Vergara aclara en el prólogo:

Este libro puede ir a Europa (...) i como los señores europeos están tan atrasados en cuanto a nuestra historia i nuestra jeografía, que hasta ahora empiezan a hacerse cargo de que en estas Indias occidentales hai algo más que indios e indias (...) si llegasen a ver dicho título, nadie podría quitarles de la cabeza que la obra contenía descripcion de las costumbres de los venezolanos i de los ecuatorianos (II). ${ }^{29}$

29 Les Français peints par eux-mêmes, publicada entre 1840 y 1842, es una obra compuesta por ocho volúmenes que recoge y describe, a través de textos e imágenes, los tipos y costumbres francesas de mediados del siglo XIX. Esta recopilación sentó un precedente, fue bastante popular (incluso fuera de Francia) e influenció la creación de series similares en España y Latinoamérica. Entre 1843 y 1844 se publicaron dos entregas de Los españoles pintados por sí mismos, en 1852 apreció Los cubanos pintados por sí mismos y en 
Museo de cuadros y costumbres y variedades comparte con Lima, apuntes históricos, descriptivos, estadísticos y de costumbres del peruano Manuel Atanasio Fuentes no solo la época de publicación sino también el afán cientificista, clasificatorio y ordenador. Sin embargo, la imagen de nación que construyó el proyecto colombiano fue más abarcadora que la de Fuentes; no solo porque incluyó el punto de vista de más escritores sino porque, junto a los tipos y costumbres citadinas, ${ }^{30}$ fueron incluidos los habitantes, espacios y tradiciones rurales. A pesar de esta voluntad totalizante de la colección, su principal director, José María Vergara y Vergara, se dedicó particularmente a escribir sobre Bogotá.

En el primer volumen de Museo de cuadros de costumbres y variedades aparece $E l$ lenguaje de las casas de Vergara y Vergara. Este cuadro retrata tres tipos de casas bogotanas diferentes. Estas viviendas se asocian a tres épocas distintas - la Colonia, los primeros años postindependentistas y la era republicana- que se identifican a su vez con los tres nombres con los que se llegó a conocer a la capital colombiana: Santafé, Santafé de Bogotá y Bogotá respectivamente. Vergara y Vergara anula casi por completo la narración para favorecer la descripción minuciosa de los espacios. De hecho, en el texto no

1855 Los mexicanos pintados por sí mismos. Este tipo de colecciones encajaba muy bien con el afán clasificatorio y la búsqueda de autodefinición de las nuevas repúblicas latinoamericanas, de allí su popularidad (aunque para la época de publicación de estos textos Cuba aún no era un territorio independiente de España). Museo de cuadro de costumbres y variedades sigue el mismo patrón de las series anteriores; no obstante, no comparte el nombre debido a que, como el prólogo bien señala, la palabra colombianos podía resultar confusa pues antes de existir la República de Colombia existió la Gran Colombia.

${ }^{30}$ Dentro de la fauna citadina descrita en Museo de cuadros de costumbres y variedades, aparecen algunos tipos propios de las urbes y que dan cuenta del cambio incipiente de las sociedades latinoamericanas de rurales a urbanas. Por ejemplo, Ignacio Gutiérrez Vergara presenta a los distintos tipos de cachacos afirmando que la palabra es "fecunda en metamorfosis en la sociedad bogotana" (101). 
aparece ningún personaje, tan solo se hace referencia a los nombres de los dueños de las casas. Vergara y Vergara asegura que solo la fisonomía de los hogares bastará para conocer a sus habitantes:

El lector habrá extrañado el silencio profundo que hai en la casa que hemos recorrido. No se oye hablar a nadie, no hemos visto ninguna persona. ¿Tiene curiosidad de ver las personas que la habitan? Pues por la descripción de la casa puede asignarles fisonomía, edad, costumbres, vestidos, etc. I viva seguro de que no se equivocará ni en un cinco por ciento $(395) .{ }^{31}$

A mi modo de ver, en esta curiosa aproximación a los personajes a través de sus casas, hay ecos del discurso científico de la frenología, pseudociencia que promulgaba la capacidad de conocer el carácter y la personalidad de un individuo tan solo a través del estudio de su cráneo y sus facciones. En el caso del texto de Vergara y Vergara se puede conocer a las personas a partir del análisis de la fisonomía de sus viviendas. Al respecto, Gaston Bachelard afirma que las casas y habitaciones constituyen diagramas de psicología y que, por tanto, pueden leerse (70). En este sentido, en El lenguaje de las casas la descripción minuciosa no es solo una elección literaria/estética, sino que resulta necesaria como herramienta de lectura de la vivienda y como método científico para diagnosticar la psicología y preferencias, entre tradición y modernidad, de los habitantes de las casas.

\footnotetext{
${ }^{31}$ Otro costumbrista colombiano, Ricardo Silva, padre del conocido José Asunción Silva, y a quien Vergara y Vergara dedica Las tres tazas, escribe el cuadro Tres visitas. En este texto el narrador se da cita con los habitantes de las tres viviendas que aparecen en El lenguaje de las casas en sus respectivas quintas. Las visitas del narrador constituyen no solo una caminata por la urbe, sino una especie de paseo en el tiempo a través de las tres épocas señaladas en el texto de Vergara y Vergara. El narrador se traslada de casa en casa y de ciudad en ciudad al deambular en un mismo espacio por las tres versiones de la capital colombiana. Va de Santafé - capital del Virreinato de Nueva Granada-, a Santafé de Bogotá - capital de la nueva república de Colombia- y de allí a Bogotá - capital de Colombia y ciudad moderna. En Las tres tazas se aprecian los cambios urbanos de manera cronológica mientras que en El lenguaje de las casas y Tres visitas se superponen.
} 
Al final del cuadro, el autor afirma dejar en manos de los lectores la valoración positiva o negativa de las tres épocas de la capital enmascaradas en las tres casas (401); no obstante, esto no es más que una táctica retórica puesto que son las preferencias de Vergara y Vergara las que hilan las descripciones. La casona colonial, habitada por una familia patricia y sus descendientes, es descrita como amplia, con muebles robustos de madera de nogal y grandes jardines internos. Se señala además que la familia posee otras propiedades y que vive de esas rentas (característica típica de las familias patricias de antaño). Los rasgos principales de la segunda vivienda, habitada por una familia empobrecida durante el proceso de independencia, son la ruina, los muebles de baja calidad fabricados de madera de pino y el desorden de los jardines. La última quinta es la más moderna pero también la más pequeña. Las habitaciones se encuentran atiborradas de objetos y muebles en donde más que su utilidad se subraya su fragilidad: "una mesa redonda, que no es redonda porque es ovalada, i en vez de una gruesa i única pata como tenian las mesas redondas, tiene cuatro patas largas, encorvadas, frájiles (fragility) que se reúnen en una flor de lis para volver a apartarse a buscar el suelo en que se apoyan" (399). En la antinomia que forman la robustez de la casona colonial y la fragilidad de la casa moderna se esconde la valoración negativa de la modernidad por parte del costumbrista colombiano. La presencia de estas tres casas en una misma urbe, espacio que además lleva tres nombres diferentes -impuestos según el autor por las leyes y las costumbres (401) -, revela la superposición y conflicto entre hábitos tradicionales y modernos que se vivía día a día en las ciudades latinoamericanas del siglo XIX.

La división generacional tripartita es un tema repetitivo en la obra de Vergara y Vergara quien ya en 1863 había publicado Las tres tazas. Este cuadro también aborda la 
transición de Bogotá de ciudad colonial a urbe republicana y el cambio del estilo de vida, de virreinal a cosmopolita, de sus ciudadanos a través de la imagen de las bebidas servidas -chocolate, café y té respectivamente- en tres convites diferentes: uno ofrecido en 1813 , otro en 1848 y el último en $1865 .{ }^{32}$ De nuevo, las tres épocas y bebidas son asociadas a los tres nombres que tuvo la capital colombiana a lo largo del siglo XIX. Las tres tazas ensalza las costumbres sociales asociadas a la Colonia y critica las modas extranjerizantes que acarreó la modernidad. Así, las tertulias retratadas presentan la crisis de identidad nacional que trajo consigo el resquebrajamiento de la estructura social colonial al culminar la independencia y las pugnas de las dos grandes corrientes ideológicas del XIX: los conservadores vs. los liberales. Es conveniente recordar que estos conflictos ideológicos eran necesariamente urbanos puesto que las capitales, como centros del poder político y administrativo, imponían las pautas culturales al resto de la nación.

Es de notar entonces tanto el interés de Vergara y Vergara por Bogotá y sus cambios como la capacidad de abordarlos sin hablar de espacios públicos. Tanto en El lenguaje de las casas como en Las tres tazas, la narración se desarrolla en su totalidad en el interior de las quintas que aparecen en los respectivos textos. En el caso de Las tres tazas, es a través

\footnotetext{
${ }^{32}$ Esta asociación de bebidas con la sucesión de las épocas no es única de Vergara y Vergara, el costumbrista peruano Manuel Ascencio Segura también la usa en su texto El té y la mazamorra. En el caso de Segura la mazamorra se antepone al té como elemento autóctono en una familia en donde el padre prefiere la bebida inglesa y la madre la peruana. La preocupación de Segura radicaba no en la entrada de modas extranjeras sino en la apropiación incorrecta de estas que dejaban como resultado un adefesio. A continuación, una cita ilustrativa:
}

-Ven acá, ¿qué modo de servir el té es este? Aquí falta azúcar, y luego, estas dos cucharas no son de té sino de comer y aquella taza es más grande que las otras y de pinta diferente. -Señor, la señorita no me ha dado para comprar azúcar, la vecina de enfrente se llevó prestadas las dos cucharitas que faltan y no las ha traído hasta ahora y esa taza la he puesto en lugar de la otra, porque la señorita la tiene ocupada con un remedio. (605) 
de la descripción tanto del interior de los salones como de los eventos en sí -el vestuario, lo que se come y se bebe, de lo que se habla, la música que se escucha y baila- que se señalan los cambios que la fisonomía bogotana comenzaría a portar años después. Al respecto, Gaston Bachelard señala que es precisamente la imagen literaria de la casa la que posee el poder de integrar el pasado, presente y porvenir del hombre (36). ${ }^{33}$

Vergara y Vergara veía con recelo la abundancia de modas extranjeras pues estas suplantaban lo propio que, según él, se encontraba en las tradiciones heredadas del pasado colonial. En El lenguaje de las casas, el narrador describe con desdén la casa moderna pues, entre otras cosas, se celebra lo francés y lo inglés en detrimento de las tradiciones nacionales: "sobre las paredes empapeladas estaban no el San Cristóbal, santo patrono de las buenas casas santafereñas sino Garibaldi, Lamartine i la reina Victoria" (398). En Las tres tazas, la preferencia de Vergara y Vergara por las costumbres y etiqueta santafereñas

\footnotetext{
${ }^{33}$ La respuesta al porqué de la preferencia de Vergara y Vergara de hablar de cambios urbanos a través de la imagen de espacios privados se puede conseguir en las particularidades propias del proceso de modernización bogotano; el cual difirió, tanto desde el punto de vista físico como ideológico, del mismo fenómeno en otras capitales suramericanas. Ciudades como Buenos Aires, Lima o Caracas, por citar algunos ejemplos, tienen en común una relativa cercanía geográfica a los puertos por donde se recibían tanto las ideas como las mercancías europeas (francesas e inglesas en su mayoría) portaestandartes de la civilización y el progreso. Bogotá por el contrario no solo está situada en el medio del país, alejada de los puertos marítimos, sino que además está localizada en las montañas cuestión que, antes de la llegada del ferrocarril, hacía el acceso a la misma sumamente difícil. El propio narrador de Las tres tazas exclama escandalizado ante las nuevas costumbres que presencia: "Yo que he jurado no salir de Bogotá y morir aquí encerrado entre las retrógradas costumbres de mis cariñosos amigos, ¿cómo me encuentro de repente trasladado a un puerto de mar?" (130). Recordemos que las ciudades portuarias han sido desde la antigüedad urbes eclécticas por antonomasia donde se mezclan razas, lenguas, costumbres e ideas; el extrañamiento del ciudadano ante los cambios vertiginosos que sufren las urbes modernas lo hace sentir en un puerto a pesar de no estarlo. En el imaginario de las élites letradas decimonónicas tanto argentinas como peruanas y venezolanas la civilización, encarnada siempre en las urbes, se localizaba necesariamente cerca de las costas; mientras que en Colombia se situaba en el interior del país. De hecho, y tal como propone Felipe Martínez Pinzón en Una cultura de invernadero, las élites colombianas definieron el espacio nacional a partir de una escala vertical donde el clima y la altitud definían el nivel de civilización y, por extensión, de progreso y modernidad. A mayor altitud, menos calor, población más blanca (raza considerada como superior por la pseudociencia de la época), individuos más productivos y, por ende, más progreso y civilización. Con este punto de vista las élites urbanas colombianas justificaron la superioridad de Bogotá y las zonas altas sobre el resto del país.
} 
es evidente. La primera taza se lleva el epíteto de "edad de oro" (118) mientras que la última taza provoca el siguiente lamento: “¿qué demonios es esto? Repetía yo (...) llorando sobre mí y sobre mi patria: ¿qué demonios es esto?”(130). Y es que el cambio de etiqueta registrado en Las tres tazas alude a alteraciones sociales mucho más profundas de lo que se puede apreciar a primera vista ya que, como señala Ricardo Visbal Sierra, tanto el vestuario como la música y la culinaria son elementos que estructuran los valores nacionales (1). Con todo, resulta conveniente aclarar que cuando Vergara y Vergara se queja del amor de la clase alta por lo europeo se refiere solo a lo francés y lo inglés. Las tradiciones españolas coloniales, ensalzadas en la narración de la primera taza, evidentemente eran también de origen europeo; no obstante, y a fuerza de haberlas practicado por tanto tiempo, ya no se reconocían como extranjeras a pesar de serlo. Por tanto, para Vergara y Vergara no hay incongruencia al señalar que "con tales jícaras de chocolate (haciendo referencia a Nariño y compañía) fue que se llevó a cabo nuestra gloriosa emancipación política" (119).

El auge de las clases medias y burguesas, representadas en Las tres tazas en los personajes de Juan de la Viña, anfitrión de la segunda tertulia, y el marqués de Gacharná, organizador del tercer convite, significa el declive de la antigua aristocracia criolla, a la que el propio Vergara y Vergara pertenecía como descendiente de una familia patricia criolla que abrazó en su momento la causa de la emancipación, y el olvido de conceptos, como la hidalguía, a ella ligados. Tal como afirma Anselm Strauss: "Cities change, forcing those who live in them to face the inadequacies of what once were tried and true conceptions" (17). El desprecio que el narrador de Las tres tazas siente por las prácticas usureras de Gacharná, quien tiene un almacén en la calle Real, no solo es producto del 
sobreprecio con que vende los productos; sino también de la falta de hidalguía que el costumbrista colombiano ve en tales prácticas. Recordemos que la llegada de los españoles a América supuso la imposición de una sociedad estratificada donde la clase social que se ocupaba estaba determinada, no solo por el color de la piel, sino también por el trabajo que se realizaba; cuestión que además definía la pureza de sangre de los individuos. Ser cristiano viejo implicaba no tener antepasados ni judíos ni musulmanes y, además, no realizar ningún tipo de trabajo asociado a estas razas (comercio a los judíos y agricultura a los musulmanes). El concepto de hidalguía alude etimológicamente a ser "hijo de algo", cuestión que bien se aprecia en el salón de la marquesa de San Jorge, anfitriona del primer convite en Las tres tazas, donde se exponen los retratos de los fundadores del marquesado. El marqués de Gacharná, por el contrario, no es hijo de ningún nombre relevante y su marquesado es producto de un intercambio económico con el gobierno de Noruega, quien lo nombra cónsul del país y le da la naturalización noruega y el marquesado a cambio de que monsieur de Gacharná desempeñe su cargo sin remuneración salarial (134).

Como ya se ha mencionado, los cambios a la fisonomía urbana venían gestándose en el ámbito social décadas antes de que comenzara el furor edilicio de finales del siglo XIX y principios del XX. No es casual entonces que, en el caso de Las tres tazas, Vergara y Vergara escogiese los convites como ejemplificación de los cambios urbanos. Si bien es cierto que las tertulias eran prácticas de sociabilidad antiguas en Latinoamérica; en el caso de Bogotá suplieron las funciones que a partir de mediados del siglo XIX tomaron espacios como el club o el casino en otras capitales latinoamericanas. Como referencia, el conocido Club del Progreso se fundó en Buenos Aires en 1852. Tanto los clubes como los casinos constituyeron centros de sociabilidad nocturna, abiertos primero a los hombres y después 
a ambos sexos, impensables durante la Colonia; época en la que la sociabilidad que se contemplaba era siempre diurna y se reducía a transacciones de la vida diaria (ir al mercado, visitar a amistades y/o conocidos enfermos o escuchar misa) y a la celebración de fiestas religiosas o cívicas, matrimonios y entierros. La única iniciativa remotamente parecida al Club del Progreso en la Bogotá de mediados del siglo XIX la tomó el propio Vergara y Vergara junto a Eugenio Diaz al fundar la tertulia El Mosaico en 1858, de la cual nació un periódico que llevó el mismo nombre. ${ }^{34}$

Resulta sugestivo dentro de este concepto de nuevas formas de sociabilidad y agrupación republicanas y modernas la definición que ofrece el diccionario de la Real Academia Española de la época de la palabra "club” -“junta de individuos de alguna sociedad política clandestina"-35 y "tertulia" -“junta de personas de ambos sexos, para conversación, juego y otras diversiones honestas"- (citado en Gordillo Restrepo 26). La clandestinidad asociada a la palabra club implicaba también ocupaciones deshonestas, como los apuestas, cuestión que no podía ver con buenos ojos, y muchos menos tomar parte de, un conservador católico como Vergara y Vergara. A pesar de que los avances tecnológicos de la modernidad, primero el gas y luego la electricidad, transformaron la vida nocturna urbana de manera radical, la tertulia siguió siendo por mucho tiempo, y en Bogotá en particular, la única modalidad de vida nocturna no censurada y practicada por una buena parte de la sociedad republicana. No obstante, y tal como retrata Las tres tazas, los cambios

\footnotetext{
${ }^{34}$ Cabe acotar que la tertulia de El Mosaico fue concebida como un espacio cultural y literario mientras que el Club del Progreso fue fundado originalmente como una agrupación con fines políticos y económicos. Equiparo ambas instituciones en el contexto de este estudio ya que, a pesar de sus diferencias, ambos espacios posibilitaron el resurgir de la vida social de las élites de sus respectivos países en términos urbanos modernos.

${ }^{35}$ Esta definición de "club" aún la contempla el diccionario de la Real Academia actual.
} 
ya eran apreciables. La tertulia de 1813 comienza a las ocho de la noche y culmina a medianoche, la de 1848 comienza a la misma hora, pero termina a las cuatro de la mañana y la de 1865 se inicia a las diez de la noche y los invitados se retiran un poco antes de las cuatro de la madrugada.

El tránsito de Latinoamérica a la modernidad no fue entonces ni tan uniforme ni tan celebrado como algunos intelectuales de la época quisieron hacer ver. Bogotá, una ciudad situada en las montañas y alejada de los puertos, canal de entrada de la civilización francesa a Latinoamérica, mostró, al contrario de otras ciudades como Caracas o Buenos Aires, una resistencia mayor a los cambios de la tan aclamada modernidad. Al contrario de otros países, los costumbristas colombianos de mediados del siglo XIX no tuvieron una reacción demasiado adversa al pasado español. Textos como El lenguaje de las casas y Las tres tazas revelan "la complejidad de una sociedad que se debatía entre la continuidad con el pasado y los desafíos propios de la realidad republicana" (Velayos 208) y la incertidumbre de los habitantes de la capital colombiana quienes oscilaban entre considerarse bogotanos (modernos), santafereños (tradicionales) o algo en el medio. ${ }^{36}$

\footnotetext{
${ }^{36}$ La olvidada y/o ignorada Soledad Acosta de Samper plasmó en algunos de sus textos reflexiones similares a las de Vergara y Vergara con respecto a la capital colombiana. El cuadro Mi madrina lleva el significativo subtítulo de Recuerdos de Santafé. En él se construye la imagen de la madrina del narrador como representación de la ciudad de Santafé a través de las descripciones de su persona, su vivienda y sus costumbres. Por ejemplo, la madrina sí tiene un San Cristóbal en la puerta de su casa (415), aún toma chocolate todas las tardes (414) y espera el regreso de los españoles para que pongan fin a las muchas revoluciones que se daban unas tras otras desde la independencia de Colombia (412). El narrador, quien escribe desde la Bogotá moderna, concluye que el recuerdo de su madrina persiste "como la página más dichosa de su existencia" (422); lo cual equivale a señalar que fue Santafé el mejor capítulo de la historia de la capital colombiana. Pese a ser uno de los escritores más prolíficos de la segunda mitad del siglo XIX colombiano, los cuadros de Soledad Acosta de Samper no fueron incluidos en Museo de cuadros de costumbres y variedades, colección que reunió de forma casi exclusiva el punto de vista de escritores hombres. La única mujer que aparece en el primer tomo de Museo de cuadros de costumbres y variedades es María Josefa Acevedo de Gómez, considerada como la primera escritora colombiana de la era republicana. Si bien fue incluida, la presencia de Acevedo de Gómez en la colección de cuadro de costumbres tampoco es demasiado notoria. Solo aparece un texto de Acevedo de Gómez mientras que se incluyen seis de José María Vergara y Vergara.
} 
Otro costumbrista que se ocupó con atención de la capital de su país fue el venezolano Nicanor Bolet Peraza; quien mostró un interés particular por la ciudad de Caracas y su historia. Por esta razón, muchos de sus textos están agrupados bajo el título de Cuadros Caraqueños. Uno de los más conocidos es El mercado. El cuadro comienza con la descripción de la demolición de la antigua plaza de la Catedral y sus alrededores para construir la nueva plaza Bolívar (que aún hoy en día se conserva), uno de los proyectos

A pesar de sus muchos logros, estudios y de su posición social ventajosa (era hija del general Joaquín Acosta, prócer de la independencia, y esposa de José María Samper, uno de los periodistas más relevantes del momento), Soledad Acosta de Samper, al igual que tantas otras escritoras decimonónicas, nunca logró sacudirse del todo el estigma que suponía ser mujer y escribir en el siglo XIX. Por esta razón, en Novelas y cuadros de la vida Sur-americana (colección donde se incluye el texto Mi madrina), Acosta de Samper recurre a su esposo, José María Samper (quien sí fue incluido en Museo de cuadros de costumbres y variedades), como voz legitimadora que justifica su participación en una actividad reservada a los hombres. Samper escribe en el prólogo:

La esposa que Dios me ha dado (...) ha estado muy léjos de aspirar á los honores de otra publicidad mas durable que la del periodismo. La idea de hacer una edición en libro, de las novelas y los cuadros que mi esposa ha dado á la prensa (...) nació de mi exclusivamente; y hasta he tenido que luchar con la sincera modestia de tan querido autor para obtener su consentimiento. (...) hija única de uno de los hombres más útiles y eminentes que ha producido mi patria (...) mi esposa ha deseado ardientemente hacerse lo más digna posible del nombre que lleva (...) y ya que su sexo no le permitia prestar otro género de servicios a esa patria, buscó la literatura (...) He querido, por mi parte, que mi esposa contribuya con sus esfuerzos, siquiera sean humildes, á la obra común de la literatura que nuestra joven república está formando (...) Tan legítimos deseos justificarán, así lo espero, la presente publicación. (s/p)

Cristhopher Conway estima que "the faitth in the civilizing power of the word was a fundamental cornerstone of nineteenth-century Spanish America" (54); no obstante, ese poder civilizador debía ser ejercido solo por los hombres de las élites urbanas. La mujer decimonónica estaba limitada a los espacios privados y crear nación y civilizarla/modernizarla a través de la escritura era una tarea pública y, por extensión, masculina. No es de extrañar entonces que en el ya mencionado prólogo Samper resalte los atributos femeninos "deseables" (a ojos de la época) de su esposa, como la modestia y la humildad, y se atribuya la idea del libro a sí mismo para así excusar a su esposa. Samper pretende insertar los textos de Soledad en la incipiente literatura nacional, pero lo hace de manera sutil, alegando la filiación de la escritora con el general Joaquín Acosta y su incapacidad, como mujer, de luchar físicamente por la patria. Lo más probable es que un libro como Novelas y cuadros de la vida Sur-americana, publicado en Europa y apenas tres años después de Museo de cuadros de costumbres y variedades, fuese considerado un atrevimiento por parte de Soledad Acosta de Samper de no ser por el prólogo "atenuante" de José María de Samper. Un estudio exhaustivo de la ciudad en el cuadro de costumbres latinoamericanos también debe incluir voces subalternas como la de Soledad Acosta de Samper. 
de ornato urbano más ambicioso del entonces presidente encargado Antonio Guzmán Blanco. ${ }^{37}$ La voz narrativa ve con desdén las reformas (iniciadas en 1865) alegando:

La arcada no era muy elegante que digamos, más era antigua y monumental, y con ella desaparecería un mundo de recuerdos históricos. ¿Quién ha dicho que no hubiera podido aprovecharse la vieja estructura combinándola con las obras nuevas de embellecimiento que el progreso de nuestra culta capital estaba reclamando? Vamos, la cosa no tiene ya remedio. Lo bonito ha sustituido a lo histórico y solemne. (212)

La voz narrativa indica que lo que en realidad necesitaba renovarse era el mercado que la plaza albergaba al cual califica de "mercado de aldea"; espectáculo indigno para estar colocado frente a la casa de gobierno y la catedral (212). No obstante, el narrador rememora con tono nostálgico el mercado, su organización por sectores, las comidas que se vendían, los episodios de discusión de precios entre los dependientes y las criadas, la barbería y la frutería. Al final de las memorias concluye que las transformaciones propuestas no son tal cosa sino "una profanación en nombre del progreso" (240).

Bolet Peraza no veía en el pasado de la capital la degradación señalada por autores como Juan Manuel Cagigal ni en su presente el parámetro civilizador planteado por escritores como Daniel Mendoza. La preocupación de Bolet Peraza radicaba en que la bandera del progreso y civilización del guzmancismo estaba destruyendo íconos de la ciudad y por ende dejándola sin historia. Burton Pike señala que "The stubborn spatiality

\footnotetext{
${ }^{37}$ Aunque desconozco la fecha de la primera publicación de El mercado, se puede deducir que debió de haber sido entre 1865 , año en el que se inicia la demolición de las arcadas originales de la antigua plaza de la Catedral, y, quizás, 1874, año en el que culminan las renovaciones de la plaza con la colocación de la estatua ecuestre de Simón Bolívar.
} 
of the city is perhaps best epitomized by its monuments, which are deeply rooted in the social and individual mind" (132). Desde este punto de vista, demoler la antigua plaza y el mercado en su totalidad equivalía a borrar uno de los pocos elementos del imaginario citadino y nacional que con tanto ahínco se había pretendido construir al alcanzar la independencia de España. Sin embargo, Javier Lasarte afirma que es este proceso de restructuración y modernización del gobierno de Antonio Guzmán Blanco lo que propicia la fabulación de la tradición (181) por parte de Bolet Peraza, equiparando así su trabajo al de Ricardo Palma con sus tradiciones en Perú.

Eva María Valero señala que una de las cualidades de las Tradiciones peruanas de Palma es la fundación literaria de la Lima mítica del pasado; “es decir, la constitución de un corpus literario en el que la ciudad de Lima, colonial y republicana adquiere la resonancia de un espacio espiritual fundado y fijado en la memoria colectiva del pueblo limeño" (11). Es cierto que los Cuadros caraqueños de Bolet Peraza no llegaron a ser tan numerosos como las tradiciones de Palma; no obstante, cumplen la misma función en la literatura venezolana que los textos de Palma en el Perú ya que recuperan temas y espacios citadinos históricos silenciados durante los años republicanos en un intento por alejar la nueva nación del pasado colonial español. Diego de Lozada fundó Caracas, desde un punto de vista geográfico, en el siglo XV, pero es Nicanor Bolet Peraza a finales del siglo XIX quien le dio un espacio literario concreto a la capital venezolana por primera vez.

Con todo, no se debe confundir el tono melancólico que usa Bolet Peraza en sus textos para hablar de la Caracas de antaño con una actitud contraria al progreso por parte del autor. El tono melancólico viene más bien de la idea de progreso para la ciudad que tenía Bolet Peraza la cual no siempre coincidió con las gestiones de Guzmán Blanco que 
buscaron hacer el progreso visible a través de renovaciones de edificios y monumentos inspirados en la arquitectura francesa de la época. ${ }^{38}$ De la lectura de El mercado se puede deducir que el progreso para Bolet Peraza no equivalía a borrar el pasado sino a incorporarlo. Esta idea no fue exclusiva del escritor venezolano; Benjamin Vicuña Mackenna, quien llegó a ser intendente de la ciudad de Santiago de Chile, consideró a la ciudad de Edimburgo en Escocia como modelo perfecto de ciudad debido a su balance entre lo viejo y lo nuevo y entre la naturaleza y la civilización (Conway 28). En conclusión, tanto los textos de José María Vergara y Vegara como el de Nicanor Bolet Peraza demuestran, una vez más, esa ambivalencia que presentaron términos como progreso y civilización a lo largo del siglo XIX entre los intelectuales latinoamericanos.

\section{Conclusión: la dimensión literaria de la experiencia urbana}

De la muestra anterior puede deducirse que la imagen de la ciudad en el costumbrismo latinoamericano proyectó posiciones irreconciliables acerca de los tópicos del momento. Obras como Museo de limeñadas de Ramón Rojas y Cañas ofrecieron el escarnio a las costumbres incivilizadas urbanas como método infalible para alcanzar la modernidad; no obstante, los límites entre civilización y barbarie no quedan del todo claros en otros cuadros -como Un llanero en la capital de Daniel Mendoza u obras como Lima, apuntes históricos, descriptivos, estadísticos y de costumbres de Manuel Atanasio Fuentes- donde ciertos elementos citadinos son tachados de bárbaros y algunos rasgos

\footnotetext{
${ }^{38}$ Al respecto señala Carmen Michelena: "El principal propósito de las políticas de Guzmán Blanco iba dirigido a demostrar al país y al mundo el progreso al que él mismo habría de conducirlo, un claro ejemplo son las festividades del Centenario del Natalicio del Libertador en 1883, las cuales sirvieron de justificación para lucir la incansable actividad de su gobierno en las tareas transformadoras: en obras públicas y de ornato, en pomposidad y despilfarro fruto de su inclinación por vivir a la zaga de Francia que lo trastornaría todo, incluso el Erario público" (310).
} 
tradicionalmente calificados como incivilizados son revalorizados. Por otro lado, textos como Contratiempos de un viajero de Juan Manuel Cagigal cuestionan de forma abierta la posibilidad de implantar la modernidad en las aún caóticas e incipientes urbes latinoamericanas; mientras que cuadros como El lenguaje de las casas y Las tres tazas de José María Vergara y Vergara y El mercado de Nicanor Bolet Peraza retan el proyecto oficial de modernización al rescatar costumbres y elementos arquitectónicos de los centros urbanos coloniales ignorados por las nuevas repúblicas. La añoranza de los costumbristas por otro espacio más civilizado (el referente con el que se mide es siempre París) deviene poco a poco en una nostalgia por otro tiempo (la Colonia) considerado como más propio (Lasarte 181).

El éxito del costumbrismo en Latinoamérica se debió, en parte, a la necesidad de autodefinición de las nacientes repúblicas que buscaban identificar y describir los aspectos que constituían la experiencia nacional (Watson 11). No obstante, estos esfuerzos, dirigidos siempre desde la ciudad, no estuvieron exentos de incongruencias ya que lo considerado autóctono residía en el campo, espacio calificado como bárbaro y contrario a los nuevos ideales republicanos de civilización y progreso, encarnados solo en las urbes. Las ciudades, por otro lado, eran lugares cosmopolitas y durante la Colonia habían constituido espacios españoles y por tanto extranjeros. Irónicamente, durante el siglo XIX el discurso de nacionalidad fue emitido desde el espacio menos autóctono del país y a través de un género como el costumbrismo que encarnaba una contradicción similar a la del espacio urbano al 
ser "de génesis extranjera, pero de praxis nacionalizadora" (Soriano y Martínez Pinzón 11). ${ }^{39}$

Los cuadros de costumbres ilustraron muchos de los cambios arquitectónicos y de costumbres que sufrieron las ciudades y sus habitantes durante el proceso de modernización; pero más que esto, se ocuparon de las tensiones que tales cambios instauraron en la sociedad. Burton Pike asevera que son precisamente estas contradicciones las que promueven la fascinación del hombre por la urbe real y por la ciudad literaria ya que ambas encarnan sentimientos de orgullo, amor, ansiedad y odio hacia la civilización y la cultura que el entorno urbano genera (26). De allí que las ciudades, las capitales en particular, hayan sido un tema tan prolífico a finales del siglo XIX y principios del XX. Estas tensiones y líneas de cuestionamientos presentadas en el retrato costumbrista de las ciudades fueron retomadas y ahondadas por novelistas como Lucio Vicente López, Miguel Eduardo Pardo, Federico Gamboa, Manuel Díaz Rodríguez, Ángel de Campo, Luis Pascarella, entre otros que hicieron de sus respectivas ciudades el centro narrativo y argumentativo de sus textos.

La relevancia histórica y política de las capitales latinoamericanas explica, en parte, su protagonismo casi exclusivo dentro del costumbrismo latinoamericano. ${ }^{40}$ José Luis Romero afirma que en Latinoamérica "las ciudades y especialmente las capitales han desempeñado un papel de tal importancia que con frecuencia ha permitido confundir su

\footnotetext{
${ }^{39}$ Para leer acerca de la relación entre el localismo y el cosmopolitismo en el cuadro de costumbres consultar "El costumbrismo cosmopolita: deuda, producción de pueblo y color local en el siglo XIX" de Felipe Martínez Pinzón.

${ }^{40}$ Hubo algunas excepciones; por ejemplo, el costumbrista venezolano José María Rivas no se concentró en Caracas, sino que se dedicó a escribir sobre las costumbres de la ciudad de Maracaibo (la segunda más grande del país). Sus textos están recopilados bajo los siguientes títulos: Flores de pascua, Gaitas marabinas y Costumbres zulianas.
} 
historia con la del país al que pertenecen" ("La ciudad latinoamericana..."297). Los cuadros de costumbres constituyeron un arma ideológica a través de la cual se pretendió crear, expresar y promover "la cultura nacional" (Ruiz 75) y, en el siglo XIX, "lo nacional" (entendido también como lo civilizado y lo moderno) fue guiado y establecido desde la ciudad por las élites criollas. Palabras como museo, guirnalda, biblioteca o álbum aparecieron con frecuencia en las colecciones de textos costumbristas de la época en un intento por armonizar, al menos desde el punto de vista retórico, los fragmentos textuales con los que se construía la nación (Soriano y Martínez Pinzón 18).

Con los costumbristas la experiencia urbana en Latinoamérica adquirió dimensión literaria. Como señala Julio Ramos: "the urban subject experiences the city not only because s/he walks through entirely delimited areas, but also because $\mathrm{s} / \mathrm{he}$ reads it in a newspaper that collects and narrates the city's distinct fragments" (124). La Lima, Bogotá y Caracas de los costumbristas es obra de la ciudad letrada cuyos integrantes (entre los cuales se encontraban Cagigal, Rojas y Cañas, Mendoza, Fuentes, Vergara y Vergara y Bolet Peraza) son los únicos capaces de conservar y proyectar la ciudad más allá de su ejecución material (Rama 38). Leer sobre Lima, Bogotá y Caracas se convirtió para los latinoamericanos en experiencia de auto reconocimiento y escribir sobre estas capitales se hizo sinónimo de crear nación. 


\section{CAPÍTULO II}

Entre la ansiedad y el cuestionamiento: cambios urbanos, nueva fauna citadina y crisis de valores en La gran aldea de Lucio Vicente López y Todo un pueblo de Miguel Eduardo

\section{Pardo}

Para los escritores latinoamericanos posteriores a las guerras de independencia, la ciudad se erigió como espacio utópico moderno y civilizado desde el cual pensar y conceptualizar esa nación constituida por territorios mayoritariamente rurales $\mathrm{y}$, por extensión, bárbaros. Digo utópico porque para mediados del siglo XIX las ciudades latinoamericanas distaban mucho de las urbes modernas europeas que pretendían imitar. Fue a partir de 1860 que la materialización, al menos desde el punto de vista físico, de la tan ansiada modernidad se comenzó a hacer visible a través de las renovaciones arquitectónicas llevadas a cabo en las capitales. La literatura del momento ilustró muchos de estos cambios, pero más que esto, se ocupó de las tensiones que tales transformaciones instauraron en la sociedad. Y es que estas renovaciones destruyeron a nivel simbólico los sistemas tradicionales de representación creando conflictos en los grupos sociales identificados con las instituciones, íconos y/o espacios que la racionalización moderna y urbana deshizo a golpe de decreto (Ramos, 160).

La historiografía tradicional latinoamericana popularizó la idea del paso ansiado y fluido de las jóvenes repúblicas a la modernidad. Sin embargo, la imagen de ciudad que se presenta en novelas como La gran aldea (1882), del argentino Lucio Vicente López, y Todo un pueblo (1899) del venezolano Miguel Eduardo Pardo, no solo desmiente esta aproximación, sino que también expone aspectos contradictorios presentes en el proceso 
de modernización de Buenos Aires y Caracas respectivamente. ${ }^{41}$ En este capítulo estudio cómo el extrañamiento ante la urbe moderna, expuesto en los textos mencionados, lleva a un cuestionamiento tanto de la posición de Latinoamérica dentro de la modernidad occidental como de la efectividad y viabilidad del proyecto modernizador y las consecuencias que este trajo consigo.

\section{La gran aldea: la ciudad y la novela de costumbres}

Lucio Vicente López publicó los primeros capítulos de La gran aldea en forma de folletín en el diario Sud América en 1882 y, posteriormente, la historia completa en formato de libro en 1884. La novela narra en primera persona la vida de Julio Rolaz, desde su infancia hasta su adultez. Rolaz, quien queda huérfano a los diez años, vive en una Buenos Aires provinciana junto a sus tíos Medea y Ramón. Medea es descendiente orgullosa de la clase patricia argentina y en su hogar Julio se codea con las mentes brillantes, formadoras de nación, de mediados del siglo. Rolaz sale de Buenos Aires (aunque no de Argentina) para completar su educación secundaria; a su retorno apenas es capaz de reconocer a la ciudad y a sus gentes quienes se han enganchado con obsesión al tren del progreso y la modernidad. Medea muere y Ramón, heredero de las riquezas familiares de su esposa, contrae matrimonio de nuevo con una joven, Blanca Montifiori, mucho menor que él e interés amoroso inicial de su sobrino Julio. Blanca es hija de inmigrantes que hicieron fortuna en Argentina y representa la nueva clase burguesa emergente bonaerense. La disparidad de edades, de costumbres y de valores condena al nuevo matrimonio al fracaso,

\footnotetext{
${ }^{41}$ Ambas obras comparten el haber sido las únicas novelas escritas por sus respectivos autores, así como el haber inaugurado el género de novelas de ciudad en Argentina y Venezuela.
} 
cuestión que se concreta al final del texto con la muerte en un incendio, y debido a la negligencia de la madre, de la única hija de Ramón y Blanca.

Como se desprende del título de la obra, la gran protagonista del texto es la ciudad. La gran aldea puede ser clasificada como un coming of age story ya que en ella el personaje principal narra su paso de la niñez a la adultez. No obstante, ese crecimiento no es exclusivo del protagonista; también Buenos Aires crece y pasa de ciudad poscolonial a metrópoli moderna. En este sentido, Julio Rolaz funciona como una especie de cronista de esa metamorfosis y su particular historia familiar es consecuencia de estos cambios. De esta manera, el coming of age del personaje queda ligado al comming of age de la urbe.

La ausencia de Julio de la capital durante sus estudios intensifica el contraste de las transformaciones urbanas (tanto arquitectónicas como sociales); por esta razón, a su regreso, el protagonista se dedica al nuevo pasatiempo moderno: flanear las calles. En este caso, la actividad no es solo recreativa (de hecho, Julio tiene un concepto negativo de la misma), sino que responde más bien a una necesidad de autorreconocimiento, tanto del personaje como de los lectores de la novela. Dorde Cuvardic señala al respecto: "El deambular del flâneur y su promoción en las representaciones culturales fue una táctica que tuvo el hombre burgués para comprender (hacer legible) y 'familiarizarse' con un espacio urbano que se estaba convirtiendo en ajeno, ominoso" (69). Y es que, a partir del regreso de Julio a Buenos Aires, la acción narrativa de La gran aldea coincide con el presente de los consumidores de la novela (1883-1884) quienes están viviendo y leyendo los cambios urbanos de forma simultánea. Por ejemplo, en 1883, Torcuato de Alvear, el primer intendente de la recién federalizada ciudad de Buenos Aires, inició una de las reformas más significativas de la capital argentina y primer paso para el ensanche de la 
ciudad: la demolición de la Recova de la Carne, sitio de venta de distintas mercaderías y símbolo por excelencia de la antigua ciudad colonial. ${ }^{42}$ Esta reforma unió las plazas de la Victoria y del Fuerte para formar la actual plaza de Mayo. ${ }^{43}$ La gran aldea no aborda de manera explícita esta demolición; no obstante, sí hace referencia a los cambios en la sociabilidad urbana que esta transformación supuso a través de la comparación de los paseos que Julio hacía en su niñez con la tía Medea y los recorridos que hace solo en su adultez. El protagonista se dedica a las siguientes reflexiones durante una de sus caminatas: Hombres y libros nuevos dirijian el pensamiento argentino (...) el gusto, el arte y la moda, habían provocado una serie de exigencias sin las cuales la vida social era imposible (...) la aldea de 1862 tenía muchos ribetes de ciudad (...) No era chic hablar español en el gran mundo; era necesario salpicar la conversación con algunas palabras inglesas, y muchas francesas (...) yo había conocido aquel Buenos Aires de 1862, patriota, sencillo, semitendero, semicurial, semialdea, me encontraba con un pueblo con grandes pretensiones europeas que perdía su tiempo en flanear por las calles y en el cual ya no reinaban generales predestinados (142-144).

\footnotetext{
${ }^{42}$ La idea de demolición de la Recova data de 1869; no obstante, los costos de las múltiples guerras civiles hicieron que el proyecto no se concretase. La federalización de la ciudad de Buenos Aires garantizó la entrada de un flujo significativo de dinero producto, entre otras cosas, de las rentas portuarias que pasaron a ser administradas únicamente por la ciudad. Este capital fue utilizado por Torcuato de Alvear, con la bendición del entonces presidente Julio Argentino Roca, en el ensanche, la infraestructura y el ornato urbano. Alvear fue una especie de Haussman bonaerense. También se ocupó de dar forma a la nueva maquinaria burocrática urbana que nació con el nombramiento de Buenos Aires como capital de la república. Instauró oficinas como la Oficina de Estadística o la Oficina de Obras Públicas. Alvear murió en 1890 y en 1900 la ciudad le dedicó un homenaje que, entre otras cosas, representa en bajorrelieve tres de las obras llevadas a cabo durante su gestión: la apertura de la avenida de Mayo, el arreglo de la Recoleta y la pavimentación de la ciudad.

${ }^{43}$ Este proceso se extendió durante casi un año pues el arco central de la Recova pertenecía a la municipalidad; pero, la familia Anchorena, familia patricia y terrateniente, eran los dueños del resto del edificio y se negaron a destruirlo. Se inició entonces un juicio de expropiación que ganó el nuevo intendente. La Recova terminó de ser demolida en 1884.
} 
Del fragmento anterior se desprende la posición crítica del protagonista hacia los supuestos cambios modernos los cuales no considera promotores del progreso. A sus ojos Buenos Aires sigue siendo una aldea grande solo que ahora tiene algunos rasgos superficiales de ciudad. Hay, sin embargo, en las reflexiones de Julio un dejo nostálgico por aquella Buenos Aires más aldeana en la que creció:

Las tiendas europeas de hoy, híbridas y raquíticas, sin carácter local, han desterrado la tienda porteña de aquella época, de mostrador corrido (...) ¡Cuán lejos están los tenderos franceses y españoles de hoy de tener la alcurnia y los méritos sociales de aquella juventud dorada, hija de la tierra, último vástago del aristocrático comercio al menudeo de la colonia! (...) aquella era buena fe comercial y no la de hoy, la enorme vidriera engolosina los ojos sin satisfacer las exigencias del tacto (65-66).

La ciudad constituye entonces el campo de batalla donde se libra la guerra entre los valores de la tradición y de la modernidad. Los primeros son defendidos por la antigua clase patricia, encarnada en la figura de Medea Berrotarán y los segundos son enarbolados por la clase burguesa representada por Blanca Montifiori. La caracterización del famoso Club del Progreso como espacio predilecto para estudiar la superposición de costumbres y de 30 años de la vida social bonaerense (170) revela además la rapidez y violencia de los cambio sociales, económicos y políticos que sufrió la sociedad argentina -y la latinoamericana en general-, y los conflictos que se desataron al tratar de asimilarlos. ${ }^{44}$

\footnotetext{
${ }^{44}$ El Club del Progreso se fundó en 1852 y el primer baile que aparece retratado en La gran aldea se celebra en 1882. El Club del Progreso fue fundado como una agrupación con fines políticos y económicos; no obstante, se convirtió con el tiempo en un símbolo de la vida social moderna bonaerense.
} 
Términos como aristocracia y burguesía pueden resultar confusos dentro del contexto latinoamericano. ${ }^{45}$ En la mayoría de los países europeos occidentales existió una diferenciación más o menos concreta entre ambas clases: la aristocracia, de origen más antiguo, conservaba su posición en base a un carácter de nobleza hereditario; mientras que la burguesía, que se formó durante la baja Edad Media (entre los siglos XI y XV aproximadamente), adquirió su estatus a partir de la tenencia de propiedades y de capital. Estas clases no eran por supuesto homogéneas; existía la alta y la baja nobleza y la alta y baja burguesía. En todo caso, llegado el siglo XIX ya ambas clases habían comprendido la necesidad de unirse para apuntalar y conservar su posición social. A pesar de la tendencia elitista de la aristocracia, los matrimonios por conveniencia entre individuos de ambas clases fueron bastante comunes. A través de ellos la aristocracia ganaba capital y la burguesía títulos nobiliarios.

En Latinoamérica no hubo nobleza al estilo europeo. Una vez concluida la conquista, la cima de la escala social colonial estuvo ocupada por los conquistadores y su descendencia; no obstante, la mayoría de estos individuos eran de origen no aristocrático y relativamente humilde. Un sinnúmero de hombres se lanzó a la conquista de América ante la oportunidad de mejorar su situación económica y social; muchos consiguieron el primer objetivo, pero tan solo unos pocos recibieron títulos nobiliarios de parte de la Corona Española como recompensa por sus esfuerzos. ${ }^{46}$ Por tanto, la "hidalguía" de estos

\footnotetext{
${ }^{45}$ A pesar de caracterizar a los dos grupos sociales de manera muy clara, Lucio Vicente López utiliza estos términos de forma casi intercambiable en La gran aldea.

${ }^{46}$ Guillermo Céspedes del Castillo indica que la Corona Española evitó la creación de una verdadera aristocracia americana al extender al nuevo continente la nobleza castellana. Así, los reyes mantuvieron por muchos años a la élite del Nuevo Mundo controlada y subordinada a su mando (477). También contribuyó a esto el hecho de que se crearan y concedieran un número muy reducido de títulos de nobleza
} 
primeros "aristócratas americanos" estuvo basada, más que en un linaje familiar reconocido, en el papel jugado en la conquista y/o fundación de ciudades, en la tenencia de encomiendas y/o en el desempeño de cargos públicos en el sistema colonial. Por ende, el atractivo de los títulos nobiliarios para los criollos latinoamericanos residía más en el prestigio y distinción social que brindaban y no tanto en posibles ventajas de tipo material. Por esta razón, la nobleza no llegó a constituir una clase social aparte, sino más bien una condición de éxito adquirido dentro de las élites locales (Büschges 124-125).

Con o sin títulos nobiliarios, durante las primeras décadas de la era republicana, los descendientes de las élites criollas se sintieron poseedores de una especie de nobleza moral y superioridad social por ser los sucesores de los fundadores de las ciudades (los conquistadores españoles) y/o de los padres de la patria (de aquellos criollos que iniciaron y concretaron la gesta independentista o que se involucraron en las subsecuentes guerras civiles). Este es el caso del personaje de Medea Berrotarán. La burguesía latinoamericana, por otro lado, estuvo constituida por un grupo de origen diverso pero que tenía en común una significativa bonanza económica. Por todo lo anterior, para los fines de este estudio distinguiré ambas clases en el marco latinoamericano como lo propone Juan Pablo SpicerEscalante: en base a valores sociales distintos y en ocasiones incompatibles (331).

Como bien señala Paulette Silva Beauregard, es a través de datos paratextuales como el subtítulo- que las novelas de fin de siglo intentan entregar lineamientos para su recepción al tiempo que muestran una voluntad de integrarse a las discusiones que se mantienen en el campo de las letras (42). En este caso, la primera edición de la novela de

latinoamericanos, el más conocido quizás sea el marquesado del Valle de Oaxaca otorgado por Carlos I de España a Hernán Cortés en 1529. 
López se publicó con el subtítulo de costumbres bonaerenses. Este subtítulo emparenta La gran aldea con los roman de moeurs (traducidos al inglés como novel of manners), novelas francesas decimonónicas de corte realista que buscaban dirigir la atención del lector a las costumbres y formas de pensar y valorar de una clase social específica -casi siempre la burguesa. ${ }^{47}$ López abre su novela con una cita del exitoso escritor francés de comedies de moeurs Édouard Pailleron. Este tipo de teatro, popularizado en el siglo XVII por Molière, también abordaba las costumbres y afectaciones de la clase burguesa desde un punto de vista satírico. El epígrafe, tomado de la última obra de Pailleron, Le Monde où l'on s'ennuie, estrenada en 1881, señala lo siguiente:

Qu'on ait trouvé des personnalités dans cette comédie, je n'en suis surpris: on trouve toujours des personnalités dans les comédies de caractère comme on se découvre toujours des maladies dans les livres de médecine. La vérité est que je n'ai pas plus visé un individu qu'un salon; j'ai pris dans les salons et chez les individus les traits dont j'ai fait mes types, mais, ¿où voulait-on que je les prisse? (6).

A Lucio Vicente López le interesaban entonces los salones, es decir, la sociedad como grupo y no los individuos en particular. Pretende presentar personajes "tipos", lo suficientemente generales como para que ninguna persona se sintiese identificada (y ofendida); pero, a la vez, bastante específicos para que la sociedad bonaerense se viese reflejada. En 1886 Martín García Mérou, un contemporáneo de Lucio Vicente López y

\footnotetext{
${ }^{47}$ El referente europeo más importante de este género es por supuesto Honoré de Balzac y su gran obra $L a$ comédie humaine. Lo más probable es que Lucio Vicente López conociese, al menos parcialmente, las novelas del escritor francés.
} 
novelista y crítico literario de las obras de su tiempo, afirma que en La gran aldea "el autor ha abarcado en un relámpago toda nuestra sociedad contemporánea" (Libros y autores 59). En realidad, López solo retrata en su texto las clases altas: la antigua aristocracia colonial y la burguesía. La visión de García Mérou responde a la voluntad de las clases dirigentes y dominantes del momento de execrar a las clases social y racialmente consideradas como inferiores que no encajaban en el modelo único de civilización. ${ }^{48}$

Resulta curioso que, en una sociedad controlada por hombres, como lo era la latinoamericana a finales del siglo XIX, sean las figuras femeninas las que dominan la trama de La gran aldea. El tío Ramón dista mucho de la imagen tradicional del patriarca latinoamericano decimonónico. De hecho, no tiene ningún tipo de influencia en su entorno y es sometido y manipulado por sus dos esposas. Julio, por su parte, funciona más como un narrador espectador que como un narrador protagonista. Es quien se encarga de registrar la metamorfosis de Buenos Aires; no obstante, tiene poca o ninguna agencia sobre estos cambios. La figura de Ramón y de Julio son de cierta manera las bisagras que unen las historias de Medea y Blanca que a su vez encarnan las dos versiones de la capital argentina. Al respecto señala David William Foster: "While that world (Buenos Aires) is not dominated by the Medeas and the Blancas, for Julio it is mediated and interpreted by them at the expense of the male figure (Ramón) whom he believes to be his legitimate point of reference" $(84) .{ }^{49}$

\footnotetext{
48 Esta aproximación de las élites argentinas queda evidenciada de forma explícita en La gran aldea: "Nosotros somos la clase patricia de este pueblo, nosotros representamos el buen sentido, la esperiencia, la fortuna. Fuera de nosotros es la canalla, la plebe, quien impera. Séamos nosotros la cabeza, que el pueblo sea nuestro brazo" (52).

${ }^{49}$ Julio queda huérfano de padre siendo aún un niño; por tanto, Ramón se convierte en su única figura paterna. Si bien le tiene afecto a su tío, Julio está consciente de sus deficiencias como patriarca familiar y en varias ocasiones las pone de manifiesto. A continuación, una cita ilustrativa: "Casada (Blanca) con un truhan, con
} 
La gran aldea está compuesta por veintiún capítulos que se pueden agrupar en dos partes bien diferenciadas: del capítulo 1 al 12, donde domina la figura de Medea, y del capítulo 13 al 21 donde predomina la de Blanca. ${ }^{50}$ Como ya se señaló, ambos personajes son "tipos" (quizás un poco exagerados) de las respectivas clases sociales a las que representan; pero, además, son símbolo de las dos Buenos Aires: Medea de la ciudad poscolonial y Blanca de la metrópoli moderna. En este sentido resulta significativo que Blanca aparezca en la novela por primera y última vez en el ambiente moderno bonaerense por antonomasia: un baile en el Club del Progreso. Medea, otrora anfitriona de las tertulias políticas de mediados de siglo y parroquiana asidua de lo de don Narciso (dueño de la tienda alrededor de la cual la élite se reunía a discutir las novedades del momento), muere de una apoplejía cuando se le niega la entrada a la Sociedad Filantrópica, una de las nuevas agrupaciones de sociabilidad urbana. Al respecto señala Alberto Blasi: "una lectura atenta de la novela muestra que la historia de Julio Rolaz enmarca la de Medea Berrotarán y Blanca Montifiori y que estas sumadas enmarcan la de la ciudad, diosa-madre, Rhea o Cibeles antes y después de la metamorfosis" (172). La asociación de figuras femeninas al suelo, la ciudad o la patria no es novedosa, esta equivalencia está presente en casi todas las mitologías. ${ }^{51}$ En la mayoría de los casos lo femenino implica la reproducción y la

un libertino, pero jóven y con el prestigio propio de un hombre, yo la habria comprendido, pero venderse á un hombre valetudinario (Ramón), á un hombre sin talento, sin espíritu, sin fuerzas (...)” (236).

${ }^{50}$ Hay una pequeña sobreposición en el capítulo 11, donde aparece Blanca por primera vez, y el 12, donde muere Medea. Los dos personajes cohabitan el mismo espacio narrativo (aunque sin interactuar) de manera muy breve pues ambas versiones de Buenos Aires no pueden coexistir, aunque las dos hayan ocupado en algún momento el mismo espacio geográfico.

${ }^{51}$ Por ejemplo, en la mitología griega, Rhea forma parte de la primera generación de titanes y es hija de Gaia, la madre tierra, considerada como la dadora de vida. Rhea a su vez es madre de la primera generación de dioses olímpicos (Zeus, Hestia, Hera, Poseidón y Hades). Desde el punto de vista etimológico, el nombre de Rhea hace referencia a la palabra suelo y en Roma su figura se identificó con la de Magna Mater. Su hija 
maternidad como garantía de continuidad; no obstante, ni Medea ni Blanca son madres (en el sentido más amplio de la palabra). ${ }^{52}$

Medea Berrotarán es la antítesis de la dama aristocrática: “una señora feroz, hija de un mayor de caballería que había servido con Rauch, que había heredado el carácter militar del padre, su fealdad proverbial y un gesto de tigra" (8). Además, era "refractaria por índole y por naturaleza á todo afecto íntimo, y sus caricias debian ser, si alguna vez las hizo á alguien, como una manotada de pantera" (13). Como se desprende de los fragmentos anteriores esta mujer es descrita en términos hombrunos, agresivos y con características y emociones, como la ira y la fuerza, reservadas a los hombres. Es tan poco femenina que Julio la describe como un ser híbrido (109) y señala que por años tuvo dudas sobre su sexo (9). Ramón y Medea no tienen hijos y la culpa de la esterilidad del matrimonio la tiene por supuesto ella: "aquel retoño de los Atridas no dio fruto á pesar de mi tio" (9). El nombre del personaje es además representativo. Medea, en la mitología griega, es la madre desnaturalizada pues asesina a sus hijos en venganza del padre, Jasón, quien la abandona por otra mujer ${ }^{53}$ La Medea de La gran aldea no mata a su descendencia, pero es tan estéril

Hestia fue venerada como la diosa del hogar y como representación de la alianza entre las colonias y las ciudades que las conquistaban. La imagen de Rhea también se relacionó con la diosa de la madre tierra de origen frigio llamada Cibeles. Muchos críticos las consideran incluso la misma figura. La relación entre Cibeles como madre y la ciudad queda clara en monumentos como la famosa plaza de Cibeles en Madrid cuya finalidad inicial fue la de abastecer de agua a los ciudadanos. La escultura de la diosa se instauró en 1782 como parte de una iniciativa de renovación urbanística que se extendió hasta principios del siglo XX. En 1895 se trasladó a su ubicación actual convirtiéndose en un elemento puramente ornamental y emblemático de la capital española.

${ }^{52}$ Me refiero aquí no solo a la que da a luz sino también a la que cría.

${ }^{53}$ Existe una versión de este mito en el que Medea no mata a sus vástagos. Jasón acuerda con Creonte, rey de Corinto, abandonar a Medea para casarse con su hija Glauca. En venganza, Medea envía a la princesa un manto hechizado que se prende en llamas cuando Glauca se lo pone. Creonte intenta salvar a su hija, pero ambos mueren quemados. En represalia, los corintos asesinan a los hijos de Medea y, por esta razón, son castigados con una epidemia que cae sobre la ciudad y que merma la población infantil. Los corintos, aconsejados por el oráculo de Delfos, ofrecen sacrificios a los hijos de Medea para acabar con la maldición. 
que es incapaz de ningún sentimiento materno. Acoge a regañadientes en su casa a su sobrino Julio ante las súplicas de Ramón; no obstante, jamás se convierte en una figura materna para el niño recordándole en todo momento que su presencia en su hogar es un acto de caridad:

-Mira Medea: es el hijo de mi pobre hermano, lleva mi apellido como tú. No tenemos hijos ... ¿Qué cosa más natural que lo hagamos nuestro hijo, que lo eduquemos conforme á nuestros medios?

-Ca! No me muelas la paciencia, Ramon, no me impacientes, -contestaba mi tia Medea furiosa. - Yo no necesito de tu nombre para nada! Guárdatelo, que para nada me sirve! Yo me llamo Berrotarán y Ud. es un pobre diablo, hijo de un lomillero. (31)

Medea Berrotarán asesina simbólicamente la posibilidad de tener una relación filial con Julio y, en ese sentido, se iguala a la Medea griega de quien recibe su nombre. Por otro lado, reniega de su estatus de esposa. A pesar de que no rompe sus votos matrimoniales, el rechazo al apellido del esposo determina la imposibilidad de lograr una unidad familiar.

Blanca Montifiori, al contrario de Medea, es joven, hermosa, sociable y simpática. No obstante, y a pesar de su feminidad física, Blanca también posee rasgos considerados masculinos y censurados en una mujer decimonónica. No es sensible ni sentimental, como cabría esperar, sino fría y calculadora. Julio dice de ella: "yo le había cobrado una innata

\footnotetext{
Algunos críticos consideran que la famosa obra de teatro de Eurípides titulada Medea fue encargada por Corinto al dramaturgo para que atribuyera los asesinatos a la protagonista y así lavar la imagen de la ciudad. Esta aproximación es plausible ya que la figura de Medea resulta contraria al prototipo de mujer de la época y comparte con otros personajes femeninos conflictivos de la mitología griega/romana, como Hécate, Calipso o Circe (de quien es sobrina), su condición de mujer autosuficiente. De hecho, Jasón y los argonautas jamás hubiesen podido completar su periplo y obtener el vellocino de oro sin la intervención de Medea.
} 
repugnancia; porque al fin, aquella mujer era una mujer de mármol, una mujer sin alma, sin sentimiento, sin poesía siquiera" (256). Blanca descarta a Julio (quien no tiene grandes riquezas ni padres) como posible pretendiente y se casa con Ramón, una vez que este hereda la fortuna de Medea, con el objetivo único de avanzar su posición social y económica. Considera el matrimonio como un contrato en el cual el amor no tiene por qué tener protagonismo. ${ }^{54}$ En este sentido su nombre, que en las novelas románticas se utilizaría para hacer referencia a la pureza de la heroína, resulta irónico. Blanca puede procrear y le da una hija a Ramón; sin embargo, y al igual que Medea, es incapaz de ser madre y de cumplir su rol de esposa. Además de ignorar a su hija rompe sus votos matrimoniales pues

${ }^{54}$ El matrimonio de Blanca y Ramón es propiciado y apoyado por los padres de la joven que ven ventajas económicas y sociales para toda la familia en dicha unión. A finales del siglo XIX los matrimonios arreglados, que presentaran ventajas para uno o ambos contrayentes, eran bastante comunes. La realidad es que muy pocas personas (a menos de las clases altas), y las mujeres en especial, tenían la opción de casarse por amor o por voluntad propia (como se concibe hoy en día). El altar o el convento eran las únicas dos opciones para una mujer como Blanca. Cabría preguntarse por qué la trama de La gran aldea es tan dura con un personaje que no hace más que seguir las convenciones de la época. Es posible que la censura a las acciones de Blanca esté justificada por su concepto del amor:

-(...) y la fortuna es hoy indispensable en Buenos Aires. Sin fortuna la vida debe ser abominable. Al menos, yo no la concibo.

- ¿No cree usted en el amor...?

- ¿Solo? Me observó vivamente.

-Sí, le dije mirándola con fijeza.

-Nó! Me contestó ella con indiferencia (...) Yo soy una mujer rara, extraña. Yo no he amado nunca (...)

-Es triste, le repliqué; ser de un hombre a quien no se ama, debe ser algo terrible en la vida.

-No lo creo (...) Yo no sé si algún dia me enamoraré, pero si tal cosa sucediera, soltera ó casada, yo seguiría el imperio de mis pasiones...

- ¿Casada también? ...le pregunté, aproximándome todo lo más posible.

—Casada, también! Me contestó (...) (1193-195)

Si bien los matrimonios arreglados, sin amor, eran prácticas sociales comunes; en la literatura latinoamericana del momento el amor era utilizado como una ley común e ineludible que se sobreponía, al menos de forma retórica, a las fragmentaciones sociales, políticas, económicas y raciales propias de las nuevas repúblicas (Sommer 43). No obstante, este amor solo era provechoso para la nación dentro del contexto del matrimonio. De allí, que la mayoría de los llamados romances nacionales terminen con las nupcias y/o la descendencia de los protagonistas enamorados. Como se desprende del fragmento anterior, Blanca concibe el amor como un elemento independiente que puede o no estar presente en el matrimonio y al cual se rendiría estando casada o soltera; esto implica la posibilidad latente de romper los votos matrimoniales. Este tipo de amor no lleva a la consolidación familiar como representación de la nacional y por ello debe ser censurado para que se convierta en una advertencia a las lectoras que pretendan seguirlo. 
se enreda con varios amantes. En su caso el problema no es la esterilidad sino la superficialidad pues prefiere la vida nocturna del club y el teatro que la vida del hogar:

De repente una puerta se abría, un ruido de sedas cuyo frou frou, creeríase el pasaje de un duende, dejábase oir en la habitación y á través de la media luz azulada del velador, el pobre viejo, enfermo y postrado (Ramón) veía atravesar como un fantasma, la silueta fascinante de Blanca, arrastrando ondas de rasos y encajes y dejando á su paso el perfume capitoso de juventud (...) aquella aparición deslumbrante de todas las noches, que pasaba indiferente por su lado y el de su hija, que no rendía culto ni á la ley del esposo ni al cariño de la madre, que volvía llena y tibia aun con los vapores del mundo en que vivía, después de librar la batalla del lujo en la feria de las vanidades $(\ldots)(280-281)$

Doris Sommer propone que en la literatura latinoamericana del siglo XIX la metáfora del matrimonio se transforma en una metonimia de consolidación nacional ya que acorta distancias regionales, económicas y partidistas (35). El matrimonio del tío Ramón con Blanca Montifiori puede ser leído como un intento de unión en términos urbanos entre la antigua aristocracia y la burguesía emergente. La concreción de dicha posibilidad está representada en la hija de ambos. Desde este punto de vista, las costumbres cosmopolitas y extranjerizantes de Blanca aniquilan lo tradicionalmente argentino encarnado en el tío Ramón y, a la vez, la posibilidad del porvenir de la urbe y de la nación representada en la niña. No obstante, la imposibilidad de futuro aparece desde el primer matrimonio del personaje. Medea se siente superior a Ramón por ser hija de un mayor de caballería que participó en las guerras civiles mientras que él es hijo de un comerciante de arneses, lazos 
y riendas para el ganado. Ambos son blancos criollos, pero provienen de subgrupos social y económicamente diferentes. La imposibilidad de unión de ambos sectores queda evidenciada en la esterilidad del matrimonio y en la muerte de Medea y la catatonia de Ramón. Ninguno de los dos logra adaptarse a los cambios que sufre la ciudad que los vio nacer y por esta razón la trama de la novela los descarta.

Ambos matrimonios del tío Ramón, como patriarca familiar (aunque sea una figura risible), resultan en uniones absurdas que más bien acrecientan las diferencias e imposibilitan la familia como fin común y base de la sociedad. El propio Ramón reconoce su fracaso: "Yo debo decirte que no sé qué ha sido peor para mi, si mi vida pasada de casado, ó mi vida presente (...) que no sé cuando hé sufrido más, si en la guerra viva de la primera época ó en la fiesta perpetua en que vive todo lo que rodea á mi suegro (...)”(284). Esta queja del personaje encierra a su vez el lamento del ciudadano decimonónico que no sabe si es mejor vivir en la artificialidad de la Buenos Aires moderna o en la ciudad aldeana perpetuamente azotada por las guerras civiles posindependentistas. El fracaso de los matrimonios representa la inviabilidad de la unión tanto de clases sociales con valores opuestos como de rasgos contrarios en la urbe y, en este sentido denuncian la inefectividad del proyecto de modernización de las élites liberales rioplatenses.

Lucio Vicente López (1848-1894) pertenece a lo que se conoce en la historiografía argentina como la generación del 80. Con este nombre se denomina a la élite que dominó la política, economía y cultura argentina entre 1880 y $1916 .{ }^{55} 1880$ fue un año

\footnotetext{
${ }^{55}$ Este término apreció en el siglo XX y fue utilizado por diferentes historiadores y críticos, como Arturo Giménez Pastor o Manuel Mujica Lainez, para referirse tan solo a los escritores de este período; los cuales en su mayoría fueron también políticos cuestión que facilitó la eventual extensión del término a todos los intelectuales y dirigentes de la época. El propio Lucio Vicente López llegó a ser interventor federal de la provincia de Buenos Aires de 1893 a 1894 y ministro del interior en 1893.
} 
significativo, entre otras cosas, porque fue aprobada por el congreso la federalización de Buenos Aires y ascendió a la presidencia Julio Argentino Roca, artífice de la Conquista del Desierto, campaña militar que logró anexar al territorio nacional grandes extensiones de terreno ocupadas por distintas tribus autóctonas de la zona (mapuche, pampa, ranquel, entre otros). Esto significó el triunfo tanto de la civilización sobre las consideradas bárbaras comunidades y culturas indígenas como el de Buenos Aires, que se erigía como portaestandarte del progreso moderno, sobre las provincias al por fin convertirse en la capital de la nación y liberarse del gobierno de la provincia en la que estaba geográficamente situada. Además, esta victoria le puso punto y final a años de revoluciones y crisis políticas y significó el inicio de un periodo de relativa paz institucional. De hecho, el lema de las dos presidencias de Roca fue: "Paz y administración”. Esta generación del 80 estuvo caracterizada por defender posturas positivistas y evolucionistas y por su fe ciega en el orden y el progreso como vehículos para alcanzar la modernización del país. En este contexto, Buenos Aires se convirtió en símbolo y receptáculo de la modernidad argentina. Resulta significativo entonces que sea precisamente un miembro de esta generación quien haya cuestionado con su obra no solo la posición de la capital como espacio civilizado sino también la viabilidad del proyecto modernizador.

Los cambios de Buenos Aires en las dos últimas décadas del siglo XIX y las dos primeras del XX fueron tanto urbanísticos como sociales; López, a pesar de hacer referencia a la metamorfosis física, prefiere poner la lupa en las transformaciones sociales de la urbe. Las relaciones interpersonales de los ciudadanos pasaron de estar mediadas por la alcurnia de la familia a la que pertenecían (quién se es) a estar determinadas por los favores políticos y económicos (qué y cuánto se tiene y a quién se conoce). López censura 
ambas modalidades; no obstante, hay un dejo de humor en su crítica a las primeras. Para el momento en que López escribe y publica su texto, estas costumbres y formas de socializar heredadas de la Colonia resultaban ya anacrónicas y se encontraban en declive y a punto de desaparecer. De allí que el personaje de Medea y su forma de actuar sea descrito de manera burlesca:

La otra (Medea) era un fauno obeso; su voz gruesa, su pescuezo corto, su pecho invasor, un bozo récio, que ya era bigote casi, hacían de ella un ser híbrido, en el que los dos sexos se confundían. Estaba esa noche verdaderamente constelada de diamantes (...) como los tenía, y muy buenos, uno de sus orgullos era colgárselos para exhibirlos.

Inquieta y parlanchina mantenía un verdadero telégrafo de saludos con todo el teatro (...) hacía repetidos movimientos de cabeza en dirección al palco central, sin que fuesen notados por sus ocupantes. (109-110)

En este caso el humor es permitido porque las "Medeas" bonaerenses estaban poco a poco desapareciendo. Por el contrario, la censura a los comportamientos de Blanca es siempre seria y está permeada de un tono de advertencia. No hay burla posible pues las "Blancas" dominan la Buenos Aires del momento.

Lucio Vicente López denuncia las deficiencias del proyecto modernizador; no obstante, tiene conciencia de que los cambios son ineludibles. Buenos Aires no volverá a ser lo que fue ni física ni socialmente; es necesario entonces redirigir esta metamorfosis para conseguir un verdadero progreso. En este sentido La gran aldea es un cautionary tale dirigido a las "Blancas" bonaerenses y a aquellos que permiten y hacen posible que su 
estilo de vida domine la capital y, por extensión, el país. La novela cierra con el siguiente aviso:

Pero alguien, con toda la exigencia inexorable de todos los que leen, querrá saber de Blanca. Blanca, la linda porteña, corre la vida fácil y elegante, pero duerme con los ojos abiertos, porque cuando los cierra, la cara de un viejo idiota y paralítico la observa con una sonrisa inmóvil y el brazo rígido de su hija muerta se levanta como una eterna amenaza. (314)

\section{Todo un pueblo: la novela de ciudad naturalista}

Todo un pueblo del venezolano Miguel Eduardo Pardo narra en tercera persona la historia de Julián Hidalgo, joven descendiente de indígenas por la línea paterna y de criollos por la materna. Hidalgo sufre desde la niñez injusticias sociales provocadas, en parte, por su ascendencia indígena cuestión que, unida su carácter, lo hacen desarrollar un carácter rebelde y un rencor creciente en contra de la sociedad urbana en la que vive. De ahí que la imagen de la ciudad que observamos a través de sus ojos esté conceptualizada siempre en términos negativos y amargos. En la adultez Julián se enamora de Isabelita Espinosa, hija de Anselmo Espinosa, personaje representativo de la nueva clase burguesa que aparece en las ciudades a raíz de los cambios económicos.

Anselmo Espinosa, descendiente de inmigrantes pobres, se enriquece a través del comercio y de las especulaciones en la bolsa; no obstante, y a pesar de su dinero, los individuos pertenecientes a la antigua clase mantuana colonial lo desprecian por su carácter de "nuevo rico". Al respecto señala la voz narrativa de la novela: "hubiera dado la mitad de su hacienda a cambio de un nombre sonoro, de un segundo apellido que le diera visos de nobleza. ¡Ah lo que sufría Espinosa recordando a su padre!” (65). Anselmo a su vez 
desaprueba los amores de su hija con Julián debido, entre otras cosas, a la ascendencia indígena del último. Recordemos que, a pesar del discurso de inclusión de los movimientos independentistas y de la voluntad inicial de alejarse del pasado español, las repúblicas latinoamericanas heredaron y apuntalaron la pirámide social colonial en donde la mezcla con indio o con negro equivalía, a ojos de las clases privilegiadas y blancas, a sentenciar a la prole a descender en la escala social. El rechazo del suegro incrementa aún más el rencor de Julián; odio que explota al descubrir los amoríos de Anselmo con Susana, su madre.

Todo un pueblo se publicó en formato de libro en 1899 en Madrid y no en Venezuela. El autor aclara en el prólogo la razón de dicha decisión. Aparentemente, Pardo comenzó a escribir su novela cuando retornó a Caracas luego de una estancia corta en Europa. Antes de que el texto estuviese concluido leyó algunos capítulos en público. Como se desprende del siguiente fragmento (incluido en el prólogo de la novela), su tono satírico causó gran revuelo en la Caracas del momento: “- ¡Pero, hombre de Dios, cuándo sentará usted esa cabeza! ¿Es verdad lo que me han dicho? - ¿Qué le han dicho, amigo mío? -le pregunté asustado. -Que ha escrito usted un libro espantoso, horrible contra la sociedad" (11). Años después, Pardo regresa a Europa y, alejado de esa sociedad que lo atacó y calumnió, culmina y publica el texto que hoy leemos. Pardo utiliza un engañoso tono de víctima en el prólogo de su novela; no obstante, es de suponer que el autor sabía de antemano el impacto que tendría su texto.

Para el momento en que Pardo comenzó a escribir Todo un pueblo, ya era amplio conocedor y usuario de la sátira literaria como arma de escarnio público y crítica social. Es más, en 1892 desempeñó el cargo de director del periódico satírico El buscapié de Caracas. Previendo la reacción de los lectores que se sintiesen aludidos en su texto, Pardo cambia 
de forma estratégica el nombre de Caracas por el de Villabrava asegurando que esta es una ciudad indeterminada como "cualquiera otra ciudad de las muchas que se ofrecen ellas solas a la censura literaria (...) donde las imaginaciones acaloradas por naturaleza, por el medio y por el clima, hacen de sus cosas más vulgares maravillas" (15). Pardo se cuida también de designar cualquier espacio o personaje público por su nombre real. Así, Antonio Guzmán Blanco, conocido como el Ilustre Americano, presidente quien llevó a cabo las mayores renovaciones a la arquitectura y costumbres caraqueñas, pasa en el texto a ser "el tremendo nivelador" (90) y la plaza Bolívar, obra cumbre de la empresa de Guzmán Blanco, se convierte en la "plaza Nueva" (29).

No obstante, y a pesar de las modificaciones mencionadas, Villabrava es claramente Caracas. Sus descripciones son el revés de la imagen dibujada por escritores románticos, como Juan Antonio Pérez Bonalde quien escribió: “¡Caracas allí está; vedla tendida/ a las faldas del Ávila empinado, / odalisca rendida/ a los pies del sultán enamorado" (61). Por el contrario, la misma ciudad es descrita por la voz narrativa de Todo un pueblo de la siguiente manera:

Desigual, empinada, locamente retorcida sobre la falda de un cerro; rota a trechos por espontáneos borbotones de fronda; pudiendo apenas sostenerse sobre los estribos de sus puentes, caldeada por un irritante y eterno sol de verano; sacudida a temporadas, por espantosos temblores de tierra; castigada por lluvias torrenciales, por inundaciones inclementes; bullanguera, revolucionaria y engreída, era Villabrava una ciudad original, con puntas y ribetes de pueblo europeo, a pesar de sus calles estrechas y de sus casas rechonchas, llenas de flores y de moho. 
El modernismo le suprimió lo mejor de sus primitivas costumbres, para darle, en cambio, muchos otros usos de esos que la civilización decreta en todas partes. (89)

La caracterización despectiva de la infraestructura citadina constituye un ataque directo tanto a la modernidad como a la gestión de Guzmán Blanco cuyo proyecto de progreso se concentró en el desarrollo urbanístico y su ornato. Se resalta además el hecho de que los ciudadanos modernos todavía no habían logrado vencer al enemigo número uno de los primeros colonos que se asentaron en el territorio: la naturaleza, que aún sacudía y rompía la estructura urbana. Los terremotos eran además un elemento significativo del imaginario venezolano de la época ya que aún se recordaba con espanto el terremoto de 1812 que destruyó Caracas y otras ciudades como Mérida y Barquisimeto. ${ }^{56}$ Los daños materiales y los fallecidos fueron tantos que se dice que algunos periódicos de la época publicaron artículos recomendando la fundación de una nueva capital. Este terremoto colaboró además con la perdida de la Segunda República retrasando así la independencia del territorio. ${ }^{57}$

\footnotetext{
${ }^{56}$ Se hace referencia a este mismo terremoto en el ya mencionado cuadro de costumbres Contratiempos de un viajero de Juan Manuel Cagigal.

${ }^{57}$ El clero católico, que se encontraba a favor de la Corona Española, calificó el terremoto, que por demás sucedió en un Jueves Santo, como un castigo divino debido a la desobediencia de la población que se había colocado del lado del ejército patriota de Simón Bolívar. Compararon la devastación de Caracas con la destrucción de impías ciudades bíblicas, como Babilonia, causando miedo en la población y ganando así adeptos a la causa realista. En respuesta, Bolívar pronunció un discurso que incluyó una de sus frases más repetidas en la posteridad: "Si la naturaleza se opone, lucharemos contra ella y haremos que nos obedezca". El ensayista ecuatoriano Juan Montalvo describe el suceso de la siguiente manera: "El terremoto de Carácas fue, con todo, golpe mortal para la república no solamente á causa de ruina de ese hogar de fuego sagrado, sino tambien por los sentimientos adversos a la patria que los sacerdotes infundieron en el ánimo de los simples e ingenuos moradores de los campos. El cielo había hecho esa grave demostración, lo cual era condenar las armas de los enemigos del rey" (120).
} 
El último párrafo de la cita alude al conflicto de las clases altas que se debatían entre el tradicionalismo y el cosmopolitismo. En este caso, Pardo identifica lo autóctono, y por extensión lo que vale la pena conservar, con las costumbres primitivas que eliminó la modernidad (al decir modernismo, Pardo no se refiere al movimiento literario que hoy día identificamos con dicho nombre sino a la modernización). No obstante, el fragmento resulta inexacto en cuanto a cuáles costumbres primitivas alude realmente Pardo. Queda la duda de si se refiere a las costumbres coloniales, calificadas de arcaicas por los tiempos modernos, o si habla de costumbres aún más antiguas, quizás propias de las comunidades autóctonas. Esta ambigüedad se mantiene a lo largo del texto.

Se puede concluir entonces que la estrategia retórica de Pardo pretendía ocultar la identidad de Caracas tan solo a nivel superficial. Todo un pueblo es una novela que se circunscribe en el género naturalista por lo que su autor, muy al estilo de Les Rougon Macquard de Émile Zola, quería que la sociedad burguesa viera su hipocresía reflejada en el texto. Es de suponer que Miguel Eduardo Pardo, quien vivió largos años en Europa entre París y Madrid, conociese la obra de Zola. Cronológicamente hablando, la publicación de Todo un pueblo coincide con la época de auge del modernismo (como género literario). No obstante, Pardo apuesta por el naturalismo; a pesar de que para el momento de publicación de su novela la popularidad de dicho género ya iba en declive tanto en Europa como en Latinoamérica. Al respecto, en 1892, el representante más significativo del alienismo europeo, Max Nordau (quien se dedicó a estudiar la supuesta neurosis padecida por los artistas de fin de siglo) señalaba lo siguiente: "the naturalism in France is done with is 
admitted by all the world, and is really only disputed by Zola himself' (473). El escritor venezolano estaba consciente de este hecho por lo que aclara en su prólogo:

Varias obras muy valientes, muy atrevidas, muy pujantes, acaban de salir por ahí, escritas en un lenguaje que busca escándalo; y no han conseguido alborotar a nadie (...) En esas variadas obras y en ciertos determinados capítulos, se toca, aunque incidentalmente, una tesis que tiene algún lejano parentesco con la tesis que constituye, en absoluto mi novela. Consecuencia: si no la publico enseguida, va a resultar fuera de tiesto y pasada de moda (12).

Estas obras atrevidas a las que se refiere Pardo son aquellas que se circunscribían al género modernista. Una de las muchas críticas que recibió Pardo con respecto a su novela fue el lenguaje supuestamente poco trabajado que utilizó para escribirla. Llegados a este punto, resulta conveniente recordar que Miguel Eduardo Pardo fue ante todo un periodista $\mathrm{y}$, en particular, un cronista. $^{58}$ El lenguaje de sus escritos, tanto de sus artículos periodísticos como de su novela, es pragmático y resulta simple solo si se le compara con otros escritores del momento, como Manuel Díaz Rodríguez, que se decantaban por el estilo preciosista del modernismo. La escritura periodística sumada al revuelo que causó las criticas contenidas en Todo un pueblo le valió tanto a la novela como al autor la condena de sus contemporáneos y de generaciones futuras que determinaron que la obra era indigna de ser leída porque estaba mal escrita. Por ejemplo, en 1961, Mariano Picón Salas, uno de los críticos literarios venezolanos más notables, aún caía en el lugar común de sus

\footnotetext{
${ }^{58}$ Entre 1892 y 1894 Pardo mantuvo una columna, llamada Madrileñas, en el periódico El cojo ilustrado en la que publicó una serie de crónicas acerca de sus impresiones de la vida europea.
} 
antecesores al calificar a Todo un pueblo como una novela picante y mordaz, pero de estilo pobre y chabacano (Estudios de ... 150). El modernismo no fue un movimiento uniforme, estuvo caracterizado por una mezcla de doctrinas y de posturas estéticas diversas; no obstante, casi siempre asumió una posición crítica ante los valores de la burguesía. En este sentido, Todo un pueblo sí coincide ideológicamente con el modernismo a pesar de no compartir la forma del lenguaje.

Por otro lado, la preocupación que Miguel Eduardo Pardo muestra en el extracto anterior con respecto a la moda y a no "resultar fuera de tiesto" está relacionada con el valor que se le adjudicó a lo nuevo durante la modernidad. Víctor Goldgel señala que durante esta época la novedad pasó a constituir un criterio de valor positivo (29) y signo inequívoco de mejora (31). Así, el concepto de lo nuevo logró confundirse con el de progreso. Para mantener esta lógica a flote fue necesario convivir con una dinámica de renovación acelerada tanto de la estructura urbana como de los valores y las relaciones sociales. Los cambios constantes implicaban entonces novedades continuas que representaban a su vez el progreso de las naciones. De cierta manera la ciudad se convirtió en el espacio moderno porque en ella se concentraron todas las novedades.

Esta lógica de igualar la novedad con el progreso es la que ataca Pardo cuando describe a Caracas como un pueblo con ribetes de ciudad que apenas puede sostenerse sobre sus puentes; sin embargo, el autor también cae víctima de la misma dinámica que critica ya que la moda y la novedad extendió su área de influencia hasta imponer su lógica en la literatura (Goldgel 25). La mercantilización de la literatura como producto de consumo ya había empezado décadas antes con la invención de la prensa impresa y de las novelas por entrega; no obstante, se aceleró durante las últimas décadas del siglo XIX. Para 
ser leído había que escribir a la moda. De allí la popularidad del modernismo como género ecléctico que admitía en su seno diferentes ideas y estilos convirtiéndose así en una fuente constante de novedades. Del prólogo se desprende que Pardo estaba consciente de esta dinámica de compra y venta en la que se intenta insertar para que su texto sea leído. El naturalismo como género literario podía resultar ya algo anacrónico para los lectores de la época, pero el tema y punto de vista de la obra resultaban novedosos; tanto así que Todo un pueblo inauguró el género de novela de ciudad en Venezuela.

En Todo un pueblo, el carácter tanto del protagonista, Julián Hidalgo, como el de los villabravenses se explica en términos naturalistas desde el prólogo: estos individuos están determinados a ser como son debido a su entorno y a su herencia. El ambiente urbano produce sujetos con ínfulas de europeos y hambre de riquezas que buscan el lucro a través de favores, especulaciones y favoritismo político. El trabajo honesto como medio de superación social y personal no tiene cabida en esta sociedad hipócrita y chismosa. El sol/calor del entorno es además catalizador de los peores impulsos de los ciudadanos. Al respecto, Felipe Martínez Pinzón afirma que las élites colombianas decimonónicas señalaban el calor como el obstáculo principal de ciertas zonas geográficas para alcanzar la civilización (Una cultura... 13). Lo mismo podría afirmarse en el caso venezolano y, particularmente, en la apreciación que del tema tenía Miguel Eduardo Pardo. La diferencia está en que, en Colombia, esta explicación justificaba la superioridad de las zonas altas y de Bogotá, como capital civilizada, sobre el resto del país. Por el contrario, en Venezuela, la misma ideología condenaba a Caracas al atraso ya que la ciudad se ubica en la zona de la costa. La novela se inicia con la siguiente imagen: 
¡Todo arde, todo brilla, todo es luz! Todo parece que palpita y gime bajo los rayos de un sol fogoso y casi bravío que, abriéndose paso a través de las nubes, señorea por los espacios su deslumbradora fiereza. Nada detiene su invasión: después de incendiar la atmósfera llega a la cumbre de la montaña y la montaña adquiere cárdenos resplandores de volcán; hace de la llanura un océano de fuego (...) entra en los patios, en los jardines, en los corredores mismos de las casas, relampaguea_en los tejados; inflama las paredes; arranca vivos, sangrientos centelleos de las piedras del arroyo, y al revolcarse despiadado y frenético sobre la tierra desnuda, la tierra se estremece, abre su seno voluptuoso y exhala un tibio y prolongado soplo de lujuria (29). ${ }^{59}$

Como se desprende de los términos utilizados en la descripción anterior, este sol/ calor es violento e ineludible. Ningún ciudadano puede escapar a él pues permea la ciudad y todos sus espacios. Ni siquiera Isabelita Espinosa, el personaje más ingenuo y mejor intencionado de la novela, se salva de su influencia y es "herida de súbito" (29) por el sol desde la primera página del libro.

La herencia, por su parte, juega un papel diferente en los distintos personajes dependiendo de los elementos que estos recibieron como legado de sus respectivas familias. Sujetos como las Pérez Linaza y las Tasajo, vecinas y amigas de Isabelita Espinosa, están determinadas por las pretensiones e ínfulas de superioridad de la antigua clase mantuana de la que descienden. Por su parte, Anselmo Espinosa, quien es hijo de

\footnotetext{
${ }^{59}$ Las cursivas son mías para resaltar todos los términos violentos utilizados para describir la influencia del sol/calor.
} 
inmigrantes pobres, es descrito siempre en términos peyorativos. Es sucio, bruto (de fuerza y de mollera) y ambicioso sin medida. La voz narrativa concluye que "el odioso proceder de este energúmeno tenía una explicación: su origen” (63). En este tema Todo un pueblo empalma con otras novelas del fin de siglo latinoamericano, como ¿Inocentes o culpables? del argentino Juan Antonio Argerich, publicada en 1884, que ven en el tipo de inmigración que llega a Latinoamérica el problema principal que impide la instauración definitiva de la modernidad. Argerich disipa con rapidez la duda planteada en el título de su novela al afirmar lo siguiente en el prólogo de su texto: "en mi obra, me opongo franca y decididamente a la inmigración menor europea, que reputo desastrosa para los destinos á que legítimamente puede y debe aspirar la República Argentina” (II). Queda claro entonces quienes son los culpables y de qué son culpables. Pardo, por su parte, señala en su novela: “(...) esos inmigrados que llegan de todas partes sucios, andrajosos, maltrechos de cuerpo y de espíritu, pidiendo hospitalidad a veces y a veces trabajo, acabando por llenar de injurias e hijos el país donde se instalan" (63). De estas citas se desprende que, a ojos de un grupo significativo de pensadores latinoamericanos de finales del siglo XIX, los hijos de los inmigrantes estaban condenados a ser una ofensa para las repúblicas modernas que se intentaban instaurar.

A lo largo del siglo XIX, Latinoamérica tuvo una relación ambivalente con la inmigración. Se le deseaba, pues tanto las guerras de independencia como las civiles habían mermado de manera significativa la población de las zonas urbanas y rurales por igual, pero a la vez se le temía por sus posibles repercusiones. Al respecto se cuestiona Anselm Strauss: 
(...) if an urban site were to be abandoned and then later inhabited by an entirely different set of residents. Would this, then, be the "same" city? In a less fanciful instance, whenever American cities are noticeable invaded by new waves of immigrants, the older immigrants understandably enough begin to ask the same kind of question; they begin to wonder whether the city is really the same city in fact -and not merely in name - and to what degree (21).

Con sus textos, Lucio Vicente López y Miguel Eduardo Pardo parecen dar una respuesta negativa a esta pregunta. ${ }^{60}$ Tanto el fenómeno migratorio como las oleadas de cultura, costumbres y valores ingleses y franceses desdibujaron el perfil arquitectónico y social de las antiguas ciudades coloniales creando todo tipo de miedos y ansiedades en los ciudadanos decimonónicos. No obstante, aumentar el número de habitantes era una necesidad primordial para las jóvenes repúblicas latinoamericanas. Juan Bautista Alberdi (1810-1884) lo definió con su famosa frase: "gobernar es poblar" (17). Los inmigrantes eran entonces requisito ineludible para aumentar la población de manera acelerada y así construir repúblicas robustas. Sin embargo, Alberdi aclara:

La única inmigración espontánea de que es capaz Sud América es la de las poblaciones que no necesita: esas vienen por si mismas, como la mala hierba. De esa población puede estar segura América que la tendrá sin llevarla; pues la civilización europea la expele de su seno como escoria (...)

\footnotetext{
${ }^{60}$ El caso de la capital de Colombia es quizás el ejemplo más claro ya que la ciudad cambia inclusive de nombre: Santafé no puede ser Bogotá a pesar de que ambas ciudades hayan ocupado el mismo espacio geográfico.
} 
¿Por qué razón he dicho que en Sud América gobernar es poblar, y en qué sentido es esto una verdad incuestionable? Porque poblar, repito, es instruir, educar, moralizar, mejorar la raza; es enriquecer, civilizar, fortalecer y afirmar la libertad del país (...) Poblar es civilizar cuando se puebla con gente civilizada, es decir, con pobladores de la Europa civilizada (...) Poblar es apestar, corromper, degenerar, envenenar un país cuando en vez de poblarlo con la flor de la población trabajadora de Europa, se le puebla con la basura de la Europa atrasada o menos culta (17-18).

Poblar es entonces una acción dual pues puede implicar la ansiada civilización del país o la degeneración del mismo. El hecho de que Alberdi relacione el concepto de civilizar con el de mejorar la raza denota que la conceptualización de modernidad a finales del siglo XIX implicaba (aunque quizás no a voces) un blanqueamiento (tanto racial como cultural) de la población. En este contexto decimonónico también resulta significativo el uso que hace Alberdi de verbos de carácter patológico como apestar, corromper y envenenar. Recordemos que en el imaginario del siglo XIX y principios del XX higienizar era parte del proceso de modernización. No obstante, para la época, el concepto de enfermedad no solo aludía a las afecciones del cuerpo de quien la padecía; sino que, además, estaba ligado de forma íntima con el orden social establecido. Los inmigrantes quebrantaban este orden pues traían consigo costumbres, lenguas y hábitos diferentes; por esta razón, se convirtieron en el chivo expiatorio al que se le adjudicó las deficiencias que los intelectuales decimonónicos percibían en los intentos de instauración de la modernidad en Latinoamérica. La afrenta era aún peor pues los inmigrantes transmitían estas "deficiencias" a su descendencia. 
En Todo un pueblo, Isabelita Espinosa, es descrita como la antítesis de su padre Anselmo; es bondadosa, cariñosa y comedida. En su persona se conjugan las características típicas de la heroína romántica:

Isabel es algo más que buena; es algo más que bonita: un verdadero prodigio de hermosura. Tiene dieciocho años y tiene, además, para realce de su rozagante y espléndida juventud una infinidad de admirables y sugestivos encantos físicos, tales como sus grandes ojos garzos velados por largas pestañas, su pelo ondeado y rubio, como el oro, sus mejillas frescas y su boca pequeña y húmeda que es un verdadero nido de sonrisas. (34-35)

A pesar de su personalidad, Isabel sigue representando una amenaza puesto que tácitamente es portadora de esos genes degenerados heredados de su familia paterna. De hecho, la voz narrativa especifica que Anselmo era violento con su esposa porque su padre también lo había sido; por consiguiente, sus nietos tendrían el potencial de seguir dicho patrón de conducta. En este sentido, resulta significativo que la novela no termine con el matrimonio o los hijos de la pareja de enamorados.

Por otro lado, en Todo un pueblo la representación de la herencia indígena del protagonista, Julián Hidalgo, resulta ambigua pues, a pesar de hacerlo arisco y rencoroso lo hace también honesto, valiente y decidido. La voz narrativa lo describe de la siguiente manera:

De herencia le venía a Julián Hidalgo el ser levantisco: de los abuelos rebeldes, de aquellos viejos épicos, caudillos de tribus vencidas, a quienes la historia de la conquista negó el valor y regateó el heroísmo, porque no quisieron admitir la civilización a latigazos. 
Insurrectos de esa talla, bravíos guardianes de sus mujeres y sus tierras, fueron los predecesores del primer indio anónimo que apellidó Hidalgo el invasor. El indio sometido pero no domado escondió el odio en no se sabe qué rincón del alma y lo transmitió a sus hijos (...) nació precoz Julián y nació rebelde como nació feo: por atavismos de raza (...) (41).

El contraste entre la descripción física de Isabel y Julián resulta contradictorio dado que al principio de la novela se señala un dato que no se repite en el resto del texto: Julián e Isabel son parientes. La madre de la protagonista, Juana Méndez Hidalgo, es prima del padre de Julián, José Andrés Hidalgo. Anselmo Espinosa accede a casarse con Juana solo porque, y como ya se señaló, fue despreciado por todas las damas de la alta sociedad villabravense debido al origen de sus padres. Julián es feo, "recio y fuerte; trigueño, pronunciadamente trigueño, casi cetrino" (31) mientras que Isabel es rubia, delicada y esbelta como una estatua griega (35). ${ }^{61}$

No es de extrañar que Isabel sea buena y bella ya que en la tradición literaria romántica ambas características son un espejo de la otra. Las protagonistas son bellas porque son buenas y viceversa. Tampoco asombra que Julián, al ser de piel oscura, sea calificado de feo, pero fuerte y vigoroso, pues era un lugar común valorar de manera positiva la fuerza física, más no la apariencia, de las razas consideradas inferiores. Pese a esto, Pardo otorga a Julián la superioridad moral con la que la representación occidental

\footnotetext{
${ }^{61}$ Joan Torres-Pou señala que en la novela latinoamericana de finales de siglo: "era conveniente empezar a presentar tipos criollos de mujer, pero, si el personaje tenía cierta relevancia, era preciso puntualizar que no se trataba de ninguna mestiza" ("Intertextualidad..." 67). En el caso de Todo un pueblo la voz narrativa revela que la mamá de Isabel desciende de indígenas; por lo tanto, la protagonista es mestiza. No obstante, esta palabra nunca se menciona en la obra (ni siquiera para referirse a Julián) y la descripción física de la protagonista no refleja su ascendencia sino el ideal de dama enamorada de clase alta y, por supuesto, blanca.
} 
habitualmente identificaba a los personajes masculinos atractivos. Resulta atípico que dos personajes tan dispares como Julián e Isabel sean pareja y, además, parientes. La única explicación, en términos naturalistas, es que la ascendencia indígena de ambos esclarece por qué son los únicos habitantes honestos de la ciudad. En Todo un pueblo los rasgos morales positivos son asociados al pasado indígena; por lo tanto, y desde el punto de vista narrativo, era necesario que ambos personajes los hubiesen recibido en herencia pues el medio, como ya argumenté, no los propicia.

De manera sorpresiva, Pardo revaloriza a través de Julián y su herencia (y no de Isabel pues su ascendencia indígena se nombra solo una vez) el aporte cultural indígena, tachado de bárbaro, como elemento más puro y necesario para lograr una verdadera modernización. Julián es el único personaje capaz de ver y denunciar las deficiencias de la modernidad y de la sociedad urbana en la que vive. En este sentido, su apellido hace referencia a una especie de hidalguía moral e intelectual y no social. El protagonista concluye que la ciudad está moral, material e intelectualmente enferma y señala en una conferencia magistral delante de sus conciudadanos:

La patria con los gritos estereotipados de «Libertad», de «Orden», de «Progreso», os sirve de pretexto para hacer mangas y capirotes de los gobiernos constituidos; para entrar a saco en la hacienda pública; para blasfemar furiosamente en la calle, para deshonrar los hogares de aquellos que no piensan como nosotros (...) para interrumpir el trabajo de gentes 
honradas y elevar a categoría de inmaculados a unos cuantos pícaros que debían estar en los banquillos, frente a los jueces $(\ldots)(118)^{62}$

La barbarie en Todo un pueblo no está encarnada entonces en el interior del país, como alegaba Domingo Faustino Sarmiento, sino, como dictaminó Rodó en su Ariel, en el utilitarismo (personificado en Anselmo Espinosa y en menor medida en personajes como Las Pérez Linaza) presente en la urbe. La campaña de Julián Hidalgo por modificar los valores citadinos fracasa $\mathrm{y}$, ante las presiones de la vida urbana, el protagonista se autoexilia en su hacienda familiar. No obstante, la derrota no es definitiva. Al enterarse de los amoríos de su suegro con su madre, y después de que el primero lo amenazara con un revolver, Julián mata a Anselmo. En este asesinato se puede leer el triunfo del elemento puro indígena, propio de la nación, sobre la barbarie del inmigrante que se asienta en las ciudades. No es casual que esta escena esté ambientada en el interior del país, lejos del ruido de la modernidad y de Villabrava. La naturaleza, que también fue testigo de la valentía de los antepasados indígenas de Julián, aplaude su proeza. La novela cierra de la siguiente manera:

En tanto el último rayo del crepúsculo, filtrándose por entre el espeso follaje, caía sobre la limpia hoja del cuchillo, sobre el lívido rostro de Espinosa (...) dijérase que rugía de satisfacción el bosque entero (...)

\footnotetext{
${ }^{62}$ Todo un pueblo está narrada en tercera persona con la excepción del capítulo X, en donde aparece la conferencia de Julián Hidalgo, que está escrita en primera persona. En el capítulo anterior aclara el narrador: "Más como no queremos ser cómplices de tan descabellada pretensión, dejamos al audaz conferenciante toda la responsabilidad de sus ideas cediéndole en absoluto la palabra" (110). La estrategia retórica de adjudicar a personajes ideas u opiniones controversiales es de antigua data. El ejemplo más conocido en la literatura hispana se encuentra en El ingenioso hidalgo Don Quijote de la Mancha. Cervantes crea al historiador morisco Cide Hamete Benengeli y a él le adjudica la autoría de la novela completa. Los textos de Cervantes y de Pardo también tienen en común el uso irónico de la palabra "hidalgo" para describir a sus personajes principales quienes no encajan con la figura tradicional de un hijodalgo. Es probable que Miguel Eduardo Pardo haya leído y estudiado la obra de Cervantes; sobre todo si se toma en cuenta sus estadías en España.
} 
estremecimiento de árboles seculares, testigos de horrores no olvidados; y águilas gigantescas que, extendiendo sus alas enormes, cruzaron con poderoso vuelo por las cabeceras del torrente, y fueron a contrale, en su épico idioma de graznidos al abierto espacio, la hazaña de un Hidalgo que acaba de cobrarse en sangre la injuria hecha a su tribu por el representante de aquella sociedad infatuada, que lo había arrojado de su seno. (304-305)

La modernidad europea se intenta imponer a la fuerza y sin miramientos de la misma forma que durante la Colonia se instauró la civilización española. Solo los indígenas resistieron en ambos casos y Julián se venga por él y por sus antepasados. Pardo propone así la necesidad de eliminar elementos extranjerizantes para posibilitar una modernidad en términos nacionales.

La decisión de Pardo de colocar el pasado indígena como elemento regenerador resulta atípica en la literatura venezolana del momento por dos razones. En primer lugar, y tal como indica Yolanda Salas de Lecuna, en aquellos momentos el aporte étnico o cultural indígena desempeñaba, tanto en Venezuela como en el resto de Latinoamérica, un papel irrelevante en la discusión sociológica referida al proceso de conformación de la nacionalidad (60). En segundo lugar, la influencia cultural indígena en Venezuela resultaba, y aún resulta, limitada puesto que, además de la valoración despectiva que se le diera a finales del siglo XIX, la densidad poblacional indígena era y es mucho menor que en otros países latinoamericanos como México o Perú. Para el momento de publicación de Todo un pueblo, el intento más significativo de la literatura venezolana por incluir la diversidad en el acervo nacional venezolano había sido el ya mencionado cuadro de costumbres Un llanero en la capital escrito por Daniel Mendoza en 1849. Si bien Mendoza 
rescata el saber y el habla del llanero, propone la idea de que estos tienen que ser tamizado por la ciudad y la civilización para ser considerados verdaderamente útiles para nación moderna. El origen étnico de los llaneros se remonta a la mezcla de tribus indígenas autóctonas de la zona, como los arahuacos, con andaluces y/o canarios y, en menor medida con negros esclavos. Hay que resaltar, sin embargo, que en el texto de Mendoza el llanero es siempre descrito en términos raciales ambiguos.

Por otro lado, Julián Hidalgo es también descendientes de la antigua clase criolla terrateniente por parte de su madre, Susana Pinto. Una muestra clara del estatus familiar es el hecho de que Julián tenga una hacienda heredada de su familia en el interior del país. Pensemos que parte del paso a la modernidad implicó un cambio en el concepto de riqueza: la antigua aristocracia poesía tierras mientras que la burguesía emergente tenía dinero. De esta manera, y tal como propone Beatriz González Stephan, el triunfo de Julián sobre Anselmo implica también el éxito de los valores del hispanismo colonial enarbolados por la aristocracia criolla por encima de los valores modernos de la burguesía ("Todo un pueblo: Modernismo/modernidad..."258). En Julián Hidalgo están en constante tensión la posición social del personaje (casi siempre asociada a una élite "homogéneamente" blanca) y la categoría racial a la que pertenece (la cual lo convierte de manera automática en un ser subalterno). Esta revalorización simultánea tanto del pasado indígena como del colonial resulta contradictoria mas no atípica dentro de la literatura latinoamericana del momento. Para formar nación, las élites y los intelectuales decimonónicos se enfrentaron al reto de tratar de reconciliar la Europa extranjera pero civilizada que emulaban y las culturas indígenas que, a pesar de considerarse bárbaras, representaban lo autóctono latinoamericano. 
Críticos como Gonzalo Picón Febres afirman que Todo un pueblo es una de las novelas satírico-sociales más sobresalientes del continente (136). Llegados a este punto cabría preguntarse si existe un conflicto entre los parámetros estrictamente cientificistas del naturalismo, expuestos en Todo un pueblo, y la sátira social que emplea Pardo en casi todos sus escritos, incluida su novela. Resulta casi imposible imaginarse el nivel de burla y el tono jocoso que muestra la voz narrativa de Todo un pueblo en una obra de Zola. Además, el naturalismo apuesta por la imparcialidad y la documentación objetiva de la realidad mientras que en la sátira está implícita la valoración del autor del objeto, persona o ambiente del que se mofa. No obstante, desde el punto de vista ideológico ambos géneros, aunque opuestos estéticamente, comparten el deseo de generar conciencia en el lector a través del señalamiento. Si solo se pudiese resaltar una característica de la literatura latinoamericana de fin de siglo, sería la hibridez de géneros. Nuestros autores emularon y copiaron a los europeos, pero no lo hicieron al pie de la letra. De allí la existencia de una obra tan particular como lo es Todo un pueblo que logró unir géneros en apariencia opuestos. El autor naturalista escribe su obra para comprobar una hipótesis y el satírico lo hace para exponer o demoler una certeza tonta (Griffin 52). Con Todo un pueblo Miguel Eduardo Pardo hace ambas cosas. El señalamiento es entonces claro: ni Caracas es ciudad ni Venezuela es un país moderno.

\section{Conclusión: La superficialidad de la modernidad y la ciudad a través de un personaje}

Blanche Housman Gelfant divide las novelas urbanas en tres categorías: "The portrait study, which reveals the city through a single character (...) the synoptic study, a novel without a hero, which reveals the total city immediately as a personality in itself; and 
the ecological study, which focuses upon one small partial unit such as a neighborhood (...) and explores in detail the manner of life identified with this place" (11). En este contexto, tanto el título de La gran aldea como el de Todo un pueblo resultan engañosos pues hacen referencia a una totalidad que no aparece en ninguna de las dos novelas. ${ }^{63}$ El lector podría asumir que en ambas obras se va a conseguir con un synoptic study que abarque la totalidad de la ciudad y/o de la sociedad; no obstante, en las dos novelas nos encontramos con un portrait study.

En el texto de López conocemos Buenos Aires a través del protagonista, Julio Rolaz, quien es además el narrador, y en el de Pardo es la visión de ciudad de Julián Hidalgo la que permea toda la obra. A pesar de lo que podrían indicar los títulos, los espacios urbanos de ambas novelas se circunscriben a aquellos frecuentados por las clases altas (burguesía y aristocracia) bonaerense y caraqueña respectivamente. Esto es una cuestión frecuente en la novela realista y naturalista decimonónica (géneros a los que se circunscriben las dos novelas); sin embargo, en el caso de La gran aldea y Todo un pueblo la decisión de poner la lupa sobre las clases altas responde también a un afán de poner en tela de juicio los comportamientos y valores de aquellos que controlan el poder político, económico y cultural de la nación y que son, por ende, los responsables de conducir al país a la modernidad.

Los protagonistas de ambas novelas nacen y crecen en la ciudad, pero emprenden un viaje que por distintos motivos los aleja de ella. Julio Rolaz sale de Buenos Aires para completar su educación secundaria y Julián Hidalgo sofocado por la urbe se autoexilia en

${ }^{63}$ La segunda edición de la novela de Miguel Eduardo Pardo se publicó en 1902 con el título de Villabrava. 
la hacienda familiar en varias ocasiones. A los pocos años de su partida, los dos personajes regresan a sus respectivas ciudades de origen para encontrarlas significativamente cambiadas. Las renovaciones arquitectónicas, publicitadas por los políticos de turno como manifestación del progreso nacional, esconden alteraciones profundas al estilo de vida tradicional y modificaciones significativas en las relaciones interpersonales de los ciudadanos. Julio Rolaz y Julián Hidalgo luchan entonces por conseguir un lugar en esa nueva ciudad caótica que les resulta familiar y desconocida a la vez. Pese a sus esfuerzos, los dos terminan por despreciar la urbe moderna que consiguen a su regreso a la capital.

Tanto las reformas arquitectónicas como los cambios sociales y las nuevas costumbres y valores produjeron un efecto de extrañamiento en los habitantes de las ciudades que empezaron poco a poco a no reconocer su propio entorno urbano. Anselm Strauss define este fenómeno como disjunction, y lo califica como un estado cualitativo discontinuo entre un periodo de la ciudad y otro (21). Este estado es el que intentan retratar tanto López como Pardo a través del periplo de sus protagonistas. En ambos casos los autores se concentran en la bisagra entre los dos períodos de las capitales: las ciudades poscoloniales que dan paso a las metrópolis modernas. No obstante, la posición que asumen con respecto a esta metamorfosis es siempre crítica. En estas novelas no se ensalzan las capitales como portaestandartes de la civilización, sino que se denuncian sus deficiencias. Tanto Buenos Aires como Caracas son caracterizadas como aldeas con algunos rasgos superficiales de ciudad. Abordar las insuficiencias de la ciudad como espacio civilizado implica la apertura de una línea de cuestionamiento acerca de las supuestas bondades de la modernidad. 
Victor Goldgel señala que la modernidad en Latinoamérica puede ser pensada como "una nueva forma de experiencia histórica en la cual el presente se vive como un período de continua transición y ruptura" (37). A finales del siglo XIX, esa situación de cambio perpetuo produjo entusiasmo y angustia por igual. El paso de Latinoamérica a la modernidad no fue entonces ni tan fluido ni tan celebrado como ha querido hacer ver la historiografía latinoamericana tradicional y tanto La gran aldea como Todo un pueblo son muestra de ello. Las imágenes de las ciudades fueron utilizadas por muchos intelectuales y políticos del momento como portaestandartes del progreso; pero, y quizás irónicamente, ese mismo espacio se convirtió en símbolo de cuestionamiento de la mano de autores como Lucio Vicente López y Miguel Eduardo Pardo. Tanto en Argentina como en Venezuela la novela urbana nace como espacio literario de cuestionamiento y denuncia de los proyectos modernizadores liberales y no como celebración de los mismos. ${ }^{64}$

\footnotetext{
${ }^{64}$ Por supuesto, tal audacia tuvo su precio. Tanto Miguel Eduardo Pardo como su novela fueron ignorados y desprestigiados por la crítica literaria venezolana por muchos años. Por el contrario, La gran aldea sí fue aclamada por los contemporáneos de Lucio Vicente López convirtiéndose en obra clave de la literatura argentina. No obstante, López murió de manera casi novelesca por haberse atrevido a desafiar el nuevo status quo moderno y denunciar, durante su gestión como Interventor Federal de la provincia de Buenos Aires, a Carlos Sarmiento, militar y político argentino bien posicionado, por la venta fraudulenta tierras. Sarmiento retó a López a un duelo a muerte y lo mató con el segundo disparo.
} 


\section{CAPÍTULO III}

La urbe, los ciudadanos y las novelas de (de)formación: el caso de Ídolos rotos de Manuel Díaz Rodríguez y Santa de Federico Gamboa

Los Bildungsromane, o novelas de formación, se centran en el desarrollo físico, moral, psicológico y social de un personaje en su paso de la niñez a la adultez. ${ }^{65}$ Este género literario tiene su origen en Alemania a finales del siglo XVIII; ${ }^{66}$ no obstante, fue en el siglo XIX cuando se popularizó y adquirió variaciones regionales tanto en Europa (Inglaterra y Francia principalmente) como en Latinoamérica. De él surgieron otros subgéneros narrativos como el Erziehungsroman o novela de educación, que se enfoca en la escolarización formal de un individuo, y el Künstlerroman o novela de artista, que describe el desarrollo de un artista y su obra. En el contexto de este estudio me interesa el particular y relevante papel que juega la ciudad tanto en las novelas de formación como en sus variantes.

Bildungsroman es una palabra alemana compuesta formada por los vocablos Roman, que significa novela, y Bildung, que significa crecimiento, educación y/o formación. Este desarrollo del individuo implícito en la palabra Bildung implica a su vez

\footnotetext{
${ }^{65}$ Algunos críticos, como Marianne Hirsh, establecen diferencias entre los términos Bildungsroman y "novela de formación" para distinguir entre un fenómeno presente en la literatura alemana vs. un fenómeno de la literatura europea e incluso occidental (295). A mi modo de ver, las diferencias entre las novelas de formación alemanas y las del resto de Europa y Latinoamérica responden a variedades regionales que el género tomó en cada zona y no a cambios fundamentales en la estructura del género. Lo mismo sucedió con tantos otros géneros literarios de la época como el costumbrismo, el realismo o el naturalismo. Por esta razón, en mi estudio utilizaré ambos términos de manera indiferente.

${ }^{66}$ En líneas generales se considera la segunda novela de Johann Wolfgang Von Goethe, Los años de aprendizaje de Wilhelm Meister (Wilhelm Meiters Lehrjahre en alemán), publicada entre 1795 y 96, como la iniciadora de las novelas de formación (Jeffers 49). Thomas Carlyle la tradujo al inglés en 1824; cuestión que contribuyó a expandir el género primero en Inglaterra y luego en el resto de Europa. El término Bildungsroman fue utilizado por primera vez, para describir el tipo de novelas que nos atañen, por el filólogo alemán Karl Morgersten en 1819; sin embargo, fue el historiador, psicólogo y sociólogo alemán Wilhelm Dilthey quien lo popularizó a inicios del siglo XX.
} 
un proceso de madurez tanto personal como cultural y social. Julia Kushigian señala que Bildung es además un concepto que se originó en la temprana burguesía alemana y que hace referencia al proceso a través del cual se le da forma a un individuo y sus potencialidades innatas a través de la experiencia social hasta llevarlo al umbral de la madurez. Esta madurez no es otra cosa que el acomodo de la persona dentro del orden social establecido (223).

En la mayoría de las novelas de formación, la ciudad juega un papel fundamental como espacio que permite y fomenta este proceso de desarrollo del personaje a través de la experiencia. No es casual que así sea puesto que el auge y desarrollo de las ciudades en Europa está relacionado de manera directa con la aparición de la burguesía. Este tipo de novelas pretendía entonces fomentar los valores, la cultura y la moral burguesa como rasgos sociales necesarios en al ambiente urbano. De allí que muchos Bildungsromane presenten personajes que llegan del interior del país para ser educados (de manera formal o informal) en las ciudades. Estas novelas también hablan de la formación de los ciudadanos ya que se espera que el proceso de aprendizaje lleve a los protagonistas a formar parte útil de la sociedad. Al respecto señala Kushigian: "its goal in the German formula was to inspire the middle class to a life of public service, with obvious benefits for the state" (15).

Por otro lado, Blanche Haousman Gelfant argumenta que los portrait study, un tipo de novela de ciudad en la que la urbe se revela a través de un solo personaje y su experiencia, y los Bildungsromane pertenecen a la misma tradición literaria ya que ambos tipos de novela se ocupan del crecimiento de un personaje hasta llegar a la madurez: 
Structurally, the novel is built upon a series of educating incidents in which the city impresses upon the hero its meaning, values and manners. As the hero responds to the insistent pressures of city life, his character undergoes a change: he learns what the city is, and this is his achievement of sophistication and maturity. (11)

En los portrait studies los cambios psicológicos, morales y/o sociales que sufre el personaje no se derivan de un contacto superficial con el entorno urbano, sino que más bien son producto del estilo de vida específico y la dinámica social y moral que la ciudad imprime en los individuos que la habitan; por lo tanto, el protagonista se ve en la obligación o la necesidad de adaptarse a las expectativas y patrones de conducta urbanos. Este proceso, por supuesto, puede o no ser armonioso. Con el tiempo, El protagonista puede ajustarse de manera satisfactoria a un modo de vida urbano, acomodarse a sus estándares de vida y buscar sus objetivos o, una vez que se da cuenta de las implicaciones sociales y/o personales que este acomodamiento supone, puede repudiarlo (Housman Gelfant 11). Esta posible representación negativa del proceso de formación en los portrait studies empalma con la tradición del Bildungsroman en Francia e Inglaterra que, a diferencia de los textos alemanes, no siempre culminan con el ajuste del individuo en la sociedad. De hecho, en muchas de estas novelas se pone en tela de juicio los valores y dinámicas sociales burguesas al punto de que el acomodo puede significar una especie de capitulación e incluso una traición a las virtudes personales del individuo.

En Latinoamérica, textos como Ídolos rotos (1901), un Künstlerroman del venezolano Manuel Díaz Rodríguez, y Santa (1903), un Bildungsroman del mexicano Federico Gamboa, continúan esta línea de cuestionamiento. En ellos es la ciudad, con todo 
su esplendor moderno, el espacio que no solo impide el desarrollo formativo de los personajes, sino que también desencadena su deformación y, por extensión, su incapacidad de convertirse en ciudadanos útiles para las naciones modernas que se estaban tratando de establecer en Latinoamérica desde mediados del siglo XIX. Los protagonistas de ambos textos, un artista y una prostituta respectivamente, desempeñan además oficios comunes pero conflictivos dentro de la modernidad latinoamericana. En este capítulo estudio cómo esta particular aproximación a las novelas de formación encierra un cuestionamiento de la ciudad como espacio formador y civilizador y, a la vez, un señalamiento a las capacidades de las élites urbanas para construir y dirigir una nación moderna.

\section{1. Ídolos rotos: el Künstlerroman urbano y el fracaso del artista}

En 1901, dos años después de la aparición de Todo un pueblo de Miguel Eduardo Pardo, el venezolano Manuel Díaz Rodríguez publica su primera novela y quizás la segunda novela urbana venezolana: Ídolos rotos. Este texto narra en tercera persona la historia de Alberto Soria, joven descendiente de la antigua clase mantuana, que regresa a su ciudad natal, Caracas, apremiado por la enfermedad del padre, luego de haber vivido cinco años en París. El viaje del protagonista a la capital francesa había sido auspiciado por el viejo Soria que pretendía que Alberto culminara sus estudios de ingeniería en Europa. El joven, sin embargo, termina dedicándose al arte y regresa a Venezuela convertido en un escultor condecorado.

Ídolos rotos entra en la categoría de Künstlerroman ya que en el texto se presenta el periplo básico que Francisco Plata identifica en las novelas de artista: "el aprendizaje creativo de un joven artista, prestando especial atención al desarrollo de los ideales estéticos del protagonista, los desafíos que enfrenta al tratar de alcanzarlos y la búsqueda 
de una auto-realización personal y estética" (145). ${ }^{67}$ La mayoría de los críticos consideran Künstlerroman y novela de artista como términos sinónimos; no obstante, otros, como Roberta Seret, establecen parámetros diferenciadores para ambos conceptos. Seret señala que los Künstlerromane narran el proceso creativo del artista desde su niñez hasta su madurez mientras que las novelas de artista se enfocan en narrar situaciones o experiencias que suceden alrededor de un artista-protagonista ya formado. Seret agrega además que las novelas de artistas son menos personales, psicológicas y confesionales que los Künstlerromane (5). Como se verá a continuación, estas afirmaciones no aplican del todo a Ídolos rotos a pesar de que la novela presenta a un protagonista-artista ya adulto.

Alberto Soria tiene éxito como escultor en París; sin embargo, debe regresar a Caracas de manera intempestiva cuando su carrera apenas comienza. La enfermedad del padre lo obliga a poner en pausa su desarrollo artístico y retornar a la tierra natal en donde intenta darle forma tanto a su obra como a sus ideales estéticos. En pocas palabras, Alberto Soria es un adulto, pero no por ello es un artista formado o consagrado y la estructura de la novela responde al proceso de formación artística del protagonista. Por estas razones, en el análisis de Ídolos rotos procederé a utilizar los términos Künstlerroman y novela de artista de manera indiferente.

Ídolos rotos está dividida en cuatro secciones bien identificadas, las cuales cumplen la función de poner en evidencia los cambios que sufre la relación de Alberto con su obra

\footnotetext{
${ }^{67}$ A pesar de que la novela de artista se escribe en Latinoamérica desde el siglo XIX, el estudio de los Künstlerromane hispanoamericanos es relativamente nuevo. Es apenas en 1983 cuando Rafael Gutiérrez Girardot utiliza por primera vez dicha categoría dentro del análisis de la literatura del continente. En el caso particular de Ídolos rotos, distintos críticos se han aproximado al tópico del artista en la novela; no obstante, la mayoría, salvo Alexandra Álvarez en su estudio "Ídolos rotos de Manuel Díaz Rodríguez: una tropical 'novela de artista"', no ha desarrollado a cabalidad el tema del proceso formativo del protagonista como artista y su subsecuente fracaso.
} 
artística y con Caracas. La novela y la primera parte del texto inician con el regreso del protagonista de París y con ciertas memorias de su vida en la capital francesa. La estadía de Alberto Soria en París responde a los deseos de los padres latinoamericanos de clase alta del momento que mandaban a sus hijos a Europa para que se educaran en la cuna de la civilización. Alberto debía estudiar ingeniería en Francia para convertirse así en un ciudadano útil para su nación. O al menos eso es lo que pretendía don Pancho Soria. Pero París, además de ser la ciudad de la civilización, era la ciudad del arte y los artistas latinoamericanos decimonónicos (y también los del siglo XX) le rendían culto como espacio de consagración artística. Rubén Darío, por ejemplo, afirmaba: “yo soñaba con París desde niño, a punto de que cuando hacía mis oraciones rogaba a Dios que no me dejase morir sin conocer París. París era para mí como un paraíso en donde se respirase la esencia de la felicidad sobre la tierra. Era ciudad del Arte, de la Belleza y de la Gloria" (Autobiografía 69).

Para los latinoamericanos, la capital francesa era una especie de dios bifronte, al estilo de Jano: por un lado, era la ciudad de los avances tecnológicos e intelectuales de la modernidad y, por otro, era la urbe de la vanguardia del arte. Alberto Soria se decanta por la segunda cara de París y cambia la ingeniería por la escultura. Antes de su regreso a la patria culmina y expone un grupo escultórico, bautizado como Fauno Robador de Ninfas (30), que le vale la alabanza tanto en la capital francesa como en su ciudad natal que publica su triunfo en los periódicos locales. Esta primera victoria le vaticinaba a Soria el inicio de una carrera artística exitosa. La vuelta a la patria no estaba, en teoría, reñida con estas aspiraciones ya que el rencuentro con el terruño fomentaría el desarrollo de sus capacidades creadoras en pro de la nación. Después de todo, y como señala la voz narrativa de la novela, 
los llegados a París buscaban "cual más, cual menos, ideas, luz y energías, que más tarde irían á sembrar como simiente de bendición en el suelo de la patria" (26). Soria además se relaciona en París con un pintor cubano, José Magriñat, quien ejerce gran influencia en sus ideales estéticos. De Magriñat se dice: "en él no cabían sino dos ideas, dos pasiones, dos fanatismos: la independencia de su país y la gloria de su arte” (21). Es así como en el ánimo de Alberto comienzan a entrelazarse los conceptos de patria y arte.

En esta primera parte, predomina el contraste significativo entre la Caracas que dejó Alberto y la que encuentra a su regreso. No obstante, el protagonista no observa la ciudad real, sino que la valora a través de la memoria, de los recuerdos. Un tono nostálgico y a veces de sorpresa ante los cambios permea el reencuentro del protagonista con la familia y con la urbe y sus habitantes:

(...) siguió viendo hombres y cosas a través de los recuerdos, con sus ojos de cinco años atrás (...) ya el cambio de aspecto de ciertas cosas le recordaba a su larga ausencia, ya la intacta fisonomía antigua de otras cosas representábale con tanta viveza el pasado, que le parecía no haber vivido jamás ausente de la tierruca (4).

Como se desprende del fragmento anterior, Caracas es la misma de siempre y a la vez no lo es. Soria, al igual que el ya mencionado Julio Rolaz, protagonista de La gran aldea del argentino Lucio Vicente López, se ve en la necesidad de recorrer la ciudad para poder conocerla y reconocerla. Alberto no solo camina por sus calles, sino que sube a El Calvario para "abrazar con la mirada, como en un solo abrazo de luz y de amor, á la ciudad 
entera" (54). No es casual que el lugar elegido sea el parque El Calvario, una de las obras más significativas de la modernidad guzmancista. ${ }^{68}$

En ese entonces, la pequeña montaña donde se construyó el parque era el punto más alto dentro de la ciudad de Caracas y desde su cima se divisaba la ciudad completa. No en vano colocó Antonio Guzmán Blanco una de sus estatuas, bautizada popularmente como El Manganzón, en la parte más elevada de El Calvario. La escultura del autócrata observaba la ciudad desde lo alto en actitud de legislador romano. La intención era clara: Guzmán Blanco todo lo ve; siempre vigila y controla (incluso cuando se encuentra en París). ${ }^{69}$ Sin embargo, tanto los intentos de Guzmán Blanco como los de Alberto Soria por comprender la ciudad entera con una mirada resultaron inútiles. Teóricos como Burton Pike (ix) y Anselm Strauss (8) recalcan la imposibilidad de abarcar la totalidad de la ciudad (tanto física como culturalmente) debido a sus dimensiones y complejidad. De allí que al

\footnotetext{
${ }^{68}$ Inaugurado en el año 1883 con el nombre de paseo Guzmán Blanco, el parque fue construido sobre una colina conocida como El Calvario. Este es el nombre que aún conserva el espacio hoy en día en el imaginario caraqueño; se repite de generación en generación a pesar de los muchos nombres oficiales que ha recibido el parque a lo largo de los años y de los distintos períodos presidenciales.

${ }^{69}$ Guzmanato es el nombre con el que los historiadores venezolanos han bautizado a un período de casi 20 años en el que prevaleció la hegemonía política de Antonio Guzmán Blanco y sus seguidores. Durante este ciclo Guzmán Blanco fue presidente en tres ocasiones: de 1870 a 1877 (periodo conocido como el septenio), de 1879 a 1884 (periodo conocido como el quinquenio) y de 1886 a 1888 (periodo conocido como el bienio). Durante los lapsos en los que se ausentaba de la silla presidencial, Guzmán Blanco dejaba en su lugar a seguidores cercanos a los que había apadrinado políticamente y se retiraba a Francia. No obstante, y a pesar de la distancia, mantenía el control del país a través de sus partidarios los cuales ocupaban todos los escalafones de la política nacional. Por supuesto, estas ausencias en ocasiones le costaron cierta inestabilidad política ya que sus opositores veían en su lejanía física la ocasión perfecta para desafiar su poder. También algunos partidarios, como fue el caso de Francisco Linares Alcántara nombrado presidente entre el Septenio y el Quinquenio, buscaron materializar una distancia política entre ellos y el dictador aprovechando su ausencia. Pese a esto, Guzmán Blanco logró retomar el control del país en cada uno de sus regresos. El Manganzón fue derrumbada luego del primer período presidencial de Guzmán Blanco. Cuando éste regresó al poder en 1879, fue restituida junto con otra estatua de él mismo, conocida como el Saludante, ubicada frente a las puertas del Congreso en el boulevard Guzmán Blanco. En 1889, cuando Guzmán Blanco salió de forma definitiva del poder, el Manganzón fue derribado de nuevo y, además, desmembrado para que no hubiese posibilidad de volverlo a colocar. Este hecho representó el comienzo del otoño del liberalismo amarillo y de la sombra de Guzmán Blanco en el poder.
} 
principio Alberto sea capaz de identificar los edificios más notables para después caracterizar al resto de la ciudad como "dispersos machones" (55).

La incapacidad de Alberto de reconocer los espacios urbanos, así como sus dinámicas sociales, responde tanto a la complejidad de la urbe como al aislamiento del personaje de la realidad venezolana. A primera vista, pareciera que es la ausencia de cinco años lo que explica este desajuste; sin embargo, y a pesar de que esto no deja de ser cierto, esta enajenación que comienza a dibujarse en esta primera parte de la novela representa un rasgo típico de la clase social a la que pertenece Soria y es consecuencia directa del viaje iniciático a París. Al respecto señala Joan Torres-Pou:

El viaje (a París) dejaba de ser un descubrimiento para convertirse en una manera de vivir que terminaba por hacer del viajero un ser entre dos culturas, a caballo entre la realidad hispanoamericana, que en algunos casos podía serle ajena inclusive cuando estaba en América, y la francesa, que estaba presente en su vida incluso en aquellos períodos de la misma que no transcurría en Francia. ("El intelectual" s/p)

Alberto Soria solo es capaz de darle sentido a Caracas a través de términos que son ajenos a la realidad de la ciudad pero que a él le resultan culturalmente familiares debido a su estadía en París. De allí, por ejemplo, que la describa como una ciudad oriental (57). Por lo tanto, la urbe que leemos en la novela no responde a la realidad concreta de la Caracas de fin de siglo (a pesar de que aparezcan espacios específicos de la misma, como la plaza Bolívar y el ya mencionado parque El Calvario) sino a la visión enajenada del protagonista. En este sentido, el deambular de Alberto por las calles no culmina con el autorreconocimiento del nuevo espacio citadino, como en el caso Julio Rolaz en La gran 
aldea, sino que, por el contrario, ahonda cada vez más el desajuste de Alberto con su entorno. Esto repercutirá a su vez en la incapacidad de Soria de concretar sus ideales estéticos y su obra escultórica.

En la segunda parte de la novela, la enajenación de Soria, apenas perfilada en la primera parte del texto, desemboca en un evidente proceso de desadaptación con el ambiente caraqueño. A través de la boca y de las acciones de sus hermanos, Rosa y Pedro, Alberto descubre poco a poco las dinámicas sociales urbanas permeadas en todo momento por la mediocridad, el oportunismo y el desorden, muy a pesar de las ínfulas europeizantes de la clase alta y del ornato parisiense que se le había dado a la ciudad. La voz narrativa de la novela especifica que Alberto desentonaba con el medio y que era incluso considerado una "monstruosidad en los anales de la elegancia caraqueña" (103). La sociedad capitalina además cuestiona el desenvolvimiento y valor como artista de Alberto; cuestión que el protagonista no puede tolerar y mucho menos después de haber sido premiado en París. ${ }^{70}$ En esta segunda parte se introduce también el tema del monumento a Sucre, licencia de construcción que Pedro pretende conseguir para el hermano a través de sus conexiones con el gobierno. Alberto se deja llevar, aunque sin estar convencido de querer recibir el encargo a través de dichos medios.

El asunto de la estatua de Sucre responde a lo que Julio Ramos identifica como los intentos de la modernidad por densificar la memoria de un pasado específico como método resolutorio de las contradicciones que suponía la voluntad de crear nación y un imaginario común y la destrucción implícita de los sistemas y espacios tradicionales que trajo consigo

\footnotetext{
${ }^{70}$ Críticos como Alexandra Álvarez afirman que una de las características más importantes de las novelas de artistas es precisamente la situación conflictiva entre el artista y su sociedad (206).
} 
las remodelaciones edilicias de la modernidad (161). Ese pasado específico que se deseaba resaltar era, por supuesto, la Independencia y sus próceres como representación de la creación de la patria y de aquellos que la hicieron posible. ${ }^{71}$ La elección de Antonio José de Sucre como figura representativa no es casual puesto que, después de Simón Bolívar, es uno de los próceres más relevantes no solo de la independencia venezolana sino de la sudamericana en general. ${ }^{72}$

A primera vista podría parecer que la oportunidad de crear la estatua de Sucre representaría para Alberto Soria la posibilidad de materializar su deseo de hacer patria y civilizar el suelo natal a través de su arte. No obstante, la estatua de Sucre no responde al impulso creativo de Soria sino a la voluntad del político de turno; individuo al cual el

\footnotetext{
${ }^{71}$ La modernidad latinoamericana, llevada de la mano de los autócratas del momento, también buscó mitificar un pasado reciente, que casi siempre hacía referencia al triunfo del dictador de turno en guerras civiles aún frescas en la memoria de los ciudadanos. Por ejemplo, en 1883 Antonio Guzmán Blanco inauguró el parque El Calvario y en 1895 Joaquín Crepo, su más leal seguidor, colocó en él el arco de la Federación en alusión a la Guerra Federal (1859-1863). Esta guerra fue la guerra civil más larga y costosa de la historia de Venezuela. En ella se enfrentaron los conservadores, quienes se rehusaban a modificar el orden social heredado de la Colonia, en especial el sistema electoral, y los liberales, quienes enarbolaron de nuevo los ideales de igualdad, fraternidad y libertad de la revolución francesa que ya habían proclamado en su momento los republicanos durante las guerras de independencia. La discusión sobre el sistema electoral implicaba una discusión sobre la ciudadanía ya que para definir quién podía y no podía votar era necesario primero delimitar quien era considerado ciudadano y quién no. Antonio Guzmán Blanco formó parte de las líneas liberales y, si bien no fue la figura central del conflicto, con el tiempo se convirtió en la mano derecha de Juan Crisóstomo Falcón, el caudillo principal liberal. A partir de 1870, con la primera elección de Guzmán Blanco como presidente, se inició el periodo conocido como Liberalismo Amarillo, período de aproximadamente tres décadas durante el cual dominaron los liberales. Todas las figuras políticas de esta época estuvieron sometidas o en deuda con la hegemonía de Guzmán Blanco en el poder. Erigir un arco del triunfo en honor a la federación equivalía a honrar tanto el triunfo de lo liberal como proyecto de nación (al menos de manera retórica) como la figura de Guzmán Blanco como ente que lo hizo posible. Así se elevaba la fígura del autócrata a la de los próceres de la independencia quedando todos igualados en el imaginario nacional como padres de la patria.
}

${ }^{72}$ Antonio José de Sucre estuvo involucrado en la independencia de Venezuela, Colombia, Ecuador. Perú y Bolivia. Desempeñó los cargos de presidente de Bolivia, Gobernador del Perú, General en Jefe del Ejército de la Gran Colombia, Comandante del Ejército del Sur, entre otros. Sucre fue asesinado de manera premedita el 4 de junio de 1830. Para la fecha, la Gran Colombia se encontraba en proceso de desintegración (a pesar de que la disolución oficial no llegaría hasta el 19 de noviembre de 1831) y Simón Bolívar estaba ya enfermo e incapacitado de hacerle frente a los movimientos separatistas. Sucre compartía con Bolívar, quien lo tenía en gran estima, la visión política de la Gran Colombia por lo cual era el sucesor lógico del Libertador cuestión que aparentemente le costó la vida. 
protagonista ni estima ni respeta. La vacilación de Alberto ante el posible encargo se debe tanto a los medios turbios a través de los cuales lo puede conseguir, así como a un deseo de independencia de sus ideas y de su arte. La ya mencionada crisis del sistema cultural tradicional que acarreó el proceso modernizador también trajo consigo un nuevo fenómeno: llevó a los artistas y escritores a precisar nuevos límites de autoridad.

Durante la primera mitad del siglo XIX la labor del político y del escritor o el artista muchas veces se fundía en la misma persona. Los personajes más icónicos del XIX son ejemplos claro de la afirmación anterior, y me refiero aquí a figuras como Domingo Faustino Sarmiento, Juan Bautista Alberdi, Andrés Bello, entre otros. Escribir y gobernar eran de cierta manera formas análogas de construir y ordenar el país. No obstante, en las postrimerías del siglo, la situación política y social era ya muy distinta y la escritura y el arte se comenzaron a decantar poco a poco por un lugar de enunciación específicamente literario y artístico frente al doble rol que habían cumplido hasta el momento. El torremarfilismo finisecular es quizás una de las expresiones más extremas de esta separación. ${ }^{73}$ Julio Ramos alega que esta problematización en la relación del arte (literatura, pintura, etc.) y el Estado no solo es un efecto de la modernidad, sino que fue a su vez la condición indispensable que hizo posible la autonomización y modernización del arte a finales del siglo XIX (22). La posición de Alberto Soria con respecto a la estatua de Sucre es espejo y producto de este resquebrajamiento. ${ }^{74}$

\footnotetext{
${ }^{73}$ El torremarfilismo es uno de los fenómenos que se dio en el modernismo (entendido como movimiento literario); sin embargo, no fue característica sine qua non del mismo como argumentaron con frecuencia (y aún argumentan) sus detractores.

${ }^{74}$ Esta dinámica entre gobierno y artista tiene ecos de El rey burgués de Rubén Darío publicado en 1888.
} 
En la tercera parte de la novela Alberto comienza un noviazgo con María Almeida y retoma su labor creativa realizando la escultura de una venus criolla. Esta escultura, a diferencia de la de Sucre, es producto de la estética personal del protagonista ya que entrelaza en sus propios términos el arte y lo autóctono de la patria. Sigue presente, sin embargo, la voluntad de insertar la realidad venezolana dentro de los moldes europeos; de ahí que Alberto se decante por un claro referente grecolatino. Una vez más se recalca la incapacidad de Soria de entender el terruño sin elementos culturales europeos. En esta tercera parte Soria experimenta un renacer de su actividad creativa y su desajuste con Caracas parece aminorar; todo aparentemente motivado por la presencia de María Almeida.

La relación intrínseca entre amor, inspiración y creación artística es harto conocida en la literatura occidental, así como también la recurrente asociación de figuras femeninas a la ciudad o suelo patrio. Maite Zubiaurre afirma que el estereotipo de mujer=ciudad se repitió con obstinada frecuencia en la novela realista y modernista latinoamericana de fin de siglo al punto de que se perpetuó en la narrativa vanguardista del siglo siguiente (329). La pareja de un artista debía cumplir el papel tripartito de acompañante fiel, amante y musa (329-330) y dada la sinonimia entre mujer y espacio urbano, también la ciudad debía desempeñar este papel en el ánimo del artista. Alberto espera lo mismo tanto de su novia como de su ciudad. La voz narrativa señala:

Creyéndola capaz (a María/ Caracas) de aquella comprensión clara y absoluta, fuente de la abnegación y de la fidelidad supremas, indispensables en la compañera de un artista; él entonces, la adoraba, no tan sólo como novia o amante, sino como una fuerza más, necesaria a la fuerza creadora 
de su genio, como una armonía más, necesaria a la perfecta armonía de su glorioso mundo de estatuas. (233)

Durante la estadía de Alberto en París tanto la capital francesa como Julieta, su primera novia, se convirtieron en abono que hizo que brotara el "germen dormido" (18) de la creación artística en el genio del protagonista. Soria busca repetir el proceso en suelo patrio con su ciudad natal y su nueva novia; no obstante, tanto Caracas como María Almeida se quedan cortas. Alberto culmina su venus criolla, pero queda insatisfecho con su obra. A pesar de esto, decide exponerla en un café de la ciudad y recibe la indiferencia tanto de su novia como de sus congéneres:

Pronto, mil pequeñeces de la vida real venían como a decirle: te engañas. No de otra suerte le hablaba la actitud asumida por María, después de la exposición de su última obra. A Alberto le chocó su aparente indiferencia y despego. María afectaba ignorar la experiencia de su última obra y cuanto sobre ésta se había hablado ó escrito. Su actitud, á veces forzada, era sin embargo la misma de todos los de la familia Almeida y de su propia hermana Rosa; todos, como obedeciendo á a una consigna visiblemente evitaban hablar de la estatua (...) Y pensaba también si de aquel infinito, de él presentido é ignorado, si de la valla hecha de hipocresía y disimulo no saldría para él, la hembra instintiva, la eterna esclava y dominadora eterna (...) ¿Qué sería de su arte, de su nombre y de su gloria, si él llegaba á caer en las traicioneras garras de la hembra instintiva? $(233-35)^{75}$

\footnotetext{
${ }^{75}$ Ese tipo de mujer a la que teme Alberto Soria no es otra que la femme fatale, imagen harto utilizada tanto en Europa como en Latinoamérica por los pintores y escritores de finales de siglo XIX y principios del XX. La femme fatale suele presentarse como una mujer de sensualidad y sexualidad desbordada que utiliza sus
} 
La muerte del padre, quien nunca terminó de aceptar que el hijo hubiese cambiado

la vida de ingeniero por la de artista, ${ }^{76}$ así como la poca importancia que María Almeida y los caraqueños, que prefieren discutir temas políticos, dan a su obra constituyen el punto de no retorno en el proceso de alienación de Alberto.

En la cuarta y última parte de Ídolos rotos, Alberto Soria se enfrasca en un amorío enfermizo y posesivo con una mujer casada llamada Teresa Farías. Si María Almeida es el reflejo de la Caracas indiferente y superficial; Teresa lo es del "París adulterado pasado por Caracas o esa Caracas en la que París solo haya un espejo distorsionador” (Zubiaurre 333). Tanto la ciudad como Teresa despiertan en el ánimo de Alberto la misma dicotomía de amor odio. A Caracas la describe como "inmunda y bella" (57) mientras que la amante "parecía hecha de atracción y grima. Teresa le inspiraba la repugnancia que inspiran las

encantos para doblegar la voluntad del protagonista y, en algunos casos, destruirlo. A pesar de que María Almeida nunca es descrita en estos términos, Alberto lee en su indiferencia el inicio de la inevitable traición y se ofusca pensando en cómo esta podría dañar su reputación de artista. Irónicamente es Soria el que engaña a María Almeida al enredarse con Teresa Farías, mujer que sí nubla su temperamento artístico. Mientras dura el amorío, Alberto abandona todos sus proyectos e ideales para dedicarse a esculpirla solo a ella. El tema de la femme fatale es repetitivo en la narrativa de Manuel Díaz Rodríguez pues reaparece en su segunda novela, Sangre Patricia, publicada en 1902, tan solo un año después de Ídolos rotos. En este segundo texto, Tulio Arcos se obsesiona con la imagen de su prometida, Belén Montenegro, quien no logra reencontrarse con él pues muere en altamar en el viaje de Caracas a París. En medio de su duelo, y aconsejado por un amigo médico, Tulio se embarca en el viaje de novios que hubiesen hecho juntos por el sur de Francia. La cercanía al mar incrementa los ensueños y las alucinaciones del protagonista a tal punto que él mismo se lanza por la borda del buque que lo llevaba a Caracas para así poder reunirse con ella. En este caso resulta evidente que la "seducción" de Belén (o más bien del fantasma de Belén) es espiritual y no corporal pues el personaje muere al inicio de la novela. Se revela así, de manera más clara, un rasgo que ya se perfilaba en Ídolos rotos: la supuesta seducción y traición de la hembra pérfida es, en líneas generales, una creación de la mente masculina. Y es que en la imagen de la femme fatale convergen todos los miedos del hombre de fin de siglo con respecto a la sexualidad femenina (que consideraban destructora) y su incapacidad de contenerla si no se constreñía a la mujer al ámbito privado. De allí que en ambas novelas se asocié a la mujer con rasgos considerados primitivos (como los instintos en Ídolos rotos) o con la naturaleza (como el mar en Sangre Patricia).

${ }^{76}$ Este tema pesa en la conciencia de Soria hasta el último momento pues, cuando consiguen el cadáver del padre, le parece leer en su rostro un gesto de desaprobación: "No pudo cerrar sino un ojo: los párpados del otro no podían ya obedecer al tacto benigno de los dedos filiales. En los labios, y sobre todo en la fijeza de aquel ojo sin luz, Alberto leyó repentinamente un reproche" (239). 
culebras y al mismo tiempo le atraía, como el vaso colmo atrae al labio sitibundo" (228).

A pesar de esta ambigüedad, Alberto se dedica febrilmente a hacer una escultura de su amante. No obstante, su trabajo, a diferencia del Fauno robador de ninfas que hizo en París, carece de dedicación y método. Tanto el artista como el proceso creativo presentan más bien rasgos enfermizos, propios de la enfermedad de fin de siglo padecida por los artistas de la época y diagnosticada por los alienistas europeos. ${ }^{77}$ La enajenación inicial de Soria deviene así en neurosis que le impide concretar tanto sus ideales estéticos como su obra artística. $^{78}$

Eventualmente, acontece lo inevitable: la estatua de Sucre es encargada a un hombre con menos talento, pero con más amigos que Soria. Estalla también una de las tantas revoluciones -en la que participa Pedro, el hermano de Alberto. La novela culmina con la entrada "triunfal" de la soldadesca a Caracas y con la destrucción de las obras de Alberto albergadas en el Museo de Bellas Artes, convertido en barracas, a manos de esos mismos "defensores de la nación". ${ }^{79}$ La novela concluye de manera pesimista e irreconciliable:

\footnotetext{
${ }^{77}$ Para analizar el tema la enfermedad finisecular del artista a profundidad sería necesario elaborar un estudio aparte; no obstante, y en el marco de este capítulo, es importante destacar que el nerviosismo y la neurosis de Alberto Soria se intensifica precisamente en la ciudad.

${ }^{78}$ Además, tanto el amorío de Alberto y Teresa como la estatua de esta última son descubiertos por María Almeida y por Rosa, la hermana de Soria; cuestión que precipita el término de la relación del protagonista con ambas mujeres.

${ }^{79}$ Aunque Manuel Díaz Rodríguez no señala de manera explícita en que año transcurre la acción de Ídolos rotos, ciertos indicios, como la aparición de la plaza Bolívar y del parque El Calvario, nos permiten situarla a final del siglo XIX, luego de los períodos presidenciales de Antonio Guzmán Blanco. Otra pista significativa es la revolución con la que culmina la novela. Si bien es cierto que es difícil situar la novela en un momento histórico determinado basándose en un fenómeno, como las revoluciones, que sucedieron incontables veces en la historia de Venezuela (Calcaño 303); pudiésemos asumir que la revolución de la que se habla al final de Ídolos rotos es la Revolución Liberal Restauradora que entró triunfante en Caracas el 22 de octubre de 1899 y que llevó a Cipriano Castro, el primer presidente andino, al poder. Castro inició la
} 
Alfonzo tenía razón cuando me dijo que me fuera. Yéndome entonces, cuando él me lo dijo, me hubiera llevado quizás algo intacto, me hubiera llevado quizás casi entero el buen humor de la tierruca. Alfonzo tenía razón, nadie tiene derecho a sacrificar su ideal (...) Yo nunca, nunca realizaré mi ideal, en mi país. Nunca, nunca podré vivir mi ideal en mi patria. ¡Mi patria! ¡Mi país! ¿Acaso es esta mi patria? ¿Acaso es este mi país? (...) el artista calumniado, injuriado, humillado, escribió con la sangre de sus ideales heridos, dentro de su propio corazón, por sobre las ruinas de su hogar y sobre las tumbas de sus amores muertos, una palabra irrevocable y fatídica: Finis Patriae. (349)

Ídolos rotos es entonces un Künstlerroman fracasado puesto que Alberto no es capaz de concretar ni sus ideales estéticos ni su obra escultórica; sin embargo, es importante destacar que esta incapacidad es producto tanto del ambiente urbano como del propio artista. La Caracas con la que se encuentra Alberto a su regreso valora el oportunismo por encima del talento. El ejemplo más claro de este planteamiento es el general Galindo, ministro del fomento, personaje que no aparece en la novela, pero del cual los demás personajes hablan de manera constante:

- ¡Si tú debes conocer a Galindo! ¿No recuerdas la temporada que pasaste en la hacienda de los Madriz? Pues Galindo era entonces el mayordomo de la hacienda.

revolución en Táchira con apenas 60 hombres; sin embargo, y tan solo unos pocos meses, ya se acercaba a la capital del país y comandaba con fama de invencible a más de dos mil hombres. 
- ¿Ese hombre? Pero si era un pobre diablo de campesino sin desbastar, ignorante del todo.

- ¿Era? -replicó Emázabel - no señor: es (...)

Alberto, que de lejos no siguió el modo peculiar de evolución de la democracia en su tierra, no sabía por tanto de los nuevos nombres y personajes alzados por la onda turbia de las vicisitudes políticas (...). (6162)

Encontramos en Ídolos rotos, al igual que en Todo un pueblo de Miguel Eduardo Pardo, una aproximación rodiana al tema de la barbarie: viene del campo, representada en la soldadesca que irrumpe en la urbe una vez culminada la revolución y que profana las obras de arte expuesta en el Museo de Bellas Artes; no obstante, también está encarnada en la ciudad misma que, como se desprende de la cita anterior, antepone el oportunismo al talento y a la moral. Caracas se convierte así en la antagonista de Soria; constituye el obstáculo principal que le impide concretar sus ideales estéticos, mas es, a la vez, el único espacio pseudocivilizado de la nación en donde podría llevarlos a cabo.

Alberto se niega a ser partícipe de la dinámica social caraqueña razón por la cual la estatua de Sucre termina siendo encargada al mejor postor y no al más calificado. El oportunismo es la única manera de actuar y triunfar en un medio como la Caracas decimonónica y Alberto se rehúsa. Para Soria, "la lucha no es amoldarse al medio, sino combatirlo, modificándolo, haciéndolo a nuestras aspiraciones, á nuestras virtudes, á nuestro ideal" (137). Como he argumentado, el protagonista de Ídolos rotos no es capaz de cumplir con su ideal; no se adapta al entorno, pero tampoco lucha. Por esta razón, 
Alexandra Álvarez ve en Alberto Soria la enfermedad de los héroes decadentes: pasividad, impotencia y spleen (315).

Antes de convertirse en escritor, Manuel Díaz Rodríguez se graduó de medicina en la Universidad Central de Venezuela y viajó a Europa para ampliar y profundizar sus conocimientos. No es de extrañar entonces que en Ídolos rotos se perciba una voluntad de diagnosticar la conducta de Alberto Soria. Curiosamente Díaz Rodríguez no asume la postura de Max Nordau, cuya obra es probable que conociese. En su libro más conocido, Degeneración, publicado en 1892, Nordau asevera que los artistas finiseculares padecen de una disposición de "fin de siglo" provocada por la fatiga que el cuerpo humano manifiesta ante un nerviosismo continuo. Dicha disposición o enfermedad tiene dos síntomas básicos: la degeneración y la histeria (15). Si bien Alberto presenta las angustias y cambios de humor que la literatura y la incipiente psiquiatría decimonónica adjudicaban al llamado temperamento de artista, el diagnóstico del protagonista no responde solo a su profesión sino a la clase social a la que pertenece. De esta manera, Manuel Díaz Rodríguez no utiliza la "barbarie" y hostilidad del entorno caraqueño y la condición de artista del protagonista como justificaciones únicas (y quizás previsibles) del fracaso de Alberto Soria. El autor de Ídolos rotos va más allá de la profesión del personaje principal y de su entorno inmediato de la capital venezolana para concentrarse en la cuna de la civilización para el mundo decimonónico latinoamericano: París.

Durante el siglo XIX, el viaje a París se convirtió en leitmotiv tanto en el mundo ficcional de la literatura latinoamericana de fin de siglo como en el ámbito real de las clases altas latinoamericanas de la época. Como muestra, la voz narrativa de Ídolos rotos asegura que el padre de Alberto consideraba el solo hecho de cruzar el océano y llegar a París como 
un éxito en sí mismo (17). El viaje a la capital francesa se conceptualizaba como una especie de iniciación en la civilización. Joan Torres-Pou señala al respecto, que la capital del Sena se convirtió para los latinoamericanos en espacio al que era necesario acudir para descifrar las claves que erradicarían la barbarie de sus respectivas naciones. Por esta razón, este viaje de aprendizaje pasó a ser un factor determinante en la actitud de la intelectualidad latinoamericana ante la problemática de sus respectivos países (“El intelectual” s/p).

Giusseppe Zarone, por su parte, indica que la ciudad mítica es en sí misma una patria (41). La Caracas finisecular era una ciudad mítica, o más bien utópica, en el sentido de que se le apreciaba no como era, sino por cómo podía llegar a ser; es decir, por la posibilidad de llegar a ser moderna y estar a la par de una capital europea. Recordemos que la voz narrativa de la novela insiste en repetidas ocasiones en el hecho de que Alberto ve la ciudad a través de sus ojos, entrenados en París, que solo son capaces de entender referentes culturales europeos. Es por esto que, cuando la realidad anula la utopía de Alberto, el protagonista se queda sin patria. Soria se autoexilia, probablemente en París (aunque la novela no lo especifica); no obstante, y a pesar de los nexos culturales que lo unen a Europa, seguirá siendo un alienado pues tampoco pertenece a la capital francesa.

A comienzos del siglo XX la modernización impulsada por las élites liberales aún dejaba mucho que desear en términos del alcance del tan anhelado progreso. La situación, a ojos de Díaz Rodríguez, no se debía a la barbarie arraigada en Latinoamérica sino también a los supuestos encargados de dominarla, entre los cuales se podría incluir a Alberto Soria como representante tanto de la intelectualidad caraqueña como del gremio artístico. Estos individuos incapaces de reconciliar los parámetros civilizadores europeos con la realidad latinoamericana se quedaban estancados en un "no man's land social" del que eran 
incapaces de salir (Torres-Pou, "El intelectual" s/p). Ídolos rotos cuestiona la capacidad civilizadora de las élites latinoamericanas y señala al europeísmo y afrancesamiento, supuestas claves de la civilización, como los elementos que entorpecieron el proceso de modernización y que evitaron que Venezuela (y Latinoamérica por extensión) alcanzara el progreso con el que se soñó durante la primera mitad del siglo XIX. ${ }^{80}$

A pesar de que Ídolos rotos despertó interés tanto en Latinoamérica como en España muchos contemporáneos de Manuel Díaz Rodríguez criticaron con dureza la otredad sistemática que este asumió en su novela frente al espacio del país (Mata Gil 217). ${ }^{81}$ Sin embargo, esta aproximación no es más que un lugar común de los detractores del modernismo -movimiento al que se ha asociado la figura de Díaz Rodríguez- quienes no estaban de acuerdo con la importancia que los escritores modernistas daban a las cuestiones estéticas en detrimento de otros temas. ${ }^{82}$ Esto, por supuesto, era entendido en la época como

${ }^{80}$ Esta postura de Díaz Rodríguez con respecto a las élites urbanas y su desempeño en el proceso de modernización no es única, sino que era compartida por otros escritores finiseculares; como por ejemplo Eugenio Cambaceres, escritor argentino miembro de la ya mencionada generación del 80 a la que también perteneció Lucio Vicente López, autor de La gran aldea. En 1885 Cambaceres publicó Sin rumbo, texto que narra la vida diletante de Andrés, un joven de la clase alta bonaerense que divide su tiempo entre la capital y la estancia familiar. El título de la novela hace referencia tanto al personaje principal como a la clase social a la que pertenece. Sin rumbo plantea la muy mentada dicotomía entre campo y ciudad; no obstante, le da un giro. En el texto, Buenos Aires se dibuja como espacio degenerador mientras que la estancia se plantea como el único ambiente que podría regenerar a esa clase enferma que, radicada en la artificialidad de la ciudad, no había sido capaz de llevar las riendas de la nación de manera efectiva. Esta conceptualización positiva del campo fue retomada y expandida durante las primeras décadas del siglo XX por los escritores regionalistas, autores de las llamadas novelas de la tierra. Cambaceres, sin embargo, no es tan optimista como algunos escritores posteriores. Si bien es cierto que Andrés cambia su modo de vida una vez que se muda de forma definitiva a la estancia para hacerse cargo de su hija Andrea; el idilio resulta breve pues la niña fallece debido a la difteria y el protagonista se suicida. La muerte de Andrés puede leerse como el fracaso de su clase social y su visión de progreso y modernidad. Desde este punto de vista Cambaceres es tan pesimista como Díaz Rodríguez con su Finis Patriae.

${ }^{81}$ Tanto Miguel de Unamuno como Ramón del Valle Inclán comentaron la novela de Díaz Rodríguez.

${ }^{82}$ Las primeras obras de ficción de Díaz Rodríguez fueron cuentos y se publicaron en dos volúmenes: Confidencias de Psiquis en 1896 y Cuentos de color en 1899. Los cuentos de la primera antología están concebidos como confesiones acerca de diferentes situaciones y sentimientos que produce el amor. Por otro lado, cada narración del segundo compendio lleva por título el nombre de un color el cual es a su vez asociado 
una especie de subversión al orden patriótico que pretendía presentar a Europa la imagen de una Latinoamérica civilizada (de allí que se prefirieran los temas urbanos sobre los rurales). Con frecuencia se ha igualado la figura del autor con la del protagonista de la novela ya que ambos tuvieron una relación antagónica con su entorno; no obstante, Díaz Rodríguez no se conforma con la pasividad y la evasión e Ídolos rotos es muestra de ello. Esta novela, no es un texto evasivo sino una denuncia clara que vaticina el drama de una urbe y una clase dirigente sin arraigo cultural que asume la dirección de una nación entera que se encuentra encaminada a un dudoso progreso.

\section{Santa: ¿Novela de (de)formación o Bildungsroman fracasado?}

En 1903 el escritor mexicano Federico Gamboa publicó la que sería su obra más conocida y quizás el único best-seller mexicano de la época (Schlickers 145): Santa. La novela narra en tercera persona la vida de Santa, una hermosa joven de Chimalistac que se muda a Ciudad de México luego de que sus hermanos y su madre la expulsaran de la casa por haber quedado embarazada de Marcelino Beltrán, un militar de alto rango que la abandonó y se desentendió de ella y del bebé (que Santa posteriormente abortó). La historia de la protagonista en la capital de México se inicia con su llegada a la casa de doña Elvira, un conocido prostíbulo donde inmediatamente comienza a trabajar. Al poco tiempo de su arribo Santa se convierte en la hetaira más cotizada del establecimiento e, incluso, de la ciudad.

Desde el punto de vista estructural, Santa es un Bildungsroman ya que, como propone Juan Armando Epple, la narración se articula a partir del paso biológico de la

a estados del alma específicos. Con sus novelas Díaz Rodríguez se aleja tanto del lenguaje preciosista típico del modernismo, y utilizado en sus cuentos, como de los temas que atañen de manera exclusiva al mundo interior del individuo que, hasta el momento, habían sido el tópico central de sus narraciones. 
protagonista de la adolescencia a la adultez y del tránsito psicológico de la inocencia a la conciencia crítica (34). El nombre del texto es, en este sentido, significativo pues tanto la protagonista como la novela comparten el mismo apelativo. A primera vista pareciera que el proceso de formación de Santa (y me refiero aquí tanto a la novela como al personaje) sigue los patrones de los Bildungsromane tradicionales: un joven poseedor de una sensibilidad particular crece en un pueblo en donde encuentra limitaciones sociales y/o intelectuales; por lo tanto, abandona el hogar para abrirse camino en la ciudad. Ahí comienza su verdadera "educación"; no solo su preparación para una carrera sino también su experiencia directa de la vida urbana (Buckley 17-18). Aunque Federico Gamboa se valió del género alemán, modificó su fórmula desde el inicio ya que esa preparación de carrera, o en este caso de oficio, que recibe Santa la convierten en prostituta. Efectivamente la protagonista experimenta la vida urbana y se acopla a ella, pero en al ambiente más abyecto y, sin embargo, popular de la capital mexicana a comienzos del siglo XX.

La novela de Gamboa está dividida en dos partes que responden al proceso (de)formativo de la protagonista como prostituta y a su relación con la ciudad que primero la aclama y que luego la desprecia. La primera sección inicia con su llegada a la casa de doña Elvira donde Pepa y las demás muchachas la adiestran en las artes de seducción: cómo vestirse, qué tomar, cómo comportarse, qué decir y de qué manera, etc. Santa rápidamente se convierte en la cortesana más codiciada y, a pesar de tener numerosos pretendientes que le ofrecen salidas a ese estilo de vida, Santa no se retira sino hasta el final de esta primera parte, de la mano del Jarameño, uno de sus enamorados. La segunda parte abre con la vida aburguesada de Santa en una pensión junto a su nuevo novio. La protagonista rápidamente se hastía, lo engaña y regresa a casa de doña Elvira, pero ya ni su salud ni su reputación 
son las mismas. Vuelve a salir de la casa de citas cuando Rubio, un hombre casado que también la pretendía, le ofrece mantenerla como su querida. Al poco tiempo Santa huye nuevamente pues Rubio comienza a maltratarla. Resulta irónico que la única vía para que Santa salga del prostíbulo sea de la mano de un hombre que, bajo los parámetros sociales y morales del momento, solo podía hacerla su querida, pero jamás su esposa ni la madre de sus hijos (al menos los legítimos). Incluso con el Jarameño, un hombre soltero, Santa está limitada a ser una barragana. Está implícito que su pasado como prostituta le impide ser una esposa digna y recuperar la posición que le tocaría dentro del orden social establecido. Por otro lado, ser la querida exclusiva de un hombre le suprime la libertad de movimiento y de dinero que le otorgaba su antiguo trabajo. De cierta manera, la condición de amante no es más que una extensión de la vida de prostituta, esta vez controlada por un seudo pater familias al que somete tanto su voluntad como su economía.

A partir de la huida de Santa de la casa de Rubio, se precipita el verdadero descenso de la protagonista, quien sufre de una enfermedad inicialmente no identificada que poco a poco le impide ejercer su oficio. Por esta misma razón comienza a beber de manera indiscriminada. Elvira no la vuelve a recibir en su establecimiento. Los prostíbulos que compiten con este último tampoco le abren las puertas pues sus recurrentes escapadas y los rumores que otras prostitutas han extendidos le han dado fama de empleada de poca confianza. Santa pasa de trabajar en los locales de mayor reputación a ser rechazada incluso en los establecimientos de mala muerte. Así, su valor, como el de cualquier otra mercancía, se devalúa en el mercado de consumo, cuestión que demuestra que incluso en los espacios abyectos de la ciudad finisecular existía una jerarquía interna de compra y venta relacionada con el sistema capitalista. Desahuciada, alcohólica y enferma es recogida por 
Hipólito, el pianista ciego del prostíbulo de doña Elvira, que siempre estuvo enamorado de ella a pesar de no poderla ver. Finalmente, Santa muere, de cáncer en el útero, y con su defunción se cierra tanto la segunda parte del texto como la novela. Resulta significativo que la enfermedad de Santa provenga del órgano que la hubiese convertido en madre y, por lo tanto, en un elemento útil para la sociedad.

La elección de una protagonista mujer, por no decir de una prostituta, para una novela de formación finisecular latinoamericana resulta atípica. Marianne Hirsch señala que los Bildungsromane se enfocan en un personaje central representativo de un contexto social definido (296). Ya que este tipo de novelas era generalmente escrito por burgueses y para burgueses o en el caso de Latinoamérica por individuos de las clases altas o medias para su misma clase social; era de esperar leer la historia de un joven de cierto estatus económico y social que busca hacerse un nombre dentro del nuevo orden social de la modernidad y no leer acerca de una adolescente de provincia que llega a la ciudad para convertirse en prostituta. No obstante, la selección del personaje no es ni incoherente ni aleatoria.

Llegados a este punto cabría preguntarse qué pasaba con aquellas mujeres que, como Santa, eran desterradas del único espacio que la sociedad les asignaba. Las opciones no eran muchas y, en un sinnúmero de ocasiones, la prostitución constituía la única opción viable para sobrevivir. ${ }^{83}$ En este sentido, a pesar de que Santa no es un personaje típico de

\footnotetext{
${ }^{83}$ Ya en 1888 la peruana Mercedes Cabello de Carbonera había publicado Blanca Sol. En este texto se narra la caída en desgracia de una dama descendiente de la antigua clase aristocrática limeña que pasa de ser una de las mujeres más ricas e influyentes de la ciudad a convertirse en prostituta para poder mantener a sus seis hijos luego de la ruina del patrimonio familiar. Con esta novela Cabello de Carbonera critica con dureza tanto a la sociedad materialista limeña como a la escasa educación que recibían las mujeres de la época de quienes solo se esperaba que fueran madres y esposas. Esta situación las dejaba sin herramientas para sobrevivir (a no ser por la prostitución) y en un estado de vulnerabilidad extrema. Santa, por ejemplo, reconoce que llega a la casa de doña Elvira porque no sabe trabajar: "-Vengo, -agregó, - porque ya no quepo en mi casa, porque
} 
las novelas de formación de la época, sí es un personaje representativo de su contexto. Al respecto señala Julia Kushigian: "self-realization, identity and development would look different if you took the female or marginalized experience as the norm" (15). De allí que la educación urbana de Santa comience en un prostíbulo, y no en otro espacio citadino, hasta convertirse en la cortesana más codiciada y luego en la más repudiada. Esta experiencia marginalizada por el discurso oficial de la época era la realidad (de)formadora de muchas mujeres en el México de principios del siglo XX.

Como ya señalé anteriormente, el tema de la formación de los ciudadanos es un tópico inherente a los Bildungsromane, género que adquiere popularidad tanto en Europa como en Latinoamérica en las décadas anteriores y posteriores a la formación de las repúblicas. No obstante, a principios del siglo $\mathrm{XX}$, las mujeres no eran consideradas ciudadanas, si entendemos como tal a toda persona titular de derechos políticos y acreedora de ciertas responsabilidades o a todo individuo considerado por el orden establecido como miembro activo del Estado. Los parámetros de ciudadanía, en líneas generales, correspondían (y aún corresponden) a la esfera pública, un espacio vedado para la mujer decimonónica. A final del siglo XIX, el rígido sistema de valores patriarcales solo admitía dos posibles papeles para la mujer republicana: el de madre y esposa o el de religiosa. Es decir, la mujer estaba limitada en ambos casos al ámbito privado, su presencia pública en la ciudad era muy limitada y su protagonismo y/o influencia política era casi inexistente.

me han echado mi madre y mis hermanos; porque no sé trabajar, y, sobre todo, porque...porque juré que pararía en esto y no lo creyeron" (19). Blanca Sol y Santa demuestran una preocupación común ante la situación de la mujer decimonónica, que era básicamente la misma en todos los países de Latinoamérica. Los diferentes orígenes de las dos protagonistas de las novelas de Cabello de Carbonera y Gamboa ponen de manifiesto que ninguna mujer, sin importar la clase social, estaba exenta de caer en la prostitución si el patrimonio y/o núcleo familiar se resquebrajaba. 
Resulta significativo entonces que algunos de los eufemismos que se usan para evitar la palabra prostituta, como por ejemplo mujer de la calle o mujer pública, hagan referencia a esta realidad. $^{84}$

Dentro del orden social burgués, la familia constituía la piedra angular y la mujer desempeñaba el papel de cuidadora o ángel protector de ese hogar que creaba y criaba nuevos ciudadanos modernos para la patria y/o nuevas madres que reproducirían a su vez más ciudadanos. Es decir, las mujeres eran máquinas de hacer y formar ciudadanos, pero no ciudadanas como tal. Al quedar embarazada fuera del matrimonio Santa rompe este andamiaje social y por ello es expulsada del núcleo familiar. Si bien es cierto que la conceptualización del "ángel del hogar” es de origen burgués y europeo, tal como indica M. Ángeles Cantero, "inspiró a todas las clases sociales (tanto en España como en Latinoamérica), no solo a los estratos populares sino también a los aristocráticos, de modo que aquellas mujeres que no adaptaron su comportamiento a dicho modelo merecieron el rechazo y la crítica moral de los que detentaban el poder" (s/p). Además, al convertirse en prostituta Santa pierde también su condición de mujer, pues esta no se podía entender fuera de los términos del ángel del hogar que ya he articulado: “iNo era una mujer. Nó; era una ...!" (23). En este sentido Santa no habla de la formación de un ciudadano sino de la (de)formación de un no-ciudadano.

La protagonista de Gamboa está consciente de su condición periférica (como mujer y como prostituta) dentro del orden social y político urbano. ${ }^{85}$ Durante las celebraciones

\footnotetext{
${ }^{84}$ Por el contrario, la expresión "hombre público" se utiliza para hacer referencia a un individuo que tiene una presencia significativa o un influjo particular en el ámbito social y/o político.

${ }^{85}$ De hecho, en el personaje de Santa se resumen casi todas las características de la periferia urbana de la Ciudad de México a principios del siglo XX: es mujer, pública además, de provincia y mestiza. Uno de los
} 
del 15 de septiembre, fecha en la que se conmemora el Grito de Dolores y el inicio de la independencia mexicana, mientras paseaban por la plaza de Armas (actual plaza de la Constitución), popularmente conocida como el Zócalo, ${ }^{86}$ Santa le revela al Jarameño, un torero español y uno de sus muchos pretendientes:

-Usted nos dijo que era su patria una ventana con geranios y claveles ¿verdad?... Pues usted es más feliz que yo, que hallándome en la mía ni siquiera mía debo llamarla! ...Mi patria, hoy por hoy, es la casa de Elvira, mañana será otra ¿quién sabe?... Y yo...seré siempre una...

Y la palabra horrenda, el estigma, la deletreó en la ventanilla de la calandria, hacia afuera, como si escupiese algo que le hiciera daño. (115)

Colocar esta escena en medio de las festividades conmemorativas de la empresa independentista resulta significativo. Como ya mencioné, durante la modernidad se hizo

pocos rasgos concretos que se especifican del físico de Santa es que tiene el pelo largo y negro (173) y la piel trigueña (226 y 254).

${ }^{86}$ En la madrugada entre el 15 y 16 de septiembre de 1810 el cura Miguel Hidalgo y Costilla, junto a Ignacio Allende y Juan Aldama, llamó a los habitantes del pueblo de Dolores (Guanajuato) a que se levantaran en armas contra las autoridades del virreinato de Nueva España. Para reunir y arengar a los pobladores Hidalgo y Costilla hizo sonar las campanas de la parroquia de Dolores. A este evento se le conoce como el Grito de Dolores y se le considera el inicio formal del proceso de independencia de México. Esta fecha se conmemora desde 1812; no obstante, fue Porfirio Díaz quien mudó la celebración de manera definitiva a la capital del país. En 1896, Díaz mandó a trasladar el esquilón de San José, mejor conocido como la campana de Dolores, la misma que Hidalgo y Costilla hizo sonar, de la parroquia del pueblo a la capital y la hizo instalar en el Palacio Nacional, sede (en aquel entonces) de los poderes ejecutivo, legislativo y judicial. Desde ese momento, cada 15 de septiembre el presidente de México toca la campana ante la multitud reunida en El Zócalo, para conmemorar aquel llamado inicial y el primer paso hacia la independencia. No es de extrañar la estrategia de Díaz quien, al igual que Antonio Guzmán Blanco en Venezuela, buscó igualar y entrelazar sus glorias y su figura a las de los próceres de antaño. La voz narrativa de Santa dice del momento festivo:

Todo á un tiempo, se enciende el balcón histórico, el de barandal de bronce, y dentro de un óvalo de rayos eléctricos, surge el presidente de la república, símbolo en medio á tanta claridad, sin otras divisas que la banda tricolor que le cruza el pecho y lo convierte en el ungido del pueblo. Con noble gesto, coge la cuerda pendiente de la esquila parroquial que atesora el palacio, la hace sonar una vez, dos veces, tres veces, y ella suena, maravillosamente, como ha de haber sonado, allá, en Dolores, cuando despertó á los que nos dieron vida en cambio de su muerte (113). 
uso de la imagen de la gesta emancipadora y sus próceres como símbolo de un pasado heroico y común que pretendía unir a las heterogéneas poblaciones latinoamericanas y dar a entender el progreso de las antiguas colonias con respecto a la vieja metrópolis. Monica Quijada afirma que estas fiestas "se ofrecían como un ámbito simbólico en el que las élites y el pueblo llano unificaban las lealtades, aunándose al culto común de la patria” (pág. 302). A mi modo de ver la denuncia en Santa es clara: la supuesta inclusión vaticinada durante la Independencia y el nacimiento de las repúblicas jamás se concretó. Por esta razón Santa no puede celebrar el Grito de Dolores, pues no es ciudadana, sino llorar su falta de pertenencia. Como se desprende de la cita anterior el único espacio de pertenencia de las prostitutas era el burdel.

Los prostíbulos fueron espacios conflictivos tanto en la ciudad como en la literatura decimonónica. Al respecto, Christiane Schönfld señala: "within bourgeois space, prostitution was visible but not to be seen; observed but to be ignored; desired but to be repudiated" (11). Si bien es cierto que la prostitución es casi tan antigua como la humanidad misma; a principios del siglo XX alcanzó niveles nunca antes vistos en Latinoamérica. Por ejemplo, para 1907, tan solo cinco años después de la publicación de Santa, Ciudad de México ya tenía registradas el doble de prostitutas que París, a pesar de que la capital francesa era cinco veces más grande que la mexicana (Leys Stepan 110). Como se desprende de estas cifras, los burdeles pasaron a ser espacios tan representativos de la modernidad como los paseos y los bulevares. De hecho, en Santa, la casa de doña Elvira no está oculta en la ciudad sino ubicada en un barrio común, de gente de clase obrera, rodeada de todo tipo de comercios e instituciones: cobrerías italianas, una tintorería francesa, una carbonería, una fonda, un taller de monumentos sepulcrales, una moderna 
carnicería, un jardín público con una fuente donde recogen agua los aguadores, una iglesia e incluso una escuela municipal para niños. La voz narrativa dice de la zona: "sobre que el barrio, con ser barrio galante y muy poco tolerable por las noches, de día trabaja, y duro. Ganándose el sustento con igual decoro que cualquier otro de la ciudad" (11). De este extracto se desprende que esta mezcla de negocios diurnos y nocturnos no se limitaba al área específica donde estaba situado el local de doña Elvira; sino que, muy por el contrario, se repetía innumerables veces a lo largo de la capital mexicana.

El orden moral patriarcal de la modernidad burguesa latinoamericana execraba a los prostíbulos; pero, al mismo tiempo, los deseaba como espacios de iniciación en la vida sexual para los jóvenes de alta sociedad, así como ambiente de recreación para los hombres de ese mismo estatus social. La voz narrativa de Santa indica lo siguiente acerca de los clientes del burdel: "los jóvenes que aún no tienen ciertos pudores ó los hombres maduros que ya no tienen pudores ningunos" (256). En este sentido, las casas de citas de cierto estatus, y la de doña Elvira en particular, funcionaban, tanto a nivel narrativo como espacial, como bisagras entre la ciudad habitada por las clases altas y la urbe de las clases bajas. No es de extrañar entonces que, a pesar de ser un espacio sancionado por la moral, no se haya intentado eliminar los burdeles sino regularlos y organizarlos a través de iniciativas como los registros de mujeres públicas, al cual la propia Santa se debe someter a su llegada a Ciudad de México.

El supuesto objetivo de este tipo de proyectos fue establecer un estándar higiénico en la profesión para así evitar el contagio de infecciones de transmisión sexual. ${ }^{87}$ Las

\footnotetext{
${ }^{87}$ El primer Registro de mujeres públicas de Ciudad de México, que contenía 598 fichas, se realizó en 1865 bajo el mandato de Maximiliano de Habsburgo. Después de este primer registro y hasta casi mediados del siglo XX hubo múltiples iniciativas similares. Durante los períodos presidenciales de Porfirio Díaz también
} 
prostitutas debían someterse a revisiones médicas periódicas que quedaban registradas en una libreta que debían tener consigo en todo momento como garantía de buena salud. Al final de la primera parte de la novela de Gamboa, Santa es puesta en prisión por no tener la libreta al día. Desde el punto de vista médico este plan estaba destinado a fracasar puesto que, a pesar de que todas las trabajadoras se sometiesen a los chequeos pautados, los clientes estaban exentos de ellos. Se partía de la premisa de que la prostituta, como individuo social no deseado y representante de lo abyecto, era siempre la fuente del contagio a pesar de que este no fuera siempre el caso. La voz narrativa de la novela de Gamboa señala lo siguiente acerca de los encargados de hacer cumplir el registro de las revisiones médicas:

Son los agentes de sanidad el último peldaño de la pringosa escala administrativa. Estriban sus atribuciones principales en perseguir la prostitución subrepticia y vigilar que las sacerdotisas de la prostitución reglamentada municipalmente, cumplan con una porción de capítulos, diz que encaminados á salvaguardar la salud de los masculinos de la comuna.

\footnotetext{
se crearon registros en otras entidades, además de Ciudad de México, como por ejemplo Puebla, Oaxaca, Zacatecas, Michoacán, entre otras. Se estima que a finales del siglo XIX y principios del XX había alrededor de seis registros distintos de prostitutas en México. No obstante, y a pesar de estos esfuerzos, la prostitución siguió siendo un área fuera del control del Estado moderno debido a que la mayoría de las prostitutas continuaron trabajando fuera de estos parámetros legales. De hecho, el médico y periodista Luis Lara y Pardo publica en 1908 su libro La prostitución en México: Estudios de higiene social en donde analiza el estado de la cuestión y propone nuevas regulaciones, así como también vulgarizar conocimientos útiles para que el ciudadano común se defendiese de la invasión de enfermedades. El prefacio señala lo siguiente: "Si tú, lector, sólo buscas un libro que espolee tu temperamento, cierra éste desde la primera página, porque, probablemente, dejará tu médula tan tranquila como antes y, lejos de hacerte soñar voluptuosidades bizarras, te haría pensar seriamente en algo sano, en algo normal, en la defensa de tu propia vida y de la especie animal á la que perteneces" (VII).
} 
Y como á la vez disfrutan de cierto carácter de policías, es de admirar, en lo general, el sinnúmero de arbitrariedades que ejecutan (...) (179)

Como se desprende de esta cita, en Santa se pone en tela de juicio las intenciones higiénicas de los registros de mujeres públicas. Más que controlar el traspaso de enfermedades, estas iniciativas constituyeron nuevas estrategias de control del cuerpo femenino y la novela de cierta manera lo denuncia. Circunscribir a las prostitutas a los burdeles y limitar su libertad de movimiento por la ciudad suponía una voluntad de limitar a esas mujeres públicas a un espacio relativamente privado.

Por otro lado, los registros de prostitutas se presentaban también como una especie de catálogo para los clientes. En él, y acompañado por una foto de la mujer en cuestión, se colocaba la información personal de cada una: nombre, edad, raza, origen, burdel en el que laboraba, otras profesiones desempeñadas, etc. También se clasificaban las trabajadoras en tres categorías distintas (dependiendo de su reputación y la del establecimiento donde desempeñaban su oficio). Esta división determinaba a su vez el monto que cada una podía cobrar por sus servicios, así como la contribución que debían pagar al Estado para poder laborar fuera de la clandestinidad. De esta manera, tanto los dueños de las casas de cita como el Estado moderno desempeñaban el papel de proxenetas de las mujeres públicas.

En el caso particular de Santa el prostíbulo adquiere una nueva dimensión como espacio educativo y de iniciación en la vida urbana de la joven que en teoría debe ser pura y casta. Irónicamente, en la novela los espacios modernos socialmente aceptados y celebrados, como el hospital, el tribunal y la cárcel, son dibujados como entes de abuso y corrupción que maltratan de manera constante a la protagonista mientras que la casa de doña Elvira constituye un espacio de educación para sobrevivir a dichos atropellos. De 
hecho, la caída en desgracia de Santa no comienza sino cuando sale de la casa de doña Elvira al final de la primera parte de la novela. En este sentido, el prostíbulo funciona en la novela de Gamboa como una heterotopía, concepto (entre la utopía y la distopía) acuñado y utilizado por Michel Foucault para describir espacios de alteridad que funcionan fuera de las normativas y moral hegemónica (“Of other Spaces” 24-27). ${ }^{88}$ Si bien Santa puede entenderse como un Bildungsroman fracasado, si se toma como parámetro la ya citada imagen de ángel del hogar, también puede leerse, al menos la primera parte del texto, como un exitoso proceso de educación y formación de una prostituta; siempre y cuando se entienda por éxito el triunfo monetario y de lujos estipulado por el nuevo orden capitalista. Guadalupe Pérez-Anzaldo propone que, desde un punto de vista ideológico, la figura de la prostituta constituye la antítesis del anhelado progreso ya que su cuerpo es visto como el portador de posibles enfermedades y el distribuidor indiscutible del mal moral (s/p). De allí que en la novela las damas de alta sociedad se escandalicen ante la presencia de Santa en los mismos teatros y paseos que ellas frecuentan. Dicha reacción responde tanto al miedo al contagio de los males asociados a la figura de la prostituta como a la indignación de que esta utilice los espacios modernos reservados de manera tácita a la élite urbana. ${ }^{89}$ También se puede leer en esta indignación un temor implícito de las mujeres

\footnotetext{
${ }^{88}$ Jessica shade Venegas en su estudio "Heterotopic Space and the Limits of Naturalist Discourse in Federico Gamboa's Santa" realiza un análisis exhaustivo del prostíbulo en Santa como una hetrotopía que encierra la condenación social y, a la vez, la salvación espiritual.

${ }^{89}$ Hay que tomar en cuenta que muchas de las renovaciones arquitectónicas de la modernidad latinoamericana transformaron espacios frecuentados por personas de todas las clases sociales, como los mercados, en espacios de uso exclusivo de la élite citadina. Por ejemplo, la plaza Bolívar en Caracas, como ya expuse en el capítulo I con el cuadro de costumbres escrito por Nicanor Bolet Peraza, albergó durante la Colonia y los primeros años republicanos el mercado de la capital. Una vez que se mudó el mercado y que se colocó la estatua ecuestre de Bolívar, Guzmán Blanco, el presidente del momento, estipuló una serie de leyes que prohibían atravesar la plaza sin la indumentaria adecuada. El atuendo exigido, por supuesto, solo podía ser costeado por las clases altas caraqueñas. Así, un espacio público se transformó en una especie de ámbito semiprivado para la élite. El propio narrador de Ídolos rotos de Manuel Díaz Rodríguez señala que la plaza
} 
de alta sociedad a ser confundidas con las prostitutas ya que si éstas se visten y peinan igual que ellas y frecuentan los mismos lugares (y a los mismos hombres) ¿qué diferencia a las mujeres decentes de las públicas? Al respecto señala Julia Kristeva: "It is not lack of cleanliness of health that causes abjection but what disturbs identity, system, order. What does not respect borders, positions, rules" (4).

Santa es entonces un sujeto marginalizado, pero también transgresor ya que en su calidad de prostituta puede hacer lo que a las "señoritas decentes" se les prohíbe: recorrer las calles y disfrutar de los espacios públicos. Al respecto, Manuel López Gallego asevera que los protagonistas de las novelas de formación de la época solían ser hombres ya que para el momento la mujer no poseía la libertad de movimiento necesaria que permite al personaje vivir experiencias decisivas y necesarias para completar el proceso de autorreconocimiento (63). Esta postura es discutible; ya que sí se escribieron algunos Bildungsromane con protagonistas mujeres donde el proceso de formación se desarrolla en un ámbito predominantemente privado. Por ejemplo, Little Women de la estadounidense Louise May Alcott publicada en 1868.

Así pues, el desarrollo formativo de un protagonista sí que se puede presentar en un ámbito privado. Pese a esto, en Santa resulta conveniente que la protagonista sea una mujer pública pues, de lo contrario, se hubiese perdido su visión de ciudad al limitarla al

Bolívar "ofrecía un aspecto de salón, difícil de hallarse en otra plaza pública" (174). Por otro lado, tanto las prostitutas como las "señoritas decentes" se exponían en los bulevares con la misma intención: ganar la atención de los hombres. Las primeras pretendían conseguir clientes de alta alcurnia mientras que las segundas aspiraban a conquistar a los mismos individuos como futuros maridos. Leigh Merecer señala al respecto: "strolling on urban boulevards blurs with the suggestion of lascivious streetwalking" (16) Tal situación supone un cuestionamiento tácito tanto de la moral burguesa como de la institución del matrimonio como su piedra angular. 
hogar. ${ }^{90}$ Desde el punto de vista narrativo las caminatas de la protagonista son necesarias puesto que Santa no es de la capital y tan solo puede conocerla al recorrerla. Como lectores conocemos la cartografía de la ciudad precisamente gracias a los paseos de Santa. Críticos como Deborah Parsons aseveran que la prostituta es una figura opuesta al flâneaur ya que la primera, al igual que la ciudad, es objeto de consumo: "they are regarded as objects of the gaze and their own perspective of looking is not considered" (37). No obstante, en la novela de Gamboa Santa cumple el doble papel de ser observadora y a la vez objeto de observación. De esta manera se revela una perspectiva femenina y marginalizada de la ciudad y de la experiencia urbana en un mundo patriarcal.

Santa ha sido con frecuencia denominada como la Nana mexicana (Schlickers 145), ${ }^{91} \mathrm{y}$ es que el texto es una novela de (de)formación que exhibe rasgos naturalistas. De hecho, el propio Gamboa se consideraba un escritor naturalista. Sin embargo, el autor mexicano también modifica la fórmula propuesta por Zola. En primer lugar, Gamboa no ahonda en uno de los elementos básicos del naturalismo: el determinismo biológico de la protagonista. En algún punto de la novela la voz narrativa hace referencia a la herencia de Santa: "es de presumir que en la sangre llevara gérmenes de muy vieja lascivia de algún tatarabuelo que en ella resucitaba con vicios y todo. Rápida fue su aclimatación, con lo que

${ }^{90}$ Susan Buck-Morrs alega que, en el siglo XIX, la prostitución presentaba la única vía posible para la existencia de la flaneuse, la versión femenina de la flanerie: "el flâneur era simplemente el nombre de un hombre que paseaba; pero todas las mujeres que paseaban se arriesgaban a ser consideradas prostitutas (119). Dorde Cuvardic Díaz estudia a profundidad el tema de la aparición de la flaneuse (si es que la hubo) en el contexto latinoamericano en su artículo "La flaneuse en la historia de la cultura occidental".

${ }^{91}$ Nana fue publicada por Émile Zola en París en 1880. Esta novela forma parte de Les Rougon-Macquart, un conjunto de 20 novelas escritas entre 1871 y 1893 en las cuales Zola pretendía describir y estudiar los defectos producidos por la herencia genética en una familia (cinco generaciones en total) así como la sociedad del Segundo Imperio y sus transformaciones. 
a claras se prueba que la chica no era nacida para lo honrado y derecho" (94). ${ }^{92}$ Pese a esto, el tema no se desarrolla y tanto el autor como el narrador la excusan llamándola "pobre pecadora".

En el prólogo, que curiosamente no funciona como un paratexto sino como parte de la novela misma ya que está escrito por la propia Santa, la protagonista señala: “te confesaré mi historia. Y ya verás cómo, aunque te convenzas de que fui culpable, de sólo oírla llorarás conmigo. Ya verás cómo me perdonas ¡oh estoy segura lo mismo de que lo estoy de que me ha perdonado Dios!" (VIII). La narración entonces no es tan solo un relato diagnosticador de un mal social y moral, sino que también es una confesión, una explicación de las razones del mal proceder de la protagonista para obtener a través de él el perdón de los lectores y, luego, la absolución. Así, la novela de Gamboa pierde la objetividad cientificista que caracteriza a las obras de Zola.

Al final de Santa Hipólito, el pianista ciego y eterno enamorado de la protagonista, concluye: "¡ella una prostituta, él un depravado y un miserable (...) los dos habían vivido en todos los lodos y en todas las negruras, fuera del deber y de la moral (...) sólo les quedaba Dios, ¡Dios queda siempre! (...) ¡á Dios se asciende por el amor o por el sufrimiento!” (393). Los padecimientos por los que tendrá que pasar Santa en su camino a Dios están prefigurados desde su propio nombre. Tal como propone Joan Torres-Pou, en español se utiliza la expresión “es un/a santo/a" para referirse a alguien que aguanta con abnegación las crueldades de la vida (“La ficción” 304). En este contexto las palabras santo

\footnotetext{
92 Al respecto Joan Torres-Pou señala que la herencia de procedencia determinada es un rasgo que constantemente contrapone la manera en la que se presenta el determinismo en las novelas francesas y en las hispanoamericanas. En las primeras se habla de individuos concretos, abuelos, padres, ancestros transmisores de las taras mientras que en las segundas se suele hablar de raza, sangre, tiempos remotos ("La ficción" 308).
} 
y mártir son sinónimas y las injusticias que padece Santa tendrán el potencial de redimirla.

Al respecto Silvia Ruiz-Tresgallo señala que la novela de Gamboa subvierte el discurso de géneros religiosos como la vida de santos. En este contexto el deterioro físico de Santa constituye su martirio y cumple la función de lavar sus pecados e impurezas a través del dolor y el tormento (s/p). Gamboa pasa entonces el naturalismo francés por el tamiz del catolicismo. Bajo los parámetros morales finiseculares Santa no merecía perdón; pero bajo las creencias católicas sí; así, tanto el autor como los lectores (católicos todos) tienen permiso de sentir compasión por la (anti)heroína sin ser juzgados por ello.

Resulta evidente que para la época el prospecto de leer la historia de una prostituta podía exacerbar la imaginación de cierto tipo de lectores que podían recurrir al libro en búsqueda de escenas carnales. Gamboa se excusa y se aleja de estas intenciones al agregar de manera estratégica al final del prólogo, supuestamente escrito por la misma Santa, una sección del prefacio de la La fille Élisa del escritor francés Edmond de Goncourt publicada en 1877:

De mi parte debo repetir, - no para ti, sino para el público, ${ }^{93}$-lo que el maestro de Auteuil declaró cuando la publicación de su "Fille Elisa":

\footnotetext{
${ }^{93}$ Esta persona a la que se refiere Gamboa es el reconocido escultor Jesús F. Contreras a quien le dedica la novela y quien muere un año antes de la publicación de Santa. Contreras fue uno de los escultores más representativos del porfiriato. Entre otras cosas, se encargó del trabajo de fundición (aunque no del diseño) de la conocida estatua de Cuauhtémoc, el último emperador azteca, inaugurada en 1887 y localizada en el cruce de la avenida de los Insurgentes y el paseo de la Reforma en Ciudad de México. Esta estatua es muestra del indigenismo promovido por Porfirio Díaz como parte de las medidas (más retóricas que reales) de inclusión de la heterogeneidad en el acervo nacional moderno. Contreras también fue el autor de 20 de las esculturas de bronce de héroes de la guerra de Reforma (1858-1861) que Díaz mandó a colocar a lo largo del paseo de la Reforma. Porfirio Díaz además llegó a ser accionista de la Fundición Artística Mexicana, el taller establecido por Conteras en la capital de México. Sin embargo, la obra más conocida del escultor no tiene nada que ver con los encargos gubernamentales. Lleva el título de Malgré Tout y representa a una mujer tirada, desnuda, encadenada y aprisionada con grilletes quien, a pesar de todo (como el título de la obra bien indica) tiene la cara levantada en un gesto de anhelo. Esta obra le valió a Contreras el Gran Premio de Escultura y la Cruz de la Legión de Honor de la República Francesa durante la Exposición Mundial de París de 1900. La obra podría leerse como la representación del sentimiento universal de desasosiego que ocasiona
} 
“Ce libre, j'ai la conscience de l'avoir fait austére et chaste, sans que jamais la page echappée à la nature délicate et brulante de mon sujet, aporte autre chose à l'espirit de mon lecteur qu'une méditation trsite” F.G. (VIII) Elisa, la protagonista de la novela de Goncourt, es, al igual que Santa y Nana, una prostituta. No obstante, el tópico de naturaleza delicada al que se refiere el escritor francés en el párrafo anterior no es la prostitución; muy por el contrario, esta es tan solo el alegato que le permite abordar el tema que en realidad le interesa: "la prostitution et la prostituée, ce n'est qu'un épisode, la prison et la prisonnière: voilà l'intérêt de mon livre. Ici, je ne me cache pas d'avoir, au moyen du plaidoyer permis du roman, tenté de toucher, deremuer, dedonner à réfléchir" (VIII). ${ }^{94}$

la libertad coartada. No obstante, y ya que Gamboa dedica Santa al autor de esta estatua, resulta inevitable trazar paralelismos entre la imagen de la mujer de Malgré Tout y la protagonista de la novela, quien también se siente aprisionada y víctima de injusticias. Ambas figuras también pueden entenderse como alegorías de Ciudad de México e incluso de la nación mexicana, asociadas y/o representadas con harta frecuencia por cuerpos femeninos. Santa además se dirige de manera directa a Contreras en el prólogo de la novela, le indica que de barro es y era y que se cuela en su taller con la esperanza de que él registre su corazón (VII). La referencia al barro es dual pues alude tanto al precepto católico presente en el Génesis - "de barro/polvo eres y en barro/polvo te convertirás"- que recuerda a los creyentes la naturaleza efímera de la vida terrenal, como a la materia prima que utiliza el escultor para moldear sus figuras. Asimismo, resulta relevante destacar que la comunicación entre artista (Contreras) y obra (Santa) se hace posible porque ambos están muertos.

${ }^{94}$ Resultan significativos los diferentes títulos con los que se tradujo al español esta novela de Goncourt. A ojos de Flavia Aragón, el uso de la palabra fille remite a un código moral y social muy marcado que puede hacer referencia de manera simultánea al estado civil y nivel social de la protagonista, así como a las relaciones madre-hija (312). La traducción al español más utilizada de dicha palabra (al menos de la forma en que está utilizada en el título de la novela de Goncourt) es: joven. No obstante, este vocablo hispano carece de la riqueza semántica que Aragón le adjudica al francés. Por un lado, no alude ni al estatus civil ni al social sino a la juventud o corta edad de la persona de la que se habla (acepción que también tiene en francés); por otro, forma parte de una reducida lista de palabras que en español carecen de género si no se le coloca al lado de un artículo u adjetivo. Se habla del joven o de la joven. Con la palabra fille no hay duda de que se está hablando de una mujer. Precisamente joven fue la palabra que se utilizó en la primera traducción de la novela, La joven Elisa, que vio la luz en España en 1878, un año después de la publicación en francés. En las siguientes traducciones que datan de inicios del siglo XX la palabra joven fue remplazada por prostituta o por su sinónimo más despectivo, ramera. Si bien es cierto que el título La joven Elisa carece de todas las posibles connotaciones del original en francés; La prostituta Elisa o La ramera Elisa cambia de manera radical la intención de autor quien especificó en el prólogo del texto que la prostitución no era más que un episodio circunstancial de su narración. Inclusive esa primera traducción que usa la palabra joven se toma la libertad de agregar un subtítulo que no existe en el original: Escenas y consecuencias de la prostitución. A mi modo de ver estos cambios e inclusiones revelan tanto la posición social/moral de los traductores como 
La fille Élisa es la denuncia de Goncourt a la implementación en las cárceles francesas del sistema Auburn (de origen estadounidense) el cual, a su modo de ver, conducía a los individuos a la inutilidad y/o locura. Este método penal mantenía a los presos en confinamiento solitario durante la noche y los colocaba en grupos pequeños de trabajo durante el día. Sin embargo, se exigía en todo momento un silencio forzado y absoluto. A los reclusos se les prohibía emitir cualquier tipo de sonido: hablar, cantar, silbar, etc. El silencio continuo pretendía quebrantar the sense of self o sentido de identidad de cada individuo para así obtener su obediencia absoluta. Al utilizar el prefacio de La fille Élisa, Gamboa justifica la elección del oficio de su protagonista y, a la vez, se une a la línea de pensamiento y denuncia de Goncourt.

Santa especifica en su parte del prólogo: "en la inspección de sanidad fui un número; en el prostíbulo, un trasto de alquiler; en la calle, un animal rabioso que cualquiera perseguía, y, en todas partes, una desgraciada. Cuando reí, me riñeron; cuando lloré, no creyeron mis lágrimas (...) cuando cansada de padecer, me rebelé, me encarcelaron” (VII). En pocas palabras, la protagonista de Gamboa fue silenciada y tratada como un objeto de forma sistemática, como un ser sin identidad, al igual que los prisioneros del sistema Auburn. El ambiente de opresión y deformación de Elisa es la cárcel; pero el de Santa es la ciudad moderna. Así, tanto Goncourt como Gamboa, y a diferencia de Zola, van más allá del típico uso decimonónico de la figura de la prostituta como metáfora de las

una voluntad de advertir al púbico sobre la novela. Al utilizar la palabra joven los lectores no necesariamente estarían al corriente de que la protagonista del texto es una prostituta. Explicitar el oficio del personaje en el título permite amonestar, desde el punto de vista moral, a los que se presten a este tipo de lecturas, así como promocionar el texto ya que indudablemente las historias de prostitutas encendían la imaginación e interés del público lector. 
enfermedades sociales de la nación. Por el contrario, los dos se enfocan en la disolución del yo de sus personajes como consecuencia de la modernidad. En este sentido, más que la Nana mexicana, Santa es la Elisa mexicana.

Las diferencias entre la postura de Nana y Santa frente a su oficio son evidentes. En primer lugar, Nana deja su hogar para dedicarse a la prostitución por su propia voluntad; Santa es expulsada de su núcleo familiar y se dirige a la casa de doña Elvira porque no le queda remedio. Nana es el último eslabón de una inevitable cadena de putrefacción social y moral mientras que Santa es más bien una víctima de su entorno urbano y de sus circunstancias sociales. De Nana dice el narrador: "une fille, née de quatre ou cinq générations d'ivrognes, le sang gâté par une longue hérédité de misère et de boisson, qui se transformait chez elle en un détraquement nerveux (...) elle devenait une force de la nature, un ferment de destruction (...) corrompant et désorganisant Paris entre ses cuisses de neige" (204-05). Por el contrario, Santa recibe un "furioso galopar de personas (...) agresivo idéntico al de los garañones de las dehesas que encendidos en bestial lascivia nada los contiene (...) Puede decirse que la entera ciudad concupiscente pasó por la alcoba de Santa, sin darle tiempo casi de cambiar de postura. ¡Caída! ¡Caída la codiciaban! (84). En Nana es la protagonista quien pervierte a la ciudad entre sus níveos muslos mientras que en Santa es a la inversa, la sociedad urbana corrompe tanto su cuerpo como su alma. ${ }^{95}$

\footnotetext{
${ }^{95}$ En Nana se cifran las características de la imagen de la tan temida femme fatale finisecular, que mencioné con anterioridad en este capítulo, esa que utiliza su sexualidad para obtener lo que desea y destruir a los hombres que caen en sus manos. Santa, más allá de lo que su trabajo requiere, no seduce a ningún personaje masculino de manera clara. Tampoco obtiene ningún beneficio de ellos. Más bien es ella la seducida y engañada, empezando por Marcelino Beltrán, el militar que la deja embarazada y cuyo abandono le vale la expulsión de su núcleo familiar. Desde este punto de vista, con Nana (y me refiero tanto a la novela como a la protagonista) Zola analiza las causas biológicas y sociales de ese arquetipo de mujer considerado como pérfido por la sociedad occidental de principios del siglo XX.
} 
La enfermedad de Nana es hereditaria, ineludible y la protagonista la contagia a quien entra en contacto con ella. Santa, por el contrario, era robusta y saludable a su llegada a la Ciudad de México donde se enferma ya que los clientes más que sensual apetito tenían "ansias de estrujar, destruir y enfermar esa carne sabrosa y picante" (83). Queda claro entonces que Gamboa sí se afinca, aunque de manera distinta a Zola, en el segundo pilar del naturalismo: el determinismo social. La formación o más bien deformación de Santa es responsabilidad de su medio; la diferencia está en que el entorno responsable no es, como cabría esperar, las zonas más abyectas de la Ciudad de México sino la urbe moderna como un todo. El mal moral en contra del que se advierte en Santa no es la prostituta ni el burdel como tal sino la sociedad que denigra, pero a la vez ampara y fomenta ambas figuras. Santa repite en la novela:

¡No tenía culpa! ¡No se declararía culpable nunca! Que escudriñasen su juventud, su infancia; que cavaran en su corazón (...) ¡A que no cavaban! já que se conformaban con besarle y aplastarle sus senos erectos y macizos, sin curarse de que debajo de ellos latiera su corazón desconsolado (...) Y pues pedíanle sólo el cuerpo, sólo el cuerpo les daría, hasta que se saciaran ó también se lo enfermasen. (251-52)

Del extracto anterior se desprende que es la sociedad la responsable directa de la enfermedad (tanto moral como física) de Santa.

Manuel López Gallego plantea que los Bildungsromane no suelen contemplar la muerte del héroe y que en líneas generales terminan con un final feliz (acomodo social) o, al menos, con un final que no suponga daños irreparables para el protagonista (63). Resulta evidente que este no es el caso de Santa. Dentro del orden decimonónico establecido, un 
acomodo social real y significativo resultaba imposible para la protagonista de Gamboa. De allí que la redención de Santa no se dé en vida sino después de su muerte a través de la absolución de Dios y de los lectores. Por otro lado, Joan-Carles Mèlich asevera que, a diferencia de los Bildungsromane, las novelas de deformación, presentes según el crítico desde principios del siglo XX, están caracterizadas por la pérdida, parcial o total, de la subjetividad e identidad del protagonista y que es por esta razón por la cual el héroe perece física o substancialmente (171). Tal es el caso de Santa.

La merma de la identidad del personaje principal de Gamboa es evidente a la largo de la novela; en la primera parte del texto es gradual, pero en la segunda es vertiginosa. La pérdida del yo es definitiva una vez que la protagonista llega al último prostíbulo donde trabaja y pierde su nombre. Ya no es Santa sino Loreto: "y hasta el nombre encantador se ahogó en la ciénaga" (348). ${ }^{96}$ Mèlich señala al respecto: "si el nombre propio es la forma que tenemos para identificarnos como sujeto, la ausencia de nombre indica la disolución de la subjetividad" (179). Desde este punto de vista, Santa perece incluso antes de su muerte física.

Mientras Santa conserva su nombre, mantiene también algo de su identidad inicial, de muchacha provinciana de familia; es por esta razón que con frecuencia la atacan culpas,

${ }^{96}$ Por otro lado, lo único que Santa tiene de valor, bajo los parámetros de compra y venta capitalista, es su cuerpo, pues es una joven hermosa, y su nombre. La misma Pepa le señala a la joven a su llegada al prostíbulo: "Santa! Sólo tu nombre te dará dinero, ya lo creo; es mucho nombre ese" (17). Era (y aún es) común que las prostitutas modificaran su nombre de pila mientras trabajaban por uno que los clientes consideraran más sensual y apetecible. No es necesario que la protagonista de Gamboa cambie su nombre pues este satisface la voluntad censurada, pero presente, de los individuos de desacralizar algo/alguien que se presenta como sagrado. Cuando llega al último prostíbulo Santa ya se encuentra enferma, por lo que no tiene los encantos de su cuerpo que antes la hacían famosa; al perder también su nombre queda devaluada por completo en el mercado de consumo. Así su disuelve tanto su subjetividad como su valor económico haciéndola invisible como individuo e inservible como mercancía. 
remordimientos y arrepentimientos. En este sentido, y tal como señala Adriana Sandoval, Santa representa también el arquetipo de la virgen mancillada, la mujer que ensucia su cuerpo, pero cuya alma permanece pura (17). Así pues, ambos nombres de la protagonista resultan significativos. ${ }^{97}$ De hecho Hipólito le dice a Santa cuando la rescata: "Tú has sido una feliz, pues se me figura á mí que ni con parar en lo que paraste no te manchaste por dentro...apuesto á que en el fondo eres buena, ¿verdad que sí?” (360). Así la prostituta es absuelta y la ciudad moderna condenada.

Con Santa, y me refiero aquí tanto a la novela como al personaje, Gamboa reta al discurso hegemónico de la modernidad impulsada por Porfirio Díaz al revelar la corrupción y la falta de moral de los habitantes de la capital mexicana, así como el poder destructor de esa urbe y sociedad supuestamente progresista y moderna. No obstante, Federico Gamboa fue un individuo casi tan contradictorio como la modernidad de su ciudad natal ya que criticó con dureza los efectos de los proyectos modernizadores, pero nunca al dictador que los llevó a cabo, Porfirio Díaz, para el cual trabajó la mayor parte de su vida. A pesar de esto, y a partir de los diarios personales de Gamboa, podemos asumir que el autor de Santa estaba consciente de las críticas que exponía en su novela y lo que estas podrían costarle: "Algunos de mis "mejores amigos" han declarado que un libro así sólo debiera escribirlo un independiente, no un empleado como yo, al que novela semejante quizá les cueste la torta" (Schlickers 145). Esta entrada data de diciembre de 1903, el mismo año de publicación de Santa.

\footnotetext{
${ }^{97}$ El primer significado de la palabra santo que aparece en el diccionario de la Real Academia Española es: "perfecto y libre de toda culpa". El tercero indica: "dicho de una persona de especial virtud y ejemplo". Por otro lado, Loreto es el nombre con el que se conoce a una de las advocaciones de la Virgen María, Nuestra Señora de Loreto, desde aproximadamente el siglo XIII.
} 
A pesar de las artimañas de Gamboa, la denuncia contenida en Santa resulta evidente desde el inicio para un lector atento pues el mensaje del texto se cifra en el epígrafe: "Yo les daré rienda suelta; no castigaré á vuestras hijas cuando habrán pecado, ni á vuestras esposas cuando se hayan hecho adúlteras; pues que los mismos padres y esposos tienen trato con las rameras...Por cuya causa será azotado este pueblo insensato que no quiere darse por entendido" (III). Gamboa toma la cita de la Biblia, de Oseas; uno de los profetas del antiguo testamento que en su libro vaticina la decadencia del pueblo de Israel que se dedicó a adorar dioses falsos (como el becerro de oro). En este sentido Santa no es un cautionary tale, como algunos críticos han querido ver, ni un análisis patológico, al estilo naturalista, del mal moral de un individuo. Es más bien una profecía de la ciudad devoradora de individuos que se perfilará de manera más clara en novelas urbanas posteriores, así como también un señalamiento a esa clase social encargada de dirigir la nación que achaca de forma constante la responsabilidad del fracaso del progreso a individuos que, como Santa, carecen de agencia y autonomía dentro del orden social y político de la modernidad.

\section{Conclusión: Las contradicciones de la modernidad a través de la experiencia urbana del individuo y su devenir como ciudadano moderno}

Mikhail Bakhtin divide los Bilgunsromane en cinco categorías diferentes; de las cuales considera a la quinta como la más significativa:

In the four preceding types, man's emergence proceeded against the immobile background of the world, ready-made and basically quite stable (...) The world, existing and stable in this existence, required that man adapt to it, that he recognize and submit to the existing laws of life. Man emerged 
but the world did not (...) The world, as an experience and as a school, remained the same, fundamentally immobile and ready-made, given (...) (In the fifth category) He emerges along with the world and he reflects the historical emergence of the world itself . He is no longer within an epoch, but on the border between two epochs, at the transition point from one to another. This transition is accomplished in him and through him (...) It is as though the very foundations of the world are changing, and man must change along with them. Understandably, in such a novel of emergence, problems of reality and man's potential, problems of freedom and necessity, and the problem of creative initiative rise to their full height. (23-24)

En las novelas de formación tradicionales el acomodo social resultaba posible ya que la sociedad y su conjunto de reglas permanecían estables e inamovibles. La modernidad (tanto en Europa como en Latinoamérica) sacudió estas bases; cuestión que alteró el proceso de formación de los individuos y los ciudadanos. Ídolos rotos y Santa entran en esa quinta categoría de Bildungsroman de la que habla Bakhtin. El entorno urbano de Alberto Soria y de Santa no es estático y a ambos personajes se les dificulta reconciliar su potencial, creatividad y/o situación personal y social con el cambiante y confuso mundo que los rodea.

Bakhtin agrega además que la naturaleza de este tipo de Bildungsroman es cronotrópica ya que el devenir del individuo es inseparable del devenir histórico y espacial (23). No se puede entender la ciudad moderna sin los individuos que la viven y habitan y viceversa. Las transformaciones del medio están entonces unidas de forma irrevocable a las del individuo; pero ambas se desarrollan de manera diametralmente opuesta: tal como 
proponen Gamboa y Díaz Rodríguez, mientras la ciudad se moderniza, el individuo y su identidad se diluye y/o destruye (tema que abordará la novela de ciudad a partir de la segunda mitad del siglo XX). Así, el proceso (de)formativo de Alberto Soria y Santa es representativo del contexto urbano finisecular latinoamericano.

Como se desprende del análisis presentado en este capítulo, Ídolos rotos y Santa presentan ciudades que ya no son capaces de formar individuos, sino que más bien los deforman; postura que desafía el discurso oficial de la modernización latinoamericana como un proceso meramente positivo. Estas novelas relatan el fracaso de la modernidad a nivel individual. La experiencia de Alberto Soria y de Santa se unifican ya que, a finales del siglo XIX, el artista y la prostituta son dos caras de la misma moneda (Epple 38). Ambos son víctima de la inhumanidad del materialismo burgués; son vendedores y al mismo tiempo mercancía y son amados y al mismo tiempo repudiados por su entorno gracias a esta duplicidad. Su condición de ciudadanos es cuestionada ya que son individuos necesarios para el orden social, pero a la vez no son considerados como sujetos útiles para la modernidad y el progreso de la nación. Marianne Hirsh señala que "in a world where the self is but an object to be bought and sold, the notion of self-discovery and self- fulfillment becomes meaningless" (309). De allí que ninguno de los dos personajes alcance ni el acomodo social ni la realización personal.

En el proceso formativo que presentan los Bildungsromane está implícita tanto la búsqueda de la madurez social como la personal. Por lo tanto, en estas narraciones está presente el asunto de la construcción de la identidad del ser. La crisis del sujeto que inicia el proceso de formación en los Bildungsromane tradicionales no concluye en las novelas de Díaz Rodríguez y Gamboa con la llegada del individuo a sí mismo sino con el inicio de 
la disolución. Mèlich propone que el proceso de "des-identidad" que se desencadena en las novelas de deformación se inicia precisamente con la alienación del sujeto, continúa con su deformación y concluye con su desaparición (182). Como he demostrado a lo largo de este capítulo, tanto Alberto Soria como Santa son alienados por su entorno, cuestión que desfigura el proceso de madurez de ambos personajes. Santa cierra con el fallecimiento de la protagonista y si bien es cierto que Gamboa le otorga al personaje una redención espiritual después de su muerte resulta evidente que el proceso "formativo" solo podía culminar con la destrucción tanto del ser físico como de la identidad de Santa. Alberto Soria, por su parte, no muere al final de la novela; no obstante, desaparece simbólicamente al autoexiliarse de la patria. La identidad personal del protagonista de Ídolos rotos está ligada a su condición de artista, a sus ideales estéticos y a su obra; por esta razón el fracaso determina su actitud hacia el terruño. Su entorno impide tanto su desarrollo artístico como su desarrollo personal y, en este sentido, mata metafóricamente al personaje a pesar de que este no perezca de forma física.

Christopher Conway señala que la ciudad latinoamericana a finales del siglo XIX e inicios del XX fue más que un espacio, una idea ligada a palabras claves como progreso y civilización. Sin embargo, la ciudad también fue un escaparate de la característica más alarmantes de la vida moderna. Esta faceta de la experiencia urbana desafió la idea de que la ciudad, y por extensión, la modernidad que se suponía que debía encarnar, podía promover un cambio social positivo (50). En Santa e Ídolos rotos queda en evidencia que estos rasgos alarmantes de los que habla Conway no son la tan temida barbarie o las zonas abyectas de la ciudad sino la modernidad misma que, encarnada en la urbe y su sociedad, es capaz de deformar a sus ciudadanos y destruir tanto su desarrollo social como personal. 


\section{CAPÍTULO IV}

Delincuencia y criminales: la ciudad subalterna y la otredad urbana en La rumba de

$$
\text { Ángel de Campo y El conventillo de Luis Pascarella }
$$

Benjamín Vicuña Mackenna, intendente de la ciudad de Santiago de Chile de 1872 a 1875, elaboró, siguiendo los pasos del Barón Haussmann, responsable de las renovaciones de París, un detallado documento titulado La transformación de Santiago: Notas e indicaciones respetuosamente sometidas a la Ilustre Municipalidad, al Supremo Gobierno y al Congreso Nacional donde enumera, en orden de importancia y apremio, las reformas necesarias "no solo para embellecer Santiago sino para salvarlo" (7). Se entiende entonces que la modernización de las urbes latinoamericanas implicaba, al menos en teoría, más que el ornato urbanístico. Una ciudad moderna y civilizada debía ser una ciudad segura para sus habitantes y muchas de las capitales latinoamericanas aún batallaban con numerosos factores de peligro, como la indomable naturaleza del continente que las rodeaba y acechaba en todo momento. De allí que Vicuña Mackenna abra la lista de renovaciones con la necesidad de canalizar del río Mapocho, que atravesaba parte de la ciudad y que con frecuencia se desbordaba durante el invierno anegando Santiago. El intendente es tajante: "Este proyecto no admite discusión. Es una necesidad pública antigua" (12). ${ }^{98}$

Otro asunto importante para garantizar la seguridad de los ciudadanos modernos era la higienización del espacio urbano; por esta razón Vicuña Mackenna continúa el listado proponiendo la construcción del Camino de Cintura. Esta especie de circunvalación

\footnotetext{
${ }^{98}$ Las crecidas del río Mapocho han sido un problema constante para los habitantes de Santiago de Chile, incluso en el siglo XXI. El último gran desborde del río sucedió en abril del 2016.
} 
pretendía, a primera vista, evitar el tráfico excesivo en el centro urbano, así como establecer una separación entre la ciudad y las incipientes zonas industriales que albergaban fábricas que podían emitir emanaciones nocivas para la salud pública. No obstante, la función limítrofe del Camino de Cintura no se limitaba a separar la zona residencial de Santiago de la industrial:

Define (el Camino de Cintura) la ciudad estableciendo los límites propios de ésta, demarcacion que hoi dia forma una de sus mas imperiosas necesidades, con relacion a la edilidad, (es decir al pavimento, las aceras, las plantaciones, el alumbrado, la seguridad, el uso del agua potable etc.), creando la ciudad propia, sujeta a los cargos i beneficios del municipio, i los suburbios, para 1os cuales debe existir un réjimen aparte, menos oneroso i menos activo. ${ }^{99}(18)$

En la actualidad, los suburbios de las capitales hispanoamericanas suelen ser zonas residenciales de clase media-alta. En líneas generales se les considera como áreas más seguras ya que están alejadas del centro urbano y sus problemas (tráfico, ruido, crimen, suciedad, etc.). Por el contrario, en el siglo XIX, era la periferia social, económica, racial y cultural de la ciudad la que habitaba el extrarradio urbano. Richard Dennis, por ejemplo, señala que el adjetivo suburbano ya era considerado un término peyorativo a principios del siglo XIX (179). De la cita de Vicuña Mackenna se desprende la voluntad de separar y delimitar de manera tajante la ciudad de los suburbios, así como la intención de concentrar

\footnotetext{
${ }^{99}$ Las cursivas de la cita forman parte del texto original.
} 
tanto el peculio como la planificación urbana (y, por extensión, la modernización) solo en la ciudad propia.

El tercer punto en la larga lista de renovaciones de Vicuña Mackenna es precisamente la necesidad de transformar los suburbios ubicados al sur de Santiago. Dice el intendente:

He aquí una de las mas vitales necesidades de la ciudad, sino la mas capital de todas. Es un deber de filantropía, de honra, de salvacion. Conocido es el orijen de esa ciudad completamente bárbara, injertada en la culta capital de Chile i que tiene casi la misma área de lo que puede decirse forma el Santiago propio, la ciudad ilustrada, opulenta, cristiana. (23)

La utilización del muy mentado adjetivo de bárbaro justificaba, a ojos de los intelectuales y políticos liberales del momento, la eliminación de los suburbios. No podía haber civilización si se convivía con la barbarie, la cual en las últimas décadas del siglo XIX acechaba más de cerca pues no solo se ubicaba en el lejano campo sino en las puertas de la ciudad e, incluso, en la urbe misma. Así, en el imaginario de la intelectualidad finisecular, las capitales se desdoblaban en dos: la moderna y la bárbara. ${ }^{100}$ Richard Dennis señala al respecto: "rather than suburbs being merely subordinate to cities, they came to be seen as oppositional, more nature than culture, rural than urban, female than male, private than public" (179). ${ }^{101}$

\footnotetext{
${ }^{100}$ En su estudio de las ciudades latinoamericanas, Cristopher Conway bautiza esta dualidad de la urbe como "the city of light" (25) vs. "the dark city" (32).

101 Resulta significativo entonces que las protagonistas de las tres novelas que abordan los espacios marginales urbanos y/o suburbanos sean mujeres: Santa en Santa de Federico Gamboa, Remedios Vena en La rumba de Ángel de Campo y Ana María Capizzi en El conventillo de Luis Pascarella.
} 
La propuesta de Vicuña Mackenna en cuanto a la ciudad "bárbara" es mucho menos precisa, en términos de inversión y planificación, que las proposiciones anteriores y se limita a sugerir la destrucción de las edificaciones localizadas en el área —conventillos y ranchos en su mayoría. No se hace referencia a posibles mejoras en cuanto a la infraestructura y los servicios básicos a pesar de que se reconoce que son estos los principales sospechosos de causar la proliferación de gérmenes y enfermedades que de manera constante azotaban la zona. Esta eliminación implicaba una depuración arquitectónica pero también social, económica, racial y cultural. Y es que la supuesta seguridad de los ciudadanos a la que se aspiraba a finales del siglo XIX y principios del XX involucraba deshacerse de la otredad urbana que amenazaba con su sola presencia la posición e intereses de la clase dirigente. ${ }^{102}$

Si bien es cierto que la literatura del momento, en líneas generales, no expuso ni planteó de manera tan evidente y severa la supresión de ciertas zonas geográficas urbanas y sus respectivos moradores; resulta evidente, en el silencio o la omisión de estos espacios y sus habitantes, que muchos escritores compartían, al menos hasta cierto punto, la posición de Vicuña Mackenna. A pesar de los títulos totalizadores tanto La gran aldea como Todo un pueblo circunscriben sus espacios al centro urbano y la élite de Buenos Aires y Caracas. Lo mismo sucede con Ídolos rotos. Tan solo en Santa aparece la periferia geográfica urbana, representada en el barrio de clase obrera en el que se localiza la casa de doña Elvira

\footnotetext{
${ }^{102}$ En el capítulo III abordé el problema de la ciudadanía a finales del siglo XIX. Adriana Bergero señala que la ciudadanía se definía en base a la nacionalidad, la edad, el género, el estatus económico y la educación (5). Es decir, para la época solo eran considerados ciudadanos, con derechos y deberes para con el Estado, los hombres blancos de cierto nivel económico. Por esta razón cuando se habla de la seguridad de los ciudadanos no se toma en cuenta el bienestar de esos habitantes del extrarradio urbano que eran en su mayoría individuos pobres y de color (negros, indios, mestizos, mulatos, etc.)
} 
y en los arrabales en los que cae la protagonista una vez que enferma. Por otro lado, de todas las novelas abordadas hasta el momento, solo en el personaje de Santa se exponen rasgos raciales, sociales y/o económicos de la otredad urbana. ${ }^{103}$ Las novelas de ciudad finiseculares suprimieron de manera voluntaria la heterogeneidad del tejido social urbano para representar una sociedad moderna caótica, viciosa, de moral enferma pero siempre medianamente blanca, adinerada y homogénea. Novelas como La rumba (1890-91) del mexicano Ángel de Campo y El conventillo (1917) del argentino Luis Pascarella rompen con esta línea de pensamiento y no solo visibilizan esa supuesta ciudad bárbara, sino que además la abordan desde un punto de vista novedoso que cuestiona y a la vez desafía el andamiaje ideológico sobre el que se construyó la modernidad latinoamericana.

\section{La rumba: la urbe y el discurso criminológico}

El mexicano Ángel de Campo, también conocido como Micrós o Tick Tack, ${ }^{104}$ publicó en veinte entregas, que aparecieron en el periódico El Nacional entre 1890 y 1891, su novela más conocida: La rumba. El texto narra la historia de Remedios Vena, una joven, hija de un herrero, nacida y criada en La Rumba, un barrio pobre suburbano de la Ciudad

\footnotetext{
${ }^{103}$ Es cierto que la pareja protagónica de Todo un pueblo, Julián Hidalgo e Isabelita Espinoza, son mestizos al igual que Santa; sin embargo, el tratamiento de los tres personajes es bastante diferente. En el caso de Isabelita, su condición racial se menciona, pero se obvia del resto de la narración. Aunque la muchacha es menospreciada por los miembros de la antigua clase patricia, tiene una situación si no social al menos económicamente ventajosa debido a los negocios de su padre. La condición de mestizo de Julián sí se recalca a lo largo del texto; no obstante, y al igual que Isabelita, su situación económica es holgada pues es propietario de tierras heredadas de su familia. En el personaje de Santa, por el contrario, y como ya señalé en el capítulo anterior, sí se suman todos los rasgos de esa otredad que habitaba de manera anónima el extrarradio urbano: es mestiza, de provincia y carece tanto de posición social como de medios económicos.

${ }^{104}$ Ignacio Manuel Altamirano, célebre escritor realista de la época y maestro de De Campo, lo apodó Micrós debido a su baja estatura (Olea Franco 13). De Campo comenzó a utilizar el mote como uno de sus muchos seudónimos bajo los cuales escribió la mayor parte de su obra.
} 
de México. La mayor aspiración de Remedios era vivir en la ciudad y ser como las rotas. ${ }^{105}$ Para lograr sus objetivos entra a trabajar en la casa de modas de Madame Gogol, una popular modista parisina, y en el recorrido que hace todos los días a la capital conoce a Napoleón Cornichón, un barcelonete del que se enamora y con el que termina viviendo en una casa de vecindad en la capital. ${ }^{106}$ Sin embargo, la realidad de Remedios en Ciudad de México resulta ser muy diferente a sus sueños de infancia en La Rumba cuando veía las luces de la ciudad a lo lejos. La casa de vecindad donde se muda poco tiene de la ampulosidad moderna que se desplegaba en el centro de la urbe y Cornichón se devela como un hombre bebedor, flojo, celoso y agresivo. Una noche, en medio de una discusión acalorada, Napoleón amenaza a Remedios con una pistola; en medio del forcejeo el arma se dispara, mata a Cornichón y lleva a Remedios a la corte donde es juzgada por el supuesto homicidio de su amante.

La novela de De Campo no se concentra en el esplendor de la Ciudad de México moderna, sino que, por el contrario, y como se revela desde el título, se enfoca en un suburbio de la capital mexicana. De hecho, el texto abre con la descripción del aspecto físico del barrio y sus moradores. Carlos Pineda considera este inicio como el retrato más

\footnotetext{
105 El diccionario de la Real Academia Española indica que rota(o) es un mexicanismo que significa petimetre. Esta palabra, que deriva a su vez del francés petit maître, es sinónimo de señorito(a) y se utiliza para describir a alguien que se preocupa mucho de su aspecto físico y de seguir las modas. En Chile, por el contrario, la palabra roto(a) se utiliza para denominar a personas pobres (casi siempre de origen urbano).

${ }^{106}$ Barcelonnette es una localidad francesa ubicada al sureste del país, cerca de la frontera con Italia. A partir de la segunda década del siglo XIX se inició un proceso de inmigración, casi siempre masculina, de esta zona de Francia a México que luego se consolidó durante el mandado de Maximiliano I de México. En esta época llegó a haber comunicación marítima mensual entre Barcelonnette y Veracruz. A estos inmigrantes se les conocía como barcelonetes en México. Durante el porfiriato los barcelonetes se dedicaron, en su mayoría, a la industria textil y establecieron grandes almacenes de telas, ropas y artículos del hogar en Ciudad de México. Algunos de ellos, como por ejemplo la tienda El puerto de Liverpool, fundada en 1847, aún mantienen sus puertas abiertas hoy en día.
} 
afortunado del espacio público marginal de la novelística mexicana del siglo XIX (114). La imagen que se presenta es desoladora pues en La Rumba predominan las ruinas, la suciedad y el silencio; rasgos contrarios a la moderna Ciudad de México con su arquitectura francesa, su bullicio incesante y su preocupación constante por la salud y la higiene. De los hombres que viven en La Rumba se dice que tienen "rostros patibularios, amarillentos, de mirar siniestro" (7). Es decir, se trata de criminales; después de todo, la propia voz narrativa indica que:

La Rumba tenía fama en los barrios lejanos; contábase que era el albergue de las gentes de mala alma; una temible guarida de asesinos y ladrones, y citaban el nombre de un Florencio Carvajal, que debía siete vidas; Marcos Pezuela, zapatero, había envejecido en Belén y después de extinguir su condena se había refugiado en aquel vivero de malhechores. ${ }^{107}$ (5)

A primera vista, estas descripciones encajan con la posición de Benjamín Vicuña Mackenna quien, en sus mencionadas propuestas de renovación de la ciudad de Santiago de Chile, señala que los suburbios urbanos son "una inmensa cloaca de infección i de vicio, de crimen y de peste" (24-25). De estas citas se desprende que, tanto en los textos de ficción

\footnotetext{
${ }^{107}$ La cárcel de Belén se instauró en 1863 como modelo de prisión moderna e higiénica que, en teoría, contemplaría la rehabilitación del reo y no solo su castigo. A ella se trasladaron los presos de la cárcel de la Acordada, que databa de la época colonial (1781). La idea de rehabilitar el edificio de Belén, que antes de la independencia de México había albergado el Recogimiento de San Miguel de Bethlem para mujeres pobres, viudas y solteras y, más tarde, el Colegio de niñas pobres de San Miguel de Bethlem, se originó en la necesidad de mover la cárcel del área donde estaba localizaba la Acordada. El edificio que albergaba la antigua prisión había sufrido los estragos del terremoto de 1788 y de numerosas inundaciones y, además, se encontraba cerca de la Alameda Central, uno de los jardines públicos de Ciudad de México. Por supuesto, en una ciudad moderna el espacio de castigo no debía colindar con el de recreación. Las buenas intenciones de la nueva cárcel de Belén duraron poco: para le época de publicación de La rumba, Belén albergaba cerca de 2000 reclusos en un espacio destinado a 600. El hacinamiento de personas, así como la falta de inversión en infraestructura y recursos (alimentación y camas para los reos, por citar un par de ejemplos) trajo como consecuencia el contagio masivo de enfermedades.
} 
como en los documentos oficiales de planeamiento urbanístico, se hizo uso del discurso médico y la criminología como herramientas de justificación de las políticas de exclusión instauradas y mantenidas por la clase dirigente. Al lector contemporáneo la medicina y la criminología pueden quizás parecerle disciplinas sin nexo alguno. No obstante, este no es el caso, y muchísimo menos lo era a finales del siglo XIX y principios del XX.

El italiano Cesare Lombroso (1835-1909) fue el fundador de los que se conoce como la Escuela de Criminología Positivista. Lombroso proponía que las causas de la criminalidad eran biológicas pues el criminal nacía con características natas que lo impulsaban de manera irremediable al acto delictivo. Estos rasgos atávicos que Lombroso identifica eran, a su modo de ver, muestras claras de que los criminales constituían un estado evolutivo anterior al del hombre que se comportaba dentro de los parámetros de la ley. ${ }^{108}$ Estos postulados señalaban la existencia de discrepancias a nivel biológico entre estos seres bárbaros y los ciudadanos civilizados. Estas diferencias se manifestaban a su vez en rasgos físicos como la asimetría del rostro y el tamaño del cráneo. De allí que en la época hayan proliferado ciencias, hoy en día desacreditadas, como la frenología, que estudiaba el peso, forma y tamaño del cráneo para determinar las tendencias criminales de una persona, o la personología, que estudiaba la correlación entre los rasgos físicos y la conducta y carácter moral del individuo. Por ejemplo, Rebolledo, el periodista encargado de escribir el reportaje sobre el caso de Remedios afirma el día del juicio: "Hay mucha

\footnotetext{
${ }^{108}$ Por el contrario, la escuela anterior, la llamada Escuela de Criminología Clásica, se basaba en los postulados de la Ilustración y consideraba que todos los individuos eran seres iguales y racionales; es decir responsables de sus actos. Bajo estos parámetros el acto delictivo partía del libre albedrío de cada persona; por lo tanto, cualquiera podría tener o no un comportamiento que quebrantara la ley. Para la Escuela Clásica no había una diferencia innata e identificable entre el que violaba la ley y el que la respectaba.
} 
gente de La Rumba- en la cara se les conoce, son de fama" (106). Esta postura también explica por qué, cuando se estudiaba a los criminales encarcelados en las prisiones locales, se tomaban fotos de sus rostros pues la imagen constituía un elemento necesario para el estudio de la fisonomía. Las fotos no se usaban como método de registro de la cárcel (como se utilizan hoy en día) sino como herramienta de análisis. Con todo lo anterior, resulta evidente que, para el momento, el estudio de la criminalidad implicaba un diagnóstico médico del delincuente para identificarlo, aislarlo y así proteger a la sociedad. ${ }^{109} \mathrm{Al}$ respecto, Michel Foucault señala que la patología se utiliza como forma general de regulación en sociedades donde jamás se cuestiona la autoridad del diagnosticador ( $\mathrm{La}$ vida... 113).

Ya que la apariencia física del individuo revelaba al delincuente; de la misma manera, la fisonomía del espacio urbano daba cuenta del tipo de moradores que habitaban en la ciudad. Se entiende entonces la insistencia de Vicuña Mackenna por separar, tanto de forma retórica como física, a Santiago de Chile del extrarradio urbano. En el análisis de textos como La gran aldea e Ídolos rotos realizado en capítulos anteriores he señalado la tendencia a identificar a los personajes femeninos con la ciudad; no obstante, en la novela de De Campo la simbiosis entre la protagonista y el barrio que habita alcanza nuevos niveles. Y es que Remedios es conocida con el apodo de la Rumba. Así, si el barrio tiene fama de ser el hogar de delincuentes pues la protagonista no puede sino presentar las características atribuidas a los criminales.

\footnotetext{
${ }^{109}$ El propio Cesare Lombroso era médico. Se graduó de la Universidad de Pavía en 1858.
} 
Con respecto a la mujer criminal, Lombroso señala que uno de los rasgos más evidentes para identificarla es la precocidad sensual (374). De Remedios, cuando es aún niña, dice la voz narrativa:

Rasgaban casi su estrecho vestido las formas precozmente desarrolladas, con enérgicas curvas. Era muy niña; pero en sus ojos de dulzura infantil, cruzaban a veces esos relámpagos elocuentes, esas miradas de mujer que en nada se parecen al candor. Acentuábase el relieve de sus labios de sonrisa impúdica, acorde con la nariz picarescamente arremangada y el andar atrevido, el ademán provocativo de la muchacha, la más bonita del barrio.

Por otro lado, la mayor ambición de Remedios era ser como las rotas y su felicidad máxima, durante la temprana adolescencia, era vestirse para ir al centro de la ciudad (12). Este pasatiempo de apariencia inofensivo da a entender la peligrosidad de una niña como Remedios pues, según Lombroso, las criminales mostraban una preferencia marcada por la vida aventurera, disipada y elegante en una gran ciudad (435). Remedios es además hija de un borracho y, tal como señala Joan Torres-Pou, la criminología veía en la bebida una de las causas primordiales de los delitos en los barrios pobres ("Técnicas y discurso" 32). ${ }^{110}$

Remedios crece y se convierte en: "una mujer hermosa, una de esas que ponen fuera de sus casillas a los devotos de lo monumental, y ella lo era por su alta estatura, su robustez y aquel aire de diosa guerrera de su rostro, aquel mirar que penetraba hasta la médula y aquella sonrisa nada mística de sus labios gruesos, rojos, húmedos y sanos” (14-

\footnotetext{
${ }^{110}$ En las obras de Zola, muy leídas en la época, se señala múltiples veces la ingesta excesiva de alcohol como una de las muestras de degeneración.
} 
15). Remedios se asemeja más a una amazona que a las damas delgadas, etéreas, débiles y rubias que solían poblar la literatura decimonónica/finisecular. Esta diferencia resulta de nuevo reveladora pues Lombroso asegura que el tipo físico de las amazonas solo se encuentra en las mujeres de pueblos bárbaros (67). Así, el retrato de Remedios da cuenta del supuesto estado evolutivo atrasado de la protagonista y, a la vez, prefigura la posibilidad del crimen, que se da al final de la narración. Entonces, si Vena es una mujer "bárbara", tampoco asombra que, a pesar de resaltarse su belleza, se hable de ella como de un animal: además de llevar el apodo de la Rumba, es conocida como la tejona (por tener la cara afilada) y sus modales en vez de delicados y femeninos son descritos como broncos y varoniles. ${ }^{111}$ Con esta descripción, el lector decimonónico no se sorprendería del proceder de Remedios pues existía un razonamiento biológico que explicaba la huida de la joven de su casa sin estar casada y el asesinato de su amante. No obstante, el lector atento puede conseguir en La rumba la denuncia del mismo discurso criminológico del que se hace uso.

En primer lugar, la voz narrativa no afirma que La Rumba sea un barrio de criminales, sino que tiene fama de serlo. Al inicio del texto se nombra a un asesino, Florencio Carvajal (que no vuelve a aparecer en la narración), y a un Marcos Pezuela que se muda a La Rumba luego de cumplir condena en la cárcel de Belén por un crimen que nunca se menciona (5). Lo que sí se señala es que Pezuela era zapatero y es así como, y casi de manera imperceptible, la narración revela que esos habitantes de rostros patibularios son tan solo humildes herreros, tenderos, maestros de escuela, costureras, vecinas

\footnotetext{
${ }^{111}$ La palabra bronco tiene en este contexto doble significado pues hace referencia al carácter hosco o áspero de Remedios y, a la vez, a su actitud inconforme pues en México se utiliza la palabra bronco para hablar de un caballo sin domar. En este sentido la protagonista de La rumba no ha sido domada pues no quiere conformarse con la vida que la sociedad le ha asignado a vivir dentro de los límites impuestos a su género y clase social.
} 
chismosas, etc. De Campo usa todas las características que la criminología asigna a un entorno social de delincuentes para concluir que La Rumba no es más que un simple barrio proletario (Torres-Pou, "Técnicas y discurso" 31). Otro tanto sucede con Remedios que, a pesar de ser hosca, supuestamente impúdica, fuerte y varonil, no es más que una pobre joven cansada de su miserable entorno:

Remedios trabajaba como un hombre: su padre el herrero, ebrio consuetudinario, la ocupaba en el oficio como a un oficial cualquiera; levantaba grandes barras, golpeaba con pesados martillos, mordíase la lengua, se bebía el sudor (...) Cuando su padre estaba ebrio y le arrojaba puñetazos, ella los paraba como un maestro de pugilato y daba lástima ver en su epidermis de capullo tierno los moretones, rastros de la cólera brutal del herrero (...) Amargas cosas que despertaban en su interior un deseo vago, no definido de algo que no fuera su existencia de bestia de carga (...) sentía una inmensa rabia de ser una cualquiera y casi sollozaba cuando oía a sus espaldas el roncar del fuelle, el choque del yunque, el chisporroteo de las brasas y a su frente miraba La Rumba, negra, sola, oliendo a muladar, poblada de perros hambrientos que aullaban: se ponía en pie, miraba a lo lejos, flotaba sobre la ciudad oscura y dormida, como una bruma luminosa, el reflejo de la luz eléctrica, murmuraba no sé qué frases, como si soñara en voz alta diciendo:

-Yo he de ser como las rotas... (12-13)

La obsesión de Remedios con Ciudad de México y con ser como las rotas no parte de la vanidad y la avaricia sino de un deseo de escapar a un medio embrutecedor y a un 
determinismo tanto social como biológico: ser siempre la hija pobre del herrero. La protagonista tiene la certeza de que puede deslastrarse de su destino prefigurado al salir del espacio geográfico de La Rumba. La imagen de las rotas implica, por un lado, la idea de lujos y vanidades, pero para Remedios constituye también el modelo de bienestar económico y material del cual los habitantes de La Rumba están privados. La ambición de ser como las rotas es superficial tan solo en apariencia pues revela un modelo sistemático de opresión de los individuos pertenecientes a la clase trabajadora. Entonces, el atrevimiento de Remedios no es emular a las rotas, en cuanto el deseo por el lujo excesivo puede resultar pernicioso (a pesar de que este argumento se esgrime repetidas veces en la novela, sobre todo durante el juicio de la protagonista); su gran transgresión es pretender salir de su entorno social y económico.

Remedios aspira a mejorar su condición no solo saliendo de La Rumba sino también a través del trabajo y la educación, ambos elementos vedados a la mujer decimonónica que, como ya he argumentado, estaba limitada al ámbito privado del hogar y debía ser tan solo esposa y madre (en este orden). No en vano afirma el cura de La Rumba cuando Porfiria, la madre de Remedios, le consulta qué hacer una vez que su hija huye de casa:

-(...) De que las muchachas, se van... mal negocio. ¿No se lo dije a usted? Señora, mientras no cuide usted a esa niña, nada bueno ha de salir. Si usted la hubiera puesto en un colegio...

-Iba a la escuela, padre.

—Pero, ¡a qué escuela! Sí, señor, ja qué escuela! A una escuela donde sabe Dios lo que las niñas aprenden, las amistades que entablan y las ideas que sacan. ¿Se acuerda usted cuando le propuse que mi tía la enseñara a 
bordar? No quiso la muchacha (...) Quería aprender física, y aritmética, y qué sé yo; cosas que de nada les sirven a las mujeres, cuyo porvenir está encerrado en el hogar, y para saber lo que en él se debe hacer, no se necesita geometría, sino buena educación. No me hicieron caso y allí tiene usted el fruto (...) Pretextos, señora, pretextos para andar azotando calles (...)Todo eso ha venido de que quiere picar muy alto, sí; señora; no se conforma con ser lo que es, hija de un artesano, sino que quiere andar en bola con las de tapalito y botincito $(\ldots)$ —Por eso nunca adelantan ustedes —prosiguió el cura, sacudiendo el lacre, y golpeando con él el borde de la mesa — por eso, porque no se conforman con lo que son, y quieren estar más altas (...). (4344)

Durante la Colonia, época durante la cual no había una separación clara entre religión y Estado, el determinismo divino daba explicación a la posición social (y por extensión económica) de cada individuo, desde el rey y su familia hasta el último esclavo. Con el advenimiento de las repúblicas esta simbiosis se quebrantó por lo que, tal como asevera Torres-Pou, las élites se vieron en la necesidad de encontrar nuevos discursos que justificaran tanto su posición como la inmovilidad social y económica de aquellos que ocupaban escaños inferiores ("Técnicas y discurso" 28). Los discursos eugenésicos y criminológicos pasaron a cumplir la función justificadora que antes cumplía la religión; no obstante, y como se desprende de la cita anterior los representantes del clero siguieron apoyando el orden establecido a pesar de que el discurso utilizado fuese distinto. Remedios sí transgrede las normas, pero no porque asesina a su novio sino porque no se quiere 
someter a las estipulaciones impuestas por la élite patriarcal del momento. Esta es su gran falta.

En el juicio, la Rumba relata entre lágrimas lo ocurrido la noche de la muerte de Cornichón. Habla sobre las estrecheces económicas en las que vivían y sobre los celos y las agresiones del barcelonete. Finalmente cuenta cómo la amenazó con una pistola y el fatídico accidente. No obstante, el abogado acusador, de apellido Correas, pide la pena máxima para la joven con las siguientes palabras:

-No, señores - prosigue - no es cierto que haya sido un homicidio casual; lo que la procesada ha dicho aquí es una absurda fábula (...) no: este crimen es la consecuencia natural de una mala conducta, y la que tiene audacia para abandonar el hogar, la que entrega su honra en manos del primero que pasa, la que desprecia a un comerciante digno, ${ }^{112}$ la que riñe con frases de plazuela, esa, señores jurados, tiene también la sangre fría para matar a un amante. Señores, en nombre de la sociedad ofendida, pido un castigo para que las mujeres honestas vean que la justicia vela sobre ellas y las que se hallen en peligro sepan cómo condena el tribunal del pueblo a las que, en pugna con su sexo, se convierten en una amenaza para los hombres dignos.

\footnotetext{
${ }^{112}$ El comerciante digno al que se refiere Correas es Mauricio, un tendero asturiano de treinta y cuatro años radicado en La Rumba. Mauricio pretende a Remedios, pero ésta, deslumbrada por Cornichón y por la Ciudad de México lo ignora. La mención de Mauricio en esta cita es significativa pues Correas lo presenta como el candidato apropiado para Remedios pues pertenece a su mismo barrio y entorno social. De esta manera Remedios también es juzgada por no aceptar al pretendiente que la lógica del orden social establecido le otorgaba.
} 
De la cita anterior se desprende que el asesinato de Cornichón pasa a segundo plano y que Remedios es juzgada por no cumplir a cabalidad su papel de mujer pobre. Y es que el proceder de la protagonista entra dentro de los parámetros de conducta delictiva del momento: primero por ser prófuga del hogar paterno y, en un segundo lugar que irónicamente parece no tener tanta importancia, por sospechosa de asesinato (Pineda 119). Aunque parezca insólito, no es de extrañar que el asesinato de Cornichón se olvide dentro de los argumentos para condenar a Remedios pues la criminología positivista partía de la premisa de que se debía juzgar al individuo primero y luego sus actos. Carlos Roumagnac, uno de los discípulos más notables de las ideas de Lombroso en México, así lo especifica: "sin dejar de conceder importancia al crimen nos fijamos más en el criminal, que no olvidemos que antes que el acto está el hombre, en una palabra, que tratemos no solo de castigar el hecho, sino de impedir su repetición, suprimiendo las causas que lo engendraron" (8).

Seguir las propuestas de Roumagnac y eliminar la serie de elementos y situaciones que llevaron a Remedios a encontrarse en la escena del supuesto crimen suponía la destrucción de la estructura social republicana del México finisecular que mantenía tanto a las mujeres en general, como a los individuos de la clase social/racial de la Rumba sometidos a un método sistemático de opresión. La clase hegemónica patriarcal no estaba dispuesta a soportar, y muchos menos a propiciar, tales cambios por lo que la estrategia para evitar los actos delictivos debía ser distinta. Roumagnac define como delincuente a todo "individuo que comete algún acto contrario á los intereses de la sociedad" (14). Si tomamos como cierta la idea de Gisela Heffes que propone que las villas y favelas están situadas en una ambigua zona liminar a partir de la cual, y de manera simultánea. integran y no integran la 
ciudad (29); podríamos concluir que los habitantes de estas zonas marginadas formaban y a la vez no parte de la sociedad urbana a finales del siglo XIX. En este sentido, los "intereses de la sociedad" de los que habla Roumagnac son en realidad los intereses de las clases altas urbanas y no los de toda la población. Remedios debe entonces pagar por haber huido del hogar paterno, por haber vivido con un hombre sin estar casada, por haber querido escapar de La Rumba y por haber tenido el deseo y la voluntad de salir de unas condiciones de vida deplorables a través del estudio y el trabajo. De allí que varias de las preguntas del jurado no tengan nada que ver con la muerte de Cornichón: “¿La acusada fue anteriormente de buenas costumbres? ¿El crimen causó a la sociedad grande escandalo? ¿Causó grande alarma a la sociedad?” (127).

Remedios Vena es absuelta del homicidio de Cornichón; aunque no porque el jurado haya creído en su inocencia sino porque su aspecto físico desconcertaba: su belleza no encajaba con la monstruosidad que suponía el acto de asesinar. La protagonista de De Campo no paga condena en la cárcel de Belén, pero sí en La Rumba donde, a su regreso, consigue todas las puertas cerradas, incluyendo la de su familia. La voz narrativa indica: "o Belén o la calle; pero de todos modos la desgracia, porque ¿de qué sirve la absolución del pueblo cuando no absuelven los padres? ¿Cuándo no absuelven los amigos?” (127). Remedios rompe el status quo y por esta razón se le niega incluso la reinserción en su ambiente de origen. ${ }^{113}$ En estas últimas páginas de la novela se disocia la imagen del

\footnotetext{
${ }^{113}$ La historia de Remedios no resulta atípica en la literatura del momento pues con frecuencia se recurría a la figura de la costurerita que aspiraba a ascender socialmente y fracasaba en el intento. Aparece, por ejemplo, con mucha frecuencia en los textos de los poetas argentinos Evaristo Carriego y Andrés Cepeda. No obstante, el final de la Rumba es contrario a esta tradición ya que, como plantea Diego Armus, en estos textos el barrio y el hogar permaneces leales a la costurerita a pesar del abandono y de la peregrinación innecesaria a la ciudad: "El mal paso no es definitivo y el regreso a los orígenes es posible" (122). La salida de Remedios de La Rumba y del hogar paterno constituyen en el texto de De Campo traiciones imperdonables. De allí que la protagonista esquive la cárcel mas no el castigo.
} 
suburbio y de la protagonista que hasta este punto habían estado entrelazadas: "Era La Rumba, pero era una Rumba airada que parecía cerrar sus hogares para no dejarla entrar, una Rumba más triste que otras veces, una Rumba que la odiaba” (133). Remedios solo encuentra cobijo en la iglesia del barrio. No obstante, esta acción no responde a la premisa católica de perdonar y hacer bien al prójimo.

Michel Foucault establece que las funciones disciplinarias tradicionalmente asociadas al sistema de justicia y/o carcelario se extienden en el siglo XIX más allá de estos organismos:

Sería inexacto, sin embargo, creer que las funciones disciplinarias han sido confiscadas y absorbidas de una vez para siempre por un aparato del Estado. La “disciplina” no puede identificarse ni con una institución ni con un aparato. Es un tipo de poder, una modalidad para ejercerlo, implicando todo un conjunto de instrumentos, de técnicas, de procedimientos, de niveles de aplicación, de metas (...). (Vigilar y castigar 218)

En el caso de La rumba, el clero y la iglesia forman parte de esa modalidad moderna para ejercer el poder disciplinario que busca, por un lado, presentar como natural un orden artificial (en este caso los escaños sociales ocupados por la otredad racial económica y cultural de la ciudad) y, por otro, “enderezar conductas” (Foucault, Vigilar y castigar 75); es decir normalizar desviaciones que quebranten el orden establecido. El aparato de justicia moderno necesitaba además de un órgano de vigilancia constante (cuerpo policial y/o sistema penitenciario) (Foucault, Vigilar y castigar 101); ya que Remedios no termina en la cárcel de Belén, su castigo lo vivirá en su barrio de origen y el cura del pueblo estará a cargo de su vigilancia. La novela cierra con este significativo diálogo: “-Adiós, y cuidado 
con volver... - Ah, señor Borbolla, nunca, nunca he de querer ya parecerme a las rotas. ¡Dios lo haga!...” (133).

A primera vista pudiese parecer que Ángel de Campo castiga con este final la actitud de su protagonista; sin embargo, sucede lo contrario. Con este cierre De Campo denuncia, aunque de forma velada, el destino inexorable al que se mantenía sometida a la otredad citadina en la Ciudad de México de finales del siglo XIX. ${ }^{114}$ Tal como propone Manuel Prendes Guardiola, Micrós sentía un interés particular por personajes de extracción popular, no obstante, no los utiliza como ejemplos decorativos de "mexicanidad" (como sí podría atribuírsele a algunos cuadros de costumbres de la época) sino como seres condenados a una realidad proscrita por la burguesía que regía la marcha de la sociedad (150). De Campo ha sido ubicado en la generación que la historiografía literaria bautizó como "promoción realista mexicana". Estos escritores comparten, además del uso del realismo y/o naturalismo europeo, la voluntad de definir la nación en términos positivistas. Pese a esta filiación, Micrós rompe filas con La rumba y diciendo sin decir deconstruye y pone en evidencia las fallas del discurso criminológico sobre el que se asentó la organización social urbana durante el porfiriato.

\section{El conventillo: ciudad e inmigración}

En 1917 el argentino Luis Pascarella publicó El conventillo (Costumbres bonaerenses); novela que narra la vida de los habitantes de una casa de inquilinato de

\footnotetext{
${ }^{114}$ De Campo quedó huérfano de padre a los cuatro años y su madre murió durante su primer año de carrera. Por estas razones, tuvo que dejar la universidad para ocuparse de sus tres hermanos menores. A pesar de su vocación literaria, trabajó la mayor parte de su vida como periodista, profesor de literatura y como funcionario de la Secretaría de Hacienda durante el porfiriato. Sus responsabilidades familiares, así como su siempre inestable situación económica hizo que sus ingresos estuviesen atados, al igual que los de Federico Gamboa de quien fue compañero de escuela, al mismo sistema que critica. Se entiende entonces por qué la denuncia presente en La rumba no es abierta, sino que debe leerse entre líneas.
} 
cuarenta habitaciones localizada en la ciudad de Buenos Aires a principios del siglo XX. A diferencia del resto de las novelas que he abordado en este estudio, El conventillo no entra dentro de la categoría de portrait study propuesta por Blanche Housman Gelfant. Se trata, en cambio, de un ecological novel, categoría de novela urbana que la autora estadounidense define de la siguiente manera: "The ecological novel differs from the portrait study by having as its protagonist not a single person but a spatial unit (...) Interest thus focuses upon the social relationships and manners within a close group, although one figure may come to prominence (...) The title of the ecological novel often specifies the spatial unit" (12-13).

La unidad espacial seleccionada por Pascarella resulta evidente desde el título de la obra y la figura destacada es Ana María Capizzi, una italiana recién llegada a Buenos Aires para rencontrarse con Francisco, su esposo, quien ya vivía en Argentina y en la casa de vecindad al momento de su llegada. También resalta de manera particular la figura de Pascuale Piselli, ${ }^{115}$ el administrador del conventillo. La verdad es que todos los moradores de la casa de inquilinato aparecen en el texto en todo momento con mayor o menor protagonismo y/o agencia sobre los acontecimientos que suceden; casi como si fuesen una masa indivisible e irremediablemente atada al espacio en el que cohabitan. Los primeros ocho capítulos están dedicados a la descripción de cada uno de ellos, los conocemos uno a uno mientras don Pascuale les cobra la renta mensual. No obstante, y por razones tanto temáticas como de espacio, me concentraré en la figura de Ana María y de Pascuale.

\footnotetext{
${ }^{115}$ En la novela, la grafía del nombre de este personaje oscila entre Pascuale y Pasquale. Para evitar confusiones, solo utilizo la primera.
} 
La novela inicia con la descripción del conventillo, sus habitantes y su administrador. La imagen es desoladora, pues las condiciones de vida en la casa de vecindad son, en el mejor de los casos, deprimentes y, en el peor de los casos, insalubres. La voz narrativa indica:

Las dos primeras habitaciones, números 1 y 2 denominadas salas, tenían una pequeña ventana de reja a la calle, la mayor parte, sólo la puerta, y algunas, como la de Francisco, tenían puerta y ventanilla que comunicaban con el patio. Y el patio carcomido, resbaladizo, pegajoso, teóricamente dividido en tantos cuadros como cuartos, desaparecía casi por completo bajo el amontonamiento de cajones ennegrecidos (...) y cuanto trasto y cachivache de todo pelaje puede imaginarse.

Y por sobre los montones de trastos, en sogas tendidas de cuarto a cuarto, flameando a manera de bandera y gallardetes mil prendas de vestir de todas las formas y colores, mezclaban su tufo de lavadero al vaho de pocilga que brotaba de las habitaciones. Y resbalando sobre aquel manantial de mugre, moviéndose con embarazo entre la apilada trastería, respirando aquella atmosfera de ergástula, cuarenta familias de idioma, costumbres y modalidades diferentes, desarraigadas del centro, del norte y del mediodía de Europa, habíanse reunido allí impulsadas por un solo sentimiento común: la esperanza de la lucha con provecho, la fortuna rápida y fácil que para la mayoría es la esencia misma de la palabra América. (11-12)

En estas paupérrimas condiciones viven los personajes de la novela de Pascarella, personas humildes pertenecientes a la clase trabajadora: zapateros, costureras, modistas, 
carpinteros, pintores, maestros de escuela, etc., quienes no pueden costear otro tipo de vivienda. En pocas palabras, se trata de la otredad citadina. A diferencia de los habitantes de La Rumba en la obra de De Campo, los moradores del conventillo de Pascarella no son negros, indios, mestizos o pardos sino inmigrantes, italianos casi todos y españoles algunos (resaltan un gallego y un andaluz). En la casa de vecindad tan solo vive una argentina, la inquilina más antigua, conocida con el mote de la Paisa. No sorprende que así sea pues la otredad citadina bonaerense tuvo un perfil bastante diferente a la de otras ciudades latinoamericanas.

La constitución argentina de 1853 instituyó una política de puertas abiertas a la inmigración europea auspiciada por políticos como Juan Bautista Alberdi que, como comenté en el capítulo II, consideraban que gobernar equivalía a poblar al país (17). ${ }^{116}$ Como resultado, Argentina se convirtió en el segundo país del continente que recibió más inmigrantes a lo largo del siglo XIX: ${ }^{117}$ entre 1874 y 1914 acogió alrededor de seis millones extranjeros (la mayoría provenientes de Italia) (Torres-Pou, “Ciudad e inmigración” 279). Es cierto que esta política migratoria pretendía repoblar al país de manera acelerada luego de la merma poblacional ocasionada por las guerras de independencia y las guerras civiles (Romero, "La ciudad latinoamericana..." 301); no obstante, también respondía a las teorías eugenésicas de la época que, como se sabe, consideraban a los caucásicos como una raza biológica y moralmente superior. Por lo tanto, esta iniciativa constituía una estrategia de

\footnotetext{
${ }^{116}$ En la máxima de Alberdi hay ecos de la postura de los conquistadores y los cronistas de indias. Por ejemplo, Francisco López de Gómara afirmaba: "Quien no poblare no hará buena conquista, y no conquistando, no se convertirá la gente; así que la máxima del conquistador ha de ser poblar" (67). En la época de López de Gómara se poblaba para cristianizar; en la de Alberdi para civilizar.

${ }^{117}$ El primero fue Estados Unidos que recibió 27 millones de inmigrantes (aprox.).
} 
blanqueamiento de la población. De allí que la política migratoria no se enfocara en cualquier tipo de inmigración sino en la europea en específico. Pese a esto, en las postrimerías del siglo XIX la valoración de la inmigración en general y del inmigrante italiano en particular por parte de la sociedad argentina distaba mucho de ser positiva. ${ }^{118}$

En 1884, Juan Antonio Argerich publicó su polémica novela ¿Inocentes o culpables?, texto que antecede desde el punto de vista temático a El conventillo. ${ }^{119}$ Según el propio Argerich, su novela es producto de "una vibración de verdadero patriotismo, inspirada por nobles aspiraciones del presente que tienden á prever dolores del futuro" (I). Por tal razón se dedica en su texto al estudio de "una familia de inmigrantes italianos-y los resultados á que llego no son escepciones, sino casos generales" (II). Para el momento de publicación de ¿Inocentes o culpables? la política migratoria argentina seguía siendo la misma que a mediados del siglo XIX; no obstante, Argerich se opone a ella en el prólogo de su obra ya que, si bien el incremento de población seguía siendo crucial para el país, a su modo de ver los censos no estaban arrojando los números deseados. Tales argumentos son cuestionables ya que el crecimiento poblacional en Argentina difícilmente pudo haberse estacionado, como esgrime Argerich, con la entrada al país de casi siete millones de personas. La postura

\footnotetext{
${ }_{118}$ Alberdi especifica que la inmigración debe provenir de la Europa civilizada y no de la Europa atrasada (17-18). La primera se asocia con el norte de Europa y Francia y la segunda con el sur de Europa y España. De allí la desilusión de los argentinos con la llegada masiva de los italianos ya que esta inmigración entraba en la categoría no deseada. A ojos de Álvaro Salvador Jofre, la máxima de Alberdi estaba además condenada al fracaso pues no había tierras que repoblar ya que el sistema oligárquico de posesión de tierras no desapareció con el advenimiento de la república. La población que pedía Alberdi no era necesaria en Buenos Aires sino en las provincias; sin embargo, solo se propició el desarrollo de la ciudad y, por esta razón, los inmigrantes se aglomeraron en la capital que aglutinaba la escasa e incipiente industria del país (73).

${ }^{119}$ Ambas son novelas de ciudad y, a la vez, novelas de inmigración. Por su parte, Joan Torres-Pou propone que El conventillo está inspirado en otro ecological novel decimonónico publicado en 1890 y titulado $O$ cortiço, escrito por el brasilero Aluísio Azevedo (1857-1913). Azevedo vivió en Buenos Aires los últimos años de su vida y es considerado como el máximo novelador de la ciudad latinoamericana en el siglo XIX (“Ciudad e inmigración" 265).
} 
del autor de ¿Inocentes o culpables? responde más bien a la búsqueda de un nuevo chivo expiatorio al cual achacarle la responsabilidad de los obstáculos para civilizar y modernizar tanto a Buenos Aires como a Argentina. En este sentido, Diegos Armus señala que la estrategia pasó de "gobernar es poblar" a "gobernar es sanear" (140).

La inmigración europea sí cambió el perfil racial de los argentinos y, en particular, el de los bonaerenses. El porcentaje de negros, indios y/o personas de color era mucho más bajo en la Buenos Aires finisecular que en otras capitales latinoamericanas. ${ }^{120} \mathrm{Si}$, la población blanca era en efecto más civilizada, como pretendía la ciencia del momento, ¿por qué a comienzos del siglo XX seguían teniendo los argentinos los mismos problemas sociales/urbanos que otros países latinoamericanos? Para dar respuesta a esta pregunta, se hizo uso de nuevas pseudociencias, como la ya mencionada frenología, que explicaran la situación a nivel biológico ya que incluso dentro de los caucásicos había rezagos fisiológicos indeseables. Argerich entonces se pregunta con respecto a los italianos: “¿Cómo, pues, de padres mal conformados y de frente deprimida, puede surgir una generación inteligente y apta para la libertad? Creo que la descendencia de esta inmigración

\footnotetext{
${ }^{120}$ Dentro de este contexto resulta de interés señalar que, si bien es cierto que la inmigración europea cambió el perfil racial de la Buenos Aires finisecular, sobre todo si se le compara con la población de otras capitales latinoamericanas; no es verdad que los negros o las personas de color hayan desaparecido totalmente en el siglo XIX como ha querido hacer ver la historiografía tradicional argentina. Críticos como Miriam Gomes identifican estrategias retóricas de invisibilización de la población afroargentina desde mediados del siglo XIX. Gomes afirma que los censos de la época fueron falseados con notoria frecuencia y que provincias que a principios del siglo XIX tenían un $50 \%$ de población negra aparecen en apenas unas pocas décadas decimadas hasta llegar a un supuesto $1,8 \%$ de población $(\mathrm{s} / \mathrm{p})$. Resulta significativo entonces que no aparezcan personajes negros ni de color en ninguna de las dos novelas argentinas abordadas en este estudio (La gran aldea y El conventillo). Gomes plantea también que, en contraposición a esta voluntad de invisibilización institucional, las comunidades afroargentinas desarrollaron diferentes estrategias de resistencia entre las que resaltan la asociación y fundación de formas organizacionales $(\mathrm{s} / \mathrm{p})$. El Shimmy Club, por nombrar un ejemplo, fue una asociación de afroporteños fundada en 1882 que organizaba fiestas y bailes para la población negra de Buenos Aires. En 1978 cerró sus puertas y en el 2015 fue demolida la Casa Suiza, edificación que alquiló el club para sus eventos por casi 60 años. La Casa Suiza era uno de los últimos baluartes materiales de los afroargentinos en Buenos Aires.
} 
inferior no es una raza fuerte para la lucha, ni dará jamás el hombre que necesita el país" (IV). Si no se podía diferenciar la población "superior" de la "inferior" a través del color de la piel se utilizarían entonces nuevos parámetros físicos como el tamaño de la frente y del cráneo. Así fue como la cuestión racial devino en Argentina en la cuestión inmigratoria (Armus 140). Estos discursos excluyentes no solo cuestionaban el potencial biológico de los inmigrantes sino también el moral.

La sed de ganar dinero era, a ojos de la intelectualidad finisecular argentina, un rasgo innato en los inmigrantes italianos. ${ }^{121}$ Esta característica se asociaba a la avaricia desmesurada y se concebía como un defecto moral hereditario capaz de degenerar a la sociedad bonaerense. Estas ansias de riquezas de los italianos es el motivo que estructura la historia y que condiciona las relaciones interpersonales de los personajes tanto en ¿Inocentes o culpables? como en El conventillo. Por ejemplo, de José Dagiore protagonista, junto a su esposa Dorotea, del texto de Argerich, dice la voz narrativa:

No ganaba nada, pero sin embargo, ahorraba peso sobre peso, -aberración económica que solo puede explicar un inmigrante de la bella Italia $(\ldots)^{122}$ A las once, hora del descanso, se sentaba apartado á comer su gran pan italiano y pensaba febricientemente en el dinero, aislándose en su pensamiento para espandirse en monólogos mentales: mucho dinero, dinero

\footnotetext{
${ }^{121}$ Paola Cortés-Rocca propone que "la utopía de la inmigración funciona de manera doble -colocando un ideal tanto para los inmigrantes, como para la tierra que los recibe" (179). Ese sueño al que aspiraban los italianos que llegaban a Buenos Aires era, por supuesto, mejorar sus condiciones de vida; no obstante, este ideal es demonizado como rasgo enfermizo por los detractores de la inmigración italiana en Argentina.

${ }^{122}$ El uso de la palabra aberración es significativo. El diccionario de la Real Academia Española define el vocablo como "acto o conducta depravados, perversos, o que se apartan de lo aceptado como lícito". Esta conceptualización negativa del ahorro condena a quienes lo practican a estar fuera de la norma y los liga a conductas criminales.
} 
y nada más (...) era la animalidad descarnada del avaro. Quería ahorrar y

así lo hacía, -sobre su hambre, sobre su sed, á despecho de la salud y de la

higiene de su cuerpo: ahorraba por ahorrar ó tal vez por hábito heredado

$(\ldots)(2-3)$

El trabajo y el ahorro como método de superación personal, rasgos en teoría inofensivos e incluso positivos, son concebidos en esta cita y en la obra de Argerich como defectos fatales de carácter casi enfermizo (ver el uso de la palabra febriciente) ${ }^{123} \mathrm{y}$, además, hereditario. Esta postura de los inmigrantes hacia el trabajo y el dinero resultaba amenazadora para la élite bonaerenses, en especial para los descendientes de la antigua clase patricia colonial (de la cual descendía el propio Argerich) que aún conservaban resabios de los conceptos hispanos de hidalguía y pureza de sangre. Este último rasgo no solo se asociaba a las mezclas raciales sino también a los trabajos considerados inferiores, como el comercio o la agricultura, casi siempre realizados por la otredad racial, social y cultural de la ciudad y/o el país. Ahorrar y amasar fortuna significaba la posibilidad de movilidad social de las clases inferiores, cuestión que las élites no estaban dispuestas a aceptar pues podía poner en entredicho su posición social. ${ }^{124}$

${ }^{123}$ Febriciente es un vocablo de uso común en los países del Cono Sur; no obstante, la Real Academia Española no la ha aceptado y utiliza en su lugar adjetivos como febril o febricitante para hacer referencia a alguien que tiene fiebre o calentura.

${ }^{124}$ En enero de 1885 el crítico literario del momento, Martín García Mérou, publica una reseña de la novela de Argerich en donde la critica con dureza. Una de las cosas que le reprocha García Mérou al autor de ¿Inocentes o culpables? es el uso del género naturalista al cual califica de "género falso y violento" (s/p). Otro asunto que García Mérou considera inaceptable, y que a mí me interesa dentro del contexto de este estudio, es la inverosimilitud de los personajes:

Un hombre avaro, ignorante, que principia limpiando botas y, céntimo sobre céntimo, amontona una miserable cantidad, no se resigna tan fácilmente a los caprichos de una mujer a quien no quiere, hasta el punto de permitirle gastos e instalaciones superiores a su esfera. Del mismo modo, una mujer de la clase y de la cuna de Dorotea, no asiste a los recibos semanales de un Ministro de Estado con tanta facilidad. No es porque la echemos de aristocráticas, aunque en realidad lo seamos, ni por que entre nosotros las clases estén 
Por su parte, el narrador de El conventillo señala acerca de los inquilinos y el tema del dinero: "La salud, la estrechez, las privaciones, las satisfacciones de otras necesidades que no fueran las más indispensables, desaparecían ante la idea obsesionante de ganar y ganar plata y más plata" (80). A primera vista pareciera que la postura de Argerich y Pascarella es la misma pues los inmigrantes de ambos textos viven en condiciones deplorables, llegando a los extremos de supeditar su salud y alimentación (y las de sus familiares) a la posibilidad de tener más dinero. No obstante, Pascarella, de quien poco se sabe, pero cuyo apellido permite suponer una ascendencia italiana, poco a poco y de manera casi imperceptible socava los argumentos con los que Argerich construye su novela y con los que justifica una postura abiertamente xenófoba en pro del nacionalismo argentino.

La primera idea que Pascarella desmiente es la de que los inmigrantes italianos viven en suciedad y sufriendo estrecheces porque todos, como rasgo atávico, son ambiciosos y avaros. Los responsables de la deprimente arquitectura y mantenimiento del conventillo de Pascarella no son sus habitantes; sino don Pascuale Piselli, encargado de construirlo y administrarlo. Don Pascuale, italiano al igual que sus inquilinos, recibe el apodo de "el rey de los conventillos" (14) pues en cualquier espacio baldío de Buenos Aires levantaba una casa de vecindad. La voz narrativa señala: "su repetida aparición (la de Piselli) en un lugar determinado constituía un signo inequívoco del seguro y rápido progreso (...) era el jalón inconfundible que anunciaba el monstruoso crecimiento de la gran ciudad" (15). El supuesto progreso al que se hace referencia en esta cita está lejos de la ampulosidad

divididos por abismos infranqueables; pero, así y todo, hay diferencias que nada salva (...) $(\mathrm{s} / \mathrm{p})$

Es decir, a ojos de García Mérou, José Dagiore y Dorotea no son personajes creíbles pues su movilidad social no es verosímil dentro de la sociedad bonaerense finisecular. 
moderna de las reformas arquitectónicas de estilo francés que se realizaron en ciertas zonas

de Buenos Aires a partir de las últimas dos décadas del siglo XIX.

Con El conventillo Pascarella visibiliza un lado del crecimiento moderno que tanto los políticos de turno como otros escritores de la época omitieron. Y es que, al igual que los prostíbulos, las casas de inquilinato fueron símbolo de la modernidad, del crecimiento urbano desmesurado y, en el caso de Argentina, de la numerosa inmigración italiana. Alejandra K. Carballo alega que entre 1887 y 1917 del 10\% al 25\% de la población bonaerense vivía en estas casas de inquilinato de dudosa higiene (83). Don Pascuale especifica con respecto a sus conventillos: "un amasijo de barro en plena calle, cuatro tablas viejas, una mano de cal y ce n'é troppo per questa gentaglia" (15). ${ }^{125}$ La voz narrativa, por su parte, los denomina "parodias de casa" (15). La supuesta gentuza lidia con semejantes condiciones pues, a pesar de las estrecheces y de trabajar de sol a sol, están condenados a habitar dicho espacio pues viven oprimidos por un sistema que no les permite ni costear otra cosa ni salir del entorno urbano que les fue asignado de manera tácita debido a su origen y clase social.

\footnotetext{
${ }^{125}$ Tanto la cursiva como la frase en italiano aparece en el texto original. Pascarella incluye múltiples frases e incluso, en algunas ocasiones, largos párrafos en italiano; sin embargo, no ofrece ningún tipo de glosario o traducción. Blance Housman Gelfant indica que "The form of the city novel has important implications for the language as well as the setting. Since the ecological form limits the settings to a circumscribed and usually peculiar area, it may use this area's characteristic speech as a means of creating character and scene" (15). Si bien esto no deja de ser cierto, el uso del italiano en una obra literaria resulta atípico para la época de publicación de El conventillo. Para finales del siglo XIX y principios del XX era común ver el uso del francés (sin traducción) en obras latinoamericanas. También se publicaban en los periódicos y revistas literarias del momento obras de autores franceses en su idioma original. No obstante, es importante tomar en cuenta que el francés era la lengua del país que fungía como modelo civilizador; por lo tanto, también era la lengua de la modernidad, de la cultura y del arte. Las personas de las élites (sobre todo las mujeres), que al fin y al cabo eran los consumidores tanto de la literatura como de la prensa periódica, hablaban y/o leían en francés. El italiano, por el contrario, era la lengua de los inmigrantes considerados inferiores por lo que no se solía incluir en publicaciones de ningún tipo. Por otro lado, muchos de estos inmigrantes eran analfabetas. Desconozco que porcentaje de la población argentina podía leer y entender italiano para la fecha de publicación de $E l$ conventillo.
} 
En Buenos Aires, los conventillos formaban parte de esa "ciudad bárbara" a la que tanto temía y despreciaba el ya mencionado intendente de Santiago de Chile, Benjamín Vicuña Mackenna, quien planteaba lo siguiente:

Es necesario tomar una medida seria para poder asegurar la salubridad i vigilancia de esos lugares (...) la única que puede aportarse es obligar a sus propietarios que son todas pudientes, que cierren completamente sus propiedades con una muralla de adobón sólido o de adobe que tenga lo menos dos metros de altura; que, de trecho en trecho, se coloquen sólidas puertas que deben cerrarse a cierta hora de la noche. (32)

Como se desprende de esta cita, la otredad urbana finisecular, que en el caso de Buenos Aires eran los inmigrantes, eran considerados criminales enfermos porque vivían en conventillos. Adriana Bergero señala que, en el caso porteño, esta narrativa partía del Departamento de Salud Pública de la ciudad: "The tenement population was stigmatized by such narratives and subjected to relentless intervention, inspection, and surveillance" (91). Estas ideas justificaban que en los conventillos se viviese en condiciones carcelarias a pesar de que sus habitantes no hubiesen infringido la ley; en algún momento irremediablemente lo harían. Esta insistencia en criminalizar a ciertos grupos de la población responde a estrategias de control de aquellos que se encontraban en el poder para salvaguardar su posición. Ángel Rama señala al respecto: “Es propio del poder que necesite un extraordinario esfuerzo de ideologización para legitimarse; cuando se resquebrajen las máscaras religiosas construirá opulentas ideologías sustitutivas" (5).

Si bien es cierto que el conventillo de don Pascuale no tiene las murallas monitoreadas que propone Vicuña Mackenna, es descrito en diferentes ocasiones en términos carcelarios 
por la voz narrativa que lo califica de ergástula con cuartos que "más que habitaciones de seres humanos y libres parecían inmundos establos o celdas expiatorias de endurecidos criminales" (11). ${ }^{126}$ La supuesta ambición de los italianos los condiciona por un lado a vivir en estos deplorables espacios y, por otro, a convertirse en criminales. ${ }^{127}$ Don Pascuale, por ejemplo, incumple los requisitos mínimos de higiene en sus conventillos y evita las posibles multas o sanciones a través de sobornos a los funcionarios de la municipalidad. ${ }^{128}$ Ana María, por su parte, llega al infanticidio.

Cuando Ana María arriba a Buenos Aires, su esposo le aclara que "en América las mujeres no tienen que ir a misa. Hay que ayudar al marido. Hay que trabajar. Mejor era levantarse temprano para lavar la ropa de los paisanos y buscarle a Rosina una casa donde aprendiese el oficio" (78). Si bien es cierto que la mujer decimonónica debía cumplir el papel de madre y esposa, no era atípico que las mujeres de clases bajas trabajaran. Su

\footnotetext{
${ }^{126}$ En la antigua Roma, una ergástula era una cárcel de esclavos. El uso de esta palabra revela las condiciones de talante carcelario del conventillo, así como la situación de los inquilinos quienes eran esclavos de su posición social y económica. Esta cita también revela la valoración de los inmigrantes como seres inferiores, cercanos a los animales. Como argumenté con anterioridad, la criminología positivista consideraba que los delincuentes tenían un estado evolutivo más atrasado que los hombres que se comportaban dentro de la ley. Es decir, eran más cercanos a los animales que al hombre civilizado y, por esta razón, se justificaba que viviesen y fuesen tratados como tales. Ana María, por ejemplo, antes de ser aceptada como ama de leche por los Gómez Salustio, es sometida, delante de toda la familia, al mismo examen físico que sufrían las vacas lecheras en la exposición de la Sociedad Rural (asociación, fundada en 1866, de grandes propietarios de tierras dedicados a la agricultura y/o la ganadería en Argentina) (146).

${ }^{127}$ En La rumba de Ángel de Campo también aparece esta comparación de los ambientes subalternos citadinos con las prisiones, pero de manera inversa: se afirma que la cárcel de Belén es igual a cualquier suburbio. La voz narrativa dice lo siguiente acerca del patio de los presos:

Unos fumaban recargados a las columnas, otros acurrucados se calentaban en el sol, a cuyo calor veíanse expuestos y colgados de los barandales del corredor, sarapes de brillantes colores, pantalones mojados, sábanas extendidas, petates húmedos y enlodados guaraches. Diríase que era el pueblo reunido para alguna fiesta de plazuela (...) la rueda de un torno zumbaba tras un tabique, golpeaba un martillo en el taller de carpintería y se desbordaba del estanque un agua bulliciosa y turbia (...) (102)
}

${ }^{128}$ En estas prácticas de soborno cotidiano hay implícita una denuncia de la incompetencia de las instituciones y burocracia que se desarrollaron a partir de la expansión de las ciudades. 
situación, sin embargo, y como ya he argumentado en el capítulo III era en extremo precaria pues solo había un puñado de oficios a los que les era permitido dedicarse. Ana María, desencantada de la vida en Buenos Aires, se convierte en lavandera y comienza a administrar de manera minuciosa y estricta la contabilidad del hogar. Su gran deseo era tener suficiente dinero para poder regresar a Italia, razón por la cual reduce su alimentación y la de sus familiares a pan y mate.

Los planes de la protagonista se ven inicialmente frustrados porque queda embarazada. Un nuevo hijo tan solo significaba para Ana María una boca más que alimentar cuestión que la alejaría de su objetivo final. Sin embargo, y de manera sorpresiva, la maternidad le ofrece a la italiana la posibilidad de una retribución económica ya que don Pascuale le presenta la oportunidad de trabajar como ama de leche en casa de los Gómez Salustio que buscaban "alguna gringa fuerte y recién parida" (102). ${ }^{129}$ El sueldo pautado produce una nueva preocupación para Ana María que: "exploraba con mirada febril el vientre de cada mujer que cruzaba a su puerta, temerosa de encontrar competidora. ¡Cien nacionales! ¡Cien nacionales por mes! La frase adquiría tonalidades metálicas y un estremecimiento desconocido sacudía toda su red nerviosa" (152). De esta cita se desprende que la relación de Ana María con el dinero deviene en enfermedad mental que culmina en homicidio.

Ana María da a luz; pero los Gómez Salustio le exigen dedicación exclusiva a su bebé. Por esta razón la italiana debe, a su vez, dejar a su hijo a cargo de otra ama de leche, una gallega que vivía por La Boca. ${ }^{130}$ Este requerimiento significaba, por supuesto, la merma

\footnotetext{
${ }^{129}$ La palabra gringo(a) era utilizada en Argentina a finales del siglo XIX para referirse a cualquier extranjero y no solo a los estadounidenses.

${ }^{130}$ A principios del siglo XIX el área de La Boca (bautizada con este nombre por encontrarse cerca de la desembocadura del río Matanza-Riachuelo) estaba casi deshabitada. Debido a su cercanía a la zona de entrada
} 
de sus ingresos mensuales y el retraso de su regreso a Italia. Mientras rumiaba su situación una noche, Ana María cae en un sueño soporífico:

Soñó que sentía un malestar originado por algo que le había salido en el costado izquierdo: un burujón que hacía esfuerzos para perforarle el vacío. La sensación dolorosa medio la desveló y aun en ese estado continuó sintiendo que algo se estremecía, palpitaba, se agitaba convulsivamente debajo de su cuerpo (...)

Cuando al amanecer se despertó, abrió los ojos e intentó apartar el objeto que tenía debajo del costado, un estremecimiento paralizó todas sus fibras: había oprimido la cabecita de su hijo.

Horas después, el médico de policía comprobó que la muerte del chico se produjo por asfixia. (152-153)

El fallecimiento del bebé es catalogado como un accidente y Ana María no es llevada a un juzgado por ello; no obstante, en la narración se deja ver de manera evidente que el incidente fue causado por la relación obsesiva de la italiana con el dinero. Con todo, Pascarella, no culpa a su personaje sino a su entorno.

Al igual que ¿Inocentes o culpables?, El conventillo está construido desde una perspectiva naturalista/determinista. A pesar de esta similitud, ambas novelas difieren pues Argerich se afinca en el aspecto biológico para explicar la degeneración de sus protagonistas mientras que Pascarella pone ese peso en el entorno urbano. En el caso de

de los barcos, La Boca comenzó a poblarse a mediados del siglo XIX por inmigrantes (casi todos genoveses). Para finales del siglo, La Boca ya tenía una población cercana a 40.000 habitantes distribuida en numerosos conventillos construidos a partir de chapas de metal acanaladas pintadas de múltiples colores. Hoy en día el barrio es una atracción turística de Buenos Aires; no obstante, a comienzos del siglo XX era tan solo uno de los tantos indeseables suburbios de la capital argentina. 
Ana María y de su suegra, se especifica que desde su llegada a Buenos Aires "sentían los efectos del nuevo medio” (75). Al inicio, Ana María no tenía ningún interés por el dinero sino todo lo contrario, se dedicaba a cuestiones espirituales, iba a misa y visitaba todas las iglesias de Buenos Aires. Al ir a la Catedral por primera vez "oró con fervor y al salir juró volver todos los días. Creyó que por fin había encontrado algo que hacer y regresó más erguida con los ojos brillantes, ansiando comunicarle la noticia a su suegra" (77).

Francisco se indigna ante las andanzas de su esposa, la golpea y le exige que contribuya a ganar dinero mientras Ana María pide a gritos volver a Italia. Luego de este episodio la actitud de la protagonista cambia y la voz narrativa concluye: "el conventillo había producido su obra, la había conquistado" (80). A partir de este momento Ana María no hace más que pensar en dinero; no obstante, queda claro que esta obsesión no es natural en la italiana, sino que es impuesta por el entorno urbano. El propio administrador del conventillo así lo afirma: “-Paisanos son éstos, replicó rápidamente don Pascuale, dándose una fuerte palmada en el bolsillo del pantalón. -Estamos en América y en América no hay otros paisanos" (14).

Luego de la muerte de su hijo, Ana María transfiere su instinto maternal al bebé de los Gómez Salustio que tiene a su cuidado, al cual comienza a confundir con su propio vástago llamándolo de manera repetitiva "mi hijo" $(247,251)$ o "mi nene" $(253,254,255)$. Cuando el niño cumple un año de edad, el médico familiar exige comenzar el destete razón por la que se le prohíbe a la protagonista acercarse al pequeño. Esa primera noche de separación Ana María tiene un sueño similar al de la noche en que accidentalmente asfixió a su hijo. Ambos bebés se entremezclan en uno: 
De pronto, pareciole que una cosa húmeda y fría, con el frío de la muerte se interpuso entre el jergón y su costado izquierdo (...) aquel brujón, convertido ahora en bola de fuego, le taladraba el vacío. ¡Ah! Era la cabecita del nene, de "su nene", del hijo que había mamado durante un año la leche de sus pechos. ¡Por Dios, por Dios que lo saquen, que lo salven! (...) Entonces se despertó bañada en sudor (...) sus dedos oprimieron el pañuelo con el dinero que se había apelotonado e impedía la circulación de la sangre. $\mathrm{Al}$ retirarlo, sintió un gran alivio. ¡Ah! ¡Era la plata, la inmunda plata! Que se la lleven, que se la lleven, en cambio de su nene. (254)

De aquí en adelante, Ana María gasta todo el dinero ahorrado sobornando a diferentes empleados de la casa de los Gómez Salustio para poder tener acceso al niño, quien, en el último encuentro, y debido al distanciamiento, no la reconoce. La italiana, despechada, se deja caer del coche donde viajaba el pequeño con su nueva gobernanta y es atropellada por un carro.

La historia de Ana María desmiente la idea de la avaricia como rasgo atávico de los inmigrantes pues la italiana no solo no adquiere la obsesión por el dinero hasta que llega a Argentina, sino que, además, la deja de lado en la búsqueda de "su nene". El conventillo y la ciudad de Buenos Aires y sus dinámicas son los agentes degeneradores responsables de la relación enfermiza de los personajes de la novela con el dinero y de las ansias de riqueza fácil y rápida de los habitantes de la capital. En este sentido, El conventillo empalma también con otras novelas de ciudad argentinas de la época, como La bolsa (1890) de José María Miró (mejor conocido con el seudónimo de Julián Martel) o Quilito (1891) de Carlos María Ocantos, que abordan el mismo tema, pero en personajes pertenecientes a la 
burguesía y a la antigua aristocracia. Sin embargo, la perspectiva de Pascarella resulta novedosa pues se enfoca en espacios citadinos y habitantes invisibilizados por el discurso grandilocuente de la modernidad. Y es que la obsesión por el dinero de las clases altas no puede compararse al de las clases bajas, pues las primeras buscan conservar (o aparentar que conservan) su posición social a través de un tren de vida de lujos incalculables mientras que las segundas simplemente pretenden sobrevivir y alcanzar en algún momento una situación económica estable. La propia Ana María considera el dinero como "el único instrumento capaz de concluir con tantas humillaciones y penurias" (127). Al igual que en el caso de Remedios, la protagonista de La Rumba de Ángel de Campo, la conducta de Ana María en particular (y la del resto del inmigrante es general) es considerada delictiva no tanto por la muerte del bebé sino por aspirar a cambiar su condición social.

Juan Antonio Argerich se queja de que las familias inmigrantes antes vivían "en el cuarto del conventillo, la subsistencia era barata por lo sóbria, no pensaba en trajes; pero después, al subir de rango, el crecimiento se detiene al encontrar dificultades para satisfacer las exigencias de una vida más múltiple" (IV). Es decir, se lamenta de que los inmigrantes no se circunscriban a los conventillos, el espacio que les fue asignado como parte de la otredad citadina. Así se crea la retórica de que las ansias de mejora social de los italianos responden a la avaricia y a un materialismo estéril (ya definido por José Enrique Rodó en Ariel como un rasgo de la barbarie urbana) y no a la voluntad de salir de un medio embrutecedor. El deseo de alcanzar el bienestar económico se demoniza y se perfila como un defecto que estereotipa de manera negativa a estos seres subalternos y que, a la vez, disfraza el miedo de las clases altas a perder su posición hegemónica. El uso del discurso de la criminología positivista, que identificaba la inclinación al crimen siempre en factores 
biológicos y nunca sociales, no solo justificaba las condiciones de vida deplorables de los seres subalternos, sino que también absolvía a las clases en el poder de responsabilizarse por las condiciones embrutecedoras en las que los mantenían, las cuales podían o no, llevarlos a actos delictivos desesperados. Con su novela, Pascarella pone en evidencia estas incongruencias.

En El conventillo Ana María es homicida y, a la vez, víctima. La muerte del bebé de la italiana viene determinada por sus deplorables condiciones de vida; pero también por la posición de los Gómez Salustio que, aunque no requieren de manera explícita el asesinato del niño, exigen que Ana María no lo alimente para dedicarse de forma exclusiva a su vástago. Aunque resulta evidente que un niño recién nacido no puede sobrevivir sin los cuidados de la madre (o de algún otro adulto), los Gómez Salustio no se ocupan ni se preocupan del destino de ese bebé ni de las posibilidades económicas de Ana María de ponerlo a cargo de otra persona. Es decir, para que el niño argentino sobreviva el italiano debe perecer. La leche de Ana María robustece al nene de los Gómez Salustio al igual que la fuerza de trabajo de los inmigrantes a la economía argentina; no obstante, son seres de los que se hace uso, pero a los que no se pretende incluir en el acervo nacional. En este sentido resulta significativo que Pascarella haya incluido en el texto los modismos y forma de hablar de los "tanos" 131 que con frecuencia mezclaban el español con el italiano (o con otras lenguas locales de Italia).

El rol de madre, adjudicado a toda mujer decimonónica, se ve truncado en el caso de Ana María. Alejandra Karina Carballo ve en este hecho, así como en la infertilidad de

\footnotetext{
${ }^{131}$ Coloquialismo con el que se denomina, aún hoy en día, a los inmigrantes italianos y a sus descendientes en Argentina y Uruguay.
} 
otras moradoras italianas del conventillo, ${ }^{132}$ una especie de eugenesia literaria que por un lado esteriliza a los personajes femeninos extranjeros y por otro demuestra la desconfianza de Pascarella en la capacidad reproductiva regeneradora de los inmigrantes italianos (96). Es cierto que ninguno de los personajes de El conventillo recibe un tratamiento positivo por parte del narrador; sin embargo, y a mi modo de ver, este mosaico humano de seres fracasados, alcohólicos, corruptos, materialistas e incluso violentos muestra la calidad y el tipo de personas que entornos urbanos como los conventillos pueden producir. Luis Pascarella era partidario del amor "al trabajo paciente, la virtud del orden, la convicción indestructible de que sin la primera palada no se eleva la montaña" (72); los personajes de su novela carecen de estos rasgos, mas no por atavismo de raza, como pretendía Argerich, sino porque el entorno al que son sometidos no los promueve.

Tres años antes de la publicación de El conventillo, Pascarella publica su Ensayo de psicología obrera argentina, el cual está incluido en una colección de artículos titulada La guerra europea y las industrias nacionales. En este ensayo el autor argentino propone que el origen del proletariado urbano no es la inmigración (supuestamente menor) europea sino la aparición del capitalismo. En este sentido, personajes como los Gómez Salustio personifican la consecuencia principal de este sistema económico: el consumismo desmesurado. El matrimonio está obsesionado con las modas y usos sociales franceses, con la higiene y con la ciencia médica. Consumen sin mesura, incluyendo a los seres humanos

\footnotetext{
132 Por ejemplo, Don Giovanni y doña Francisca, una de las parejas más estables y mejor acomodadas del conventillo, no pueden tener hijos. Por otro lado, don Esteban y su esposa, descritos como los inmigrantes más acriollados de la casa de vecindad (44), logran tener un hijo después de 15 años; no obstante, es un niño raquítico y de aspecto enfermizo. En contraposición, la Paisa, la única argentina que habita en la casa de inquilinato, sí tiene "la mar de hijos de toda laya y catadura" (25).
} 
que tienen empleados. ${ }^{133}$ En este sentido resulta significativo que su hijo consuma, sin consideración para con el otro bebé, la leche de Ana María que es, a su vez, tratada como un animal y no como una persona. Pascarella denuncia así la voluntad de las élites de mantener su posición y privilegios a punta de injusticias sociales extremas. A su modo de ver, esta relación entre explotadores y explotados forma parte de "un sistema perfectible en el cual todos los matices están libremente al alcance de todos" (72). El conventillo no plantea una crítica al inmigrante y sus modos de actuar sino más bien un cuestionamiento a rasgos citadinos como el materialismo y el culto al dinero y los peligros que estos suponen para una sociedad, como la argentina a principios del siglo XX, que aún no había logrado consolidar los valores nacionales y que con la modernidad corría el peligro de hacerlo sobre bases equivocadas (Torres-Pou, “Ciudad e inmigración” 275-276).

\section{Conclusión: el orden urbano y el sistema punitivo}

La criminología positivista fue uno de los discursos de la modernidad utilizados por las élites latinoamericanas a finales del siglo XIX y principios del XX como método para dar crédito a la prolongación de la estructura social piramidal de la Colonia en la que el escaño social ocupado estaba determinado desde el nacimiento por el origen de la persona, el color de su piel y el trabajo que desempeñaba. Este determinismo definía también cuáles espacios urbanos podía ocupar y frecuentar cada clase. Ángel de Campo y Luis Pascarella hacen uso en sus respectivas novelas de ese discurso criminológico; no obstante, y como he demostrado a lo largo de este capítulo, lo utilizan no para justificar el sistema sino para ponerlo en evidencia.

\footnotetext{
${ }^{133}$ Don Pascuale peca de lo mismo. La voz narrativa señala que valora a sus inquilinos de la siguiente manera: "Los cuartos, los trastos y las personas se confundían en un solo montón, en una sola entidad productora de un determinado número de pesos mensuales. El mes que alguna máquina fallaba, a la calle (...) (16).
} 
La dicotomía civilización/ciudad vs. barbarie/campo comenzó a perder su carácter maniqueo en las últimas décadas del siglo XIX. La urbe se dejó de concebir como espacio único civilizado y civilizador y se desdobló en el imaginario finisecular en dos: la ciudad civilizada/moderna y la ciudad bárbara/atrasada. Esta nueva conceptualización nos ha acompañado incluso hasta el siglo XXI. Con estos cambios apareció una nueva necesidad: trazar fronteras dentro de la misma urbe, nuevos límites geográficos entre la civilización y la barbarie para clasificar y ordenar a los habitantes de "ambas ciudades". Así la modernidad en Latinoamérica entrecruzó el urbanismo con los sistemas punitivos y de vigilancia.

Michel Foucault argumenta que la prisión, en cuanto espacio destinado para la reclusión de individuos problemáticos, es mucho anterior a su uso como castigo dentro del sistema punitivo moderno:

La forma-prisión prexiste a su utilización sistemática en las leyes penales. Se ha constituido en el exterior del aparato judicial, cuando se elaboraron, a través de todo el cuerpo social, los procedimientos para repartir a los individuos, fijarlos y distribuirlos espacialmente, clasificarlos, obtener de ellos el máximo de tiempo y el máximo de fuerzas, educar su cuerpo, codificar su comportamiento continuo, mantenerlos en una visibilidad sin lagunas, formar en torno a ellos todo un aparato de observación, de registro y de notaciones, construir sobre ellos un saber que se acumula y se centraliza. (Vigilar y castigar 233)

Siguiendo estos lineamientos, y como se desprende del análisis presentado, tanto los suburbios urbanos como las casas de vecindad constituyeron a finales del siglo XIX 
espacios de aislamiento de la otredad citadina. Eran prisiones sin ser cárceles oficiales y sus habitantes delincuentes a pesar de que no hubiesen quebrantado la ley. Al respecto, Ivette Orijel señala que el discurso de la modernidad creó estereotipos de las clases populares citadinas y los colocó en el escaparate del recelo: todos eran sospechosos de ser criminales en potencia (234). Con La rumba y El conventillo, De Campo y Pascarella no solo denuncian un sistema social instaurado en desigualdades profundas sino también un organizado modelo de exclusión y represión territorial basado en el trazado urbano de la ciudad moderna. En este sentido, la modernización de las capitales en Latinoamérica fue un fenómeno predominantemente elitista.

Javier Lasarte propone que uno de los logros de la escritura costumbrista fue la capacidad de transfigurar espacios físicos de la ciudad tachados de indecoroso en objetos culturales (181). Lasarte se refiere aquí a cuadros como El mercado de Nicanor Bolet Peraza del cual hablé en el capítulo I. A mi modo de ver, De Campo y Pascarella hacen lo mismo con los suburbios y las casas de vecindad al visibilizar y rescatar los espacios subalternos y sus moradores que también, a despecho de los intelectuales y políticos del momento, formaban parte tanto de las capitales como de la modernidad en Latinoamericana. 


\section{CONCLUSIONES}

Charles Baudelaire, el poeta de París (o más bien el poeta del tránsito a la París moderna), señala: “Le vieux Paris n'est plus (la forme d'une ville /Change plus vite, hélas! que le coeur d'un mortel)" (123). A partir de la segunda mitad del siglo XIX, las capitales latinoamericanas siguieron los pasos de la francesa en el vórtice vertiginoso de la velocidad (y a veces violencia) de los cambios arquitectónicos, económicos, sociales, culturales, etc.

que la modernización urbana impuso. Por esta razón, y como plantea Ángel Rama, padecieron también del desarraigo que suponía la transmutación de la ciudad como espacio encargado de objetivar la permanencia del individuo dentro de su entorno (95). Cristopher Conway afirma que el siglo XIX latinoamericano fue la era de la ciudad (23); yo agregaría que, y quizás por esta misma razón, fue el siglo de la incertidumbre. La narrativa de ciudad de finales del siglo XIX y principios del XX fue producto y espejo de esta situación.

Con respecto a la presencia de la ciudad en la literatura decimonónica, Burton Pike asevera:

Over the course of the nineteenth century the representation of the city in European and American literature gradually underwent two important shifts in emphasis. One was a movement from stasis to flux: The institutions of the city, its physical monuments and social classes, were portrayed less and less as elements perceptually fixed in relation to each other and more and more as a succession of fluid and unpredictable juxtapositions. (27)

Lo mismo sucedió en la literatura latinoamericana, la ciudad dejó de ser telón de fondo estático para convertirse en foco de la narración, en partícipe activa de la formación y acciones de los personajes e, incluso, en protagonista. En Latinoamérica hay novela 
urbana desde el siglo XIX; sin embargo, este género ha sido estudiado de forma casi exclusiva como un fenómeno de los siglos XX y XXI. Las novelas de ciudad de finales del siglo XIX y principios del XX o han caído en los anaqueles del olvido (tal es el caso de Todo un pueblo, La rumba y El conventillo) o su carácter de novela urbana ha sido omitido por los estudios literarios (como ha sucedido con La gran aldea, Ídolos rotos y Santa). Mi disertación identifica y rescata seis novelas urbanas finiseculares y analiza la valoración de la modernización (y de otros conceptos a ella relacionados como civilización, barbarie, progreso, modernidad y ciudadanía) a través de la imagen literaria de la ciudad que se presenta en los textos.

La publicación en 1845 de Facundo de Domingo Faustino Sarmiento definió la supuesta relación intrínseca entre ciudad y civilización. A esta posición se le sumó más adelante la idea de que solo lo civilización posibilitaría la modernización. El campo, por contraposición, se concebía como bárbaro y atrasado. Si bien es cierto que la independencia de la mayoría de los países de Latinoamérica se concretó en las primeras décadas del siglo XIX, la formación y consolidación nacional (si es que en algún momento la ha habido) no llegaría sino décadas más tarde. La ciudad jugó un papel fundamental (desde el punto de vista histórico y cultural) en este proceso pues encarnaba la civilización desde la cual se debía conceptualizar y establecer las repúblicas modernas. No es de extrañar entonces que la urbe fuera la protagonista indiscutible de diversos géneros literarios. No obstante, y quizás irónicamente, la imagen del espacio urbano que se presentó en la literatura decimonónica latinoamericana con frecuencia cuestionó (e incluso desafió) la posición de la ciudad como espacio moderno, civilizado y civilizador, así como la efectividad de los planes modernizadores de las élites liberales del momento. 
Mi investigación plantea al comienzo un análisis de la imagen de ciudad presentada en una selección de cuadros de costumbres latinoamericanos. Las cualidades estéticas de este género han sido cuestionadas con harta frecuencia y, por esta razón, su estudio ha sido menospreciado. Pese a esto, el cuadro de costumbres resulta de gran importancia en el contexto de esta disertación pues fue el género que le dio dimensión literaria a la ciudad por primera vez y, además, es el precursor de la novela en Latinoamérica. El cuadro de costumbres abrió en la literatura del continente las primeras líneas de cuestionamiento con respecto al espacio urbano, la modernización, el progreso, la tradición y la barbarie. Para algunos costumbristas la ciudad oscilaba entre ser el paradigma de la modernidad o el vacío de la civilización a la que se aspiraba; para otros, la urbe fue el campo de batalla entre los valores irreconciliables de la modernidad (exportados de Francia y/o Inglaterra) y los de la tradición hispanista (heredados de la época colonial).

El género costumbrista fue de praxis nacionalizadora (Soriano y Martínez Pinzón 11); no obstante, no hubo consenso entre los escritores en cómo debía ser la república moderna y sus habitantes. Tampoco lo hubo entre los políticos e intelectuales del momento. Según Julio Ramos, esta inestabilidad se originó en la dificultad de producir e interpretar textos literarios en una sociedad propensa a las fluctuaciones de valores. La ciencia, el progreso y la modernidad no lograron asimilarse con la solidez de los valores coloniales de antaño (21). La postura crítica del cuadro de costumbres ante la modernización y el espacio urbano fue retomada y ahondada por los novelistas de ciudad de finales del siglo XIX y principios del XX.

En los capítulos II, III y IV abordo el análisis de la representación de la ciudad y de la vida urbana presentado en seis novelas urbanas escritas en México, Argentina y 
Venezuela entre 1880 y 1920. La selección responde, por un lado, a la producción y fecha de publicación de la mayoría de los textos encontrados y, por otro, a las décadas cumbre de la modernización en las capitales latinoamericanas. Estudiar (y escribir sobre) la ciudad, sin importar la época, implica mucho más que un compendio de sus espacios físicos (tema que sí atañe a la historia del urbanismo, por ejemplo). En el caso de las novelas de ciudad finiseculares, los espacios y obras arquitectónicas aparecen con frecuencia debido a la estética realista/naturalista, sumamente popular en la época, a la que se circunscriben todas las novelas estudiadas. No obstante, mi investigación no se concentra de manera exclusiva en la reproducción fidedigna de las renovaciones urbanas. Con respecto a la literatura urbana del XIX, Robert Alter señala:

Focus has been not on an objective entity called the modern city which is somehow "reflected" in the novel but rather on a certain range of experience, much of it quite distinctive in nature, that is generated by the new metropolises and which innovative writers found compelling means of expression. (141)

Blanche Housman Gelfant, por su parte, afirma que en las novelas de ciudad el entramado urbano se crea a partir de tres elementos: "the physical facts of the scene, the aesthetic impresssion and the urban atmosphere" (15). Tomando en cuenta estos postulados, mi análisis de las novelas seleccionadas - La gran aldea, Todo un pueblo, Ídolos rotos, Santa, La rumba y El conventillo- se concentra en la relación que se establece entre los espacios físicos de la ciudad y temas como: el constante conflicto entre la definición de la civilización y la barbarie, la ambivalencia en la valoración de la moral y las costumbres modernas exportadas de Francia e Inglaterra frente a las de origen hispano 
heredadas de la Colonia, las pugnas y alianzas entre la nueva burguesía y la antigua clase patricia, la compulsión de las élites urbanas por los modales y el decoro, la idea de la ciudad capital como una especie de sinécdoque de la nación, la discusión de la ciudadanía y la formación de los ciudadanos, la disputa acerca de la efectividad de los planes liberales de modernización (y de quienes debían llevarlos a cabo), el temor de las clases dirigentes de perder su espacio de poder ante la otredad citadina y los mecanismos modernos de control de la población subalterna.

Más que el monumentalismo de la modernidad, estos textos exponen la degradación y el fracaso del mito moderno de la ciudad como espacio civilizado y civilizador y, a la vez, ponen en evidencia las contradicciones e incongruencias ideológicas sobre las que se asentó la modernidad en Latinoamérica ya que se pretendió definir lo nacional, lo propio, a partir de paradigmas europeos y, al mismo tiempo, alejarse del bárbaro pasado colonial, pero conservar la pirámide social que de él se heredó y que mantenía a las clases subalternas oprimidas. ${ }^{134}$ La modernización de las ciudades no se presenta en estas novelas como un fenómeno democrático (como promulgaban los políticos del momento) sino como un proceso elitista, racista, misógino y xenófobo. De esta manera, mi investigación presenta una relectura de la imagen de la ciudad en el imaginario decimonónico, así como una revaluación del proceso de modernización de las capitales latinoamericanas el cual ha sido entendido por la historiografía tradicional como una transformación deseada y predominantemente positiva.

\footnotetext{
${ }^{134}$ En este sentido, el título de la novela de Manuel Díaz Rodríguez, Ídolos rotos, es el más significativo pues alude de manera directa a este fracaso.
} 
Asimismo, mi disertación avanza los estudios sobre la novela de ciudad, un género que salvo ciertas excepciones y, a pesar de existir un corpus significativo, no ha sido lo suficientemente abordado dentro del contexto decimonónico. Como se desprende de mi análisis, estos textos arrojan información significativa sobre la formulación de las repúblicas latinoamericanas y su paso a la modernidad. Mi investigación ofrece además un diálogo novedoso, si bien no exhaustivo, entre los cuadros de costumbres y novelas de ciudad de diferentes países y la representación de la urbe que en ellos aparece, así como las tensiones y preocupaciones que estas imágenes generan y exponen. De esta manera establezco conexiones literarias transnacionales sobre la narrativa urbana y el proceso de modernización de distintos países.

Gisela Heffes señala que la realidad urbana trasciende el espacio material de la ciudad:

La ciudad consiste simultáneamente tanto en un lugar donde vivir como en un lugar imaginado. Así como las ciudades están formadas por parques y casas, calles, autopistas y señales de tránsito, se encuentran a su vez formadas por imágenes. Están las imágenes que incluyen aquellos mapas que se inventan y ordenan la ciudad, pero también aquellas que aparecen en las narraciones ficcionales, en las canciones, en las películas y en los medios de comunicación como la radio y la televisión (...) En consecuencia, la ciudad programada para funcionar y diseñada en una grilla excede sus límites, multiplicando sus dimensiones a través de ficciones individuales y colectivas. (23) 
En este sentido, mi investigación no solo contribuye con los estudios literarios sino también con los estudios sobre la ciudad en Latinoamérica que con frecuencia han dejado de lado a la ciudad literaria a pesar de que esta forma parte de la urbe misma.

Pretender contener en un solo trabajo el estudio total de la ciudad literaria decimonónica en Latinoamérica resulta inalcanzable. En primer lugar, la imagen de la ciudad en la literatura es fragmentada y responde a la estética de lo irrepresentable. Las dimensiones y complejidad cultural de la urbe real la hacen inabarcable (Pike ix, Strauss 8) por lo que su representación pictórica, fotográfica, literaria, etc. es siempre un fragmento (a pesar de que en ocasiones se pretenda lo contrario). Por otro lado, la textualización, tanto de la realidad en general como de la ciudad en particular, constituye, inclusive en la estética realista que pretende ser objetiva, un constructo literario permeado, de manera consciente o inconsciente, por la cultura, ideología y/o posición de quien escribe. Richard Lehan señala al respecto: "Textualizing the city creates its own reality, (...) Ideologically charged, each construct carries an agenda (...)" (291). De allí que se incluyan ciertos espacios y habitantes en la representación urbana, pero se excluyan otros. Existen tantas aproximaciones a la ciudad como individuos que la vivan, piensen y/o representen. Por estas razones, considero que la línea de investigación que planteo en este trabajo puede ampliarse para incluir cuadros de costumbres y/o novelas de ciudad producidas en otros países no contemplados en este trabajo, así como otros géneros de la época, como crónica cuento o tradiciones, que también utilizaron la ciudad como su centro narrativo.

Silvia Spitta asevera que el pensamiento latinoamericano ha privilegiado, incluso desde la Conquista, a la ciudad y lo urbano (es decir, al espacio) frente a Europa o Estados Unidos (a los que ha pretendido emular) que le han dado más prominencia al tiempo al 
favorecer el devenir histórico (7). ${ }^{135}$ En este sentido, la ciudad es un elemento fundamental en el imaginario del continente cuestión que explica el interés que ha despertado y sigue despertando en los estudios latinoamericanos. A pesar de que en el 2020 la modernización urbana en Latinoamérica puede parecer en fenómeno lejano y quizás anacrónico; aún se padecen en las ciudades los desbarajustes de haber atravesado una modernización que se enfocó en lo ornamental en detrimento de lo social y/o lo económico. Solo mirando hacia atrás podremos repensar estos procesos y sus consecuencias.

${ }^{135}$ Esto representa una diferencia básica entre el desarrollo urbano de Latinoamérica y el de Europa. En América Latina se le adjudicó la tarea civilizadora a la ciudad incluso antes de que esta creciera y se convirtiera en una urbe como tal. Durante la Colonia, los españoles fundaron ciudades (en torno a las cuales se aglomeraron) con la finalidad de cristianizar y civilizar a los territorios e indios conquistados; no obstante, en la mayoría de los casos, no lograron su cometido. 


\section{BIBLIOGRAFÍA}

Acosta de Samper, Soledad. "Mi madrina. Recuerdos de Santafé". Novelas y cuadros de la vida Sur-Americana, de Soledad Acosta de Samper, Imprenta de Eug. Vanderhaeghen,1869, pág. 411-422.

Alberdi, Juan Bautista. Bases y puntos de partida para la organización política de la República de Argentina. La Cultura Argentina, 1915.

Alcott, Louis May. Little Women. Grosset \& Dunlap Publishers, 1911.

Almandoz, Arturo. La ciudad en el imaginario venezolano: del tiempo de Maricastaña a la manifestación de los techos rojos. Fundación para la Cultura Urbana, 2002.

Alter, Robert. Imagined cities: urban experience and the language of the novel. Yale U P, 2005.

Álvarez, Alexandra. "Ídolos rotos de Manuel Díaz Rodríguez: una tropical 'novela de artista'”. Nueva revista de filología hispánica, vol. 41, núm. 1, 1993, pág. 293-331.

Aragón Rosano, Flavia. "Los Goncourt en España". La cultura del otro: español en Francia, francés en España, coordinado por Manuel Bruña Cuevas, María de Gracia Caballos, Inmaculada Ilanes, Carmen Ramírez y Anna Reventós, Universidad de Sevilla, 2006, pág. 309-319.

Arenas Saavedra, Ana. "El discurso novelesco de Todo un pueblo de Miguel Eduardo Pardo: la búsqueda de una conciencia nacional". Revista de Literatura Hispanoamericana, núm. 35, 1997, pág. 75.86.

Argerich, Antonio. Inocentes o culpables: novela naturalista. Imprenta del Courrier de la Plata, 1884.

Armus, Diego. La ciudad impura. Salud, tuberculosis y cultura en Buenos Aires, 18701950. Edhasa, 2007.

Azevedo, Aluísio. O cortiço. Martins, 1959.

Bachelard, Gaston. La poética del espacio. Fondo de Cultura Económico, 1994.

Bakhtin, Mikhail. "The Bildungsroman and Its Significance in the History of Realism (Toward a Historical Typology of the Novel)". Speech Genres and other late Essays, de Mikhail Bakhtin, traducido por Vern W. McGee, editado por Caryl Emerson y Michael Holquist, U Texas P, 1986, pág. 10-59.

Balbuena, Bernardo. La grandeza mexicana. Biblioteca Nueva, 2013. 
Barrios, Alba Lía. Primer costumbrismo venezolano. Ediciones La Casa de Bello, 1994.

Barroeta Lara, Julio. Los caraqueños vistos por los costumbristas del siglo XIX. Fundarte, 1983.

Baudelaire, Charles. "Le Cygne". Le fleurs du mal de Charles Baudelaire, Édition du grouppe, 2003, pág. 123-124.

Bergero, Adriana. Intersecting Tango. Cultural Geographies of Buenos Aires, 1900-1930. U of Pittsburgh P, 2008.

Blasi, Alberto. "La gran aldea y su contexto histórico: de la ciudad aristocrática a la metrópolis". Río de la Plata, enero de 1991, pág. 167-176.

Bohórquez, Douglas. "Para una lectura del costumbrismo en Venezuela". Revista de Literatura Hispanoamericana, núm. 39, 1999, pág. 41-60.

Bolet Perza, Nicanor. "El mercado". Antología de costumbristas venezolanos del siglo XIX, compilado por Mariano Picón Salas, Monte Ávila Editores, 1980, pág. 210-240.

Buckley, Jerome Hamilton. Season of youth. Harvard U P, 1974.

Buck-Morrs, Susan. "The Flâneur, the Sandwichman and the Whore: The Politics of Loitering”. New German Critique, núm. 38, 1986, pág. 99-140.

Büschges, Christian. "Linaje, patrimonio y prestigio. La nobleza titulada de la ciudad de Quito en el siglo XVIII", Anuario de Estudios Americanos, vol. 56, núm. 1, 1999, pág. 123-145.

Cabello de Carbonera, Mercedes. Blanca Sol (Novela social). Librería del Universo de C. Prince, 1889.

Cagigal, Juan Manuel. "Contratiempos de un viajero". Antología de costumbristas venezolanos del siglo XIX, compilado por Mariano Picón Salas, Monte Ávila Editores, 1980, pág. 14-27.

Calcaño, José Antonio. La ciudad y su música. Tipografía Vargas, 1958.

Cambaceres, Eugenio. Sin rumbo. Losada, 2009.

Cantero, M. Ángeles. "De "perfecta casada" a "ángel del hogar" o la construcción del arquetipo femenino en el XIX". Tonos: revista electrónica de estudios filológicos, núm. 14, dic. 2007, s/p. 
Carballo, Alejandra Karina. Raza, clase y género en la representación de la mujer inmigrante y extranjera en Argentina (1880-1930). 2006. Florida State University, tesis doctoral.

Carreño, Manuel Antonio. Manual de urbanidad y buenas maneras: de consulta indispensable para niños, jóvenes y adultos. Panamericana, 1993.

Castellanos, Rafael Ramón. Guzmán Blanco en la intimidad. Publicaciones Seleven, 1980.

Castells-Quintana, David. "América Latina es la región más urbanizada del mundo en desarrollo.” El Observador, 15 nov. 2017, www.elobservador.com.uy/nota/americalatina-es-la-region-mas-urbanizada-del-mundo-en-desarrollo-20171116500.

Consultado el 6 de agosto del 2020.

Castro Urioste, José. "Utopía y transgresión: El imaginario nacional en la obra de Rómulo Gallegos”. Hispanic Journal, vol. 17, núm. 2, 1996, pág. 329-344.

Cervantes, Miguel de. Don Quijote de la Mancha, Real Academia Española, 2004.

Céspedes del Castillo, Guillermo. "La sociedad colonial americana en los siglos XVI y XVII". Historia social y económica de España y América, editado por Jaime Vicens Vives, Editorial Vicens Vives, 1961, pág.

Conway, Christopher. Nineteenth-Century Spanish America: A Cultural History. Vanderbilt U P, 2015.

Cornejo Polar, Jorge. Sobre Segura. Universidad Nacional de San Agustín, 1970.

Cortés Guerrero, José David. "Las costumbres y los tipos como interpretaciones de la historia: Los mexicanos pintados por sí mismos y el Museo de cuadros de costumbres". Estudios de literatura colombiana, núm. 33, 2013, pág. 13-36.

Cortés-Rocca, Paola. "La ciudad bajo los ojos del modernismo". Pensar el siglo XIX desde el siglo XXI. Nuevas miradas y lecturas, compilado y editado por Ana Peluffo, Editorial Contracorriente, 2012, pág. 169-192.

Cuvardic Garcia, Dorde. "La flaneuse en la historia de la cultura occidental". Revista de filología y lingüistica de la Universidad de Costa Rica, vol. 37, núm. 1, 2011, pág. 68-95.

Darío, Rubén. Autobiografía. Mondadori, 1990.

---. "El rey burgués". Antología de cuentos hispanoamericanos, compilado por Mario Rodríguez Hernández, Editorial Universitaria, 2013, pág. 109-114. 
D’Alessandro Bello, María Elena. La novela urbana en Latinoamérica durante los años 1945-1959. Fundación Celarg, 1992.

De Campo, Ángel. La rumba. Instituto Latinoamericano de la Comunicación Educativa, 2009.

Dennis, Richard. Cities in modernity: Representations and Productions of Metropolitan Space, 1840-1930. Cambridge UP, 2008.

Díaz Rodríguez, Manuel. Confidencias de Psiquis. Tip. El Cojo, 1896.

---. Cuentos de color. Ediciones Nueva Cádiz, 1953.

---. Ídolos rotos. Imprenta Española de Garnier Hermanos, 1901.

---. Sangre Patricia. Tipografía J. M. Herrera Irigoyen \& CA., 1902.

Díaz Seijas, Pedro. "Hacia un concepto del costumbrismo en Venezuela". Antología de costumbristas venezolanos del siglo XIX, compilado por Mariano Picón Salas, Monte Ávila Editores, 1980, pág. 423-435.

El Zulia Ilustrado, reproducción facsimilar, Fundación Belloso. Tipografía Vargas S. A., Caracas, Venezuela, 1965.

Epple, Juan Armando. "De Santa a Mariana: la Ciudad de México como utopía traicionada". Revista chilena de literatura, núm. 54, 1999, pág. 31-42.

Fernández de Lizardi, José Joaquín. El periquillo sarniento. Maucci Hermanos, 1901.

Foster, David William. "La gran aldea as Ideological Document". Hispanic Review, vol. 56, núm. 1, 1988, pág. 73-87.

Foucault, Michel. La vida de los hombres infames. Ensayos sobre desviación y dominación. Ediciones de la Piqueta, 1990.

---. "Of other Spaces", traducido por Jay Miskowiec. Diacritics, vol.16, núm.1, 1986, pág. 22-27.

---. Vigilar y castigar Nacimiento de la prisión. Siglo Veintiuno Editores, 2003.

Fuentes, Manuel Atanasio. Lima, apuntes históricos, descriptivos, estadísticos y de costumbres. Librería de Firmin Didot, 1867.

Fuguet, Alberto y Gómez, Sergio. "Presentación al país McOndo". McOndo, editado por Alberto Fuguet y Sergio Gómez, Mondadori, 1996, pág. 11-20. 
Galindo Cruz, Diana. "El museo (en el) impreso. Un acercamiento al Museo de cuadros de costumbres y variedades". Cuadernos de música, artes visuales y artes escénicas, vol. 2, núm. 10, 2015, pág. 107-130.

Gallegos, Rómulo. Doña Bárbara. Panapo, 1999.

Gamboa, Federico. Santa. Talleres Araluce, 1903.

García Mérau, Martín. Inocentes o culpables/ 1885. En: https://web.archive.org/web/20150512053030/http://www.biblioteca.clarin.com/p bda/ensayo/inocentes/b-605033.htm . Consultado el 19 de agosto del 2020.

---. Libros y autores. F. Lajouane, 1886.

Goldgel, Víctor. Cuando lo nuevo conquistó América: prensa, moda y literatura en el siglo XIX. Siglo Veintiuno Editores, 2013.

Gomes, Miriam. "Las comunidades negras en la argentina: Estrategias de inserción y mecanismos de invisibilización". Afroargentinos hoy: Invisibilización, identidad y movilización social, compilado por Martha M. Maffia y Gladys Lechini, CONICET y Facultad de Ciencias Naturales y Museo, 2009, s/p.

Goncourt, Edmond de. La fille Élisa. G. Charpentier, Éditeur, 1877.

González Stephan, Beatriz. "Modernización y disciplinamiento. La formación del ciudadano: del espacio público y privado". Esplendores y miserias del siglo XIX: cultura y sociedad en América Latina, compilado por Beatriz González Stephan, Javier Lasarte, Graciela Montaldo y María Julia Daroqui, Monte Ávila Editores, 1995, pág. 431-455.

---. "Todo un pueblo: Modernismo/modernidad: La crisis finisecular en Venezuela. Escritura, vol. 8, 1983, pág. 251-272.

Gordillo Restrepo, Andrés. "El Mosaico (1858-1872): nacionalismo, élites y cultura en la segunda mitad del siglo XIX”. Fronteras de la historia, núm. 8, 2003, pág. 19-63.

Gottmann, Jean. Megalopolis. The urbanized northeastern seaboard of the United States. The Twentieth Century Fund, 1961.

Griffin, Dustin. Satire: A Critical Reintroduction. U P of Kentucky. 1994.

Gutiérrez, Girardot. Rafael. Modernismo. Montesinos, 1983.

Gutiérrez Vergara, Ignacio. "Cachaco". Museo de cuadros de costumbres y variedades, Biblioteca El Mosaico, 1866, pág. 101-103. 
Heffes, Gisela. "Introducción”. Utopías urbanas geopolíticas del deseo en América Latina, editado por Gisela Heffes, Nexos y Diferencias, 2013, pág. 13-45.

Hernández, Tulio (comp). Ciudad, espacio público y cultura urbana. Fundación para la Cultura Urbana, 2010.

Hirsch, Marianne. "The Novel of Formation as Genre: Between Great Expectations and Lost Illusions”. Genre 12, núm. 3, 1979, pág 293-311.

Holmes, Amanda. City Fictions. Language, Body, and Spanish American Urban Space. Bucknell U P, 2007.

Housman Gelfant, Blanche. The American City Novel. U of Oklahoma P, 1970.

Ingraham, Christopher. "Americans say there is not much appeal to big-city living. Why so many of us live there? The Washington Post, 18 de diciembre del 2018, https://www.washingtonpost.com/business/2018/12/18/americans-say-theres-notmuch-appeal-big-city-living-why-do-so-many-us-live-there/. Consultado el 6 de agosto del 2020.

Jeffers, Thomas. Apprenticeships: The Bildungsroman from Goethe to Santayana. Palgrave, 2005.

Jofre, Álvaro Salvador. El impuro amor a las ciudades (Notas acerca de la literatura modernista y el espacio urbano). Fondo Editorial Casa de las Américas, 2002.

Kirkpatrick, Susan. "The Ideology of Costumbrismo". Ideologies and Literature, vol. 2, núm. 7, 1978, pág. 28-44.

Kristeva, Julia. Powers of Horrors. An Essay on Abjection. Columbia U P, 1982.

Kushigian, Julia. Reconstructing Childhood: Strategies of Reading for Culture and Gender in the Spanish American Bildungsroman. Bucknell U P, 2003.

Lara y Pardo, Luis. La prostitución en México. Librería de la V ${ }^{\mathrm{DA}}$ de CH. Bouret, 1908.

Lasarte, Javier. "Ciudadanías del costumbrismo en Venezuela". Revista Iberoamericana, núm. LXIII, 1997, pág. 175-184.

Lehan, Richard. The City in Literature: An Intellectual and Cultural History. U of California P, 1998.

Leys Stepan, Nancy. "The Hour of Eugenics" Race, Gender, and Nation in Latin America. Cornell U P, 1991. 
Llano, Fabián Andrés. "De escritores despreciables a escritores eximios: el poder de la escritura en Bogotá 1850-1886”. Esfera, vol. 1, núm. 2, 2011, pág. 21-40.

Lombroso, Cesare y Ferrero, G. La donna delinquente, la prostituta e la donna normale. Frateli Boca Editori, 1903.

López de Gómara, Francisco. Historia general de las Indias. Biblioteca Ayacucho, 2008.

López Gallego, Manuel. “Bildungsroman. Historias para crecer”. Tejuelo, núm. 18, 2013, pág. 62-75.

López, Lucio Vicente. La gran aldea: (costumbres bonaerenses). Imprenta de Martí Biedma, 1884.

Lummis, Charles. The Awakening of a Nation: Mexico of To-Day. Harper and Brothers, 1904.

Martel, Julián. La bolsa (Estudio social). Imprenta Artística Buenos Aires, 1898.

Martínez Pinzón, Felipe. "El costumbrismo cosmopolita: deuda, producción de pueblo y color local en el siglo XIX". Revisitar el costumbrismo: cosmopolitismo, pedagogías y modernización en Iberoamérica, editado por Kari Soriano Salkjelsvik y Felipe Martínez Pinzón, Peter Lang Edition, 2016, pág. 231-250.

---. Una cultura de invernadero: trópico y civilización en Colombia (1808-1928). Iberoamericana, 2016.

Massé, Patricia. "Realidad y actualidad de las prostitutas mexicanas fotografiadas en 1865”. Política y Cultura, núm. 6, primavera 1996, pág. 111-131.

Mata Gil, Milagros. "Los espacios alternos en la novela venezolana". Literatura venezolana hoy: historia nacional y presente urbano, editado por Karl Kohut, Universidad Católica de Eichstatt, 1999, pág. 213-226.

"Megalópolis cada vez mayores: así crecieron las ciudades más pobladas del mundo en el siglo XXI." Univision, 14 de enero del 2020, www.univision.com/noticias/trending/megalopolis-cada-vez-mayores-asicrecieron-las-ciudades-mas-pobladas-del-mundo-en-el-siglo-xxi-fotos. Consultado el 6 de agosto del 2020.

Mejía Corre, Clara. "La novela urbana en Colombia: reflexiones alrededor de su denominación”. Lingüistica y literatura, núm, 57, 2010, pág. 63-77.

Mejía Pavony, Germán Rodrigo. Los años del cambio: historia urbana de Bogotá 18201910. Centro Editorial Javeriano, 2000. 
Mèlich, Joan Carles. "La disolución del sujeto en las novelas de deformación". Ars Brevis, núm. 4, 1998, pág. 171-183.

Mendoza, Daniel. "Palmarote en Apure". Antología de costumbristas venezolanos del siglo XIX, compilado por Mariano Picón Salas, Monte Ávila Editores, 1980, pág. 144177

---. "Un llanero en la capital". Antología de costumbristas venezolanos del siglo XIX, compilado por Mariano Picón Salas, Monte Ávila Editores, 1980, pág. 91-107.

Mercer, Leigh. Urbanism and Urbanity. The Spanish Bourgeois Novel and Contemporary Customs (1845-1925). Bucknell U P, 2013.

Mesonero Romanos, Ramón de. Escenas matritenses. Imprenta y librería de D. Ignacio Boix, 1945.

Michelena, Carmen. "Algunos aspectos de la Caracas licenciosa en la transición hacia el siglo XX". Tierra firme: revista de historia y ciencias sociales, vol. XX, núm. 79, 2002, pág. 309-321.

Montalvo, Juan. Siete tratados. Imprenta de José Jacquin, 1882.

Mumford, Lewis. The City in History. Brace \& World, 1961.

Nordau, Max. Degeneration. Trad. George L. Mosse, U of Nebraska P, 1993.

Nuñez, Herminio. "Sobre el concepto de identidad latinoamericana". Cuadernos Americanos, 124 2008, págs. 181-199.

Ocantos, Carlos María. Quilito. Imprenta de La Nación, 1913.

Olea Franco. Rafael. "La modernidad de La rumba de Ángel de Campo. La rumba de Ángel de Campo, Novelas en tránsito, 2018, pág. 7-36.

Orijel, Ivette. "Discurso legal positivista. Criminalización de los grupos populares en México durante el porfiriato". Los grupos sociales en la modernización latinoamericana de entre siglos, editado por Fernando J. Remedi y Teresita Rodríguez Morales, Conicet, 2011, pág. 231-248.

Otero Luque, Frank. "La gran aldea (1884) de Lucio Vicente López: la ciudad de Buenos Aires como tropo literario". Argus, vol.4, núm. 14, 2014, s/p.

Pardo, Miguel Eduardo. Todo un pueblo. Monte Ávila Editores, 1998. 
Parsons, Deborah. Streetwalking the Metropolis. Woman, the City and Modernity. Oxford U P, 2000.

Pascarella, Luis. El conventillo (Costumbres bonaerenses). Tall. Gráficos "La Lectura", 1917.

---. La guerra europea y las industrias nacionales (necesidad de bastarse a símismos). Balcarce, 1914.

Pérez-Anzaldo, Guadalupe. "La representación del espacio urbano en consonancia con el sujeto transgresor femenino en Santa de Federico Gamboa". CiberLetras: revista de crítica literaria y de cultura, núm. 6, 2007, s/p.

Pérez Bonalde. Juan Antonio. "Vuelta a la patria". J.A. Pérez Bonalde, de Juan Antonio Pérez Bonalde, Colección Clásicos venezolanos, 1965, pág. 57-66.

Picón Febres, Gonzalo. La literatura venezolana del siglo XIX, 1946.

Picón Salas, Mariano. Estudios de literatura venezolana. Edime, 1961.

---. Formación y proceso de la literatura venezolana. Monte Ávila Editores, 1984.

---. "Prólogo". Antología de costumbristas venezolanos del siglo XIX, compilado por Mariano Picón Salas, Monte Ávila Editores, 1980, pág. 5-9.

Pike, Burton. The Image of the City in Modern Literature. Princeton U P, 1981.

Pineda, Carlos. "La rumba de Ángel Campo: la Ciudad de México del siglo XIX como imaginario sonoro". Literatura: teoría, historia, crítica, vol.8, núm. 2, 2016, pág. 105-126.

Plata, Francisco. "La voluntad de Azorín, novela de artista”. La nueva literatura hispánica, 2009, pág. 141-166.

Portes, Alejandro y John Walton. Urban Latin America: The Political Condition from Above and Below. U of Texas P, 1976.

Prendes Guardiola, Manuel. "Técnicas narrativas en La rumba de Ángel de Campo". Arrabal, núm. 4, 2002, pág. 149-160.

Quijada, Mónica. “¿Qué nación? Dinámicas y dicotomías de la nación en el imaginario hispanoamericano. Inventando la nación: Iberoamérica siglo XIX, coordinado por Antonio Annino Von Dusek y François-Xavier Guerra, Fondo de Cultura Económica, 2003, pág. 287-315. 
Rama, Ángel. La ciudad letrada. Ediciones del Norte, 1984.

Ramos, Julio. Divergent Modernities: Culture and Politics in Nineteenth-Century Latin America. Duke U P, 2001.

Rodó. José Enrique. Ariel. Cátedra, 2000.

Rojas y Cañas, Ramón. "Los apodos". Museo de limeñadas, de Ramón Rojas y Cañas, Universidad del Pacífico, 2005, pág. 112-113.

---. "Parte seria”. Museo de limeñadas, de Ramón Rojas y Cañas, Universidad del Pacífico, 2005, pág. 81.

---. "Saludos y despedidas". Museo de limeñadas, de Ramón Rojas y Cañas, Universidad del Pacífico, 2005, pág. 109-111.

---. "Una verdad como un templo". Museo de limeñadas, de Ramón Rojas y Cañas, Universidad del Pacífico, 2005, pág. 144-146.

Romero, José Luis. "La ciudad latinoamericana y los movimientos políticos". La urbanización en América Latina, compilado por Jorge Enrique Hardoy y Carlos Tobar, Editorial del Instituto, 1969, pág. 297-310.

---. Latinoamérica: las ciudades y las ideas. Editorial Universidad de Antioquía, 1999.

Romero-García, Manuel V. Peonía. Eduven, 2001.

Roumagnac, Carlos. Los criminales en México: Ensayo de psicología criminal. Tipografía El Fenix, 1904.

Ruiz, Bladimir. "La ciudad letrada y la creación de la cultura nacional: costumbrismo, prensa y nación." Chasqui: revista de literatura latinoamericana, vol. 33, núm. 2, 2004, pág.75-89.

Ruiz-Tresgallo, Silvia. "Parodia de las vidas de los santos y subversión del discurso místico en Santa de Federico Gamboa". Espéculo: Revista de Estudios Literarios, núm. 34, $2007, \mathrm{~s} / \mathrm{p}$.

Salas de Lecuna, Yolanda. Ideología y lenguaje en la narrativa de la modernidad. Monte Ávila Editores, 1990.

Samper, José María. "Dos palabras al lector". Novelas y cuadros de la vida Sur-Americana, de Soledad Acosta de Samper, Imprenta de Eug. Vanderhaeghen,1869, s/p. 
Sandoval, Adriana. Una Santa no tan santa. Universidad Nacional Autónoma de México, 2013.

Sarmiento, Domingo Faustino. Civilización y barbarie o Vida de Juan Facundo Quiroga. Biblioteca Ayacucho, 1985.

Schlickers, Sabine. "Santa, texto fundador ambivalente de la patria mexicana". Santa, Santa nuestra, editado por Rafael Olea Franco, Colegio de México, 2005, pág. 145158.

Schönfld, Christiane. Commodities of Desire: The Prostitute in Modern German Literature. Camden House, 2000.

Segura, Manuel Ascencio. "El té y la mazamorra". Obras completas, tomo 2, de Manuel Ascencio Segura, Universidad San Martín de Porres, 2005, pág. 603-606.

Semprum, Jesús. Crítica literaria, Fondo Editorial de Autores y temas Zulianos, 1981.

Seret, Roberta. Voyage into Creativity: The Modern Künstlerroman. Peter Lang, 1992.

Silva Beauregard, Paulette. "La narrativa venezolana en la época del Modernismo". Revista Chilena de Literatura, núm. 40, noviembre de 1992, pág. 41-56.

Silva, Ricardo. "Tres visitas". Artículos de costumbres, de Ricardo Silva, Imprenta de Silvestre y Ca., 1886, pág. 47-59.

Sommer, Doris. Ficciones fundacionales: las novelas fundacionales de América Latina. Fondo de Cultura Económica, 2004.

Soriano Salkjelsvik, Kari y Felipe Martínez-Pinzón. "Revisitar el costumbrismo: cosmopolitismo, pedagogías y modernización en Iberoamérica". Revisitar el costumbrismo: cosmopolitismo, pedagogías y modernización en Iberoamérica, editado por Kari Soriano Salkjelsvik y Felipe Martínez Pinzón, Peter Lang Edition, 2016, pág. 7-25.

Spicer-Escalante, Juan Pablo. "La Argentina decimonónica: la reproducción, los valores sociales, y el proyecto de nación en La gran aldea (1884) de Lucio Vicente López". Excavatio: Emile Zola and Naturalism, vol. 16, núm.1-2, 2002, pág. 326-42.

Spitta, Silvia. "Prefacio: más allá de la ciudad letrada". Más allá de la ciudad letrada: crónicas y espacios urbanos, editado por Boris Muñoz y Silvia Spitta. Iberoamericana, 2003, pág 7-23.

Strauss, Anselm. Images of the city. Transaction Books, 1976. 
Sunyer Martín, Pere. "La idea de ciudad en la literatura española del siglo XIX. Las ciudades españolas en la obra de Pedro Antonio de Alarcón (1833-1891)”. Scripta Vetera, vol. 50, 1992, s/p.

Terralla y Landa, Esteban. Lima por dentro y por fuera. Centro de Estudios Literarios Antonio Cornejo Polar y niversidad Mayor de San Marcos. 2011.

Torres-Pou, Joan. "Ciudad e inmigración: El conventillo de Luis Pascarella, novela de la transformación de Buenos Aires". Symposium: A Quarterly Journal in Modern Literatures, vol. 63, núm. 4, 2009, pág. 265-280.

---. "El intelectual y París. Crítica al europeísmo en dos novelas regeneracionistas caribeñas: Ídolos rotos y A fuego lento". Delaware Review of Latin American Studies, vol. 10, núm. 2, 2009, s/p.

---. "Intertextualidad en el discurso patriarcal burgués: referencias literarias en Martín Rivas de Alberto Blest Gana”. Explicación de textos literarios, vol.20, núm.1, 1991-1992, pág. 61-71.

---. "La ficción científica: fábula y mito en Santa de Federico Gamboa". Crítica Hispánica, vol.17, núm. 2, 1995, pág. 302-309.

---. “Técnicas y discurso criminológico en el Porfiriato: el caso de La rumba de Ángel Campo”. Iberoamericana, pág. 27-36.

Torres Tovar, Carlos Alberto. "La ciudad: espacio de inclusión y exclusión”. La ciudad: hábitat de diversidad y complejidad, compilado por Carlos Alberto Torres Tovar, Fernando Viviescas Monsalve y Edmundo Pérez Hernández, Universidad Nacional de Colombia, 2002, pág. 318-332.

Valero, Eva María. Lima en la tradición literaria del Perú: de la leyenda urbana a la disolución del mito. Edicions de la Universidad de Lleida, 2003.

Velayos, Emmanuel. "La sátira paratextual en la ciudad letrada limeña". Revista de crítica literaria latinoamericana, núm. 80, 2014, pág. 207-231.

Vergara y Vergara, José María. "El lenguaje de las casas". Museo de cuadros de costumbres y variedades, Biblioteca El Mosaico, 1866, pág. 392-401.

---. "Las tres tazas". Cuentos y relatos de la literatura colombiana, tomo I, compilado por Luz Mary Giraldo, Fondo de Cultura Económica, 2005, pág. 114-139.

---. "Prólogo". Museo de cuadros de costumbres y variedades, Biblioteca El Mosaico, 1866, pág. I-IV. 
Venegas, Jessica Shade. "Heterotopic Space and the Limits of Naturalist Discourse in Federico Gamboa's Santa". Symposium: A Quarterly Journal in Modern Literatures, vol.63, núm.4, pág. 251-264.

Vicuña Mackenna, Benjamín. La transformación de Santiago: Notas e indicaciones respetuosamente sometidas a la Ilustre Municipalidad, al Supremo Gobierno y al Congreso Nacional. Imprenta de la Librería del Mercurio, 1872.

Vila, Marco-Aurelio. Antecedentes coloniales de centros poblados de Venezuela. Universidad central de Venezuela, 1978.

Visbal Sierra, Ricardo. "La transformación del mundo colonial al republicano de la Nueva Granada en el cuadro de costumbres Las tres tazas, de José María Vergara y Vergara”. Independencias, Memoria y Futuro, Actas del XXXVIII Congreso Internacional del Instituto de Literatura Iberoamericana (IILI), Instituto Internacional de Literatura Iberoamericana, 2012, pág.1-13.

Watson, Maida. El cuadro de costumbres en el Perú decimonónico. Pontifica Universidad Católica del Perú, 1979.

Young Richard. "Buenos Aires and the Narration of Urban Spaces". Contemporary Latin American Studies, editado por Stephen Hart, Oxford UP, 2003, pág. 300-311.

Zarone, Giuseppe. Metafísica de la ciudad: encanto utópico y desencanto metropolitano. Universidad de Murcia, 1993.

Zola, Émile. Nana. Bibliothèque-Charpentier, 1906.

Zubiaurre, Maite. “Ciudades rotas, urbes mecánicas, metrópolis de cartón: Modernismo, vanguardia y poética de lo urbano en Manuel Díaz Rodríguez, Martín Adán y Arqueles Vela". La ciudad imaginaria, editado por Javier de Navascués, Iberoamericana, 2007, pág. 329-341. 
VITA

GABRIELA CAROLINA ESCOBAR RODRÍGUEZ

2007-2013 Licenciatura, Letras

Universidad Católica Andrés Bello

Caracas, Venezuela

2014 -2018 Ph.D. Student and Teaching Assistant

Department of Modern Languages

Florida International University

Miami, Florida

Summer 2018 Doctoral Evidence Acquisition Fellowship

2018 M.A., Spanish

Florida International University

Miami, Florida

2018 Best Teaching Assistant Award

Department of Modern Languages

Florida International University

Miami, Florida

2018-2020 Doctoral Candidate and Teaching Assistant

Department of Modern Languages

Florida International University

Miami, Florida

Summer/ Fall 2020 Dissertation Year Fellowship

\section{PUBLICATIONS AND PRESENTATIONS}

"Novelas de (de)formación: el caso de Ídolos rotos de Manuel Díaz Rodríguez y Santa de Federico Gamboa". 24th Southeast Conference of Foreign Languages, Literatures, and Film.

St. Petersburg, Fl. March 6-7, 2020.

"Entre la ansiedad y el cuestionamiento: cambios urbanos, nueva fauna citadina y crisis de valores en La gran aldea de Lucio Vicente López y Todo un pueblo de Miguel Eduardo Pardo". III Congreso International Perú XIX: Prensa y redes literarias en América Latina XIX (Miami Nov. 14-15, 2019 and Lima Nov. 27-28, 2019) organized by the Modern 
Languages Department and the Kimberly Green Latin American and Caribbean Center at Florida International University; the National University of San Marcos Research Office and Library; and the Research Group "Literatura y Arte: prensa, cultura visual y redes entre Europa y América Latina".

Miami, November 14- 15, 2019.

"Dialéctica de inclusión y exclusión: conflictos sociales, raciales e identitarios en Martín Rivas de Alberto Blest Gana y Sirena de Francisco Arriví". Cuba y Puerto Rico: Two Wings of One Bird? Organized by Cuban Research Institute at FIU. Miami, February 14$15,2019$.

"Retratos de Caracas: carencia, progreso y nostalgia en los cuadros de Juan Manuel Cagigal, Daniel Mendoza y Nicanor Bolet Peraza". Caracas y Miami: retratos literarios urbanos organized by Modern Languages Graduate Student Association at FIU.

Miami, October 29, 2018.

"Caracas vista por los costumbristas: espacio urbano, tradición, modernidad y progreso". LASA: Latin American Studies in a Globalized World.

Barcelona, May 23 - 26, 2018.

"Los pasos perdidos de Alejo Carpentier: Künstlerroman del artista latinoamericano moderno". SAMLA 89: High Art/ Low Art: Borders and Bounderies in Popular Culture.

Atlanta, November 3-5, 2017.

"Uso y crítica del discurso alienista finisecular en dos cuentos de Enrique Gómez Carrillo". LASA: Diálogo de sabere1. Escobar Rodríguez, Gabriela. s.

Lima, April 29- May 1, 2017.

"Aproximaciones a la renovación estética de fin de siglo en Venezuela: el caso de Julián de José Gil Fortoul”. Romance Notes, vol. 57, num. 3, 2017, pp.427-434.

"Aproximaciones a la renovación estética de fin de siglo en Venezuela: el caso de Julián de José Gil Fortoul”. SAMLA 88: Utopia/Dystopia: Whose Paradise Is It?

Jacksonville, November 4-6, 2016

"La visión de la ciudad como espacio evaluado y evaluador en los cuadros de costumbres venezolanos". Nineteenth-Century Latin American \& Spanish Literature International Conference at Florida International University.

Miami, November 20, 2015.

"Las ratas sí matan a otras ratas: subversión y cuestionamiento en El policía de las ratas de Roberto Bolaño" / "Rats do kill rats: Questioning and subversion in Police Rat by Roberto Bolaño". Aguas del Pozo / Waters of the Well, Editorial 5, September 2015. 